ANA PAULA DOS REIS

\title{
A DINÂMICA DA APRENDIZAGEM EM ARRANJOS PRODUTIVOS LOCAIS: UM ESTUDO DAS REDES DE CONHECIMENTO DAS PEQUENAS E MÉDIAS EMPRESAS DE SOFTWARE NA CONSTRUÇÃO DE SUAS CAPACITAÇÕES
}

Tese apresentada à Escola Politécnica da Universidade de São Paulo para obtenção do título de Doutor em Engenharia 
ANA PAULA DOS REIS

\section{A DINÂMICA DA APRENDIZAGEM EM ARRANJOS PRODUTIVOS LOCAIS: UM ESTUDO DAS REDES DE CONHECIMENTO DAS PEQUENAS E MÉDIAS EMPRESAS DE SOFTWARE NA CONSTRUÇÃO DE SUAS CAPACITAÇÕES}

Tese apresentada à Escola Politécnica da Universidade de São Paulo para obtenção do título de Doutor em Engenharia

Área de concentração:

Engenharia de Produção

Orientador:

Prof. Dr. João Amato Neto 
Este exemplar foi revisado e alterado em relação à versão original, sob responsabilidade única do autor e com a anuência de seu orientador.

São Paulo, 05 de junho de 2008

Assinatura do autor

Assinatura do orientador

FICHA CATALOGRÁFICA

Reis, Ana Paula dos

A dinâmica da aprendizagem em arranjos produtivos locais: um estudo das redes de conhecimento das pequenas e médias empresas de software na construção de suas capacitações / A.P. dos Reis. -- São Paulo, 2008.

$258 \mathrm{p}$.

Tese (Doutorado) - Escola Politécnica da Universidade de São Paulo. Departamento de Engenharia de Produção.

1. Clusters 2. Conhecimento 3. Aprendizagem 4. Redes de informação 5. Pequenas e médias empresas I. Universidade de São Paulo. Escola Politécnica. Departamento de Engenharia de Produção Il.t. 
À Fernando e Ana Lívia

Meus pais 


\section{AGRADECIMENTOS}

Talvez esta seja uma das partes mais importantes desta tese. Gostaria de dedicar muito tempo e espaço falando como foi válida a ajuda recebida de diversas pessoas que participaram direta ou indiretamente para a concretização deste projeto.

Porém, antes de tudo e de todos quero agradecer ao meu DEUS. Estou mais do que certa que sem Ele eu não teria tido forças para prosseguir.

Ao professor João Amato, meu orientador, pela orientação, confiança, motivação e paciência, que me fizeram admirá-lo como mestre e como pessoa.

Ao professor Mauro Spínola pelos contatos fornecidos e pela inestimável luz que concedeu à este trabalho.

À professora Sandra Ruffino pela ajuda e indispensáveis contribuições.

Ao Fernando... pelo sonho sonhado junto... pela presença na ausência... pelo amor dispensado.

Aos meus pais, pelo amor incondicional e por muito, muito e muito...

Ao Fer pela ajuda inestimável. À Mara pela torcida.

Ao Nando e à Andréia pelo uso, quase posse, do computador.

Ao Xande e à Pindu pelo carinho e orações.

Ao pessoal da FUMSOFT, Barbieri, Rosângela, Mauro Lamberti pela ajuda espontânea.

À Ana Liddy pela atenção e fundamental participação na pesquisa. 
Aos representantes das entidades (SOFTEX, Núcleo SOFTEX Campinas, Cenpra, CIATEC, ASSESPRO-BH, SEBRAE-BH, BLUSOFT, Instituto Gene, FURB, Instituto Euvaldo Lodi-SC, Univile-SC, Univale-SC, ACATE-SC) empresas e colaboradores entrevistados nesta tese, pelas valiosas informações.

Ao Kival Weber, Edvar Pêra Jr. Clênio Salviano, Jeziel Montanha, e professores, Carlos Bizotto, Marcelo Thiry, Marcelo Borba, Valéria Arriero Pereira, Everaldo Grahl pela atenção e tempo dispensados.

Ao grupo de GTI pelas contribuições.

À CAPES que financiou este trabalho.

Aos colegas da pós pela convivência. 


\section{RESUMO}

O objetivo principal desta pesquisa consiste em analisar os processos de aprendizagem das PME's de software. A habilidade para criar e utilizar conhecimento para gerar inovação em produtos e processos é um grande desafio imposto às empresas de qualquer tamanho ou porte. Nesse contexto, o desenvolvimento de competências e capacitações é um fator crucial para a obtenção e a sustentação de vantagens competitivas. As interações estruturadas de cooperação constituem-se um meio importante para ampliar e melhorar as condições de inserção na atividade produtiva, sobretudo das PME's. As redes de cooperação interorganizacionais têm sido apontadas como o novo locus da inovação. Por meio delas, o conhecimento, através dos processos de aprendizado, pode ser gerado de forma mais eficiente e rápida. A metodologia usada neste trabalho consistiu de uma pesquisa exploratória e qualitativa através do estudo de multicasos em três arranjos produtivos de software. Os resultados contribuem para o entendimento da dinâmica dos processos de aprendizado formal e informal, como as empresas se relacionam com as principais fontes externas de conhecimento local, como é a estrutura de governança local e os aspectos institucionais que influenciam os processos de aprendizado e difusão do conhecimento das PME's de software.

Palavras-chave: Aprendizagem. Conhecimento. Pequenas e Médias Empresas. Arranjos Produtivos Locais. 


\begin{abstract}
The main purpose of this research is to analyze the learning processes of SME's of software. The ability to create and use knowledge to generate innovation in products and processes is a great challenge to all companies, no matter their size. In this context, the development of abilities and qualifications is a crucial factor to attain and sustain competitive advantages. The cooperation through structuralized interactions is an important way to enlarge and to enhance the conditions of insertion in the activity of production. The inter-organizational networks of cooperation have been seen as the new locus of innovation. By using the learning process, they can generate knowledge faster and in a more efficient way. The methodology applied in this research consisted of an exploratory and qualitative research through a multicase study in three productive arrangements of software. The results contribute to the understanding of the dynamics of the processes of formal and informal learning, how the relationship is between companies and the main external sources of local knowledge, how the local governance is structured, as well as the institutional aspects that influence the learning processes and the diffusion of knowledge in SME's of software.
\end{abstract}

Keywords: Learning. Knowledge. Small and Medium Enterpreises. Local Productive Arrangements. 


\section{LISTA DE ILUSTRAÇÕES}

Figura 2.1 - Esquema para Plano de Ação Regional: modelo ideal teórico......... 48

Figura 2.2 - Tipologia de Redes de Empresas......................................... 68

Figura 2.3 - Mapa de Orientação Conceitual................................................. 75

Figura 2.4 - Espiral de criação do conhecimento........................................ 86

Figura 3.1 - Evolução do faturamento do mercado mundial de software

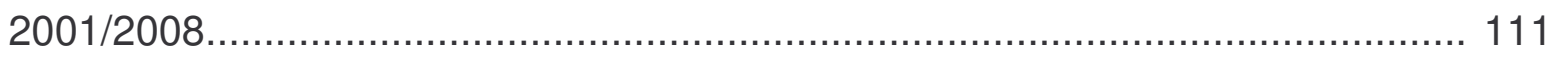

Figura 3.2 - Principais Indicadores do Mercado Brasileiro - 2005.................... 125

Figura 3.3 - Representação do Modelo CMM................................................... 132

Figura 3.4 - CMMI: quadro comparativo das características das

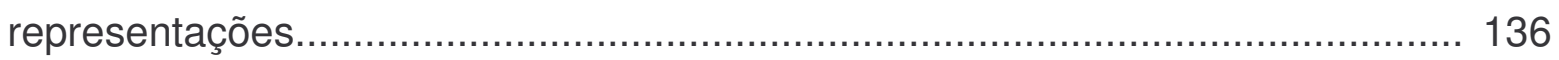

Figura 3.5 - Estrutura do Modelo MPS.BR.......................................... 142

Figura 3.6 - Estrutura do Modelo MR-MPS........................................... 143

Figura 3.7 - Processo de Avaliação MPS....................................................... 146 


\section{LISTA DE TABELAS}

Tabela 1.1 - Critérios de classificação de pesquisa............................................. 26

Tabela 2.1 - Sanções e Confiança...................................................................... 43

Tabela 2.2 - Formas de ações conjuntas em clusters de empresas.................... 45

Tabela 2.3 - Clusters: uma hierarquia de três conceitos...................................... 54

Tabela 2.4 - Tipologia de Sistemas Locais de Produção de Acordo com a sua Importância para a região................................................................................ 61

Tabela 2.5 - Síntese das Tipologias de Redes de Empresas............................. 80

Tabela 2.6 - Eixos e fatores para transmissão do conhecimento............................ 87

Tabela 2.7 - Síntese do referencial teórico................................................... 93

Tabela 3.1 - Comparação dos tipos de softwares de algumas categorias

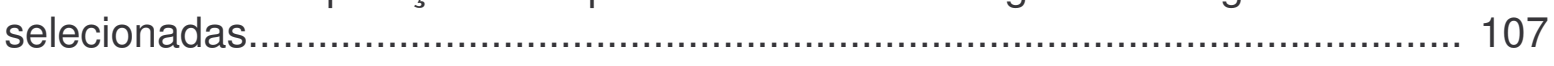

Tabela 3.2 - As dez maiores empresas de software produto.............................. 112

Tabela 3.3 - Principais formas de internacionalização das atividades de

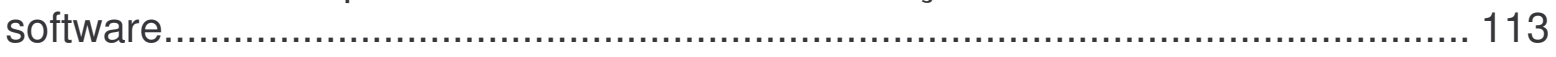

Tabela 3.4 - Mercado Mundial de Software e Serviços.......................................... 126

Tabela 3.5 - Resultados de Atributo de Processo do MR-MPS........................... 144

Tabela 3.6 - Níveis de Maturidade do MR-MPS e Atributos de Processo............. 145

Tabela 4.1 - Critério utilizado para classificação das empresas 160

Tabela 5.1 - Ações das instituições de coordenação do APL de Belo Horizonte.. 182

Tabela 5.2 - Aspectos relacionados à origem e trajetória dos APL's 199

Tabela 5.3 - Síntese das fontes de informações utilizadas no aprendizado das empresas em melhoria de processos de software............................................. 204

Tabela 5.4 - Principais vantagens e desvantagens do modelo cooperado de

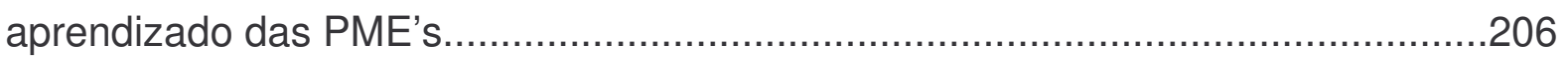

Tabela 5.5 - Síntese das principais questões de pesquisa da tese........................ 208 


\section{LISTA DE ABREVIATURAS E SIGLAS}

ABES

ADR

$A D R$

AMP

APG

MPS)

APL

$A Q U$

ARC

Assespro

BID

BNDES

CA

CMM

CMMI

CMU/SEI

CoP

DEP

DFP

DRE

ECT

FINEP

FUMIN

FURB

GCO

GPR

GQA

GQP

GRE
Associação Brasileira de Empresas de Software

Agência de Desenvolvimento Regional

Análise de Decisão e Resolução (processo MR-MPS)

Avaliação e Melhoria do Processo Organizacional (processo MR-MPS)

Adaptação do Processo para Gerência de Projeto (processo MR-

Arranjo Produtivo Local

Aquisição (processo MR-MPS)

Análise de Causas e Resolução (processo MR-MPS)

Associação das Empresas Brasileiras de Tecnologia da

Informação, Software e Internet

Banco Interamericano de Desenvolvimento

Banco Nacional de Desenvolvimento Econômico e Social

Consultores de Aquisição

Capability Maturity Model

Capability Maturity Model Integration

Carnegie Mellon University / Software Engineering Institute

Comunidade de Prática

Desempenho do Processo Organizacional (processo MR-MPS)

Definição do Processo Organizacional (processo MR-MPS)

Desenvolvimento de Requisitos (processo MR-MPS)

Economia dos Custos de Transação

Financiadora de Estudos e Projetos

Fundo Multilateral de Investimento

Fundação Universidade Regional de Blumenau

Gerência de Configuração (processo MR-MPS)

Gerência de Projeto (processo MR-MPS)

Garantia da Qualidade (processo MR-MPS)

Gerência Quantitativa do Projeto (processo MR-MPS)

Gerência de Requisitos (processo MR-MPS) 
GREMI

GRI

IA

IBM

IBM-PC

IEES

II

IIO

INMETRO

INPI

IOGES

IPI

ISO

ISO/IEC

ITP

MA-MPS

MCT

MED

MIT

MNC

MNE

MN-MPS

MPME

MPS

MPS.BR

MR-MPS

NEI

OCDE

PBQP Software

PITCE

PME'S

Prosoft
Groupement de Recherche Européen sur les Millieux Inovateurs Gerência de Riscos (processo MR-MPS)

Instituições Avaliadoras

International Business Machines

IBM - Personal Computer

International Electrotechnical Commission

Instituições Implementadoras

Implantação de Inovações na Organização (processo MR-MPS)

Instituto Nacional de Metrologia, Normalização e Qualidade

Industrial

Instituto Nacional de Proteção Intelectual

Instituições Organizadoras de Grupos de Empresas

Imposto sobre Produtos Industrializados

International Organization for Standardization

ISO/ International Electrotechnical Commission

Integração do Produto (processo MR-MPS)

Método de Avaliação para Melhoria de Processo de Software

Ministério da Ciência e Tecnologia

Medição (processo MR-MPS)

Massachussetts Institute of Technology

Modelo de Negócio Cooperado

Modelo de Negócio Específico

Modelo de Negócio para Melhoria de Processo de Software

Micro, Pequenas e Médias Empresas

Melhoria de Processo de Software

Melhoria de Processo do Software Brasileiro

Modelo de Referência para Melhoria de Processo de Software

Nova Economia Institucional

Organização para Cooperação e Desenvolvimento Econômico

Programa Brasileiro da Qualidade e Produtividade de Software Política Industrial, Tecnológica e de Comércio Exterior

Pequenas e Médias Empresas

Programa para o Desenvolvimento da Indústria Nacional de

Software e Serviços Correlatos 
RAIS

S\&SC

SECI

SEI

SEI

SEPIN

SOFTEX

SLP

STE

SW/CMM

TER

$\mathrm{TI}$

TIC

VAL

VER
Relação Anual de Informações Sociais

Software e Serviços Correlatos

Socialização, Externalização, Combinação e Internalização

Secretaria Especial de Informática

Software Engineering Institute

Superintendência de Estatística, Pesquisa e Informação

Sociedade para Promoção da Excelência do Software Brasileiro

Sistema Local Produtivo

Solução Técnica (processo MR-MPS)

Software Capability Maturity Model

Treinamento (processo MR-MPS)

Tecnologia de Informação

Tecnologias da Informação e da Comunicação

Validação (processo MR-MPS)

Verificação (processo MR-MPS) 


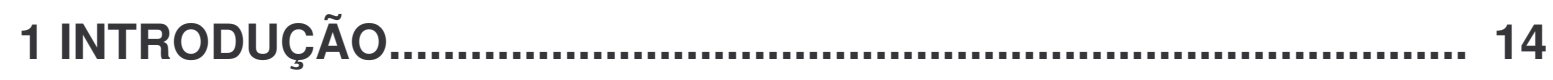

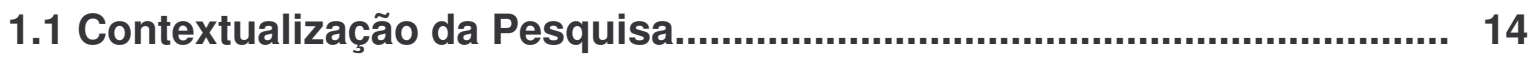

1.2 Definição do Problema e Justificativa...................................................... 16

1.3 Objetivos da Pesquisa.......................................................................... 22

1.4 Questões de Pesquisa....................................................................... 23

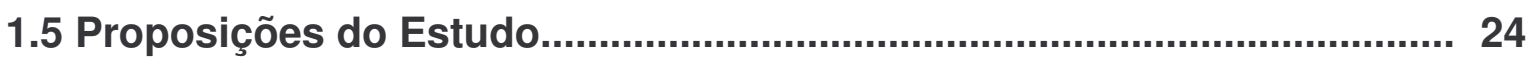

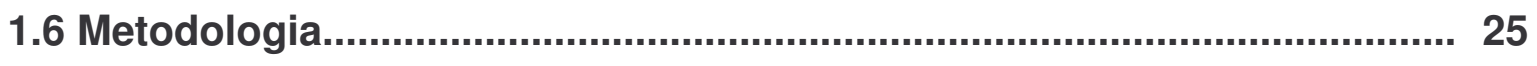

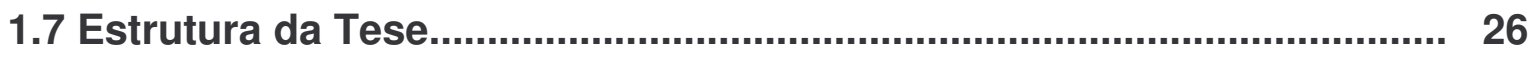

2 REFERENCIAL TEÓRICO....................................................... 28

2.1 A importância dos aspectos locais para o desenvolvimento econômico e competitividade das empresas............................................... 28

2.2 Uma revisão das bases teóricas dos aglomerados produtivos e redes de cooperação.............................................................................. 32

2.3 Custos de Transação e Governança.................................................... 38

2.4 A cooperação entre os agentes e o Capital Social.................................. 41

2.5 Políticas Públicas de promoção e desenvolvimento de aglomerados produtivos e redes de cooperação.................................................................. 46

2.6 Principais Tipologias de Aglomerados Produtivos e Redes de

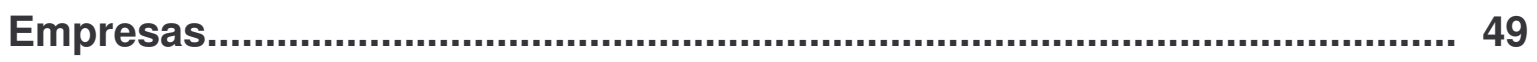

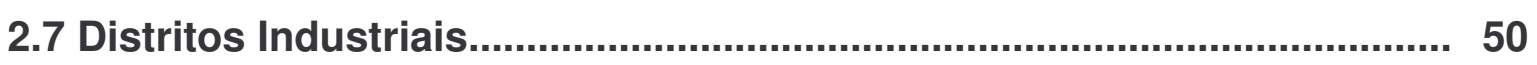

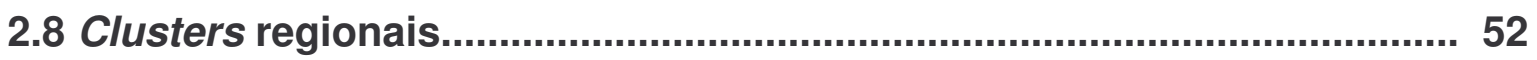

2.9 Millieu Inovateur - Ambiente inovador................................................. 56

2.10 Cadeias produtivas..................................................................... 57

2.11 Arranjos e Sistemas Produtivos Locais................................................ 58

2.12 Redes de cooperação entre empresas............................................... 62

2.13 Origem e Conceitos de Redes........................................................... 64

2.14 Tipologias de redes interorganizacionais............................................ 67

2.15 Redes Top-down e Flexíveis............................................................ 70 
2.16 Organizações e Empresas Virtuais..................................................... 71

2.17 Comunidades de Prática................................................................... 72

2.18 Orientação Conceitual das dimensões sobre redes.............................. 74

2.19 Redes Interorganizacionais e suas contribuições para as

Pequenas e Médias Empresas.................................................................. 76

2.20 A natureza do Conhecimento........................................................... 81

2.21 Dimensões do Conhecimento......................................................... 83

2.22 As dimensões dos processos de aprendizagem................................. 89

2.23 Considerações Finais do Capítulo........................................................ 91

\section{CONSIDERAÇÕES SOBRE A INDÚSTRIA DE SOFTWARE}

E SEU CONTEXTO......................................................................... 97

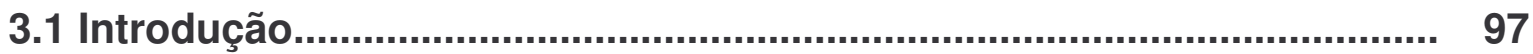

3.2 Características e configurações gerais da atividade e/ou

"indústria de software" ............................................................................ 100

3.3 Tipologias das atividades de software................................................. 104

3.4 Breve histórico da indústria de software............................................ 108

3.50 contexto internacional da indústria de software................................ 110

3.6 O desenvolvimento da atividade de software no Brasil........................ 115

3.6.1 Principais aspectos da Lei de Informática....................................... 118

3.7 O Software como opção estratégica na PITCE...................................... 120

3.8 Dados sobre a Indústria Brasileira de Software.................................... 123

3.90 Processo de Software...................................................................... 128

3.10 Melhoria de Processo de Software e Qualidade................................. 130

3.10.1 O modelo Software Capability Maturity Model (SW-CMM)............... 131

3.10.2 O Modelo Capability Maturity Model Integration (CMMI).................. 131

3.10.3 A Norma ISO/IEC 12207 - Processo de ciclo de vida de software... 136

3.10.4 A Norma ISO/IEC 15504 - Information Technology - process assessment................................................................................... 137

3.10.5 Melhoria de Processo do Software Brasileiro - MPS.BR................. 138

4 METODOLOGIA........................................................................ 149

4.1 A pesquisa científica........................................................................... 149

4.2 Definição da Abordagem Macro da Pesquisa........................................ 150 
4.3 Definição do Método de Procedimento da Pesquisa.

4.4 Procedimentos de coleta de dados...................................................... 156

4.5 Etapas da pesquisa de campo..................................................... 158

5 A DINÂMICA DA APRENDIZAGEM EM APL'S DE SOFTWARE 161

5.1 Origem e desenvolvimento do APL de Campinas................................. 161

5.1.1 Agentes de Coordenação Local e suas funções................................. 166

5.1.2 Interações e Processos de aprendizado no APL de Campinas.......... 172

5.2 Origem e Caracterização do APL de Belo Horizonte............................... 170

5.2.1 Agentes de Coordenação Local e suas funções................................ 178

5.2.2 Interações e Processos de aprendizado no APL de Belo Horizonte.. 183

5.3 Origem e desenvolvimento do APL de Blumenau................................ 188

5.3.1 Agentes de Coordenação Local e suas funções................................ 191

5.3.2 Interações e Processos de aprendizado no APL de Blumenau........... 195

5.4 Análise comparativa da dinâmica de interações e aprendizagem nos APLS de software......................................................................... 196

5.4.1 Análise dos principais aspectos de origem e desenvolvimento local

5.4.2 Governança e/ou coordenação local............................................ 200

5.4.3 Geraçao e difusão do conhecimento e aprendizado...............................201

6 CONCLUSÕES DA PESQUISA 210

REFERÊNCIAS BIBLIOGRÁFICAS.......................................... 215

APÊNDICE A - ROTEIRO DE ENTREVISTA ÀS INSTITUIÇÕES

DE APOIO ÀS EMPRESAS DO SETOR DE SOFTWARE............... 234

APÊNDICE B - LEVANTAMENTO SOBRE APRENDIZAGEM E 240 


\section{INTRODUÇÃO}

Este capítulo tem como objetivo apresentar a proposta desta tese de doutorado. Para isso, contém uma breve justificativa e contextualização da pesquisa que leva à estruturação do problema, aos objetivos e às proposições do estudo. Por fim, é feita uma breve descrição da metodologia da pesquisa e apresentada a estrutura da tese como um todo.

\subsection{Contextualização da Pesquisa}

Novos padrões de competitividade internacionais e nacionais vêm produzindo um notável acirramento da competição, desafiando as empresas não só a repensarem seus princípios e arranjos na organização do trabalho, mas também a buscarem novos tipos de estruturas organizacionais, estratégias e modelos de gestão para obterem vantagens competitivas, num cenário menos protegido econômica e politicamente.

A referência para a manifestação dessas várias tendências, se dá a partir da crise do antigo paradigma de produção, o modelo taylorista/fordista, com a desintegração das burocracias verticalizadas, o esgotamento da capacidade de inovar, paralelos ao crescimento da internacionalização das economias e os novos padrões internacionais de qualidade e produtividade.

As empresas passam a buscar um modelo mais enxuto e flexível e, portanto, cresce a necessidade das organizações se concentrarem nas suas principais competências e, paralelamente, estabelecerem parcerias para desenvolver produtos, serviços e processos aptos a responderem às mudanças contínuas do ambiente e a necessidade de produção de inovações. 
Destaca-se neste ambiente, a importância de um novo paradigma, que tem nos ativos intangíveis da economia, como conhecimento, aprendizado, capacitação, a alternativa para a obtenção de vantagens competitivas das empresas. As capacitações das empresas, em termos de produção e uso do conhecimento, tem cada vez mais um papel central na sua competitividade. Um aspecto importante da capacitação é o conhecimento em ferramentas e técnicas de melhoria, gestão da qualidade, entre outros, que tragam eficiência e eficácia às atividades das empresas.

No conjunto dessas transformações, as pequenas e médias empresas (PME's) são as que mais sofrem para se manterem ativas e competitivas, dada a sua dificuldade no que se refere ao acesso à informação, ao alcance de novos mercados e à criação de competências, características essenciais para a competitividade das empresas modernas.

Desse modo, ao competirem individualmente e não adotarem estratégias competitivas em mercados globalizados, onde as grandes empresas exercem vantagens sobre as menores (KRUGLIANSKAS, 1996; SANTOS \& VARVAKIS, 1999), a sobrevivência das PME's está fortemente ameaçada.

Vários estudos têm demonstrado que uma das formas mais eficientes das PME's se adequarem e lidarem com essas novas exigências e formas de competitividade é através da organização de empresas nos chamados arranjos produtivos locais ou redes locais, entre outros termos ${ }^{1}$, que serão explicitados ao longo desta tese, que caracterizam a concentração geográfica de empresas.

Dentre as vantagens oriundas deste tipo de configuração industrial, destacase o contexto propício para a inovação, em virtude da capacidade de geração e troca de conhecimentos que estes aglomerados possuem, por intermédio de processos de interação e cooperação entre os agentes locais (CASSIOLATO, 2005). Principalmente com fontes externas de conhecimentos, tais como, clientes e/ou usuários, fornecedores, concorrentes, universidades, centros de pesquisa, atividades de marketing, entre outros. O conhecimento, como resultado da

\footnotetext{
${ }^{1}$ sistemas produtivos locais, clusters de empresas, millieux inovateurs, distritos industriais, etc.
} 
capacidade de aprender e estabelecer relações constitui-se base principal para a criação de valor baseada em inovações, para melhorar/aperfeiçoar produtos e processos (GERTLER, 2001).

A importância e a necessidade crescente de troca de informações e aprendizado é ainda maior, ao se considerar as empresas que fazem uso intensivo de tecnologia e conhecimento, como é o caso da indústria de software, em virtude da instabilidade inerente a esse tipo de negócio (STUART, 1998). A qualidade e a melhoria dos processos envolvidos no contexto da atividade de desenvolvimento de software é uma atividade crítica, e hoje, um requisito fundamental (NOGUEIRA, 2006). O processo de desenvolvimento de software é realizado através de um esforço coletivo de criação. Seus resultados dependem diretamente das pessoas, das organizações e procedimentos utilizados em sua construção (FUGETTA, 2000).

A atividade de software apresenta-se como uma atividade de importância estratégica para o desenvolvimento da competitividade de organizações e países. No Brasil, ela é alvo de políticas públicas para o seu fortalecimento, e entre suas prioridades, capacitar as empresas em melhoria de processos. Portanto, o investimento nesta atividade como ativo de inovação é de profunda relevância.

Assim, diante do exposto, essa tese tem como preocupação principal oferecer contribuições aos estudos de redes de conhecimento em aglomerações produtivas, através da análise da dinâmica de aprendizado das PME's de software em processos interativos, a fim de que seja conhecida a forma como essas empresas buscam aumentar suas capacitações em melhoria de processos de software.

\subsection{Definição do Problema e Justificativa}

Na literatura sobre aglomerações produtivas há um consenso entre vários estudos (PORTER,1998; HUMPHREY e SCHMITZ, 1998; NADVI e SCHMITZ, 1999; entre outros) de que a promoção de ações conjuntas entre empresas e outras 
organizações potencializa o ganho de eficiência que a concentração geográfica de empresas de um mesmo setor pode ter. Esse ganho de eficiência é decorrente da combinação de economias externas (incidentais, não planejadas), tais como, a existência de mão de obra especializada e portadoras de habilidades específicas ao sistema local, presença e atração de um conjunto de fornecedores especializados de matéria-prima, componentes e serviços e disseminação dos conhecimentos, habilidades e informações relacionadas à atividade dos produtores locais (spillovers de conhecimento); com as economias de ações conjuntas deliberadas, tais como, compra de matéria-prima, promoção de cursos de capacitação para a formação profissional, criação de consórcios especializados, centros tecnológicos de uso coletivo, entre outras. A soma desses dois fatores é definida como eficiências coletivas (SCHMITZ, 1995).

As ações conjuntas nas concentrações de empresas dependem da existência de formas de governança ou coordenação do local que estimulem a manutenção de relações cooperativas entre os agentes, estimulando a competitividade do conjunto de produtores (SUZIGAN et. al, 2003). Entender quais atores têm o poder, a estrutura de comando ou a governança local capazes de afetar as ações e o desenvolvimento de um arranjo produtivo é de fundamental importância para compreender o fomento das atividades interativas e a difusão do conhecimento. A combinação de estruturas adequadas com um ambiente criativo e cooperativo é uma diretriz fundamental nas políticas de desenvolvimento local.

Entre as ações de fomento às atividades conjuntas, destacam-se aquelas coordenadas pelo setor público através dos governos locais criando ou apoiando centros de treinamento de recursos humanos, prestação de serviços tecnológicos, agências governamentais de desenvolvimento, entre outros no suporte às atividades de apoio e de prestação de serviços ao setor produtivo. E no caso da governança privada local, destaca-se o papel das associações de classe e de agências locais privadas que atuam como catalisadores do processo de desenvolvimento local (SUZIGAN et. al. 2002).

Vários autores caracterizam os arranjos produtivos como um locus privilegiado para as diferentes formas de interações e formações de redes entre os 
agentes locais. Sobretudo no que diz respeito à criação e o compartilhamento de conhecimento, os quais criam condições para a inovação, entendida, fundamentalmente, não só como resultado de um processo de aprendizado organizacional, mas também interorganizacional. (LUNDVALL, 1988 e 1992; DOSI, 1988; DOSI e MALERBA, 1996; EDQUIST, 1997; PAVITT, 1984).

A participação em redes organizacionais que privilegiam a interação e a atuação conjunta entre os agentes econômicos, coloca-se como estratégia importante para as empresas, sobretudo para as de pequeno e médio portes, para mobilizar a geração, aquisição e difusão de conhecimentos que levam à inovações, uma vez que o processo de inovação nas empresas demanda tanto o acesso a conhecimentos, como a capacidade de apreendê-los, acumulá-los e usá-los. A habilidade em criar e utilizar conhecimento para gerar inovação em produtos e processos constitui-se um grande desafio e praticamente uma das mais importantes fontes de sustentabilidade de vantagens competitivas para as empresas (PRAHALAD e HAMEL, 1990; NELSON, 1991; KOGUT e ZANDER, 1992; GRANT, 1996; NONAKA e TOYAMA, 2002).

O conceito de rede em geral é bastante abrangente e complexo, podendo designar um conjunto de pessoas ou organizações interligadas direta ou indiretamente (MARCON \& MOINET, 2000) ou definido como o método organizacional de atividades econômicas através de coordenação e/ou cooperação inter-firmas (PORTER, 1998). Na literatura corrente também são equivalentes as formas especiais de alianças estratégicas entre empresas/organizações através das quais, as firmas podem viabilizar o atendimento de uma série de necessidades, que seriam difíceis de satisfazer através da atuação isolada (AMATO NETO, 2000). As empresas podem cooperar no desenvolvimento de projetos comuns através de ações especializadas de complementaridade para a resolução de problemas e/ou necessidades comuns que vão além do alcance isolado das empresas (CEGLIE e DINI, 1999).

As redes, quando bem equilibradas em termos de tamanho, coesão, densidade, diversidade e reputação, permitem acesso a informação, conhecimento e 
legitimidade, recursos essenciais ao sucesso dos empreendimentos sociais (HULSINK e ELFRING, 2003).

O conhecimento organizacional toma forma através da aprendizagem interna ou de capacitações formadas no próprio ambiente de trabalho (learning by doing e learning by using - aprender fazendo) que geram um aumento na eficiência produtiva e um fluxo contínuo de modificações e inovações incrementais em processos e produtos; e através da aprendizagem externa por meio de interações com fontes externas (learning by interaction) (fornecedores/usuários, sistemas nacionais de inovação, ambiente e outras firmas) (LUNDVALL,1992; NELSON e WINTER, 1982; DOSI, 1988 e FREEMAN, 1987).

A principal vantagem dessas interações é a construção de um conhecimento tácito que só é possível pela proximidade espacial e cuja transferência depende do contexto social, e as instituições estabelecidas nessa localidade. Para aproveitar os conhecimentos de fontes externas, é fundamental a interação permanente e regular com outras organizações, mas também indispensável o desenvolvimento de habilidades internas para incorporar os conhecimentos e torná-los específicos à firma, desenvolvendo a capacidade cognitiva da organização.

O conhecimento interorganizacional é uma das dimensões mais amplas da criação do conhecimento, iniciando-se no nível individual e, através da interação entre conhecimento tácito (subjetivo) e explícito (objetivo), entre indivíduos, grupos e organizações, transforma-se em um nível de conhecimento mais abrangente e expressivo (NONAKA \& TAKEUCHI, 1997). Isto demonstra que mesmo na aprendizagem externa, o conhecimento interno está compreendido. Entretanto, conforme Lundvall (1996), a capacidade de inovar está fortemente condicionada ao conhecimento gerado fora da empresa, o qual é captado através de processos de aprendizagem que ocorrem nas interações entre firmas e instituições/organizações locais. Portanto, este trabalho parte do pressuposto que embora as interações com fontes internas sejam importantes, as fontes externas são as principais responsáveis pela geração de conhecimento nas empresas integrantes de aglomerações produtivas. 
A análise da transferência do conhecimento deve contemplar três dimensões, que podem determinar a facilidade ou não com que o conhecimento pode ser transferido: 1) dimensão simples $x$ complexo - refere-se ao volume de informações que deve ser transmitido para que a transferência do conhecimento ocorra; 2) dimensão independente $x$ sistêmico - diz respeito ao fato de determinada informação ou conhecimento poder ser transferido sozinho ou necessitar ser transferido como parte de um "pacote" que agrega diferentes conhecimentos; 3) dimensão tácito x explícito - refere-se aos vetores ou veículos através dos quais o conhecimento pode ser transmitido. (NAKANO, 2005).

Segundo Gertler (2001), a habilidade dos trabalhadores e das firmas para gerar e compartilhar conhecimento tácito depende da proximidade espacial e das afinidades culturais. Mais ainda, depende substancialmente do compartilhamento de normas, convenções, valores, expectativas e rotinas que nascem da experiência comum moldada pelas instituições (hábitos comuns, rotinas, práticas, regras e leis que regulam as interações e relações entre indivíduos e grupos) (NELSON e WINTER,1982; NADVI, 1995; SCHMITZ, 1997).

É importante considerar que quanto maior a rede de relacionamentos e contatos, mais possibilidades de obter informações e conhecimentos sobre seus parceiros a organização terá, e portanto, poderá ter mais probabilidade de estabelecer relações mais proveitosas (NAKANO, 2005).

Essa rede de relações interpessoais e/ ou intergrupais de cooperação também são chamados na literatura de capital social (PUTNAM, 2002). Este determina as relações de interdependência e cooperação entre os agentes que devem ser consolidadas através da construção de uma visão de parceria em substituição a uma visão de competição. A principal contribuição do capital social no fortalecimento das aglomerações produtivas revela-se na criação de um sistema de valores comuns que contribui para a união da região em torno de um objetivo comum. Nesta perspectiva, o capital social pode proporcionar a redução de potenciais conflitos e contribuir para os processos de aprendizado, de criação e compartilhamento de conhecimentos e habilidades, uma vez que as relações puramente de mercado têm-se mostrado incapazes de estimular as interações entre 
os agentes (ALBAGLI e MACIEL, 2002; SILVA, 2006; MARTELETO e SILVA, 2004; BOURDIEU, 1998; DEGENNE, 2004).

Para a indústria de software, especificamente, os processos de aprendizado e a conversão do conhecimento necessitam ser bastante efetivos, dada a característica proeminente da velocidade com que as inovações são introduzidas e transformadas em novos produtos e processos, assim como também se tornam obsoletas rapidamente, dado ao caráter de intenso dinamismo tecnológico e organizacional desta atividade, o que a torna uma indústria altamente inovativa. Os softwares possuem ciclo de vidas muito curtos, ocorrendo a necessidade de surgimento incessante de novos produtos, segmentos de mercado e uma grande população de firmas novas e inovadoras. A alta oportunidade e variedade de opções tecnológicas na industria de software reduzem as possibilidades de obtenção de rendas de longo prazo e tornam as condições de apropriabilidade dependentes da contínua introdução de inovações (BRESCHI e MALERBA, 1997).

O conhecimento é o insumo quase exclusivo de todo o processo de desenvolvimento de software. Isto faz com que os conhecimentos e capacitações acumulados pelas pessoas se tornem ativos estratégicos (PONDÉ, 1993). A cumulatividade de conhecimentos possibilita a criação de posições competitivas privilegiadas para a indústria de software, ao mesmo tempo em que representa uma importante barreira dinâmica ao crescimento de empresas entrantes (BRESCHI e MALERBA, 1997).

É comprovado pela literatura a tendência de formação de aglomerados de empresas de software em determinadas regiões, como o caso do Vale do Silício nos EUA, Bangalore na Índia e Dublin na Irlanda. Nos países periféricos, como é o caso do Brasil, as aglomerações locais podem representar um importante foco de desenvolvimento das PME's, no sentido de ampliar as suas capacitações e aumentar suas chances de sobrevivência.

Considerando a importância do software como atividade econômica no Brasil e no mundo, o governo federal tem como meta a promoção desta indústria, e entre suas prioridades o fomento à melhoria da qualidade e a certificação de produtos e 
processos associados ao software a fim de aumentar a competitividade e fortalecer o processo de inovação das empresas.

Desta forma, essas argumentações orientam a condução da pesquisa e estimulam o interesse desta tese em responder a seguinte questão central:

Como ocorre a dinâmica de aprendizado das PME's de software em processos interativos?

\subsection{Objetivos da Pesquisa}

Propõe-se como objetivo principal deste estudo ampliar o conhecimento sobre a dinâmica de aprendizagem das PME's intensivas em conhecimento em ambientes interativos. Para isso pretende-se analisar através da pesquisa os mecanismos ou formas de aprendizado e difusão do conhecimento através dos quais as PME's constroem suas capacitações.

Os objetivos, de caráter secundário, associados ao processo de pesquisa são:

1) Identificar e avaliar os mecanismos de aprendizado disponíveis em escala local que possibilitem o incremento ou a redução de assimetrias de conhecimento;

2) Identificar as principais fontes externas de conhecimento utilizadas pelas empresas e como as empresas as escolhem;

3) Descrever e analisar o processo de transferência de conhecimento em ambientes de interação identificados;

4) Analisar se a estrutura de governança ou coordenação local é funcional e/ou estimula os processos de aprendizado relacionados à qualidade e melhoria de processos de software das PME's;

5) Analisar a conformação institucional do ambiente local. 


\subsection{Questões de Pesquisa}

Para atender aos objetivos propostos é necessário que algumas questões relevantes sejam respondidas.

1) Mecanismos e Processos de Aprendizado: Como ocorre a circulação e o intercâmbio de informações, disseminação de conhecimentos e bestpratices no interior dos arranjos? Existem assimetrias de informação entre os agentes? Há predominância de mecanismo informais ou formais? Como se caracteriza a sua ocorrência? Como é o perfil da mão-de-obra, os requisitos de qualificação, os esforços em desenvolvimento de recursos humanos? Como as informações são agregadas às experiências e habilidades existentes na firma para promover atividades de inovação, entre outras.

2) Fontes externas de conhecimento:Como se relacionam com essas fontes?

3) Como é o processo de transferência de conhecimento? Como é o uso dos canais e códigos de comunicação? Como é a infra-estrutura facilitadora do intercâmbio de informações? Como ocorre a troca de conhecimentos? Qual a natureza das informações Quais os vetores de transmissão do conhecimento?

4) Como está organizada a estrutura local do arranjo (governança) no que se refere à promover, fomentar ou potencializar as interações e os processos de aprendizado entre os agentes? Quem são os principais agentes de conhecimento? Como os sistemas de informação estão disponibilizados e os instrumentos mobilizados para viabilizar a circulação de conhecimentos entre os agentes integrados ao arranjo produtivo?

5) Como é a conformação institucional ou do capital social local ? Como os elementos sociais e culturais do arranjo influenciam nos processos de 
aprendizado no sentido de propiciar e/ou potencializar as interações e cooperações entre os agentes?

\subsection{Proposições do Estudo}

As proposições ou pressupostos direcionam o alvo do pesquisador a ser examinado dentro do escopo do estudo (YIN, 2001).

Nesta pesquisa serão consideradas as seguintes proposições:

\section{Proposicão Básica:}

Os processos de aprendizagem por interação são determinantes para as PME's de software na construção de conhecimento e geração de capacitações inovativas.

\section{Proposicões Secundárias:}

As sinergias coletivas geradas pelas aglomerações de empresas em determinado espaço territorial fortalece as chances de sobrevivência e crescimento das PME's.

As fontes externas de conhecimento são as principais responsáveis pela geração de conhecimento nas empresas integrantes de aglomerações produtivas.

A governança local e a conformação institucional podem facilitar ou inibir a reunião de complementaridades, as trocas de informações e os processos de aprendizado das firmas. 


\subsection{Metodologia}

Este tópico se deterá em indicar uma síntese da metodologia da pesquisa, ou seja, a forma como o objeto de estudo foi abordado. O detalhamento de todo o percurso metodológico será apresentado no quarto capítulo desta tese.

Em linhas gerais, o estudo de campo foi realizado em três arranjos produtivos de software brasileiros: i) APL de Software de Campinas - SP; ii) APL de Software de Blumenau - SC; iii) APL de Software de Belo Horizonte - MG.

A escolha levou em conta o fato desses pólos pertencerem às regiões de maior nível de ocupação de empresas brasileiras desenvolvedoras de software (RAIS 2003). Esses arranjos possuem características peculiares que revelam aspectos interessantes sobre a construção do conhecimento através dos processos de aprendizado interativo das empresas.

Para a apresentação da síntese da metodologia, este estudo adotou o critério de classificação de pesquisa de Gonsalves (2001) por ser prático e suscinto. Entretanto, no quarto capítulo (Metodologia), outras abordagens também serão utilizadas como referencial, e as informações receberão um tratamento mais detalhado e aprofundado. De acordo com a autora, as pesquisas podem ser classificadas, basicamente, segundo seus objetivos, seus procedimentos de coleta, suas fontes de informação e a natureza dos seus dados (ver tabela 1.1).

Com base nos critérios apresentados, esta tese possui a seguinte configuração metodológica:

i) Segundo o objetivo: é uma pesquisa exploratória, cuja finalidade é compreender um fenômeno contemporâneo, pouco explorado em seu contexto real.

ii) Sequndo o método de procedimento de coleta utilizado: é um estudo de caso, ou de multiplos casos comparativos (Yin, 2001), por analisar mais de uma unidade específica de estudo e realizar um exame de profundidade sobre o problema investigado. 
Tabela 1.1 - Critérios de classificação de pesquisa

\begin{tabular}{|l|l|l|l|}
\hline $\begin{array}{c}\text { Tipos de pesquisa } \\
\text { segundo os } \\
\text { objetivos }\end{array}$ & $\begin{array}{c}\text { Tipos de pesquisa } \\
\text { segundo os } \\
\text { métodos de } \\
\text { procedimentos de } \\
\text { coleta }\end{array}$ & $\begin{array}{c}\text { Tipos de pesquisa } \\
\text { segundo as fontes } \\
\text { de informação }\end{array}$ & $\begin{array}{c}\text { Tipos de pesquisa } \\
\text { segundo a natureza } \\
\text { dos dados }\end{array}$ \\
\hline - Exploratória & - Experimento & - Campo & - Quantitativa \\
- Descritiva & $\begin{array}{l}\text { - Levantamento } \\
\text { - Experimental }\end{array}$ & $\begin{array}{l}\text { - Laboratório } \\
\text { - Expludo de Caso }\end{array}$ & - Bibliográfica \\
- Bibliográfica & - Documental & \\
\hline
\end{tabular}

Fonte: Gonsalves (2001:64)

iii) Segundo as fontes de informacão: é uma pesquisa de campo porque envolve a presença do pesquisador onde o fenômeno ocorreu. É também uma pesquisa bibliográfica e documental, pois se utiliza, fundamentalmente, das contribuições de diversos autores sobre um determinado assunto, e de materiais que não receberam ainda um tratamento analítico.

iv) Segundo a natureza dos dados: é uma pesquisa qualitativa, pois envolveu uma busca profunda da compreensão e interpretação do fenômeno estudado.

\subsection{Estrutura da Tese}

O trabalho foi desenvolvido e estruturado da seguinte forma:

O primeiro capítulo - Introdução - apresenta uma caracterização geral do tema da pesquisa e do objeto de estudo, definindo os objetivos e pressupostos da pesquisa e destacando a importância do tema direcionado aos processos aprendizado das PME's. 
O segundo capítulo - Referencial Teórico - expõe a base teórica ou os conteúdos que deram sustentação ao trabalho e que serviram como referencial de análise do estudo sobre as redes de conhecimento e aprendizado das PME's em aglomerados produtivos locais. O capítulo apresenta as principais bases teóricas das aglomerações produtivas, com destaque para os aspectos locais que trazem vantagens competitivas às empresas. Descreve as principais formas de redes de empresas que propiciam a geração de conhecimento. Por fim, expõe as dimensões do conhecimento e dos processos de aprendizado.

O terceiro capítulo - Considerações sobre a indústria de software e seu contexto - apresenta, em um primeiro momento, aspectos gerais da indústria no contexto da Tecnologia de Informação (TI) com destaque para a dinâmica competitiva do setor e a natureza dos sistemas de software. Num segundo momento são apresentados os principais conceitos e modelos de gestão de processos e de melhoria da qualidade para o desenvolvimento e manutenção de software.

O quarto capítulo - Metodologia - apresenta e descreve a metodologia utilizada na pesquisa, bem como as razões que justificam a sua escolha, definindo os instrumentos e procedimentos utilizados no trabalho de campo.

O quinto capítulo - Processos de Aprendizado e Conhecimento em APL's apresenta as descrições e análises dos casos e um estudo comparativo.

O sexto capítulo - Conclusões da Pesquisa - apresenta os principais resultados obtidos através da pesquisa, sua importância, limitações e desdobramentos futuros. 


\section{REFERENCIAL TEÓRICO}

\section{“AGLOMERAÇÃO DE EMPRESAS, REDES DE COOPERAÇÃO, GERAÇÃO E DIFUSÃO DO CONHECIMENTO E APRENDIZAGEM"}

Este capítulo tem como objetivo apresentar a base teórica ou os conteúdos que deram sustentação à este trabalho e que serviram como referencial de análise do estudo sobre as redes de conhecimento das PME's em aglomerados produtivos locais. A perspectiva principal recai sobre as vantagens competitivas dinâmicas derivadas de externalidades locais, principalmente das interações e práticas de ações conjuntas que propiciam o compartilhamento e a geração de conhecimento através de processos de aprendizado entre os agentes.

2.1 A importância dos aspectos locais para o desenvolvimento econômico e competitividade das empresas

A literatura sobre a importância dos aspectos locais para o desenvolvimento econômico e competitividade das empresas é de crescente relevância nos estudos da economia industrial e regional, bem como de interesse de várias áreas do conhecimento (SUZIGAN et. al, 2003) como, geografia, sociologia e, particularmente a engenharia de produção, onde também tem crescido significativamente em importância nos últimos anos.

Esses estudos dão atenção especial às aglomerações setoriais de empresas, que através da cooperação, criam diferenciais competitivos significativos para as firmas aí localizadas. Tradicionalmente, na economia industrial, a questão da localização era vista principalmente pelos seus aspectos de custo de transporte e de 
acesso a insumos e serviços e, por conseqüência, os rumos da política industrial. Tampouco questões tipicamente locais como a relação do espaço com o conhecimento técnico/comercial, confiança, cooperação, aprendizado, instituições e outros elementos eram estudados e analisados como na atualidade (GONÇALVES E GÁVIO, 2002; SANTOS et al, 2004).

Em Krugman (1991), um dos autores da abordagem da geografia econômica, é possível encontrar algumas características positivas com relação à concentração geográfica: i) mão de obra especializada: a concentração de um número de firmas num mesmo lugar permite um mercado agrupado de trabalhadores com habilidades especializadas; ii) fornecedores e prestadores de serviços especializados: um aglomerado de empresas possibilita a provisão de entradas específicas para uma indústria em uma grande variedade e a um baixo custo; iii) transbordamentos (spillovers) tecnológicos e de conhecimento: externalidade ${ }^{1}$ resultante da proximidade local das firmas que possibilita a informação fluir mais fácil do que ocorreria se as empresas estivessem separadas por grandes distâncias.

Schmitiz (1999) destaca que as aglomerações atraem compradores e com isso facilita o acesso a mercados distantes. Os produtores podem simplesmente usar os canais de mercado resultantes das economias incidentais da aglomeração ou organizar ações conjuntas (feiras de negócios, certificação de produtos, entre outras ações) para atingirem mercados distantes. A soma de economias externas e ações conjuntas resultam em eficiências coletivas, que representa a vantagem competitiva derivada de economias externas locais e ações conjuntas.

Na nova literatura sobre desenvolvimento regional e local é dado destaque ao papel do conhecimento, onde as regiões passam a ser consideradas elementos fundamentais, uma vez que atuam como coletoras e repositoras de idéias, portanto, criadoras de conhecimento, propiciando o processo de aprendizado e constituindose como fontes de inovação e crescimento econômico.

\footnotetext{
1 benefícios incidentais gerados por fatores existentes em uma região com concentração de empresas do mesmo setor, tais como, mão de obra especializada, fornecedores e prestadores de serviços especializados, transbordamentos tecnológicos de conhecimento.
} 
Porter (1988) afirma que em uma economia global, a vantagem competitiva duradoura consiste cada vez mais em aspectos locais - conhecimento, relacionamento, motivação - que concorrentes distantes não podem combinar.

Para Humphrey (2003), a "competência" de inovação e melhoria é inerente aos aglomerados. Em especial, o fato de que essa "competência" está muitas vezes baseada em conhecimento tácito ${ }^{2}$, em confiança e estruturas institucionais difíceis de serem replicadas - o que valoriza ainda mais o conhecimento local. A soma de processos de produção e sistemas de conhecimentos que suportem a inovação são essenciais para a contínua melhoria e competitividade das empresas.

Em síntese, os ganhos advindos da concentração espacial das empresas que impulsionam o desenvolvimento podem vir de vantagens competitivas estáticas, relacionadas à localização (uso de infra-estrutura, acesso a serviços de empresas e instituições locais e as economias de proximidade) e de vantagens competitivas dinâmicas (desenvolvimento de projetos conjuntos de inovação de produtos e processos e a implantação de mecanismos de comercialização que visam alcançar mercados além do mercado local. As primeiras estão associadas à obtenção de eficiência coletiva passiva, enquanto as segundas à ganhos de eficiência coletiva ativa (VISSER apud LA ROVERE e CARVALHO, 2004).

Outro aspecto destacado pela literatura e que assume grande importância nos estudos de aglomerações locais e redes de cooperação refere-se à formação de valores comuns e ativos intangíveis fundamentais para a difusão e consolidação dos processos de aprendizagem interativa, fomentados pela troca de conhecimentos tácitos.

Dentre outras razões, a dimensão regional é essencial por causa da presença de: i) capacidade para desenvolvimento de capital humano e interação entre agentes; ii) redes formais e de contatos informais por meio de encontros planejados ou não, trocas de informação e relações entre fornecedores e consumidores; iii) 
sinergia associada ao compartilhamento de valores culturais, psicológicos e políticos quando um mesmo espaço econômico é ocupado; iv) apoio estratégico da administração local nas áreas de educação, inovação e suporte (ASHEIM, COOKE; GÁVIO, 2002).

Estudos sobre experiências bem sucedidas como as da Terceira Itália (áreas de clusters na Emília-Romanha - Itália) e do Vale do Silício tornaram-se referências importantes dos aspectos locais e das vantagens da concentração de empresas em determinado espaço para o desenvolvimento sócio-econômico regional. Nos últimos 30 anos essas regiões cresceram a taxas muito elevadas, estando entre as rendas per capita mais elevadas do primeiro mundo, configurando-se também como fontes geradoras de enormes quantidades de empregos bem remunerados. As razões destas características são justificadas pela literatura econômica na questão local (SANTOS et al., 2004).

Dentre outros fatores importantes, os estudos realizados por autores da escola neo-schumpeteriana (DOSI, 1988; FREEMAN, 1995; LUNDVALL, 2001; LIPIETZ e LEBORGNE, 1988) demostram a importância do conhecimento e da inovação como elementos cruciais para o sucesso competitivo de firmas, nações e regiões. Indicam também que as mudanças tecnológicas foram responsáveis em levar as várias atividades e setores produtivos a se readaptarem e a se reestruturarem. Outros autores, tais como, Storper (1994), Gereffi (1994), Galvão e Cocco (1999) e Putnam (2002) destacaram o papel do ambiente e dos vínculos locais, particularmente pelas diversas instituições e organizações no desenvolvimento da cooperação entre firmas e formação de redes. A importância dos processos de aprendizado a partir de conhecimentos peculiares às regiões é ressaltada como responsável por grande dinamismo econômico e tecnológico.

\footnotetext{
${ }^{2}$ conhecimento que é difícil de articular, de ser tocado, codificado, pois é pessoal e dependente do contexto no qual está inserido. Está enraizado à experiência de cada indivíduo e às habilidades desenvolvidas através da experiência prática.
} 


\subsection{Uma revisão das bases teóricas dos aglomerados produtivos e redes de cooperação}

Este tópico apresentará as principais bases teóricas relativas ao tema das aglomerações produtivas que ressaltam importantes contribuições para o entendimento das redes de cooperação interorganizacional.

Muitos dos conceitos encontrados nas diferentes linhas de pesquisa que buscam compreender e analisar os aglomerados produtivos desenvolveram-se a partir do estudo pioneiro sobre organização industrial de Marshall (1920). Seus estudos ficaram conhecidos pelo destaque dado às externalidades, às ações de cooperação e ao conhecimento no desempenho das firmas.

Ele foi o primeiro autor a descrever o fenômeno dos Distritos Industriais para retratar as aglomerações industriais de pequenas e médias empresas na área têxtil na Inglaterra, no século XIX, utilizando o termo para descrever a aglomeração territorial de empresas do mesmo ramo ou ramo similar, onde a mão-de-obra especializada, o insumo e a prestação de serviços estavam facilmente disponíveis e as inovações rapidamente conhecidas (SCHMITZ, 1997).

$\mathrm{Na}$ análise de Marshall (1920), as economias externas são apropriadas pelas firmas e geradas pela aglomeração de produtores, peculiarmente as que se referem à especialização dos agentes. Tal especialização, produzida por fornecedores e empresas correlatas e de apoio (termo atribuído por PORTER, 1993) produz mãode-obra qualificada, fornecedores e transbordamentos (spillovers) de conhecimento e tecnologia. Essa proximidade proporciona às firmas economias de custos de transação ${ }^{3}$ (conceito que será detalhado no tópico 2.3) decorrentes de economias de estoque, diminuição de preços de produtos e serviços, corroborando para maior interação entre elas.

\footnotetext{
${ }^{3}$ custos resultantes da obtenção das informações necessárias à realização de negócios, negociação de acordos e contratos de salvaguarda, entre outros (Willianson, 1985).
} 
Outro componente das economias externas são os transbordamentos de conhecimento e tecnologia, resultantes dos processos internos das firmas, os quais ultrapassam suas fronteiras e desenvolvem capacitações e habilidades no local. Tais trasbordamentos podem ocorrer em virtude da mobilidade de mão-de-obra que ocorre no local, bem como através de spin-offs. (estabelecimento de empresas concorrentes diretas ou fixadas para atender um nicho de mercado ou ainda para serem fornecedoras).

Apesar do reconhecimento da importância dos transbordamentos tecnológicos, para Marshall (1920) o conhecimento técnico é transferido de forma não intencional, não reconhecendo em sua análise que a proximidade geográfica leva a um aprendizado de caráter local.

Posteriormente em outros aportes teóricos, outros elementos importantes foram adicionados à discussão dos aglomerados produtivos.

As abordagens teóricas posteriores a Marshall, podem ser divididas em cinco linhas de trabalhos principais (FERREIRA JR. e SANTOS, 2006):

1) A Nova Geografia Econômica - representada pelos modelos da chamada nova teoria do crescimento e comércio internacional. Os trabalhos de destaque desta abordagem pertencem a Krugman (1991, 1995, 1999) que analisou os fatores que estimulam e desestimulam as aglomerações produtivas, defendendo que estas são resultantes da ação cumulativa gerada pela presença de economias externas locais, que são incidentais, e a estrutura espacial da economia determinada por movimentações do mercado que opera forças centrífugas e centrípetas.

Para este autor, a existência de condições favoráveis (retornos crescentes de escala) é capaz de intensificar e reforçar a concentração de empresas em que forças centrípetas apresentam-se em grande intensidade. Isto tende a levar além de maior concentração local de empresas ao aumento da competitividade do sistema, já que as condições que geram os retornos crescentes também tendem a serem intensificadas (GARCIA, 2001). 
Nesta abordagem não há espaço para as ações coletivas e a adoção de políticas públicas, uma vez que as economias externas são vistas como sendo de caráter exclusivamente incidentais. O foco dos estudos deste autor incide em mecanismos de mercado, como preços, estrutura de mercado e desempenho (MC DONALD \& BELUSSI, 2002), não reconhecendo ou minimizando em seus estudos a importância das instituições locais, formais e informais, os eventos históricos e as externalidades como transbordamentos.

2) Economia das Empresas - esta abordagem enfatiza a importância de economias externas geograficamente específicas (concentrações de habilidades e conhecimentos altamente especializados, instituições rivais, atividades correlatas e consumidores sofisticados) como fonte de vantagens competitivas.

Os trabalhos de Porter (1993, 1998, 1999) representam uma importante referência dessa abordagem que aponta para as aglomerações como meio de desenvolver a competitividade das empresas, dando destaque às forças de mercado como vitais para estimular o desempenho das firmas nos aglomerados e o papel das políticas públicas para corrigirem imperfeições de mercado e melhorarem a infraestrutura e estrutura de apoio (indústrias complementares e de apoio e instituições públicas e privadas) para que as empresas tenham acesso a produtos e serviços eficientes e diferenciados, que fomentem a produtividade e direcionem as firmas à inovação. A proximidade, não apenas de fornecedores, mas também de empresas rivais e clientes, são fatores de incentivo ao desenvolvimento empresarial dinâmico.

Outra importante influência integrante desta abordagem vem da linha da Nova Economia Institucional (NEI), com autores que tratam do conceito de custos de transação, como North (1990) e Willianson (1985), e que provêm um rico panorama sobre a racionalidade econômica baseada na racionalidade limitada num mundo repleto de incertezas e de comportamentos oportunistas. Uma limitação da teoria dos custos de transação apresentada nesta vertente de compreensão dos aglomerados é de que esta assume as aglomerações produtivas como sendo "mercados perfeitos", onde não ocorre nenhuma falha de mercado e a coordenação ex-post é perfeitamente atingida através dos mercados (ANTONELLI apud SILVA, 2006). Um ponto a ser destacado é a importância do papel da cooperação, da 
confiança e do sistema institucional presentes nos aglomerados produtivos que influenciam as inovações.

3) Economia da Inovação - esta influência é representada por diferentes abordagens e contribuições no campo da inovação. Tem como foco o desenvolvimento tecnológico e a formação de sistemas de inovação decorrentes da interação das empresas e outros agentes. Procura-se entender o papel da mudança tecnológica no desempenho competitivo e econômico das firmas, e o impacto da inovação no desenvolvimento regional e nacional. Vai além das observações de Marshall com respeito aos spillovers atribuindo à proximidade local a capacidade de facilitar os fluxos de informações e a disseminação do conhecimento.

Destacam-se nessa abordagem as contribuições de Nelson e Winter (1982), sobre economia evolucionária e da inovação, Freeman (1987) e Lundvall (1995) com o conceito de Sistemas Nacionais de Inovação e outros estudos relacionados à sistemas de inovação em nível local e regional, e proximidade e inovação.

4) Economia Regional (desenvolvimento dos distritos industriais) representada por abordagens e estudos dos distritos industriais da Europa, sobretudo Itália, que destacam a importância de arranjos sócio-econômicos específicos e o papel das pequenas e médias empresas nesse contexto. Um dos enfoques principais é a inter-relação entre geografia econômica e desempenho industrial. Dentre outros autores, destacam-se nesta linha de pesquisa as contribuições de Becattini (1979,1989, 1990, 1998), onde a Escola Italiana tem suas origens, Storper (1996, 1997), Scott (1998), Brusco (1990), Markusen (1995), Rabelotti (1995) e Viesti (2000).

Uma das principais argumentações nesta abordagem, refere-se a identificação de uma tendência endêmica ao capitalismo em direção à formação de aglomerações produtivas localizadas que são constituídas como economias regionais intensivas em transações, mas ao mesmo tempo, enlaçadas por estruturas de interdependência dispersas. A performance industrial e os padrões de localização estão intrinsecamente associados à geografia, sendo que há determinantes históricos complexos que influenciam a localização industrial. Para a construção de 
vantagens competitivas localizadas é necessário uma forte coordenação extramercado e a existência de políticas públicas.

$\mathrm{Na}$ análise da estrutura dos distritos industriais, destaca-se Beccatini (1998) descrevendo a importância de três elementos: i) a comunidade local: como um sistema homogêneo de valores e regras que são partilhados entre as pessoas e formam a base preliminar de desenvolvimento do aglomerado, ao mesmo tempo em que determinam algumas das condições de sua evolução e servem de base para a tomada de decisões de ordem econômica; ii) a população de firmas: que refere-se a decomposição do processo produtivo pela especialização das empresas em fases do processo, sendo importante para atender as flutuações de demanda, tanto para baixo quanto para cima, fazendo com que o ambiente local seja composto pelo desenvolvimento contínuo de transações; iii) os recursos humanos: importantes ao sistema em virtude da mobilidade da mão-de-obra, fazendo com que esse movimento favoreça o aprendizado coletivo baseado na interação entre pessoas e empresas.

Ainda uma outra característica marcante da literatura italiana está na importância dada ao equilíbrio entre cooperação e competição, os quais dão suporte à divisão do trabalho e seus efeitos na integração social. Através da cooperação é possível que sejam economizados custos de transação, permitindo a flexibilização e, consequentemente, a inovação.

Por fim, as características comuns presentes nas abordagens que definem os distritos industriais na literatura, são: a forte sinergia local, impulsionadora do crescimento econômico, a forte capacidade inovadora das regiões, a permanente busca de novas alternativas técnicas e de gestão, uma forte sustentação inicial por meio público e forte apoio no desenvolvimento endógeno dos recursos humanos.

5) Pequenas Empresas e Distritos Industriais - nesta abordagem desponta um importante conceito, o de "eficiência coletiva", no qual Schmitz (1997) e Nadvi \& Schmitz (1999) destacam que além das economias externas locais incidentais, existe uma força consciente e deliberada em ação, derivada de ações conjuntas/cooperativas entre agentes privados e apoio do setor público que 
combinados constroem vantagem competitiva. Os efeitos incidentais são passivos, gerados pela concentração geográfica, ou seja, a simples proximidade física entre empresas já traz vantagens (formação de mão-de-obra capacitada, surgimento de spillovers e atração de fornecedores especializados e o surgimento de agentes que vendam para mercados distantes). Já os efeitos deliberados permitem que os agentes possam resolver, de modo coletivo, problemas comuns, o que contribui para o processo de geração de vantagens competitivas e representam um importante elemento para o fomento do aprendizado local, uma vez que a aglomeração dos produtores facilita e estimula interações freqüentes entre os agentes.

Um aspecto a ser destacado é de que as ações conjuntas não requerem um relacionamento formal ou uma interação próxima das firmas, elas podem até acontecer, mas não se trata de um pré-requisito. As firmas podem ter acesso aos fatores que explicam as bases dos spillovers de conhecimento, tais como a mobilidade da mão-de-obra, a observação de concorrentes através de processos de imitação, circulação de "fofocas" e rumores.

Como pode-se observar, muitos autores e teorias contribuíram para a melhor compreensão do fenômeno das aglomerações produtivas, desde o estudo clássico de Marshall até contribuições mais recentes. Apesar de apresentarem pontos divergentes, as diferentes vertentes teóricas são convergentes em alguns aspectos considerados essenciais para a construção de vantagens competitivas: i) em quase todas, os conceitos e estratégias partem (ainda que minimamente) do mesmo referencial, as economias externas marshallianas; ii) resgatam a importância da diversidade de formatos institucionais refletidos na dimensão local do aprendizado tecnológico; iii) atribuem significativa e crescente importância às aglomerações produtivas locais como elemento central na competitividade econômica e no dinamismo tecnológico das firmas, dentre outros (FERREIRA JR. e SANTOS, 2006).

Apesar das diferenças entre os aportes teóricos que procuram captar a diversidade empírica, pode-se perceber que as preocupações parecem ser semelhantes nos diferentes fenômenos estudados. 


\subsection{Custos de Transação e Governança}

Este tópico tem como objetivo detalhar o conceito de custos de transação e das formas de coordenação utilizadas nas redes.

A Economia dos Custos de Transação (ECT) surge como uma nova e importante referência teórica alternativa para explicação dos processos de escolha das formas organizacionais, na qual as organizações são definidas como um conjunto de contratos que funcionam como "elos" das cadeias produtivas.

Nesta abordagem a firma é um conjunto de contratos, intercâmbios e transações, que envolvem custos: os chamados custos de transação - resultantes da obtenção das informações necessárias à realização de negócios, negociação de acordos e contratos de salvaguarda, entre outros. Segundo Willianson (1985), os custos de transação podem ser determinados como os custos de desenhar e monitorar contratos, ou seja, são os pontos de análise da organização vista como um conjunto de contratos. O conceito de custo de transação é subdividido em dois grupos: os custos gerados antes da transação, ex ante, como a elaboração e negociação dos contratos e a procura e conhecimento da outra parte contratante, e os custos ex post, gerados após a concretização dos negócios, tais como o monitoramento das imposições contratuais, resolução de conflitos, etc.

Além de buscar a maximização de seus lucros, as firmas necessitam minimizar seus custos de transação. Assim, a forma de gerenciar as relações entre os agentes envolvidos para a conquista dos objetivos é cada vez mais importante. Porém, isso não se constitui tarefa fácil pois existem riscos ou incertezas incorridos neste processo, como por exemplo, o comportamento oportunista por parte dos agentes - pois não é possível prever todas as atitudes que podem ser tomadas pelos agentes econômicos. A presença de oportunismo é atribuída às relações econômicas onde pode haver má fé ou engano consciente entre as partes, em geral decorrente da busca de auto-interesse. A incerteza e/ou os riscos dizem respeito à 
limitação cognitiva da mente humana que a impede de avaliar, por exemplo, todas as conseqüências possíveis de uma ação (WILLIANSON, 1985).

As transações que envolvem incertezas sobre seus resultados e requerem investimento em ativos específicos, tenderão a ser internalizadas pela firma (hierarquia). No caso das transações simples, não repetitivas e que não requerem investimento em ativos específicos tenderão a ocorrer através do mercado (transações de mercado).

A presença (e combinação) dessas características nas transações e a maior ou menor intensidade destas, estão na raiz da explicação das formas de organização e coordenação (comando, governança, poder) econômicas. Espera-se que os agentes da rede através de uma estrutura de governança possam buscar a otimização de seus custos de transação. Isso implica em diminuir os riscos e incertezas que caracterizam um processo de transação partindo para uma estrutura de coordenação que estabeleça um conjunto de regras que governem determinadas transações entre os agentes da rede.

Segundo Humphrey e Schmitz (2000), a "governança" pode ser entendida como o "modo de coordenação das atividades interdependentes" ou como o "meio utilizado na coordenação das redes". Outra definição pode ser a "coordenação de atividades econômicas sem o relacionamento com o mercado". Buscar minimizar os custos de transação entre os vários agentes econômicos que compõem uma rede de cooperação significa também buscar a "eficiência coletiva".

Com base na literatura sobre diversos estudos de casos, Humphrey e Schmitz (2000) apontam que existem formas de governança local, pública e privada que podem exercer papel importante para o fomento da competitividade dos produtores aglomerados.

No caso da governança pública, as ações podem ser coordenadas pelo setor público, destacando-se as ações coordenadas pelos governos locais para a 
assistência e promoção dos produtores aglomerados. Dentre essas, as ações de criação e manutenção de organismos voltados à promoção do desenvolvimento dos recursos humanos locais, como centros de treinamento de mão-de-obra, centros de prestação de serviços tecnológicos, agências governamentais de desenvolvimento.

No caso da governança local privada, destaca-se o papel das associações de classe e de agências locais privadas de desenvolvimento. Suzigan et al. (2003) mencionam vários estudos que comprovaram o importante papel dessas instituições como elementos catalisadores do processo de desenvolvimento local através de ações de fomento à competitividade e de promoção do conjunto das empresas. A organização do sistema local também pode se dar por meio da coordenação de uma ou mais empresas líderes. Esta também é uma forma de governança privada. Para expressar esse fenômeno Humphrey e Schmitz (2000) utilizam o termo quasehierarquia quando a presença dessas empresas exercem forte influência sobre as estratégias das demais firmas que compõem a rede ou sistema.

Suzigan et al., (2003:82) compreendem como "promissoras, as medidas que visem estimular ações coletivas (se possível com um agente coordenador); fortalecer as instituições locais privadas e públicas; adequar a infra-estrutura física e o suprimento de serviços especializados (técnicos, tecnológicos, de ensino profissionalizante, de testes, de pesquisa sobre mercados e produtos, etc); intensificar os fluxos de conhecimentos, e fortalecer a capacidade de aprendizado das empresas, sobretudo das micro, pequenas e médias".

Finalmente, entende-se que as possibilidades de desenvolvimento local são dependentes das formas de governança do sistema. Além das economias externas incidentais inerentes à concentração de empresas, outros benefícios dependem da existência de formas de governança do arranjo produtivo local que estimulem a manutenção de relações cooperativas entre os agentes, levando ao estabelecimento de ações conjuntas entre eles e ao incremento da competitividade do conjunto de produtores (SUZIGAN et. al, 2003). 


\subsection{A Cooperação entre os agentes e o Capital Social}

A cooperação é percebida pela literatura como um mecanismo importante de viabilização de vantagens competitivas dinâmicas que explicaria, em parte, as diferenças das vantagens alcançadas por diversas localidades. Este tópico pretende comentar a importância da cooperação como elemento de valor no capital social (conceito que será tratado posteriormente) para o sucesso das redes e para o desenvolvimento local.

A cooperação ou a colaboração, são os termos e conceitos utilizados para explicar ou dar entendimento às relações interorganizacionais (LEON OLAVE e AMATO NETO, 2005).

"Colaboração é um processo através do qual, diferentes partes, vendo diferentes aspectos de um problema, podem, construtivamente, explorar suas diferenças e procurar visões limitadas (...) Colaboração ocorre quando um grupo de "autonomous stakeholders", com domínio de um problema, se envolve em um processo interativo, usando divisão de papéis, normas e estruturas, para agir ou decidir questões relacionadas ao problema" (GRAY e WOOD, 1991 apud LEON OLAVE e AMATO NETO, 2005:69).

A cooperação depende de ação consciente e planejada dos atores locais, e está intimamente relacionada com aspectos sócio-culturais da localidade, que por sua natureza, não são facilmente replicados em outros contextos. Quando presentes, esses aspectos podem trazer ganhos para que as firmas conjuntamente busquem superar obstáculos.

A formação de novos arranjos e estruturas organizacionais baseadas na colaboração e na cooperação entre empresas pode ser uma alternativa para aquelas organizações que se sentem isoladas ou incapazes de acompanhar a dinâmica concorrencial. Desta forma, empresas que muitas vezes não se vêem em condições para competir, colaboram na formação de fusões ou incorporações, franquias e 
outras alianças estratégicas para permanecerem competitivas (MINTZBERG e QUINN, 2001).

Para os pequenos empreendimentos, num ambiente cada vez mais exigente, a cooperação, é percebida como um mecanismo importante de vantagens competitivas dinâmicas e instrumento fundamental para a superação dos limites relacionados ao tamanho destas empresas. A experiência internacional tem demonstrado que a cooperação pode inclusive elevar PME's à condição de motor da economia, ao invés de uma condição marginal de pouca relevância.

Tanto as redes horizontais como as verticais permitem ações cooperativas, que tornam possível a criação de um espaço de aprendizagem coletiva, onde idéias são trocadas e desenvolvidas e conhecimento compartilhado numa tentativa de melhorar a qualidade de produtos e processos, ocupação de segmentos mais lucrativos, realização e resolução de problemas (LEON OLAVE, 2003). Entretanto, o comportamento cooperativo só gera resultados se ocorrer interação e ação que estimule e facilite o processo de aprendizado dos agentes, uma vez que o aprendizado não ocorre apenas pela cooperação, pois os transbordamentos são incidentais e geram tais resultados independemente de ações deliberadas.

Como qualquer transação econômica envolve riscos, a confiança nas relações de negócios é fundamental. Ela é um dos fatores que promovem a redução dos custos de transação e torna a existência das redes economicamente viável, uma vez que em atmosfera de confiança, os problemas são resolvidos com maior eficiência porque a informação e know-how são trocados mais livremente (BOSS, 1978 apud BALESTRIN e VARGAS, 2004).

Diversos autores (HUMPHREY e SCHMITZ, 1998; SCHMITZ, 1999; RABELOTTI, 1995) têm explorado este tema, e diversos são os enfoques. Humprey e Schmitz (1998) abordam um aspecto interessante do relacionamento em redes: o uso de sanções que penalizam as empresas e as obrigam a agirem corretamente, mas que também criam incentivos, o que pode se tornar uma alternativa para se lidar com os riscos. A outra alternativa refere-se às relações de confiança entre os 
atores. As sanções dão garantias (por escrito) que será cumprido o combinado. Desta forma, as firmas ficam menos vulneráveis ao risco, numa relação de confiança mútua (ainda que mínima). Por outro lado, a confiança só existe em relações com um nível maior de interação e interdependência. A idéia é que os conceitos de sanções e confiança, trabalhados em conjunto, promovam uma alternativa para gerar formas de relacionamento e cooperação dentro da rede. Se as sanções reduzem os riscos associados à confiança, por outro lado, o difundido uso da confiança nos relacionamentos cria necessidade por sanções para conter os riscos envolvidos.

Segundo Humphrey e Schmitz (1998), para se alcançar o tipo de relacionamento colaborativo, é necessário o estabelecimento de sanções, desde o nível macro (políticas do Estado) até o nível micro (ações conjuntas de empresas). As sanções e a confiança podem se apresentar em três níveis (tabela 2.1)

Tabela 2.1 - Sanções e Confiança

\begin{tabular}{|cll||}
\hline NíVEL & \multicolumn{1}{c|}{ SANÇÕES } & \multicolumn{1}{c|}{ CONFIANÇA } \\
Macro & $\begin{array}{l}\text { Provisões contratuais que servem } \\
\text { para a maioria dos acordos }\end{array}$ & $\begin{array}{l}\text { Baseada em certificações e } \\
\text { informações obtidas em banco } \\
\text { de dados }\end{array}$ \\
Médio & $\begin{array}{l}\text { Regulações setoriais e perda de } \\
\text { reputação no grupo (acordos } \\
\text { entre setores) }\end{array}$ & $\begin{array}{l}\text { Baseada na reputação e nas } \\
\text { competências (confiança } \\
\text { baseada em características) }\end{array}$ \\
& $\begin{array}{l}\text { Personalizado para cada relação, } \\
\text { penaliza comportamentos } \\
\text { Mportunistas com a perda de } \\
\text { benefícios futuros do }\end{array}$ & $\begin{array}{l}\text { Baseada em relações de } \\
\text { parcerias passadas } \\
\text { (experiências de relações de } \\
\text { relacionamento }\end{array}$ \\
\hline
\end{tabular}

Fonte: Humphrey e Schmitz, (1998:36)

A provisão de agentes de coordenação é crucial para o processo de funcionamento da rede. Mediadores podem colaborar para superar a desconfiança, facilitando o acesso ao suporte do Estado, que por sua vez, oferece credibilidade ao programa e oferece recompensas aos participantes (HUMPHREY e SCHMITZ, 
1998). Assim, é um grande desafio estruturar e coordenar serviços de mediação para estabelecer relacionamento efetivo entre empresas no nível micro, ou seja, relacionamentos que ultrapassem o grau de "confiança mínima" (simples transações) para um grau de "confiança estendida" (relacionamentos/transações mais complexas). O desejável é que isso leve a um círculo virtuoso de práticas de ações conjuntas que tragam eficiências coletivas e proporcionem o fortalecimento da confiança estendida.

Outra abordagem importante sobre o contexto sócio-cultural como relevante para os aglomerados é a de Becattini (1990). A principal contribuição deste trabalho, que se baseou nas experiências dos distritos industriais italianos, é o destaque à necessidade de se analisar os aglomerados como uma junção de fatores econômicos e sócio-culturais que determinam as vantagens e as desvantagens competitivas das empresas ali localizadas, e que, portanto, não podem ser dissociadas, já que são interdependentes.

A partir da visão de Beccatini, o contexto econômico e sócio-cultural das firmas é essencial para o seu comportamento. Assim, "se as empresas de um aglomerado se inserirem no mercado para competir via preço, em que a luta entre concorrentes é bastante acirrada, existirá um espaço bastante reduzido para interação e cooperação horizontal deliberada entre as empresas" (MOTTA, 2006:27).

Para Schmitz (1999) as ações conjuntas são de dois tipos - empresas individuais que cooperam (por exemplo, desenvolvendo novos produtos, emprestando equipamento, etc.) ou grupos de firmas que unem forças em associações setoriais, consórcio de produtores etc. Ele também faz outra distinção, entre ações que envolvem apenas um setor (horizontais) e aquelas que envolvem mais de um setor (verticais). Assim, são 4 as classes resultantes do cruzamento destas duas dimensões de classificação (tabela 2.2). 
Tabela 2.2 - Formas de ações conjuntas em clusters de empresas

\begin{tabular}{|l|c|c|}
\hline & BILATERAIS & MULTILATERAIS \\
\hline HORIZONTAIS & $>\begin{array}{l}\text { Troca de } \\
\text { Equipamentos e } \\
\text { Informações }\end{array}$ & $>\begin{array}{l}\text { Associações de } \\
\text { Produtores }\end{array}$ \\
\hline VERTICAIS & $>\begin{array}{l}\text { Relações Usuário- } \\
\text { Produtor }\end{array}$ & $\begin{array}{l}\text { Alianças ao Longo } \\
\text { da Cadeia } \\
\text { Produtiva }\end{array}$ \\
\hline
\end{tabular}

Fonte: Schmitz, 1999.

As formas de ações conjuntas podem ser descritas da seguinte maneira:

1. Cooperação bilateral vertical - empresas com interesses convergentes que se unem para através da cooperação alcançar objetivos comuns. Tipicamente utilizada por empresas inovadoras que buscam, através da cooperação, diminuir os ciclos de inovação e assim conquistarem vantagens competitivas para sua atuação no mercado.

2. Cooperação horizontal bilateral - este tipo de cooperação ocorre quando se verificam fortes relações de confiança entre as empresas e também quando é possível definir claramente o objetivo da cooperação e a repartição dos resultados decorrentes destas ações. Tipicamente empregada por empresas concorrentes que se juntam para desenvolver um trabalho específico em conjunto. A desconfiança em relação a comportamentos oportunistas pode minar as tentativas de cooperação horizontal bilateral.

3. Cooperação multilateral horizontal ocorre quando organismos públicos ou privados coordenam projetos setoriais que envolvem a participação de várias empresas concorrentes. Em tais situações é possível que a presença de um organismo local que coordene as ações e as relações entre as empresas iniba comportamentos oportunistas, aumentando as chances de sucesso das iniciativas. Esse organismo pode ser um sindicato ou uma associação de empresas e deve ter credibilidade entre os agentes locais.

4. Cooperação multilateral vertical ocorre quando instituições e empresas pertencentes à cadeias produtivas diferentes têm relações verticais. Para que ocorra 
este tipo de cooperação, é importante a existência de instituições de apoio aos setores fortes, bem articuladas e que tenham interesses em comum bem definidos.

Mais recentemente tem sido difundido na literatura econômica o termo capital social, que surgiu originalmente no âmbito da sociologia, para expressar o reconhecimento e a valorização de que os atores econômicos encontram-se imersos (embedded) em estruturas e redes sociais. Portanto, para melhor compreender e intervir sobre a dinâmica econômica, é preciso considerar a estrutura e as relações sociais em que a mesma ocorre (ALBAGLI e MACIEL, 2002).

Embora haja importantes autores de referência sobre capital social (James Coleman, Pierre Bourdieu), Robert Putnam foi importante para popularizar este conceito. O autor define capital social como "traços da vida social, ou seja, redes, normas e confiança, que facilitam a ação conjunta em prol de objetivos comuns" (PUTNAM, 2002). Ele destaca a confiança como sendo um lubrificante da vida social, sendo esta alcançada a partir do conhecimento mútuo entre os membros da comunidade e de uma forte tradição de ação comunitária.

Embora na literatura sobre aglomerações produtivas seja pouco discutido o tema do capital social, os componentes deste conceito (confiança, valores compartilhados, compromisso, relacionamentos) que contribuem para os processos de inovação e de aprendizado interativos, de criação e de intercâmbio de conhecimento e habilidade, têm sido amplamente discutidos.

\subsection{Políticas Públicas de promoção e desenvolvimento de aglomerados produtivos e redes de cooperação}

Um dos principais pontos de convergência nas discussões sobre políticas de promoção das PME's, é de que as aglomerações produtivas locais confere-lhes de fato vantagens positivas. 
As políticas públicas em seus níveis de poder (municipal, estadual e federal) voltadas à promoção dos arranjos produtivos e redes de cooperação podem e devem ser instrumentos para fomentar desenvolvimento local sustentável (econômico, social e ambiental). As políticas voltadas para geração de demanda, e que são implementadas em consonância com agentes locais, apresentam grande possibilidade de gerar vantagens para as firmas envolvidas.

As políticas de apoio à cooperação entre PME's devem ser seletivas e adaptadas a cada contexto específico. Seus objetivos devem encorajar o uso da cooperação não como finalidade, mas instrumento (EUROPEAN COMISSION, 2004). LASTRES et al. (2003:543) ressaltam que "o foco em arranjo produtivo local não deve ser visto em si como prioridade de política, mas sim como um formato que potencializa as ações de promoção por focalizar agentes coletivos e seus ambientes, suas especificidades e requerimentos".

Segundo Humprhey \& Schmitz (1998), as políticas públicas devem estimular o fortalecimento das empresas dos clusters buscando aproximar as firmas de clientes potenciais (apoio na participação de feiras, direcionamento de demandas do setor público, desenvolvimento de contratos de fornecimento para grandes empresas), e não como tem ocorrido na maioria dos estudos de casos analisados, cuja política de fomento destinada às empresas se orientam para melhorar as condições de oferta (treinamento, crédito, matérias-primas, tecnologia, etc.). As políticas devem ser organizadas para atender os interesses coletivos das firmas, e acumular melhorias competitivas.

Dentre as razões que dificultam a implementação de políticas bem sucedidas para a promoção de micro, pequenos e médios negócios, destacam-se inadequações dos mecanismos e instrumentos, superposição e descoordenação de ações, as quais não têm continuidade. Equivocadas não são as especificidades dessas empresas, mas sim as ações e instrumentos que não conseguem dar conta das mesmas (LASTRES et. al., 2003).

Casarotto Filho e Pires (2001:130) propõem um plano de ação de promoção e desenvolvimento regional (figura 2.1), que contemple mecanismos de continuidade e 
o estabelecimento de um fórum ou agência de desenvolvimento regional (ADR). "Os fóruns são importantes mecanismos de fomento à cooperação, mas as execuções das ações decididas necessitam de uma estrutura profissionalizada, sob pena de suas reuniões se converterem em mera terapia grupal”.

Por esse motivo é que é proposto as ADR's, para servirem de braço operacional dos fóruns de discussão que devem ter como objetivo articular e gerenciar projetos com vários parceiros. Esses projetos podem e devem contar com a habilidade de várias instituições, entre elas, bancos de desenvolvimento, universidades, instituições de apoio à pequenas empresas, associações comerciais e industriais, associações de municípios, etc.

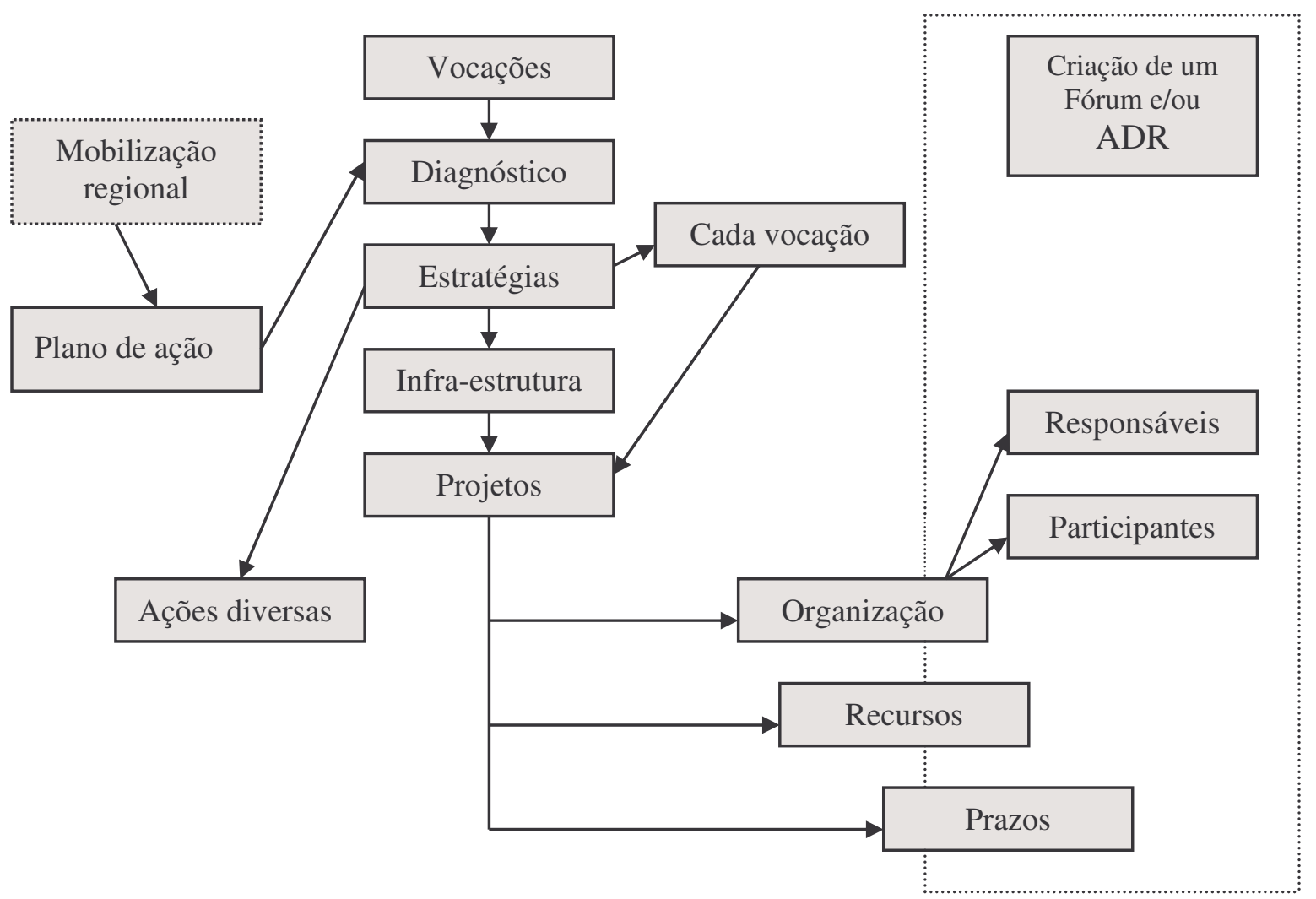

Figura 2.1 - Esquema para Plano de Ação Regional: modelo ideal teórico Fonte: Casarotto Filho e Pires (2001, p.127)

É proposto pelos autores Casarotto Filho e Pires (2001) que uma ADR nasça como um consórcio entre essas instituições e trabalhe em conjunto agregando as 
competências em forma de parceria público-privada. O plano proposto deve conter um diagnóstico (baseado na vocação regional), definição de estratégias para a região, projetos decorrentes das estratégias e ações diversas, além da organização (responsáveis e participantes de cada projeto), recursos e prazos.

Dentre as oportunidades para a implementação de políticas de promoção de APLs, destacam-se aquelas associadas à necessidade de buscar novos caminhos para o desenvolvimento do Brasil e seu reposicionamento no cenário crescentemente competitivo e globalizado (LASTRES et. al., 2003).

\subsection{Principais Tipologias de Aglomerados Produtivos e Redes de Empresas}

$\mathrm{Na}$ literatura, em virtude das várias vertentes teóricas em aglomerações produtivas, surgem diferentes conceitos sobre as concentrações geográficas, mas muitas vezes com significados semelhantes. Distritos industriais, meios inovadores, arranjos produtivos locais (APL's), sistemas produtivos locais (SLP's), sistemas locais de inovação, parques tecnológicos, clusters regionais e setoriais, entre outras denominações, apresentam como ponto comum como os ganhos de eficiência coletiva que podem ser alcançados através da combinação de economias externas (incidentais, não planejadas) com economias obtidas por ações conjuntas deliberadas (CASSIOLATO e SZAPIRO, 2002).

Alguns autores (AMATO NETO, 2000, BRITO, 2002) já enumeraram e descreveram as diferenças entre essas formas de organização de empresas; entretanto definir tais estruturações não é tarefa trivial, nem imune de controvérsias.

Parte deste capítulo procura apresentar as principais formas de aglomerações produtivas industriais, com relevância para os países em desenvolvimento, formadas por micro, pequenas e médias empresas. 
Embora, as terminologias contemplem abordagens teóricas diferentes, existe uma considerável convergência de idéias com relação à dimensão espacial da inovação e da competitividade (LEMOS, 2003). A seguir serão apresentadas as principais tipologias de aglomeração e redes de empresas.

\subsection{Distritos Industriais}

O conceito original de distrito industrial foi cunhado por Marshall (1920), referindo-se aos distritos industriais britânicos. Esta denominação é dada por ele às aglomerações geográficas e setoriais de pequenos e médios produtores, que se destacam pelo alto grau de especialização produtiva e interdependência, pela alta flexibilidade, fácil acesso à mão-de-obra qualificada, venda de produtos ao mercado internacional e um sistema de troca de informações técnicas e comerciais entre agentes.

Humphrey (2003, p. 2) define distritos industriais como "redes de pequenas empresas que estão ligadas em conjunto por meio da divisão do trabalho e especialização, de modo que leva ao enriquecimento de "capabilities" (ou competências) coletivas, economias de escala e escopo.

Este tipo de aglomeração representa o oposto dos modelos tradicionais baseados no modelo de organização fordista, dada as características de flexibilidade e estreita integração entre as empresas e o ambiente social e cultural (PIORE e SABEL, 1984).

Vários autores (BECCATINI e RULANI, 1996; SENGENBERGER e PYKE, 1992; BRUSCO, 1992; BRUSCO et. al, 1996) destacaram a idéia de que os distritos industriais podem ser considerados "completos" processos produtivos, ou um "quase completo" processo produtivo. Nos distritos industriais italianos a divisão do trabalho entre os pequenos produtores é capaz de promover economias de aglomeração que não estariam disponíveis caso as empresas estivessem atuando de forma isolada. Chama a atenção o bom nível de cooperação entre firmas presentes nestes locais. 
Os diversos estudos desenvolvidos, a partir da experiência de outros países, contribuíram para definir vários atributos aos distritos industriais (SOUSA, 2005, p. 11): i) proximidade geográfica; ii) especialização setorial; iii) predominância de pequenas e médias empresas; iv) estreita colaboração entre firmas; v) competição entre firmas; vi) identidade sócio-cultural com confiança; vi) organizações de apoio; vii) promoção de governos regionais e municipais. Tais características contribuem para que as empresas de pequeno porte desenvolvam ações cooperativas e integradas que se traduzem em inserção ativa no mercado.

De uma forma geral, identificam-se três tipos básicos de empresas dentro dos distritos industriais: i) aquelas que suportam as atividades produtivas; ii) aquelas que são fornecedoras de produtos intermediários para outras firmas; iii) e aquelas que produzem o produto final (bens de consumo) para o sistema de varejo ou para outras empresas que usam os produtos (como quase sempre ocorre no caso de bens de capital) (BRUSCO, 1992 apud HUMPHREY, 2003).

No Brasil, o termo distrito industrial é freqüentemente utilizado para designar determinadas localidades e/ou regiões definidas para a instalação de empresas, muitas vezes contando com a concessão de incentivos governamentais (LASTRES e CASSIOLATO, 2004). Raramente apresentam características que promovam a cooperação, significando na maioria dos casos apenas um "conjunto de lotes de empresas de vários ramos" com um local de instalação comum (MEYER-STAMER, 2001, p.6).

Originalmente, os diversos atores que se dedicaram aos estudos dos distritos industriais não manifestaram preocupação com o processo inovativo ou aspectos relacionados à inovação. Entretanto, mais recentemente, parece haver um reconhecimento por parte desses autores de que a inovação, e os demais aspectos relacionados à ótica evolucionista, podem constituir diferencial à sobrevivência, continuidade e sucesso de um distrito qualquer (SOUSA, 2005). 


\subsection{Clusters regionais}

Os clusters são caracterizados pela concentração de empresas (geralmente pequenas e médias) de um mesmo setor em uma mesma região geográfica. No inglês tem o significado de um grupo de coisas próximas, podendo ser traduzido para o português como "aglomerado".

Os primeiros estudos relacionados ao conceito de cluster foram empreendidos por KRUGMAN (1991), que, baseado nos estudos de Marshall, procurou identificar a natureza das externalidades que levam à concentração de uma indústria em particular. Entretanto, em suas análises destacou mais a geração de economias externas do que a concentração das empresas, chegando `a conclusão de que a formação do cluster estaria associada somente a "geografia econômica", a qual definiu como a simples concentração geográfica de empresas em uma determinada região.

Com o objetivo de tentar explicar a competitividade das firmas e dos países a partir de aspectos locacionais, Porter (1999, p.211-216), associou a existência de clusters a fatores virtualmente econômicos de caráter nacional, regional e metropolitano. Segundo este autor o cluster corresponde: “... a um agrupamento geograficamente concentrado de empresas inter-relacionadas e instituições correlatas numa determinada área, vinculadas por elementos comuns e complementares, cujo todo é maior do que a soma das partes. Ocorrem em muitos tipos de setores, em campos maiores e menores e mesmo em alguns negócios locais. Estão presentes em economias grandes e pequenas, em áreas rurais e urbanas e em vários níveis geográficos (países, estados, regiões e cidades)".

Porter enfatizou a importância de cinco fatores para a competitividade: i) rivalidade entre empresas e condições de entrada de concorrentes; ii) papel de fornecedores de equipamentos e outros insumos; iii) ameaça de produtos substitutos; iv) importância dos diferentes fatores de produção; v) e condições da demanda. Em suas análises, este autor colocou maior ênfase no aspecto da rivalidade/concorrência como estimuladores da competitividade entre as empresas 
do que nos processos de cooperação, aprendizado e capacitação. Com a introdução da noção de eficiência coletiva, Schmitz (1995) descreve os ganhos competitivos associados à interação entre as empresas locais, enriquecendo a abordagem dos clusters.

Outro conceito encontrado na literatura é de que os clusters referem-se a muitas formas organizacionais. Cada forma apresenta uma trajetória única de desenvolvimento, princípios organizacionais e problemas específicos. Podem se originar como aglomerações espontâneas das firmas ou a partir da indução de agentes locais e através de políticas públicas (FARINELLI e MYTELKA, 2000).

Amato Neto (2000, p. 53-54) afirma que "clusters são formados apenas quando ambos aspectos, setorial e geográfico, estão concentrados. De outra forma o que se tem são apenas organizações de produção em setores e geografia dispersa, não formando, portanto, um cluster (...)". No caso de um cluster há amplo escopo para a divisão de tarefas entre empresas, bem como para a especialização e inovação, elementos essenciais para a competição além de mercados locais. Há também espaço significativo para ação conjunta entre as empresas, o que não ocorre em sistemas dispersos.

Para os especialistas da Comissão Européia (EUROPEAN COMMISSION, 2002), os clusters são grupos de empresas independentes e de instituições associadas que são: i) de natureza competitiva e colaborativa; ii) geograficamente concentradas em uma ou mais regiões; iii) especializadas em uma área específica, integradas por tecnologias e habilidades comuns; iv) que podem ser tradicionais ou de base tecnológica; v) podem ser institucionalizados ou não. A Comissão Européia (EUROPEAN COMMISSION, 2002a, p. 14) propõe uma hierarquia de três conceitos para os clusters (tabela 2.3). 
Tabela 2.3 - Clusters: uma hierarquia de três conceitos

\begin{tabular}{|c|c|}
\hline Conceitos & \multicolumn{1}{|c|}{ Definições e Diferenças } \\
\hline Cluster regional & $\begin{array}{l}\text { Concentração de firmas interdependentes dentro de um } \\
\text { mesmo ou adjacente setor industrial em uma limitada área } \\
\text { geográfica }\end{array}$ \\
\hline $\begin{array}{c}\text { Rede regional de } \\
\text { inovação }\end{array}$ & $\begin{array}{l}\text { Mais organizada cooperação entre empresas, estimulada } \\
\text { pela confiança, normas, princípios, os quais encorajam as } \\
\text { empresas a executarem atividades de inovação }\end{array}$ \\
\hline $\begin{array}{c}\text { Sistema regional de } \\
\text { inovação }\end{array}$ & $\begin{array}{l}\text { Cooperação entre empresas e diferentes organizações para } \\
\text { o desenvolvimento e difusão do conhecimento }\end{array}$ \\
\hline
\end{tabular}

Fonte: European Commission (2002a, p.14)

Humphrey e Schmitz (1998) ao tratarem dos clusters destacam aspectos da cooperação, afirmando haver uma alta taxa de transações entre as empresas e que estas se engajam freqüentemente em cooperação horizontal e vertical. Como a dependência mútua é alta, a exposição ao oportunismo também é alta, particularmente onde os fornecedores fazem investimentos específicos em transações e produtores finais contam com fornecedores em sua capacidade de atender as rígidas especificações e a produção com alta qualidade.

Meyer-Stamer (2001) recomenda que sejam conhecidas as diferenças entre tipos distintos de clusters para que sejam concebidas promoções específicas e adequadas. Para o autor existem três tipos de clusters: i) cluster de sobrevivência: setor informal da economia e constituído por micro e pequenas empresas de subsistência com capital social modesto, desconfiança entre empresas, concorrência ruinosa e pouca atividade inovativa; ii) cluster fordista: aglomerações de micro e pequenas empresas com alto potencial de desenvolvimento (dominadas por grandes empresas) onde ainda predomina o modelo de produção fordista em grande escala, mas tendem a passar por uma adaptação de especialização flexível; iii) $\underline{\text { cluster }}$ transnacional: contribui para o desenvolvimento de fornecedores, como forma de investimento em países em desenvolvimento, geralmente resultado de estratégias alteradas de empresas transnacionais. 
A literatura existente sobre clusters apresenta um vasto leque de explicações sobre sua formação e desenvolvimento, porém nem sempre explica a razão pela qual, clusters específicos surgem em determinados locais. De acordo com Porter (1998), os fatores condicionantes para a formação de clusters, são: as condições de demanda, as relacionadas indústrias de apoio, a estratégia da firma, sua estrutura e o nível de rivalidade presente no ambiente local. Para Bollinger et al. (1983), no caso de aglomerações de alta tecnologia, as pré-condições para a sua formação e desenvolvimento, são: a presença de universidades, aeroportos internacionais, disponibilidade de capital de risco, mão de obra qualificada, entre outros.

Andriani et. al (2005) apresentam uma síntese das principais características dos clusters mencionadas até aqui pelos autores: i) massa crítica de empresas e instituições localizadas em uma mesma área geográfica e especializada em um conjunto de atividades econômicas interdependentes; ii) firmas especializadas em diferentes aspectos da cadeia de valor; devido a complementaridade existente, as empresas são integradas por uma divisão externa de trabalho resultando em redes de relacionamento de entradas e saídas (input-output links); iii) empresas que são incorporadas (embedded) em uma densa rede de interdependência (social e cultural) não usual que gera oportunidades para aprendizado mútuo e eleva o nível de cooperação; iv) processo de tomada de decisão relativamente distribuído, o qual não apresenta características claramente hierárquicas; v) existência de instituições e organizações públicas e privadas capazes de dar suporte ao crescimento dos clusters disponibilizando serviços e iniciativas.

Os clusters são características marcantes de praticamente todas as economias, principalmente nos países desenvolvidos, como exemplo, o Vale do Silício, no estado da Califórnia nos EUA. Uma grande discussão em torno dos clusters industriais e que divide os economistas se refere à dificuldade destes, particularmente nos países em desenvolvimento, de se integrarem às cadeias globais de produção, indo além das esferas de produção, ficando assim limitados de acessar etapas de maior conteúdo e de agregação de valor. O conceito de clusters buscou desenvolver um referencial próprio para as especificidades que marcam o crescimento e inserção competitiva de aglomerações nos países em 
desenvolvimento (VARGAS, 2002), inicialmente com foco nos ganhos gerados pelas interações entre empresas locais, através do conceito de eficiência coletiva.

Por muito tempo, a análise da literatura sobre clusters ficou centrada na natureza dos vínculos de cooperação horizontal e vertical inter-firmas, sem levar em conta a importância das relações com atores externos na definição das estratégias das aglomerações. Entretanto, tem-se observado avanços na literatura no sentido de estudar o impacto de vínculos externos no processo de melhorias de produtores locais nos países em desenvolvimento, assim como aprofundar a discussão sobre a influência das formas de governança, aspectos da inovação e tecnologia, ainda que de modo simplificado (LASTRES e CASSIOLATO, 2004).

\subsection{Millieu Inovateur - Ambiente inovador}

O conceito de Millieu Inovateur foi desenvolvido por iniciativa de um grupo de acadêmicos do GREMI (Groupement de Recherche Européen sur les Millieux Inovateurs), na década de 80, com o objetivo de analisar o papel do ambiente no processo de desenvolvimento tecnológico. Este conceito enfatiza a importância do ambiente local no dinamismo tecnológico e focaliza as relações criadas entre os diferentes agentes que fomentam a formação de um ambiente inovador, onde a firma não é considerada um agente isolado no processo de inovação, mas parte de um ambiente com capacidade inovativa. Esses processos são acionados pela lógica de interação e a dinâmica de aprendizagem (LASTRES e CASSIOLATO, 2004).

A abordagem dos millieux inovateurs destaca a criatividade e a inovação contínua como resultados de um processo de aprendizado coletivo. A proximidade geográfica é fundamental, não apenas pelas economias incidentais, mas fundamentalmente pela facilidade de troca de informações, similaridades de atitudes culturais e psicológicas, contatos interpessoais e cooperação, capacidade inovativa, mobilidade e flexibilidade de fatores nos limites do local (LEMOS, 2003). 
A chave dos millieux inovateurs, segundo Maillat (1995) apud Florian (2005) está centrada na capacidade dos atores em compreender as transformações ao seu redor, no ambiente tecnológico e mercadológico, para que eles façam evoluir e transformar o seu ambiente inovador.

\subsection{Cadeias produtivas}

O conceito de cadeia produtiva pode ser entendido como o encadeamento ou seqüência de atividades econômicas interdependentes pelas quais passam e são transformados e transferidos os diferentes insumos (matéria-prima, máquinas e equipamentos, produtos intermediários até os finais, distribuição e comercialização). $\mathrm{Na}$ cadeia produtiva há forte especialização dos agentes em etapas distintas do processo produtivo, dada forte divisão de trabalho. Pode ser caracterizada como sendo de âmbito local, regional, nacional e mundial. Assim, um arranjo produtivo pode conter uma cadeia estruturada localmente ou de maior abrangência espacial (LASTRES e CASSIOLATO, 2004).

Há algumas décadas, as grandes empresas vêm desverticalizando suas estruturas corporativas e concentrando-se nas atividades de maior valor agregado. Assim, estas grandes empresas subcontratam, muitas vezes nos países em desenvolvimento, os serviços produtivos, e buscam firmas localizadas em aglomerados, devido às vantagens trazidas pela concentração. Desta forma, as grandes empresas, líderes das cadeias produtivas globais, fomentam a internacionalização das firmas dos arranjos produtivos (MOTTA, 2006).

As cadeias de maior abrangência, ou cadeias globais de produção apresentam-se em dois tipos (GEREFFI, 1998): i) tipo producer-driven commodity chains : cadeias comandadas por produtores; ii) buyer-driven commodity chains: cadeias comandadas pelos compradores. Tais cadeias possuem as seguintes dimensões: 
- Estrutura de input-output, ou seja, conjunto de produtos e serviços conectados numa seqüência de atividades que adicionam valor econômico;

- Territorialidade, ou seja, produção e redes de marketing dispersas ou concentradas espacialmente, compreendendo firmas de diferentes tipos e tamanhos;

- Estrutura de Comando, ou seja, relações de poder e autoridade que decidem como os recursos financeiros, materiais e humanos são alocados num fluxo dentro de uma cadeia.

A abordagem de cadeia produtiva tem provado a sua utilidade para organizar a análise e aumentar a compreensão da complexidade dos macroprocessos de produção, bem como examinar desempenho desses sistemas, determinar gargalos ao desempenho, oportunidades não exploradas, processos produtivos, gerenciais e tecnológicos.

A eficiência de uma determinada cadeia produtiva está diretamente relacionada à sua coordenação, motivo pelo qual deve-se dispensar grande importância aos aspectos relacionais entre os diversos elos da cadeia.

\subsection{Arranjos e Sistemas Produtivos Locais}

A abordagem de arranjos ou sistemas produtivos locais parte de um conceito amplo de aglomeração produtiva, englobando todos os tipos referidos na literatura (distritos, clusters, pólos industriais, entre outros), focalizando, entretanto, "um conjunto específico de atividades econômicas que possibilite e privilegie a análise de interações, particularmente aquelas que levem à introdução de novos produtos e processos - que apresentam vínculos mesmo que incipientes" (CASSIOLATO e LASTRES, 2003, p.24). Este é o enfoque evolucionista de inovação e mudança tecnológica em que a especialização e a competitividade econômica são interpretadas dentro de uma perspectiva de interações locais. 
O conceito de "arranjos produtivos locais" é visto como um produto histórico do espaço social local, sendo que alguns podem, eventualmente, não progredir ou evoluir em direção às formas mais sistêmicas de organização produtiva local, e outros, ao contrário, podem desenvolver formas organizacionais como verdadeiros sistemas produtivos inovativos locais (FLORIAN, 2005). Estes últimos podem ser caracterizados como “(...) aglomerados de agentes econômicos, políticos e sociais, localizados em um mesmo território, operando em atividades correlacionadas e que apresentam vínculos expressivos de articulação, cooperação e aprendizagem. Incluem-se não apenas empresas - produtores de bens e serviços finais, fornecedoras de insumos e equipamentos, prestadoras de serviços, comercializadoras, clientes, etc e suas variadas formas de apresentação e associação - mas também diversas outras instituições públicas e privadas voltadas à formação e treinamento de recursos humanos, pesquisa, desenvolvimento, engenharia, promoção e financiamento" (VARGAS, 2002, p.10).

Assim, a ênfase em sistemas e arranjos produtivos locais, fundamentada na visão evolucionista de inovação e mudança tecnológica destaca que (CASSIOLATO e LASTRES, 1999):

i) a inovação e o conhecimento são reconhecidamente os elementoschave da dinâmica e do crescimento, seja de países, regiões ou organizações;

ii) a inovação e o aprendizado são processos dependentes de interações e, portanto, fortemente influenciados por contextos econômicos, sociais, institucionais e políticos específicos;

iii) são profundas as diferenças entre as agentes na capacidade de aprendizado, a qual depende de aprendizados anteriores;

iv) informações e conhecimentos codificados apresentam condições crescentes de transferência - dada a eficiente difusão das tecnologias de informação e os conhecimento tácitos possuem papel primordial para o sucesso inovativo e permanecem difíceis (senão impossíveis) de serem transferidos. 
Está também implícito nesta abordagem conceitos que enfatizam os aspectos regionais e locais, como: aprendizagem, interações, cooperação, competências, complementaridades, seleção, path-dependencies (a trajetória), governança, entre outros.

$\mathrm{Na}$ análise de diferentes arranjos produtivos locais industriais, verifica-se diferenças no seu padrão de comportamento, em geral, bastante diverso um em relação ao outro, o que pode estar relacionado à diferentes estágios de maturidade dos arranjos, variando de rudimentares aos mais complexos e articulados (MACHADO, 2003). As trajetórias desses arranjos dependem de sua história, evolução, organização institucional, contextos sociais e culturais nos quais se insere, estrutura produtiva, organização industrial, tipos de governança, formas de aprendizado e grau de difusão do conhecimento especializado local.

Considerando os dois termos, pode-se dizer que os arranjos produtivos locais não são plenamente constituídos enquanto que os sistemas produtivos locais são aglomerações produtivas especializadas do "tipo ideal", contendo uma forte capacidade endógena para a geração de inovações. Como as trajetórias de crescimento dos arranjos são bastante diferenciadas, um dos componentes importantes para o sucesso destes é o desenvolvimento do capital social, particularmente, a relação de confiança entre os agentes, manifestas em ações conjuntas.

Dentro da estrutura organizacional de um arranjo produtivo, podem surgir algumas variantes. A tabela 2.4 demonstra uma tipologia aos sistemas locais dos autores (SUZIGAN, et. al, 2003), que envolve a combinação de duas variáveis:

i) a importância da atividade econômica para a região (mensurada através do índice de especialização); 
ii) a importância da região para o setor (mensurada pela participação da microregião no total).

Tabela 2.4 - Tipologia de Sistemas Locais de Produção de Acordo com a sua Importância para a região

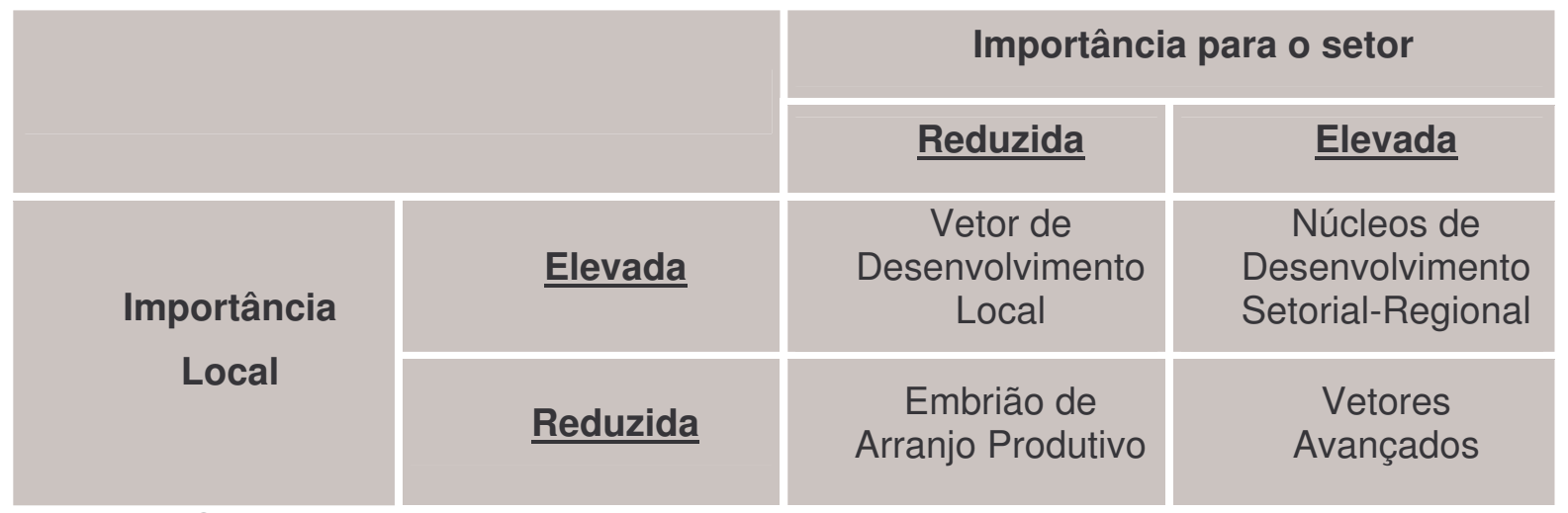

Fonte: Suzigan, et. al, (2003)

A terminologia Núcleos de Desenvolvimento Setorial-Regional é atribuída quando é dupla a importância dos sistemas produtivos para uma região e para o setor a que pertencem. Ao lado destes, existem os Vetores Avançados, que possuem grande importância para o setor (manifestada na participação da produção e no emprego), entretanto, estão dissolvidos num espaço econômico muito maior e com mais diversificação. Isto significa que são importantes para o setor, mas não para o desenvolvimento regional. O termo Vetor de Desenvolvimento Local é dado, caso os sistemas produtivos sejam importantes para uma região, mas não para um setor. E se o sistema é caracterizado pela reduzida importância para o seu setor, além de conviver com outras atividades econômicas na mesma região, este tipo constitui um Embrião de Arranjo Produtivo.

Por estarem baseadas no reconhecimento das especificidades dos diferentes arranjos, as políticas para sua promoção são incompatíveis com modelos genéricos que utilizam idéias de benchmarking e best practices (CASSIOLATO e LASTRES, 2003).

Portanto, o termo APL foi desenvolvido para estudos e análises da realidade de países como o Brasil, onde a heterogeneidade entre as diferentes regiões é uma 
importante variável explicativa das trajetórias de desenvolvimento locais, pois estudos empíricos de países desenvolvidos e com características substancialmente divergentes do Brasil não permitiam aprofundar o conhecimento sobre a realidade local dos países em desenvolvimento (ENDERLE et al.,2005).

As políticas de promoção de APL's não devem ser implementadas de forma isolada, mas devem representar os rebatimentos locais dos setores, cadeias produtivas e demais prioridades elencadas por um projeto de desenvolvimento nacional de longo prazo (CASSIOLATO e LASTRES, 2003).

\subsection{Redes de cooperação entre empresas}

O interesse que o conceito de estruturas em rede vem despertando na literatura, nos estudos e pesquisas, decorre, em boa medida, pela sua maleabilidade. As redes se constituem em quadro de referência que pode ser aplicável à investigação de múltiplos fenômenos caracterizados pela densidade de relacionamentos cooperativos entre os agentes (BRITTO, 2002). Inclusive de fenômenos que não estejam geograficamente circunscritos.

Cada rede tem uma configuração particular. Depende do ambiente onde se forma e atua, da cultura política dos membros, dos objetivos e valores compartilhados. Elas podem ser encontradas em diversos formatos: locais, globais, centralizadas, horizontais, etc. e, são vistas como solução viável às pequenas e médias empresas que se encontram em desvantagem frente às grandes empresas para competir num mercado globalizado. Através das redes de cooperação as PME's podem adquirir maior confiabilidade junto a seus clientes e ampliam o poder de negociação com as grandes empresas (AMATO NETO, 2005).

O nascimento, a sobrevivência e o fim das redes dependem de três requisitos essenciais (CORRÊA, 1999, CASAROTTO FILHO e PIRES, 1999): 
i) a cultura da confiança: refere-se aos aspectos relacionados à cooperação entre as empresas, envolvendo aspectos culturais, aspectos de interesse de pessoas e empresas, ética e respeito comuns.

ii) a cultura de competência: relaciona-se às competências essenciais de cada parceiro, envolvendo aspectos materiais (instalações e equipamentos), como aspectos imateriais (know how).

iii) a cultura da tecnologia da informação: diz respeito aos fluxos de informações, envolvendo aspectos ligados aos recursos computacionais para processamento e armazenamento dos dados.

A formação de rede de empresas possibilita algumas vantagens (RIBAULT et al., 1985): i) cada uma das empresas pode aprofundar uma especialização; ii) as empresas de uma rede podem tornar-se o reflexo da atividade econômica dessa rede; iii) as empresas podem escolher a rede por afinidade, assim, podem constituir uma rede exclusiva ou original em relação às empresas concorrentes.

Wasserman e Faust (1994, p.4) destacam que: i) através das redes os atores e suas ações são vistos como interdependentes e cada ator é uma unidade autônoma; ii) as ligações ou as relações entre atores são canais para transferir ou fluir recursos, sejam materiais ou imateriais; iii) modelos de rede provêm oportunidade para restrição sobre ações individuais. As regularidades ou padrão de ligações entre os atores são denominadas de estruturas, sendo que, as ligações podem ser de qualquer tipo de relacionamento entre os atores: transações comerciais, fluxos de recursos, fluxos de informações e conhecimentos. Com relação a esses últimos, será dedicada maior atenção e detalhamento dos tipos e fluxos de conhecimento em redes de empresas no tópico 2.21 deste capítulo.

A literatura tem produzido uma expressiva lista de motivos pelas quais as organizações ingressam em redes. Dentre as várias razões apontadas, a formação das redes de empresas pode ser motivada pelos seguintes fatores (OLIVER, 1990): i) por imposição legal ou por determinação de uma instância superior, como no caso de certas linhas de financiamento, às quais é permitido acesso somente a 
consórcios entre empresas e instituições de pesquisa; ii) por controle ou assimetria, quando uma organização procura exercer poder sobre outra ou por pretender controlar os seus recursos; iii) por reciprocidade, quando relações são estabelecidas por organizações que compartilham objetivos comuns, iniciando relações de cooperação e coordenação; iv) por necessidade de maior eficiência interna, quando uma organização, preocupada em melhorar sua eficiência, estabelece relações com outras para reduzir seus custos de transação; $v$ ) por estabilidade, quando organizações buscam o estabelecimento de relações com outras empresas para diminuir sua vulnerabilidade das incertezas do ambiente competitivo; vi) por legitimidade, quando uma organização pretende melhorar sua reputação e/ou imagem através do estabelecimento de relações com organizações aceitas e respeitadas em seu meio.

Dentre os motivos apresentados também podem ser incluídas as "redes de conhecimento", que são constituídas quando o objetivo é aprender e/ou adquirir conhecimentos e competências (LEI e SLOCUM, 1992).

\subsection{Origem e Conceitos de Redes}

O termo rede não é novo e tem vários enfoques com diversos significados e aplicações nos mais diferentes contextos. Originalmente, o termo vindo do latim, se reportava a uma armadilha para capturar pássaros, formada por um entrelaçamento de fios e linhas, cujos nós eram formados pelas intersecções destes fios e linhas. Mais tarde, no século XIX, o termo adquiriu sentido mais abstrato, denominando todo o conjunto de pontos com mútua comunicação (MARCON e MOINET, 2000).

Em termos genéricos, rede é um conjunto de pontos ou nós conectados entre si, que viabilizam o intercâmbio de fluxos - de bens, pessoas ou informações, entre os diversos pontos da estrutura. Alguns autores ampliaram este conceito, dado que estas conexões, pelo desenvolvimento da tecnologia de informação se ampliaram 
para uma dimensão global. Segundo Castels (1999, p. 498), a revolução da tecnologia de informação é o ponto de partida para analisar a complexidade da nova economia. Assim, na visão deste autor, "redes são estruturas abertas capazes de expandir-se de forma ilimitada, integrando novos nós desde que consigam comunicar-se dentro da rede, ou seja, desde que compartilhem os mesmos códigos de comunicação (...). Uma estrutura social com base em rede é um sistema aberto altamente dinâmico, suscetível de inovação sem ameaças ao seu equilíbrio".

Sobre as redes, Amato Neto (2000: 46) constata que "em uma primeira aproximação podem referir-se à noção de um conjunto ou uma série de células interconectadas por relações bem definidas".

No campo de estudo das Ciências Sociais, o termo designa um conjunto de pessoas ou organizações interligadas direta ou indiretamente. $\mathrm{Na}$ literatura da Economia Industrial, as redes representam uma forma organizacional de interação entre os diversos agentes (MARCON e MOINET, 2000; LASTRES e CASSIOLATO, 2004), são definidas como método organizacional de atividades econômicas através de coordenação e/ou cooperação inter-firmas (PORTER, 1998), e também são equivalentes as formas especiais de alianças estratégicas entre empresas e organizações (AMATO NETO, 2000).

A teoria de redes está diretamente relacionada com o reconhecimento da importância do ambiente organizacional e das contingências vividas e, principalmente com a importância e necessidades das pessoas e suas diversas formas de interação e integração (individual e coletiva) social para a consecução dos objetivos organizacionais e individuais (CÂNDIDO e ABREU, 2000).

Os estudos sobre as redes oferecem importante base de interesses de diversas abordagens teóricas de diferentes áreas do conhecimento, que não devem ser vistas como excludentes, mas complementares. Por exemplo, a perspectiva das redes, existentes no âmbito da Antropologia e da Psicologia Social, desde os anos 30, tem encontrado muitas aplicações em campos diversos como a Sociologia, a Política, a Medicina e mais recentemente, na Economia, introduzindo as relações 
sociais e o contexto em que os agentes (atores sociais) interagem e cooperam, tomando decisões condicionados pela rede em que estão inseridos. Estes são elementos de grande relevância na análise econômica.

Uma rede social tem a ver com o conjunto de pessoas, organizações, etc. ligado através de um conjunto de relações sociais. Nesta perspectiva, a estrutura das organizações deve ser entendida e analisada em termos de redes múltiplas de relações internas e externas. As redes organizacionais podem ser consideradas uma decorrência dos conceitos e princípios das redes sociais e podem ser divididas em intra e interorganizacionais (NOHRIA, 1992). O primeiro quando envolve aspectos internos, partindo do princípio de que as organizações podem ser vistas como uma rede de pessoas, departamento e setores mantendo uma constante rede de relações, por uma subdivisão hierárquica, vertical e horizontal. E o segundo, envolve uma estrutura, na qual as empresas mantêm relação de interdependência e interrelacionamento, através da coordenação e cooperação entre empresas.

De acordo com León (1998), as redes de empresas são formadas inicialmente, com o objetivo de reduzir incertezas e riscos, organizando atividades econômicas através da coordenação e cooperação entre empresas.

Fukuyama (2000) destaca que é necessário considerar a rede não somente como um tipo de organização formal, mas como um capital social, através de grupo de agentes individuais que têm em comum normas e valores que vão além daqueles necessários às transações habituais de mercado. Segundo este autor, o Vale do Silício, embora possa parecer um ambiente de extrema concorrência e de individualismo competitivo, demonstra, através de vários estudos, que existe uma rede informal de relacionamentos, de diversas fontes, por exemplo, antecedentes educacionais comuns, que induzem a um processo de integração. As redes intensificam a interação, promovendo uma redução do tempo e do espaço nas interrelações entre os seus atores, fatores altamente estratégicos para a competitividade das organizações (FAYARD, 2000). 
O esforço de tentar abranger todas as possibilidades existentes de redes nas suas várias tipologias, consiste uma simplificação forçada diante da ampla diversidade e falta de uniformidade de conceitos e classificações existentes. Neste trabalho serão descritas algumas classificações de redes e um mapa de orientação conceitual das dimensões sobre as quais as redes são estruturadas onde podem se enquadrar as demais tipologias existentes.

\subsection{Tipologias de redes interorganizacionais}

As redes de cooperação interorganizacionais têm sido apontadas como o novo locus da inovação, onde o conhecimento, através dos processos de aprendizado pode ser gerado de forma mais eficiente e rápida. As redes constituemse em alternativa quanto à forma de organizar a produção de bens e/ou serviços e quanto à melhora da posição competitiva das empresas (AMATO NETO, 2005).

De maneira geral, as redes possuem as seguintes formas (CÂNDIDO e ABREU, 2000):

a) bilaterais/multilaterais: quando envolvem dois ou mais elementos, respectivamente;

b) homogêneas/heterogêneas: quando existem diferenças mais ou menos acentuadas entre os componentes da rede;

c) formais/informais: quando envolvem ou não um conjunto de normas, regras e procedimentos preestabelecidos;

d) estáticas/dinâmicas: quando são mais ou menos influenciadas pelas forças ambientais, consequentemente, criando um certo grau de convivência com as mudanças.

As redes de empresas aparecem em diferentes contextos e a partir de expressões culturais diversas. Dentro o vasto universo de tipologias, os autores Grandori e Soda (1995) propõem uma tipologia bastante conhecida e utilizada na literatura de Economia de Empresas, na qual as redes são descritas e classificadas 
segundo os seus graus de formalização, centralização e mecanismos de cooperação (ver figura 2.2).

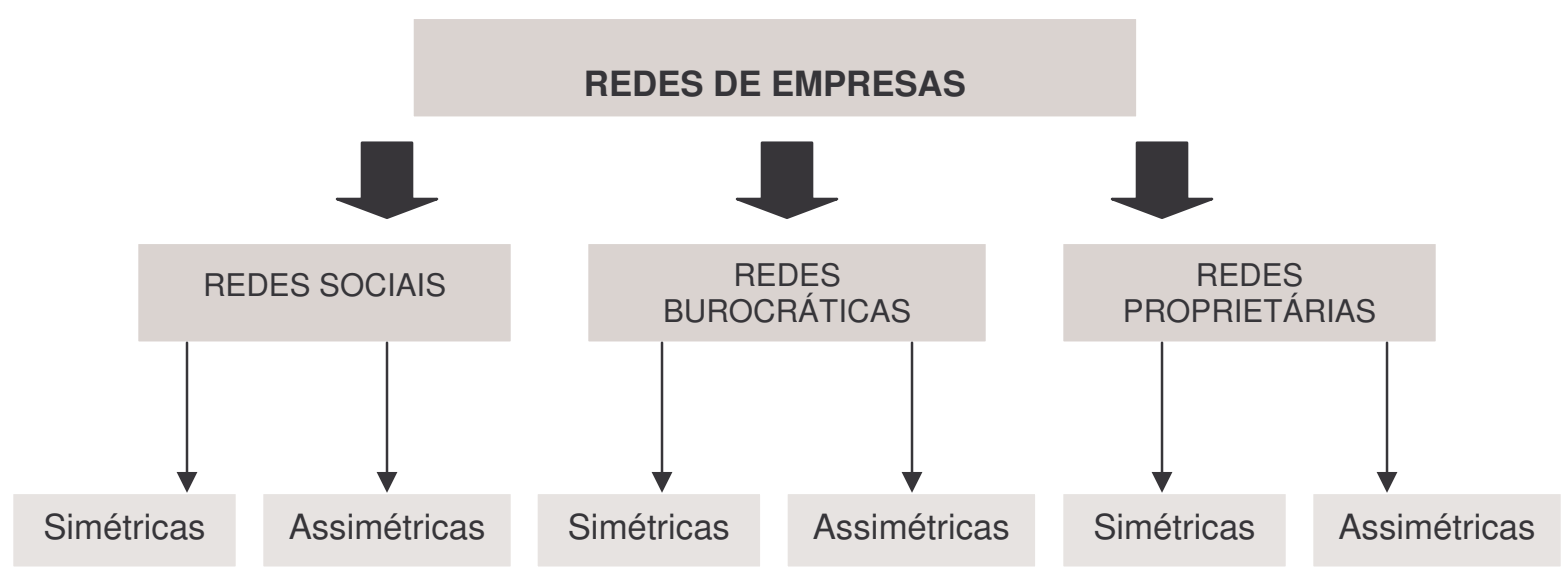

Figura 2.2 - Tipologia de Redes de Empresas

Fonte: Grandori \& Soda (1995)

Segundo este autor, as redes empresarias podem se apresentar como:

- Redes Sociais: onde o relacionamento dos que integram a rede não é regido por nenhum tipo de contrato formal. Elas podem ser subdivididas em redes sociais simétricas e redes sociais assimétricas;

- Redes Sociais Simétricas: todos os participantes da rede têm a mesma capacidade de influência, ou seja, não existe um pólo detentor de poder diferenciado. Este tipo de rede é indicado para estimular desenvolvimentos de caráter exploratório, onde as informações tratadas apresentam alto potencial, mas valor econômico desconhecido. Outra utilidade está em regular transações entre parceiros quando contribuições e desempenho são difíceis de avaliar por meios contratuais ou burocráticos. Os Pólos e Distritos Industriais são um exemplo clássico deste tipo de rede.

- Redes Sociais Assimétricas: neste tipo de rede há a presença de um agente central. Existe freqüência de contratos formais entre as firmas, do tipo, especificações do produto e serviços negociados, mas não com relação à organização do relacionamento entre as empresas. 
- Redes Burocráticas: são caracterizadas pela existência de contrato formal, com a finalidade de regular especificações de fornecimento, bem como a organização da rede e o relacionamento entre os integrantes.

- Redes Burocráticas Simétricas: são caracterizadas por acordos formais entre diversas firmas, porém sem prevalecer interesses particulares. As Associações Comerciais representam um exemplo clássico.

- Redes Burocráticas Assimétricas: são caracterizadas por acordos formais entre diversas firmas, prevalecendo interesses particulares. As franquias e as redes de licenciamento são exemplos conhecidos deste tipo de rede.

- Redes Proprietárias: caracterizam-se pela formulação de acordos formais relativos ao direito de propriedade entre os acionistas de empresas. São classificadas como simétricas e assimétricas.

- Redes Proprietárias Simétricas: são as joint ventures, geralmente empregadas na regulação das atividades de pesquisa e desenvolvimento, inovação tecnológica e sistemas de produção de alto conteúdo tecnológico.

- Redes Proprietárias Assimétricas: encontradas nas associações do tipo capital ventures que relacionam o investidor de um lado e a empresa parceira de outro. Os acordos de decisão conjunta e transferência de tecnologia são encontrados em maior freqüência.

Outra contribuição quanto às informações sobre redes é dada por Ernst (1994). Ele aponta que a maioria das atividades econômicas nos setores mais importantes é organizada em cinco tipos diferentes de redes:

i) Redes de Fornecedores: envolvem subcontratação e acordos entre clientes e fornecedores de insumos intermediários à produção;

ii) Redes de Produtores: abrange os acordos de co-produção que possibilitam que mesmo produtores concorrentes juntem suas capacidades produtivas e recursos (financeiros/humanos) para ampliarem portfólios de produtos e cobertura geográfica;

iii) Redes de Clientes: caracterizada pelos acordos e contratos entre indústria e distribuidores, canais de comercialização, revendedores com 
valor agregado e usuários finais em grandes mercados de exportação ou domésticos;

iv) Redes de Coalizões-padrão: potenciais definidores de padrões globais firmam acordos com a finalidade de prenderem tantas empresas quanto possível a seu produto proprietário ou padrões de interface;

v) Redes de Cooperação tecnológica: caracterizada por acordos que facilitem a aquisição de tecnologia e o desenvolvimento de projetos e produção de produtos que permitem acesso compartilhado a conhecimentos genéricos e pesquisa e desenvolvimento (P\&D).

\subsection{Redes Top-down e Flexíveis}

Segundo Casarotto Filho e Pires (1999) as redes de empresas podem ser agrupadas em dois tipos básicos: i) redes top-down; e ii) redes flexíveis.

As redes top-down caracterizam-se por subcontratações, parcerias, terceirizações e outras formas de repasse de produção, na qual empresas de menor porte fornecem direta ou indiretamente sua produção à uma empresa-mãe. Tanto a empresa-mãe, quanto suas dependentes competem pela liderança em custos.

As redes flexíveis de pequenas empresas caracterizam-se pela formação de consórcios de objetivos comuns, em que o conjunto de atividades das pequenas empresas juntas fazem com que estas atuem como uma grande empresa. Isto Ihes trazem vantagens competitivas baseadas em flexibilidade e custo.

Lei e Slocum (1992) caracterizam "redes de conhecimento", as redes que são constituídas quando o objetivo é aprender e/ou adquirir conhecimentos e competências.

Os autores Lipnack \& Stamps (1994) apontam algumas razões para as empresas atuarem em redes em algumas funções e práticas administrativas: 
- Marketing: para marketing conjunto, pesquisas de mercado, avaliação de necessidades comuns, marcas comuns, serviços de exportação, etc.

- Treinamento: para obter conhecimentos especializados, habilidades gerais e específicas, etc.

- Recursos: para aquisições e/ou compras conjuntas, armazenagem/estocagem conjunta, coordenação de fornecedores, equipamentos especializados, serviços profissionais, etc.

- Pesquisa e Desenvolvimento (P\&D): para desenvolvimento conjunto de produtos e/ou serviços, desenvolvimento conjunto de processos, compartilhamento de pesquisa e inovações, transferência e difusão de tecnologias, etc.

- Pesquisa: programa conjunto de qualidade, Benchmarking, compartilhamento de padrões internos, certidão de padrões internacionais, etc.

\subsection{Organizações e Empresas Virtuais}

A diferença básica das empresas virtuais para outros modelos de rede, é a freqüência e a intensidade da cooperação, ou seja, a configuração, dissolução e reconfiguração dessas redes acontecem repetidamente em um período relativamente curto (BREMER e CORREA, 2001).

Uma organização virtual pode ser entendida por intermédio de dois pontos de vista: funcional e institucional.

Do ponto de vista institucional, a organização virtual é legalmente uma combinação das melhores competências essenciais de empresas legalmente independentes que cooperam entre si de forma dinâmica para a solução de problemas, através de uma base superior da Tecnologia da Informação. Cada membro tem acesso aos recursos existentes em toda a rede e o risco de cada empreendedor é dividido entre os parceiros da rede (AMATO NETO, 2005). Do 
ponto de vista funcional concentra-se em competências essenciais (core competences), que são coordenadas de forma dinâmica e orientadas para a solução de problemas.

Goldman et al. (1995, p. 198) mencionam seis razões estratégicas que beneficiam as empresas que decidem adotar o modelo de cooperação de organização virtual:

- compartilhamento de infra-estrutura, pesquisa \& desenvolvimento, custos e riscos;

- união de competências complementares;

- redução do conceito de tempo através do uso de bens compartilhados;

- aumento das instalações e do tamanho aparente;

- acesso a mercados e partilha dos mercados ou da fidelidade do cliente; e

- venda de soluções e não de produtos.

Uma das entidades de negócio mais importantes da empresa virtual é o broker ou agenciador que deve possuir um profundo conhecimento da área em questão. Entre outras coisas, ele é o responsável por prospectar oportunidades no ambiente global e por habilitar a criação das empresas virtuais (BREMER e CORRÊA, 2001).

\subsection{Comunidades de Prática}

O conceito de Comunidade de Prática (CoP) foi cunhado pelo teórico organizacional Etienne Wenger, como sendo comunidades que reúnem pessoas informalmente por interesses comuns no aprendizado e principalmente na aplicação prática do aprendido (WENGER, 1998).

Comunidades de Prática também podem ser definidas como agrupamento de pessoas que compartilham e aprendem uns com os outros por contato físico ou virtual, com um objetivo ou necessidade de resolver problemas, trocar experiências, 
modelos padrões ou construídos, técnicas ou metodologias, tudo isso com previsão de considerar as melhores práticas (MCDERMOTT, 2000).

O objetivo de participar de uma CoP é uma necessidade autêntica de aprender com outros membros em um ambiente de aprendizado forte, que tem como base a troca de informações - de modo síncrono ou assíncrono. Os encontros podem ser regulares ou não, em locais fixos com "agendamento" prévio ou não e virtuais ou reais, porém podem reunir pessoas que jamais se encontrariam de outra forma para aprenderem juntas (TERRA, 2003).

Para que uma CoP se estabeleça, três características são fundamentais (WENGER, 1999, p.3):

i) domínio: refere-se à área de conhecimento em torno da qual se constrói a comunidade e isto se transforma em sua identidade (provê foco comum). Um domínio bem definido legitima a comunidade pela afirmação dos propósitos e valores dos membros. Os domínios não precisam ser sempre os mesmos pois eles giram em torno dos interesses da comunidade.

ii) comunidade: em busca dos interesses no seu domínio, os membros participam de atividades conjuntas e discussões, ajudam uns aos outros e compartilham informações. Assim, eles formam uma comunidade em torno do seu domínio e constroem relacionamentos. Esta comunidade sustenta-se na idéia da diversidade e complementaridade. As regras estabelecidas para seu funcionamento e escopo são fundamentais para sua longevidade, caso contrário, existe o risco de se promover longos e improdutivos debates.

iii) prática: uma comunidade de prática não é simplesmente uma comunidade de interesses ${ }^{4}$, seus membros desenvolvem um repertório compartilhado de recursos, que incluem uma variedade de tipos de conhecimento : casos e histórias, teorias, regras, frameworks, modelos, princípios, ferramentas,

\footnotetext{
${ }^{4}$ comunidade de interesses: grupo de pessoas não estão conectadas para o desenvolvimento de uma prática comum ou do compartilhamento de uma determinada área do conhecimento, mas por um interesse particular.
} 
especialistas, artigos, lições aprendidas e melhores práticas. Incluem aspectos tácitos e explícitos do conhecimento da comunidade (ancora a aprendizagem).

A combinação dos três elementos (domínio, comunidade e prática) é o que permite as Comunidades de Prática administrarem o conhecimento.

As CoP's podem ser uma estrutura bastante atraente para a promoção do conhecimento coletivo e a inovação organizacional. Entretanto, não é comum encontrar registros sobre esta prática na literatura de aglomerações produtivas, como uma estratégia para a geração de aprendizado e conhecimento local.

\subsection{Orientação Conceitual das dimensões sobre redes}

Para alcançar uma melhor compreensão da diversidade de tipologias existentes Marcon e Moinet (2000) criaram um gráfico de orientação conceitual que permite compreender as principais dimensões sobre as quais as redes são estruturadas, e enquadrar as diversas tipologias existentes (ver figura 2.3).

Nas orientações do mapa, o eixo vertical indica a natureza dos elos gerenciais estabelecidos entre os atores da rede e o eixo horizontal, o grau de formalização estabelecido na relação com os atores. Os elos podem representar uma atividade de cooperação, no caso de uma rede horizontal (como as redes de cooperação de PME's) ou grau de relação hierárquica, no caso de uma rede vertical (como uma rede do tipo matriz/filial). Podem mover-se de uma conveniência informal entre os atores (relações de afinidade, amizade, parentesco) até relações formais estabelecidas por contratos entre as partes (contratos jurídicos de joint ventures). 


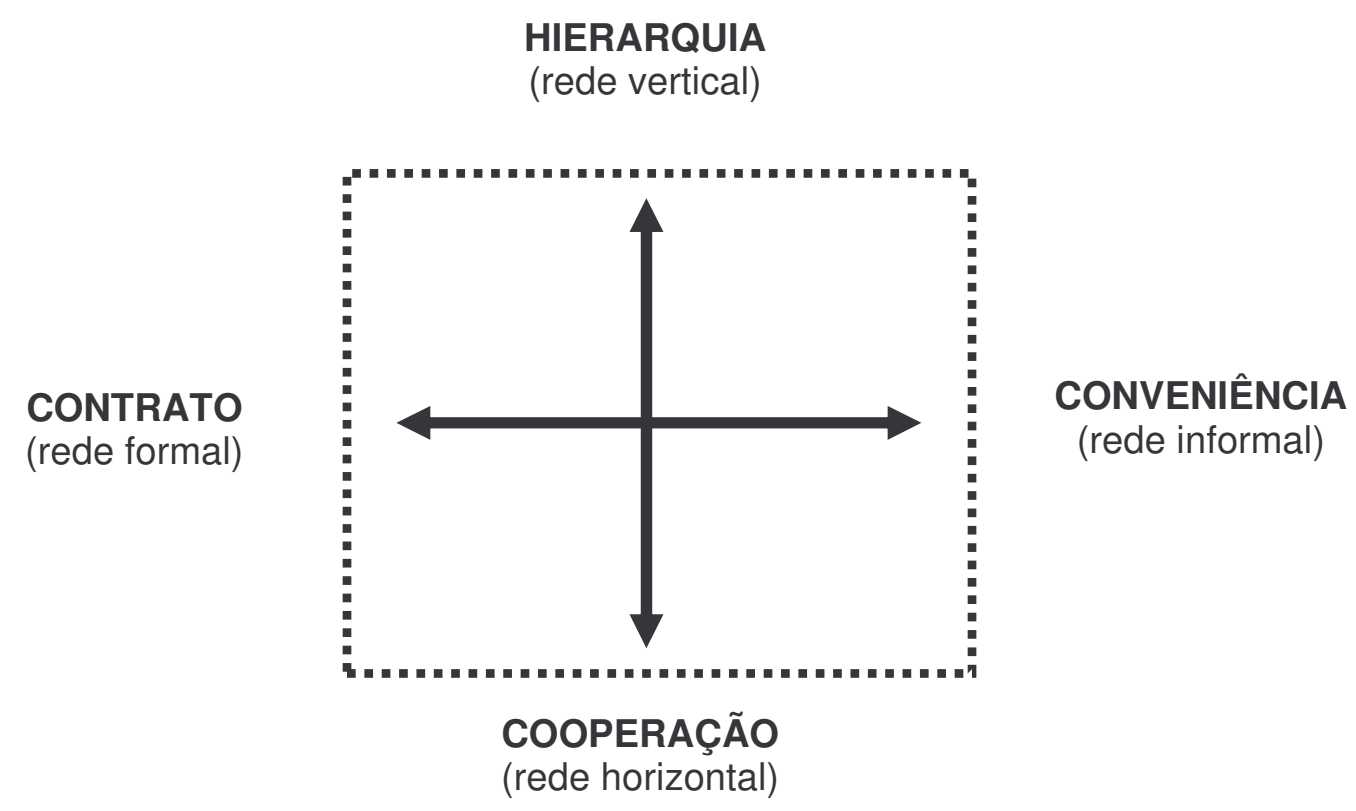

Figura 2.3 - Mapa de Orientação Conceitual

Fonte: Balestrin e Vargas (2004) baseados em Marcon e Moinet (2000)

Em cada um dos diversos pontos dos quadrantes pode ser configurado um tipo particular de rede, elucidando assim, a ampla diversidade de tipologias e caracterizações existentes na literatura. Com base nas orientações do mapa, e baseado em outros estudos sobre o assunto, as redes podem ser amplamente classificadas em 4 tipos:

- Redes Verticais - a dimensão da hierarquia: as redes verticais possuem clara estrutura hierárquica. É um tipo de configuração bastante utilizada por grandes empresas que querem estar mais próximas de seus clientes em razão da dispersão espacial (por exemplo grandes redes de distribuição, matriz/filial).

- Redes Horizontais - a dimensão da cooperação: as redes horizontais podem ser caracterizadas pelas redes de cooperação interfirmas, nas quais, as empresas coordenam de forma conjunta certas atividades específicas, porém sem perder a independência. Constituem-se baseadas na cooperação de seus membros, que escolhem a formalização flexível para melhor adaptar a natureza de suas relações. Tais redes constituem-se para criar novos mercados, obter suporte de 
custos e riscos em pesquisa e desenvolvimento de produtos, gestão da informação e de tecnologias, ações de marketing, entre outros. Há uma grande diversidade de formas deste tipo de rede, alguns exemplos são: os consórcios de compra, as associações profissionais, as redes de lobbying, e as alianças tecnológicas. Um ponto importante em termos de estratégia de rede é que as relações interfirmas formam um ambiente de aprendizagem através da cooperação.

- Redes Formais - a dimensão contratual: caracterizam-se por redes formalizadas através de regras de conduta e termos contratuais entre os atores. Exemplos deste tipo de rede fortemente formalizadas são as alianças estratégicas, consórcios de exportação, joint-ventures e franquias.

- Redes Informais - a dimensão da conveniência: caracterizam-se por redes formadas por atores econômicos diversos, com base em preocupações semelhantes, onde os encontros permitem a troca de experiências e informação baseados na livre participação. Este tipo de rede permite criar uma cultura de cooperação e de auxílio, baseada na confiança entre os atores, que pode facilitar relações mais freqüentes e estruturadas.

\subsection{Redes Interorganizacionais e suas contribuições para as Pequenas e Médias Empresas}

São cada vez maiores os desafios enfrentados pelas empresas, principalmente pequenas e médias, num ambiente cada vez mais exigente. Porém, existe um consenso entre os vários estudos sobre as PME's de que a solução para enfrentarem seus desafios de sobrevivência e competitividade passa pela formação de redes de cooperação.

Isto porque o isolamento ou individualismo torna quase impossível a essas empresas seguir o ritmo de mudanças e as exigências de atualização tecnológica e gerencial, a adaptação às tendências de mercado e os ganhos de escala necessários à competição, ao passo que a cooperação torna essas exigências 
possíveis a custos menores. A estratégia em rede representa para as pequenas empresas um meio eficaz para o desempenho competitivo, uma vez que organizadas desta forma, elas podem somar esforços para competir com as grandes empresas. As empresas podem cooperar no desenvolvimento de projetos comuns através de ações especializadas de complementaridade para a resolução de problemas e/ou necessidades comuns que vão além do seu alcance isolado (CEGLIE e DINI, 1999).

Conforme Ebers e Jarillo (1998), as redes interorganizacionais permitem às empresas alcançarem e sustentarem vantagem competitiva pelas seguintes razões: i) através do aprendizado mútuo, as empresas tornam-se capazes de suportar melhor o desenvolvimento de produtos; ii) através da coespecialidade, as firmas participantes da rede tornam-se lucrativas em novos nichos de produtos e mercados; iii) através dos fluxos de informação e da sua coordenação, as empresas reduzem as incertezas nas relações, uma das principais fontes de custos de transação; iv) como resultado de investimentos conjuntos, as empresas ganham economias de escala.

Casos mundiais de sucesso de redes de PME's, a exemplo dos distritos industriais da Emilia Romanha, na chamada Terceira Itália, tornou-se referência de como as PME's podem obter êxito e competitividade. São muitos os benefícios que podem ser usufruídos pelas PME's nestas localidades, dentre eles o acesso a informações úteis para as suas estratégias que são captados por meio de observatórios econômicos que monitoram o ambiente e informam as empresas associadas. A esse respeito, Porter (1999) argumenta que uma rede tem a capacidade de acumular uma grande quantidade de informações dos mais diversos tipos, com acesso preferencial garantido pela inter-relação de seus membros. Referências como essa tem influenciado políticas públicas, pesquisadores, pensadores, empresários e instituições a debaterem e procurarem formas de obter desenvolvimento econômico e vantagens competitivas às PMES' com base em estratégias em rede (FAGGION et al., 2002).

Existem várias tipologias de redes de PME's que poderiam estar localizadas em diversos pontos do mapa de orientação conceitual de Marcon e Moinet (2000) 
(figura 2.3 do item 2.18), a exemplo de redes verticais de subcontratação (onde PME's fornecem produtos e serviços à outras empresas), que já foram amplamente estudadas. Entretanto, este tópico, tem como objetivo tratar, em particular, as redes de cooperação, nas quais, as PME's se juntam com o objetivo de somar esforços para o alcance de determinados objetivos comuns que só podem ser alcançados por meio de ações conjuntas.

Segundo Balestrin e Vargas (2004) uma rede horizontal de PME's possui as seguintes características: i) é formada por um grupo de PME's ii) as empresas possuem proximidade geográfica iii) as PME's atuam em segmento específico de mercado; iv) as relações entre as empresas são horizontais e cooperativas, prevalecendo mútua confiança; v) a rede é formada por indeterminado período de tempo; vi) as regras de governança são básicas com mínimos instrumentos contratuais.

Já para Perrow (1992), a confiança e a cooperação são aspectos que representam papel central no sucesso alcançado pelas redes de PME's. A confiança não pode ser intencionalmente criada, mas pode ser encorajada ou gerada a partir de uma estrutura e contexto adequados. A confiança nas interrelações dos atores é um dos fatores que promove a redução dos custos de transação e torna a existência das redes economicamente viáveis (EBERS e JARILLO, 1998).

A importância da confiança é ainda maior ao se considerar as empresas que fazem uso intensivo de tecnologia e conhecimento, a exemplo da indústria de software, (STUART, 1998), onde há necessidade crescente de trocas de informações e recursos entre as empresas em virtude da instabilidade inerente a natureza desse tipo de negócio.

$\mathrm{Na}$ economia baseada no conhecimento, a criação de competências e/ou capacitações é crucial para as empresas sobreviverem e manterem-se competitivas. Nessas condições, o conhecimento é o ativo principal e o aprendizado o processo central (JOHNSON e LUNDVALL, 1994). Assim, um aspecto importante a ser considerado sobre as redes de empresas e suas contribuições às PME's é que, as 
redes podem ser concebidas como instâncias de aglutinação e criação de competências ao longo do tempo por meio de um processo coletivo de aprendizado onde o conhecimento pode ser gerado de forma mais eficiente e rápida ampliando o potencial inovativo das firmas. Vale lembrar, também, que as empresas de pequeno e médio porte, em geral, não possuem, isoladamente, condições de promoverem a (re)qualificação e capacitação de seus funcionários, fato que é possibilitado pela estrutura em rede, através de ações conjuntas com outras empresas e instituições. As ações coletivas também contribuem para a geração de incorporações de inovações tecnológicas, melhoria de processos e qualidade das empresas. Os aspectos relevantes relacionados à geração e difusão do conhecimento e aos processos de aprendizado serão apresentados nos tópicos seguintes.

Para finalizar este tópico, a tabela 2.5 apresenta as tipologias de redes de empresas, considerando os vários autores citados. 
Tabela 2.5 - Síntese das Tipologias de Redes de Empresas

\begin{tabular}{|c|c|}
\hline AUTOR & TIPOLOGIA \\
\hline Nohria (1992) & $\begin{array}{l}\text { Redes Intra-organizacionais: relações de pessoas, } \\
\text { departamentos e setores da organização. } \\
\text { Redes Interorganizacionais: interdependência e inter- } \\
\text { relacionamento entre empresas, através da coordenação e } \\
\text { cooperação. }\end{array}$ \\
\hline $\begin{array}{l}\text { Grandori e Soda } \\
\quad(1995)\end{array}$ & $\begin{array}{l}\text { Redes Sociais: Simétricas e Assimétricas } \\
\text { Redes Burocráticas: Simétricas e Assimétricas } \\
\text { Redes Proprietárias: Simétricas e Assimétricas }\end{array}$ \\
\hline Ernst (1994) & $\begin{array}{l}\text { Redes de Fornecedores: subcontratação e acordos entre } \\
\text { clientes e fornecedores de insumos intermediários à } \\
\text { produção } \\
\text { Redes de Produtores: acordos de co-produção entre } \\
\text { produtores } \\
\text { Redes de Clientes: acordos/contratos entre indústria e } \\
\text { distribuidores, canais de comercialização, revendedores com } \\
\text { valor agregado e usuários finais. } \\
\text { Redes de Coalizão-padrão: players globais firmam acordos } \\
\text { com empresas para determinarem padrões. } \\
\text { Redes de Cooperação Tecnológica: acordos para } \\
\text { aquisição de tecnologia e desenvolvimento de projetos e } \\
\text { produção de produtos, acesso compartilhado a } \\
\text { conhecimentos genéricos e pesquisa e desenvolvimento } \\
\text { (P\&D). }\end{array}$ \\
\hline $\begin{array}{l}\text { Casarotto e Pires } \\
\text { (1999) }\end{array}$ & $\begin{array}{l}\text { Redes Top-Down: Subcontratação, terceirização, parcerias } \\
\text { Redes Flexíveis: Consórcios }\end{array}$ \\
\hline Ribault et al. (1999) & Alianças Estratégicas: joint-ventures \\
\hline $\begin{array}{l}\text { Bremer e Corrêa } \\
\quad(2001)\end{array}$ & $\begin{array}{l}\text { Organização virtual: Visão Institucional e Funcional } \\
\text { Institucional: combinação das melhores competências } \\
\text { essenciais de empresas legalmente independentes. } \\
\text { Funcional: Concentração em competências essenciais } \\
\text { coordenadas através de uma base de tecnologia de } \\
\text { informação. }\end{array}$ \\
\hline $\begin{array}{l}\text { Marcon e Moinet } \\
\quad(2000)\end{array}$ & $\begin{array}{l}\text { Redes verticais: hierarquia } \\
\text { Redes horizontais: cooperação } \\
\text { Redes Formais: contrato. } \\
\text { Redes Informais: conveniência }\end{array}$ \\
\hline Wenger (1998) & $\begin{array}{l}\text { Comunidades de Prática: troca e geração de } \\
\text { conhecimento e aprendizado }\end{array}$ \\
\hline
\end{tabular}

Fonte: Autora 


\subsection{A natureza do Conhecimento}

Este tópico tem como objetivo abordar algumas questões relativas ao conhecimento, que auxiliarão na análise e discussão dos conceitos que serão apresentados posteriormente, tais como o conhecimento organizacional e suas dimensões.

Na literatura recente, o conhecimento está, cada vez mais, sendo considerado como um recurso crítico das firmas, dada a sua capacidade de gerar inovações (JOHNSON e LUNDVALL, 2000; NONAKA e TAKEUCHI, 1995, 1997; TEECE, 1998; AMIN e COHENDET, 2004). Desta forma, as vantagens competitivas das firmas estão cada vez mais dependentes da forma como criam, estocam, reproduzem, difundem e assimilam o conhecimento em diferentes situações.

Para compreender melhor a dinâmica do conhecimento é necessário defini-lo, caracterizá-lo e distingui-lo de outros conceitos como, dado e informação que, por vezes, confundem-se e são empregados de forma indiferenciada e com significados idênticos ou semelhantes.

Os dados são definidos como um conjunto de fatos discretos e objetivos sobre eventos ou "observações do estado do mundo". No universo das firmas, os dados são freqüentemente descritos como registros estruturados de transações (DAVENPORT e PRUSAK, 1998). Bellinger (2002) refere-se aos dados como pontos sem sentido no tempo e espaço, sem referência ao contexto que os originou. Eles são importantes para as firmas, caracterizam-se como matéria-prima da informação, mas uma coleção de dados também não é ainda informação. A atribuição de sentido aos dados, a sua relação com um contexto e a sua interpretação é que transformam esses dados em informação. Assim, a informação pode ser entendida como a compreensão das relações entre dados, ou entre dados e outra informação, sendo, essencialmente, descritiva. Quando existe um padrão de relações entre dados e informação, esse padrão tem potencial para representar conhecimento. 
Segundo Koch (1998), o conhecimento é associativo, inclui reflexão e síntese, permitindo associar diferentes estados com as suas representações mentais, que são descritas através da informação. Pode ser também definido como uma mistura fluída de experiências, valores, informação contextual e insights que dá origem a uma estrutura para a avaliação e incorporação de novas experiências e informações. Tem origem e é aplicado na mente das pessoas.

Nas organizações, o conhecimento está freqüentemente enraizado nos documentos e repositórios, bem como nas rotinas, processos, práticas e normas. Desta definição ressalta-se a complexidade do conhecimento, dada a sua origem na mente das pessoas e, por elas aplicado, e também o caráter dicotômico do conhecimento, estando tacitamente nas pessoas, bem como explicitamente em produtos e procedimentos formais. Assim, o conhecimento é "uma mistura fluida de experiência condensada, valores, informação contextual e insight experimentado, a qual proporciona uma estrutura para avaliação e incorporação de novas experiências e informações" (DAVENPORT E PRUSAK, 1998:5-6). Por fim, tanto a informação quanto o conhecimento são específicos ao contexto e estão relacionados na medida em que dependem da situação e são criados de forma dinâmica a partir da interação social (NELSON e WINTER, 1982).

Von Hayek (1945) foi um dos autores pioneiros a conceituar o conhecimento por meio da proposição de diferentes formas ou dimensões de conhecimento em diversas circunstâncias ${ }^{5}$. O autor critica os modelos econômicos clássicos, os quais assumem que o conhecimento consiste num bem público e que por isso não é exclusivo e todos os agentes econômicos podem ter conhecimento de tudo. Ele assume que as vantagens competitivas individuais encontram-se na disponibilidade e uso da informação original e que, portanto, o acesso específico e escasso ao conhecimento, o torna poderoso e valioso para quem o tem.

\footnotetext{
${ }^{5}$ Para uma explicação mais pormenorizada sobre o assunto, ver Von Hayek (1945) The use of knowledge in society. The American Economic Review, vol.35, issue,4 September, p.519-530.
} 
Anos posteriores, Nonaka e Takeuchi (1997) também evidenciaram que o conhecimento das organizações, em sua essência, era a sua fonte de vantagem competitiva.

\subsection{Dimensões do Conhecimento}

Polanyi (1967) foi o primeiro autor a distinguir claramente a dimensão epistemológica do conhecimento, introduzindo os conceitos de conhecimento tácito (subjetivo) e conhecimento explícito (objetivo). O primeiro pode ser entendido como aquele conhecimento que é difícil de articular, de ser tocado, codificado, pois é pessoal e dependente do contexto no qual está inserido. Está enraizado à experiência de cada indivíduo e às habilidades desenvolvidas através da experiência prática. Pode estar incorporado em hábitos ou regras de comportamento. Está associado ao conhecimento do "expert" na solução de problemas, ou ainda à intuição que permite a tomada de algumas decisões sem motivo explicável ou aparente. Propaga-se na relação existente entre as pessoas, como encontros e conversas, desde que elas disponibilizem esforços para torná-lo acessível à outros. Já o segundo, pode ser parcialmente expresso em linguagem formal e sistemática ou números. Sua construção não depende da participação direta do indivíduo, pode ser codificado e transformado em formato viável de ser utilizado por pessoas ou organizações (DAVENPORT e PRUSAK, 1998; NONAKA e TAKEUCHI, 1995; 1997; HOPE e HOPE, 2000; TERRA, 2000).

"A transferência do conhecimento tácito implica na necessidade do contato face a face e por conseqüência na proximidade espacial entre os agentes e na importância dos códigos de compartilhamento, fazendo com que o contexto social seja decisivo para as possibilidades de transferência. Essa percepção reforçou a importância dos estudos recentes sobre aglomerados industriais. Novos estudos também têm sugerido que "a habilidade dos trabalhadores ou das firmas para produzir e compartilhar conhecimento tácito depende da proximidade espacial ou afinidades culturais". (GERTLER, 2001, p.15). Em particular depende do capital social e da proximidade institucional, isto é, o compartilhamento de normas, 
concessões, valores, expectativas e rotinas que nascem da experiência comum emoldurada pelas instituições ${ }^{6}$.

Nonaka e Takeuchi $(1995,1997)$ importante referência na atualidade sobre o conhecimento organizacional e suas dimensões, ampliaram o entendimento a respeito do assunto, no sentido de pensar o mecanismo de criação do conhecimento como um processo holístico de convergência entre as formas de conhecimento tácito e codificado.

Os autores sugerem quatro modos de conversão de conhecimento, chamado de processo SECI (socialização, externalização, combinação e internalização): socialização (conversão de conhecimento tácito em conhecimento tácito, baseado no compartilhamento de experiências, modelos mentais ou habilidades técnicas compartilhadas através da imitação, observação e prática); externalização (conversão de conhecimento tácito em conhecimento explícito, expresso na forma de conceitos, linguagem escrita, hipóteses ou modelos criado pelo diálogo ou pela reflexão coletiva); combinação (conversão de conhecimento explícito em conhecimento explícito, baseado na combinação de conjuntos diferentes de informações e conhecimento explícito para que haja a criação de novos conhecimentos). Educação formal e treinamento podem ser exemplos do processo de combinação; e internalização (conversão de conhecimento explícito em conhecimento tácito - é o processo de incorporação do conhecimento explícito no conhecimento tácito, mas também absorção de tácito de fora). Nesta última fase, pode ocorrer o learning by doing, ou seja, a aprendizagem por experimentação.

\footnotetext{
${ }^{6}$ As instituições constituem-se em um conjunto de hábitos comuns, rotinas, práticas, regras e leis que regulam as interações e relações entre indivíduos e grupos. Elas podem trazer vantagens concorrenciais entre os produtores, principalmente no caso destes produtores pertencerem a um determinado cluster. Podem ser divididas em duas categorias: instituições formais, como as leis trabalhistas, leis de patentes, direitos de propriedade e regulamentações governamentais definidas geralmente no âmbito nacional, revelando aspectos das políticas macroeconômica e industrial; instituições informais, como os elementos próprios da sociedade - costumes, confiança, disposição à cooperação, tradições, regras sociais, práticas e normas de conduta - as quais, dependendo da sua força, podem levar à uma intensa identificação sociocultural entre os agentes locais, estimulando a interação entre eles. Nelson e Winter (1982), Nadvi (1995) e Schmitz (1997).
} 
Segundo os autores, conhecimento tácito e explícito são interdependentes e/ou complementares e é na interação de ambos (formando uma espiral de conhecimento) que surge a inovação.

Uma organização que promove a criação e o compartilhamento do conhecimento tácito e explícito, pode ter melhores condições para atuar de forma mais dinâmica e estratégica em seus negócios (HOPE e HOPE, 2000).

Outra dimensão do conhecimento, é a chamada dimensão ontológica, que refere-se ao locus do conhecimento, que pode residir no nível individual ou coletivo.

No âmbito das organizações, o conhecimento individual é aquele que está na mente e nas habilidades conceituais e cognitivas de cada pessoa. O conhecimento explícito neste nível relaciona-se, por exemplo, à educação formal e ao treinamento. E no nível tácito está relacionado à intuição, aos valores e modelos mentais do indivíduo. Já o conhecimento coletivo ou organizacional é aquele estocado em regras, procedimentos, rotinas e normas que orientam as atividades de solução de problemas e os padrões de interação entre seus membros. Este tipo de conhecimento está relacionado aos caminhos pelos quais o conhecimento é distribuído e compartilhado entre os membros da organização. O conhecimento explícito neste nível está codificado e estocado em planos, projetos, fórmulas, regras e procedimentos na forma de best practices e manuais. Por fim, o conhecimento tácito no nível oganizacional reside nas rotinas e normas organizacionais compartilhadas, como exemplo, tradições, modelos de recompensa e punições, entre outros (LAM, 2000).

A potencialidade das redes interorganizacionais em gerar novos conhecimentos foi evidenciada por Nonaka e Takeuchi (1997) ao desenvolverem sua própria dimensão ontológica de crescimento organizacional baseada em níveis de entidades criadoras de conhecimento. Nesta dimensão, o conhecimento nasce em um nível individual, sendo ampliado pela dinâmica da interação ou socialização do conhecimento para um nível organizacional e, posteriormente, para um nível interorganizacional 
Segundo os autores, a espiral de conhecimento surge a partir da interação do conhecimento tácito e explícito, elevando-se dinamicamente de um nível ontológico inferior até níveis mais altos. Observa-se que o conhecimento gerado no âmbito das redes é considerado um nível mais completo, abrangente e expressivo da criação do conhecimento, pois tem seu processo de criação iniciado no nível individual, que através da interação de conhecimentos explícitos e tácitos atinge e transforma-se em conhecimento interorganizacional (figura 2.4). Assim, pode-se dizer que uma rede interorganizacional pode proporcionar um ambiente favorável à existência de uma efetiva interação entre pessoas, grupos e organizações, ampliando interorganizacionalmente o conhecimento criado pelos indivíduos (FAGGION et al., 2002). Essa dinâmica forma uma comunidade de conhecimento, onde o conhecimento, as práticas, os valores, os processos, a cultura e as diferenças são compartilhados coletivamente em favor de um projeto comum.

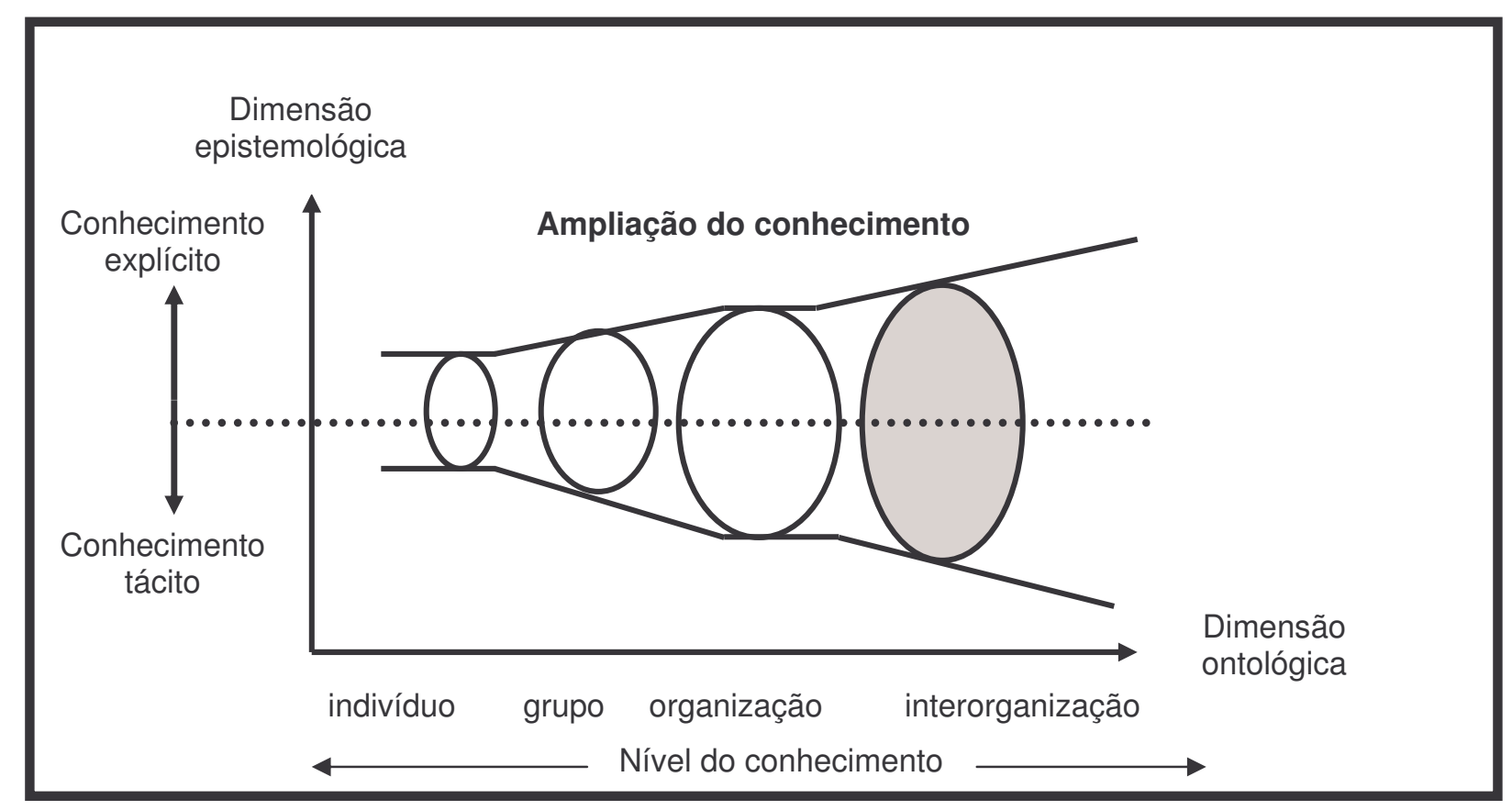

Figura 2.4 - Espiral de criação do conhecimento Fonte: Nonaka e Takeuchi (1997)

De modo geral, a formação de redes, em seus diversos níveis e aplicações, tem sido considerada, tanto na prática quanto na teoria, um mecanismo capaz de potencializar o compartilhamento de informação entre organizações e indivíduos e 
de contribuir para a geração de conhecimento e inovação tecnológica (AUSTIN, 2001). Para Corno et al. (1999) as redes representam o lugar onde os processos de aprendizado e de sedimentação do conhecimento tomam forma.

Mesmo quando se busca reciprocidade entre as firmas, o conhecimento pode perder sua transparência (tornando-se "viscoso") sob determinadas condições, e transferir-se com dificuldade ou mesmo deixar de ser transmitido, frustrando assim uma das intenções da rede (NAKANO, 2005).

Segundo Nonaka e Teece (2001), o conhecimento só é transferido quando o ator que o recebe tem a capacidade de absorvê-lo, caso contrário, o processo de transferência foi incompleto.

Três eixos e fatores de influência podem ser utilizados na análise do processo de transferência (ou difusão) do conhecimento nas redes interorganizacionais, conforme a tabela 2.6, a seguir (NAKANO, 2005). Tais fatores podem facilitar ou não o fluxo de conhecimento entre as firmas.

Tabela 2.6 - Eixos e fatores para transmissão do conhecimento

\begin{tabular}{|c|c|c|}
\hline Dimensão & $\begin{array}{c}\text { Palavra- } \\
\text { chave }\end{array}$ & Fator de influência \\
\hline simples x complexo & Volume & volume de informações a ser transferido \\
\hline $\begin{array}{c}\text { independente } x \\
\text { sistêmico }\end{array}$ & Pacote & $\begin{array}{c}\text { transmissão de um conhecimento isolado ou } \\
\text { de um pacote de conhecimentos }\end{array}$ \\
\hline tácito x explícito & Canal & vetor (veículo portador) do conhecimento \\
\hline
\end{tabular}

Fonte: Nakano (2005, p. 58)

O autor explica que, com relação ao volume quanto mais simples e independente o conhecimento for, mais fácil será a sua transmissão. Assim, conhecimentos de menor complexidade (ou independentes) são mais fáceis de serem transmitidos do que aqueles mais complexos, e conhecimentos independentes se transmitem de forma mais ágil do que aqueles mais abrangentes (conhecimentos sistêmicos que exigem a posse de outros conhecimentos ou do contexto da organização transmissora, para ser totalmente compreendido) 
(NAKANO, 2005, p. 57-58). Com relação à terceira dimensão, enquanto o conhecimento explícito exige canais que tenham capacidade de transmitir palavras e símbolos, o conhecimento tácito, por sua vez, exige canais que possibilitem interação. Via de regra, a transmissão de conhecimento é mais ampla se exigir canais de comunicação com menor capacidade.

Ainda outros dois fatores de influência podem inibir ou facilitar o fluxo de comunicação entre as firmas (NAKANO, 2005):

i) fatores relacionados à organização: quanto maior a estrutura de relacionamento das firmas, maior são seus recursos de rede (mais contatos, mais possibilidades de obter informações, de localizar necessidades de outros e divulgar as próprias e maior potencial para o estabelecimento de redes e parcerias). Outro aspecto relacionado diz respeito à forma como os relacionamentos entre as firmas estão estabelecidos. Se as relações são diretas, ou seja, se o contato é direto com as organizações que interage, as firmas podem compartilhar com maior facilidade recursos. Já as relações indiretas (dependente de intermediários) podem permitir fluxos de informações mais lentos e imprecisos, alongando o canal de comunicação e aumentando a possibilidade da introdução de ruídos;

ii) capacidade administrativa: a firma deve permanecer em constante atividade de cooperação para manter sua capacidade administrativa para trabalhar em rede. Isto envolve assuntos como a definição de autoridade para a tomada de decisão dentro da rede, estabelecimento de limites de cooperação, das responsabilidades e direitos legais, normas e procedimentos internos para lidar com parceiros.

Cabe destacar que para esta pesquisa, o nível interorganizacional refere-se aos fluxos de informação e conhecimento no âmbito de redes locais de conhecimento de PME's. 


\subsection{As dimensões dos processos de aprendizagem}

A capacidade de construir novas competências pode ser considerada fator principal para a obtenção de vantagens competitivas das firmas. A rápida e continua mudança técnica provoca a formação e destruição do estoque de conhecimento especializado, exigindo continua capacidade de aprendizado (LUNDVALL et al., 2001). A construção e reconstrução das habilidades organizacionais e tecnológicas estão relacionadas a estruturação dos seus processos de aprendizagem.

A aprendizagem pode ser vista como a capacidade de integrar diferentes tipos de conhecimentos numa atividade industrial. Assim, a geração e a difusão de conhecimento tácito e codificado, tem lugar em firmas e organizações através de atividades de aprendizagem (ARROW, 1962:156).

Jonhson e Lundvall (2000:16) definem a aprendizagem como sendo a aquisição de diferentes tipos de conhecimento, competências e habilidades, que são responsáveis por um indivíduo ou uma organização obter mais sucesso no alcance de seus objetivos.

Os processos de transferência de conhecimento e aprendizado para as PME's são fundamentais não só na sua necessidade de aumentar competitividade, mas também em acumular conhecimento e ganhar competências desenvolvendo eficiência organizacional melhorando o uso dessas competências (TEECE e PISANO, 1994; DOGSON, 1996).

A crescente importância do conhecimento para os processos competitivos tem estimulado os estudos sobre capacitações das empresas e tem destacado diferentes dimensões dos processos de aprendizagem, dentre elas, as fontes de conhecimento internas e externas.

Entre os processos gerados a partir de fontes internas à firma, estão: a experiência de produção e suas consequentes inovações incrementais em produtos e processos, que criam capacidades inovativas internas às firmas, através do 
chamado learning by doing e learning by using (LUNDVALL, 1995) e as atividades formais de pesquisa e desenvolvimento, ou de departamentos de engenharia e marketing, denominadas por Malerba (1992) de learning by searching.

Entretanto, uma das atividades críticas para o processo inovativo é a utilização de fontes externas de conhecimento. Conforme Lundvall (1995), a capacidade de inovar está fortemente condicionada ao conhecimento gerado fora da empresa, o qual é captado através de processos de aprendizagem (learning by interaction) que ocorrem nas relações entre firmas (concorrentes ou não), clientes e fornecedores, e entre estas e outros tipos de organizações, tais como, institutos de pesquisa, universidades e poder público. Este último, por exemplo, quando ocorre a promoção indireta de desenvolvimento tecnológico através de políticas públicas, como: regulamentações, programas empresariais e de incentivo e fomento. As fontes externas como o sistema de ciência e tecnologia e, outras firmas, podem se combinar com as fontes internas de conhecimento.

A captação de conhecimento externo também pode ocorrer através da mobilidade de capital humano e de processos de imitação mencionados na literatura como spillovers.

Nos processos de imitação, as firmas se observam mutuamente, interceptam informações que circulam no APL (spillovers de conhecimento), e estudam os produtos, processos e estratégias das suas concorrentes. No caso da mobilidade de mão-de-obra, as formas mais comuns de captação de conhecimento são feiras, eventos, congressos, seminários, visitas técnicas, treinamentos conjuntos, rotatividade de pessoal, serviços de consultoria. Essas atividades permitem 0 acesso a novos conhecimentos até então não disponíveis às firmas ou indivíduos.

A distinção entre fontes internas e externas de conhecimentos apropriados no processo de aprendizado é útil como base para a descrição de fenômenos que ocorrem no interior das redes de firmas.

Johnson e Lundvall (1992) formularam algumas hipóteses básicas a respeito do contexto no qual ocorre o processo de aprendizado por interação: i) o 
aprendizado interativo envolve um "processo social", a partir do qual se desenvolvem conceitos básicos de linguagem entre os agentes; ii) quanto mais complexo for o aprendizado, maior será a interação requerida para viabilizá-la, uma vez que a compatibilização de padrões cognitivos e a transmissão de conhecimentos tácitos será mais complicada; iii) para que a interação se aprofunde é necessário que haja contínuo aperfeiçoamento dos códigos e canais de comunicação entre os agentes, os quais atuam como infra-estrutura facilitadora do intercâmbio de informações; iv) a continuidade da interação introduz a possibilidade de novas combinações para diferentes tipos de conhecimento.

Todo conhecimento gerado e acumulado através dos vários processos de aprendizagem constitui o cerne da capacidade de inovação das empresas. $\mathrm{Na}$ perspectiva schumpeteriana, a inovação, concebida como um processo permanente de "destruição criativa" (SCHUMPETER, 1984), pode se manifestar de duas formas distintas: as radicais e incrementais.

As radicais surgem via-de-regra, como o resultado de grandes inversões em pesquisa e desenvolvimento (P\&D) nas grandes corporações ou em instituições de pesquisa científica e tecnológica, envolvendo fatores externos ao ambiente produtivo. Já as inovações incrementais envolvem pequenas alterações nos produtos, processos e organização da produção idealizadas e implementadas por, pessoas envolvidas diretamente no processo produtivo (IGLIORI, 2001). Não importa o tipo de inovação (radical ou incremental), o que se quer destacar é que a aprendizagem e o conhecimento são a "medula" da capacidade de inovação das firmas.

\subsection{Considerações Finais do Capítulo}

Primeiramente, neste capítulo, foram apresentadas as teorias e diferentes abordagens existentes na literatura que contribuem para dar maior entendimento às eficiências coletivas das empresas localizadas em aglomerações produtivas locais. 
Tais vantagens são derivadas de externalidades espontâneas, mas especialmente através da intensificação de vínculos inter-organizacionais por meio da cooperação. O aproveitamento das sinergias coletivas decorrentes desses vínculos efetivamente fortalece as chances de sobrevivência e crescimento, particularmente das PME's.

Outro destaque dado no capítulo foi para as diferentes configurações em rede de empresas que possibilitam que o conhecimento seja gerado de forma mais eficiente e rápida através dos fluxos de conhecimento e processos de aprendizado entre as empresas. Assume-se que a presença de instituições públicas ou privadas que prestam serviços de apoio e de qualificação dos recursos locais colaboram para a ocorrência de processos de aprendizagem e inovação nas empresas.

As relações inter-firmas também estão inseridas no contexto institucional e influenciadas fortemente pelo capital social local, o qual determina uma trajetória singular de acesso e compartilhamento de conhecimento.

A geração e a difusão de conhecimento nos APL's pode ser pensada como um circuito que propaga conhecimento tácito e codificado alimentando uma rede de novos conhecimentos. Considerando as dificuldades das PME's para obtenção de conhecimento e realização de $P \& D$, nas mais diversas áreas, faz com que participar de uma rede, por meio de processos de interação, traga-lhes a oportunidade de monitorar novas tecnologias e obter conhecimentos necessários para viabilização de inovações. Dentre várias opções, as ações coletivas contribuem para a geração de incorporações de inovações tecnológicas e melhoria de processos e qualidade das empresas.

A importância das redes é ainda maior ao se considerar as empresas que fazem uso intensivo de tecnologia e conhecimento, a exemplo da indústria de software, onde há necessidade crescente de trocas de informações e recursos entre as empresas em virtude da instabilidade inerente a natureza desse tipo de negócio.

Diante das diversas tipologias de redes de empresas que foram apresentadas, vale mencionar que esta tese se deterá em investigar as fontes externas de geração de conhecimento e os processos de aprendizado mais comuns às redes de PME's 
do setor de software que serão melhor explicitadas no capítulo de Metodologia desta tese.

O grande desafio durante a elaboração do referencial teórico foi precisamente a integração de vários conceitos, como aglomerações produtivas, redes de empresas, pequenas e médias empresas, geração de conhecimento e processos de aprendizado, de modo que respondesse à finalidade da pesquisa e que ajudasse a construir a base teórica e conceitual da mesma.

Por esta razão, a tabela 2.7 apresenta uma síntese do capítulo com os principais autores e conceitos deste capítulo que compõem o referencial teórico da tese.

\begin{tabular}{|c|c|}
\hline Conceitos & Autores \\
\hline $\begin{array}{l}\text { Aglomerações Produtivas, Distritos Industriais, } \\
\text { Clusters, Arranjos e Sistemas Produtivos Locais:, são } \\
\text { caracterizados de maneira abrangente pela concentração } \\
\text { geográfica de empresas, sobretudo MPME's, de um mesmo } \\
\text { setor que apresentam como ponto comum os ganhos de } \\
\text { eficiência coletiva que podem ser alcançados através da } \\
\text { combinação de economias externas não planejadas e } \\
\text { economias obtidas por ações conjuntas deliberadas. }\end{array}$ & $\begin{array}{c}\text { Schmitz (1997, 1999); } \\
\text { Krugman (1991); Porter } \\
\text { (1988, 1993, 1999); } \\
\text { Humphrey (2003); Marshal } \\
\text { (1920); Storper (1996, } \\
\text { 1997); Becattini (1979, } \\
\text { 1989, 1990, 1998); Scott } \\
\text { (1998); Brusco (1990); } \\
\text { Brusco et al. (1996); } \\
\text { Markusen (1995); Rabelotti } \\
\text { (1995); Viesti (2000); Nadvi } \\
\text { e Schmitz (1999): } \\
\text { Cassiolato e Szapiro } \\
\text { (2002); Amato Neto (2000); } \\
\text { Brito (2002); Sengenberger } \\
\text { e Pyke (1992); Sousa } \\
\text { (2005); Meyer-Stamer } \\
\text { (2001); European } \\
\text { Commission (20020; } \\
\text { Bollinger et al. (1983); } \\
\text { Andriani et al. (2005); } \\
\text { Lastres e Cassiolato } \\
\text { (2004); Lemos (2003); } \\
\text { Gereffi (1998); Florian } \\
\text { (2005); Vargas (2002); } \\
\text { Machado (2003); Suzigan } \\
\text { et al. (2003) }\end{array}$ \\
\hline $\begin{array}{l}\text { Eficiência Coletiva: vantagens competitivas estáticas e } \\
\text { dinâmicas derivadas de externalidades locais e ações } \\
\text { conjuntas. } \\
\text { Externalidades locais: benefícios ou eficiências não } \\
\text { planejadas ou incidentais decorrentes de fatores existentes }\end{array}$ & $\begin{array}{l}\text { Schmitz (1997, 1999); } \\
\text { Krugman (1991); Porter } \\
\text { (1988, 1993, 1999); } \\
\text { Humphrey (2003); Marshal } \\
\text { (1920); Storper (1996, } \\
\text { 1997); Becattini (1979, }\end{array}$ \\
\hline
\end{tabular}


em uma região com concentração de empresas do mesmo setor (mão-de-obra especializada, fornecedores e transbordamentos de conhecimento e tecnologia entre firmas.

Ações conjuntas: ações conscientes e planejadas de atores locais que compõem uma concentração geográfica de empresas de um mesmo setor.
1989, 1990, 1998); Scott

(1998); Brusco (1990);

Brusco et al. (1996);

Markusen (1995); Rabelotti (1995); Viesti (2000); Nadvi e Schmitz (1999):

Cassiolato e Szapiro (2002); Amato Neto (2000); Brito (2002); Sengenberger e Pyke (1992); Sousa (2005); Meyer-Stamer (2001); European Commission (20020; Bollinger et al. (1983); Andriani et al. (2005); Lastres e Cassiolato (2004); Lemos (2003); Gereffi (1998); Florian (2005); Vargas (2002); Machado (2003); Suzigan et al. (2003)

Custos de Transação: custos de desenhar e monitorar contratos, ou seja, são os pontos de análise da firma vista como um conjunto de contratos. Além de buscar a maximização de lucros, as firmas necessitam minimizar seus custos de transação. Isso implica em diminuir os riscos e incertezas que caracterizam um processo de transação partindo para uma estrutura de coordenação que estabeleça um conjunto de regras que governem determinadas transações entre os agentes da rede.

Governança: modo de coordenação das redes ou atividades interdependentes. As possibilidades de desenvolvimento local são dependentes das formas de governança do sistema. A governança local pública pode ser coordenada pelo governo local para a assistência e promoção dos produtores aglomerados (centros de treinamento de mão-de-obra, centros de prestação de serviços tecnológicos, agências governamentais de desenvolvimento. Na governança local privada destaca-se o papel das associações de classe e de agências locais privadas de desenvolvimento como catalisadores do processo de desenvolvimento local através de ações de fomento à competitividade e de promoção do conjunto das empresas. A governança local privada também pode se dar por meio da coordenação de uma ou mais empresas líderes. A provisão de agentes de coordenação é crucial para superar a desconfiança e trazer maior credibilidade nas relações entre os agentes de uma rede.

Cooperação: é a ação através da qual, diferentes partes de forma consciente e planejada envolvem-se em um processo interativo para construtivamente explorar diferenças e oportunidades que podem trazer ganhos conjuntos.
North (1990); Willianson, (1985) (2000); Suzigan et al. (2003)

Gray e Wood (1991); Leon Olave e Amato Neto

(2005); Leon Olave (2003);; Humphrey e Schmitz (1998); Schmitz (1999); Rabelotti (1995)
Humphrey e Schmitz 
Políticas Públicas: as políticas públicas de apoio à
cooperação das PME's devem ser organizadas para
atender os interesses coletivos das firmas e acumular
melhorias competitivas.

Redes Interorganizacionais: forma organizacional de atividades econômicas através de interação entre diversos agentes através de coordenação e/ou cooperação interfirmas. Podem ser verticais, ao longo da cadeia, ou horizontais, entre empresas concorrentes ou não do mesmo setor. Também podem ser caracterizadas como formais, através de regras de conduta e termos contratuais entre atores ou informais, baseadas na confiança e na livre participação.

Conhecimento tácito: conhecimento pessoal e dependente do contexto no qual está inserido. Enraizado à experiência, à intuição e às habilidades desenvolvidas através da experiência prática. Propaga-se na relação existente entre as pessoas desde que elas disponibilizem esforços para torná-lo acessível à outros através de valores e códigos de compartilhamento que dependem da proximidade espacial e da experiência comum emoldurada pelas práticas, hábitos e regras que regulam as interações e relações entre os produtores.

Conhecimento explícito: conhecimento que não depende em sua construção da participação direta do indivíduo. Pode ser codificado e transformado em formato viável de ser utilizado por pessoas ou organizações

Conhecimento interorganizacional: conhecimento gerado no âmbito das redes e considerado um nível mais completo, abrangente e expressivo da criação do conhecimento, pois tem seu processo de criação iniciado no nível individual, que através da interação de conhecimentos explícitos e tácitos atinge e transforma-se em conhecimento interorganizacional. Tem demonstrado ser um mecanismo capaz de potencializar o compartilhamento de informação entre organizações e indivíduos e de contribuir para a geração de conhecimento e inovação tecnológica.

Aprendizagem: pode ser vista como a aquisição de diferentes tipos de conhecimento, competências e habilidades que são responsáveis por um indivíduo ou uma organização obter mais sucesso no alcance de seus objetivos. Os processos de aprendizado para as PME's são fundamentais não só na sua necessidade de aumentar competitividade, mas também em acumular conhecimento e ganhar competências desenvolvendo eficiência organizacional melhorando o uso dessas competências.

Processos de aprendizado a partir de fontes internas à firma: experiência de produção e suas conseqüentes inovações incrementais em produtos e processos, que criam capacidades inovativas internas às firmas, através do chamado learning by doing e learning by using e as atividades formais de pesquisa e desenvolvimento, ou de departamentos de engenharia e marketing, denominadas learning by searching.
European Commission (2004); Lastres et al. (2003); Humphrey e

Schmitz (1998); Casarotto Filho e Pires (2001)

Nohria (1992; Grandori e Soda (1995); Ernst (1994); Casarotto e Pires (1999); Bremer e Correa (2001); Marcon e Moinet (2000); Wenger (1998)

Johnson e Lundvall (2000); Nonaka e Takeuchi (1995, 1997); Teece (1998); Amin e Cohendet (2004); Davenport e Prusak (1998); Bellinger (2002); Koch (1998); Nelson e Winter ( 1982); Von Hayek (1945); Polanyi (1967); Hope e Hope (2000); Terra (2000); Gertler, 2001); Lam (2000); Faggion er al. (2002); Corno et al. (1999); Nakano (2005); Nonaka e Teece (2001);

Lundvall et al. (2001); Arrow (1962); Johnson e Lundvall (2000, 1992); Teece e Pisano (1994); Dogson (1996); Lundvall (1995); Schumpeter ( 1984); Igliori (2001). 
Processos de aprendizado a partir de fontes externas à

firma: a capacidade de inovar está fortemente condicionada ao conhecimento gerado fora da empresa, o qual é captado através de processos de learning by interaction que ocorre nas relações entre firmas (concorrentes ou não), clientes e fornecedores, e entre estas e outros tipos de organizações. A captação de conhecimento externo também pode ocorrer através da mobilidade de capital humano e de processos de imitação denominados na literatura de spillovers.

Tabela 2.7 - Síntese do Referencial Teórico

Fonte: Autora 


\title{
3 CONSIDERAÇÕES SOBRE A INDÚSTRIA DE SOFTWARE E SEU CONTEXTO
}

\begin{abstract}
Este capítulo tem como finalidade descrever as principais características da indústria de software e seu contexto e como esta se apresenta no universo da Tecnologia de Informação (TI). É também dado enfoque à natureza dos sistemas de software e aos modelos de gestão de processos e de melhoria da qualidade de software.
\end{abstract}

\subsection{Introdução}

É de conhecimento da comunidade cientifica e acadêmica de que uma pesquisa deve justificar-se dentre outros motivos, pelo seu caráter viável, relevante e oportuno. Neste sentido, pode-se afirmar que não faltam argumentos para destacar essas características com relação ao software e a relevância que o setor representa na dinâmica das economias modernas e, especificamente para o Brasil na atual conjuntura.

Dentre vários elementos que podem justificar a importância de se falar na atividade produtiva do software é de que esta indústria encontra-se no centro do atual processo de transformação tecno-econômica que é identificado por vários autores como sendo a construção de uma nova economia ou de uma economia baseada e/ou construída no conhecimento e na informação.

Isto se explica porque nas últimas décadas, os padrões de crescimento econômico mundial passaram a ser determinados por novos fatores e causas. $O$ desenvolvimento dos países passa a ser especialmente vinculado a contribuição das novas tecnologias e o modo como essas interagem com as mudanças nos campos da inovação, do capital humano e das reestruturações industriais. 
A introdução dessas mudanças tem alterado as características da forma de competir em praticamente todos os setores produtivos, onde a capacidade de mudança e inovação em tempo recorde é condição sine qua non de subsistência, tanto para países, quanto para empresas ou organizações (TAKAHASHI, 2000).

Ao mesmo tempo, os avanços nas Tecnologias de Informação (TI) tornaram possível a difusão e o acesso de informações em velocidade e escala sem precedentes, tornando vital o encadeamento da indústria com a ciência para os dinamismos locais, regionais e nacionais da estrutura de produção.

Assim, nos universos da TI, a atividade de software apresenta-se como uma atividade de importância estratégica para o desenvolvimento da competitividade de organizações e países. Portanto, o investimento e fortalecimento desta atividade como ativo de inovação é de profunda relevância.

Uma característica bastante presente da TI, sobretudo no plano internacional é a tendência dessa atividade se concentrar geograficamente em pólos, a exemplo do Vale do Silício nos EUA, Dublin na Irlanda, Bangalore na Índia e outros. Nesses polis as atividades desenvolvem-se amparadas na existência de instituições locais fortes e na ligação com as demais atividades de alta tecnologia, notadamente o software (DIEGUES, JR.,2004).

A atividade de desenvolvimento de software, ou a indústria de software como parte integrante das Tecnologias de Informação e Comunicação, apresenta participação crescente dentre estas. Afora o seu caráter de extraordinário crescimento, o software penetra virtualmente um grande conjunto de atividades econômicas, sendo em muitos casos, um elo determinante da competitividade, produtividade e da eficiência dessas atividades. Este caráter pervasivo e/ou transversal do software lhe confere ainda mais importância, na medida em que sua onipresença nas mais diversas atividades ou cadeias produtivas é fator relevante ou crucial para diversos setores da economia (ROSELINO, 2003). 
Um outro elemento intrínseco ao software dentro do paradigma da TI é que este possui as características básicas necessárias para a implementação de sistemas baseados na microeletrônica, e por outro lado é uma tecnologia descorporificada ou intangível, mas que tem seu valor determinado pelo quão efetivas são as operações computacionais realizadas, assim como pela qualidade confiável de seus resultados alcançados. Desta maneira, pode-se dizer que o software proporciona a personificação do conhecimento em produtos e/ou sistemas, o que o transforma em um ativo estratégico (FREIRE, 2002).

A indústria de software apresenta um nível de inovatividade superior a média das demais indústrias e representa um papel fundamental no desenvolvimento do aprendizado e das capacitações intra e inter-firmas, gerando importantes efeitos indutores de produtividade sobre a base industrial e de serviços.

O software tem sido utilizado como recurso estratégico de muitos países como alternativa viável para o aumento da base de conhecimentos e de capacitações produtivas (GUIMARÃES, 2005), ganhando relevância na medida em que as indústrias relacionadas às tecnologias de informação expandem sua presença na economia, bem como suas articulações com outros setores. Esse papel crucial do software o faz objeto privilegiado de políticas públicas de fomento em diversos países.

As atividades relacionadas à tecnologia de informação têm um importante papel não apenas no desenvolvimento econômico de uma determinada região fortalecendo as empresas inovadoras, mas também no desenvolvimento social, através da geração de novos postos de trabalho e renda e suporte tecnológico à difusão de informação na sociedade (SOUSA, 2004).

Dada a relevância do software como ativo estratégico, o setor tem sido alvo prioritário da Política Industrial, Tecnológica e de Comércio Exterior do Brasil em produtos, processos e serviços em software, inclusive através do fomento aos arranjos produtivos locais. Mais adiante esse assunto será tratado mais detalhadamente. 
Entretanto, apesar destas características, os elementos determinantes do desenvolvimento e sua dinâmica são ainda deficientemente compreendidos, bem como os contornos desta atividade, o que justifica o seu melhor conhecimento.

\subsection{Características e configurações gerais da atividade e/ou "indústria de software"}

A atividade de desenvolvimento de software, ou a "indústria de software"7 é parte integrante do universo das tecnologias de informação e caracteriza-se por velocidade intensa de inovações técnicas, particularmente pelo contínuo desenvolvimento de produtos através de matéria-prima bastante peculiar, 0 conhecimento, gerado e apoiado na capacidade criativa e intelectual da mão-deobra.

Devido essas características, o termo "indústria de software" deve ser entendido a partir de uma ampliação do conceito tradicional de indústria transformadora de matéria-prima para produção de mercadorias. Embora seu produto seja constituído por uma sequência de linhas de programação, as quais são denominadas "programas de computador" ou "software", não apresenta nada de tangível, embora possa ter algum suporte material (FREIRE, 2002).

Pode-se dizer que o software é antes de tudo um não-objeto uma não-coisa, que pelas suas características e propriedades apresenta soluções às necessidades humanas de diferentes naturezas, sendo estas, individual ou coletiva. Como bens finais de consumo ou, indiretamente, como "meio de produção". É também um importante insumo tecnológico de papel crescente no desenvolvimento das forças produtivas capitalistas (ROSELINO, 2006).

\footnotetext{
${ }^{7}$ Há discussão na literatura se é apropriado classificar a produção de software como uma indústria. Além das dificuldades de mensuração decorrentes da natureza imaterial e intangível do software, a própria definição dos contornos da indústria é tarefa particularmente problemática. A transversalidade do software nas diversas cadeias produtivas faz com que estas atividades estejam dispersas pelos mais diversos setores econômicos. As dimensões daquilo que se pode denominar como conjunto de atividades de software é bastante superior àquilo que se denomina indústria de software (ROSELINO, 2006).
} 
Assim, pode-se dizer quanto à natureza do software, que este proporciona a materialização do conhecimento em produtos e/ou sistemas produtivos, o que o transforma em ativo estratégico nas mais diferentes atividades econômicas das tecnologias de informação e comunicação, confundindo-se com estas no movimento de convergência tecnológica em curso (exemplo das atividades voltadas á indústria de telecomunicações e multimídia) o que dificulta definir precisamente os limites e contornos desta atividade ou "indústria".

Por esta razão, parece ser pertinente compreender o software como elo de diversas cadeias produtivas, e não como uma cadeia produtiva particular. Sua onipresença nas mais diferentes atividades econômicas é crescentemente um fator determinante na produtividade e competitividade em diversos setores da economia. O reconhecimento destas características permite tratar o papel dessa indústria com uma abordagem diferenciada que reforce a pertinência de políticas públicas de fomento à esta atividade que na medida de seus resultados transborda os imprecisos contornos de desenvolvimento das atividades de software (ROSELINO, 2003).

Uma característica de destaque dentro da atividade de software é a velocidade com que as inovações são introduzidas e transformadas em novos produtos, assim como também se tornam obsoletas rapidamente nesta indústria de intenso dinamismo tecnológico. Desta forma, qualquer análise da dinâmica competitiva desta indústria necessita levar em conta 0 papel relevante desempenhado pela introdução e difusão de inovações.

A dinâmica organizacional é outra característica presente nesta atividade econômica. As empresas necessitam monitorar constantemente o desenvolvimento tecnológico, criando produtos e estabelecendo novos mercados e para isso precisam obter agilidade e capacidade para identificar e adequar-se a essas oportunidades. Essas características determinam uma forte dependência das empresas em relação ao seu capital humano (criativo e intelectual) - ativo que acumula as capacitações tecnológicas e organizacionais (RIBEIRO, 1998). 
O dinamismo do setor de software caracteriza-se também por um conjunto de empresas jovens e heterogêneas que participam de estruturas de mercado diferenciadas que levam a comportamentos e estratégias de desenvolvimento de software também diversificadas conforme a área de atuação. Deste modo, os fatores de competitividade não apresentam o mesmo peso em todos os segmentos da indústria de software, o que resulta na necessidade de se observar o segmento em que o software é aplicado na análise de tais fatores. Por esta razão o setor carece de análises mais apropriadas devido ao seu particular dinamismo e segmentação.

Com relação à vantagem competitiva no mercado de software, esta depende prioritariamente da criação e renovação das vantagens competitivas, em um processo onde cada produtor se esforça por obter peculiaridades que o distingam favoravelmente dos demais, como por exemplo, custo e/ou preço mais baixo, melhor qualidade, menor lead-time, maior habilidade de servir à clientela, etc. (COUTINHO e FERRAZ, 1995). Tais vantagens precisam ser desenvolvidas e acumuladas nas empresas num processo que requer tempo e podem ser obtidas internamente ou proporcionadas pelo ambiente institucional no qual a empresa se insere.

A estrutura da indústria apresenta segmentos concentrados ao lado de segmentos fragmentados, com a presença de grandes corporações com produtos padronizados e escala de produção estabelecida mundialmente (Microsoft, Oracle, IBM e outras) que atuam explorando as vantagens proporcionadas pelas economias de escala, rede de vendas e suporte, reconhecimento de marca, uso de marketing, capacidade tecnológica, poder financeiro, relações fortes com usuários, etc. Ao mesmo tempo em que é crescente os espaços de nichos ocupados por um elevado número de micro, pequenas e médias empresas que atuam através de atendimento especializado de clientes, desenvolvimento de produtos que incorporam funções específicas e ocupação de outros espaços deixados pelas empresas líderes, cujas linhas de produtos não atendem a todas as necessidades (PONDÉ, 1993).

O surgimento das micro e pequenas empresas pode ser justificado pelas barreiras a entrada de grandes empresas nesses mercados, determinadas pelo tamanho do mercado, fatores geográficos, fronteiras, costumes, língua e outras especificidades nacionais, regionais e locais. 
Embora haja espaços de atuação interessantes às pequenas e micro empresas, a dinâmica da indústria é dada por grandes empresas líderes em segmentos concentrados de mercado que determinam o padrão técnico a ser seguido pelas demais empresas.

Quanto ao regime tecnológico desta indústria, há amplas condições de oportunidade e grande variedade de soluções e enfoques potenciais, porém reduzidas condições de apropriabilidade, que são contornadas pela introdução contínua de inovações por parte das empresas, utilizando-se para tanto, de elevadas condições de cumulatividade tecnológica, que ocorre tanto na firma produtora através do aprimoramento constante de seus produtos, como também nos usuários que, devido aos custos de aprendizagem incorridos, têm dificuldades em migrar para novos produtos (NICOLAU et al, 2001).

Por isso, os desenvolvimentos presentes dependem do que foi aprendido anteriormente, ou seja: "o fato essencial da indústria de software é que a mesma produz novos produtos e serviços que sempre podem ser atualizados, incrementados ou expandidos sobre uma determinada base de conhecimentos, que, por sua vez, se expande em função do conhecimento já acumulado. Assim, a criação de novos softwares, dada sua complexidade tecnológica, exige que se conheçam os fundamentos técnicos e científicos que regem esta complexidade. Uma vez compreendidos estes fundamentos, pode-se, a partir deles, criar novos produtos e ou serviços, num contínuo processo de acumulação de conhecimentos, que leva sempre ao desenvolvimento de softwares tecnologicamente superiores. Nesse sentido, quanto maior o estoque de conhecimentos da firma produtora de software, tanto maior será sua capacidade de inovar" (RAUEN, 2006:31).

As características do regime tecnológico e a dinâmica competitiva permitem que diferentes tamanhos de empresas explorem oportunidades em diferentes mercados, ou seja, há uma situação de relativa volatilidade das estruturas de mercado em determinados segmentos, assim como a existência de permanentes espaços para novos entrantes (ROSELINO, 2006). As aglomerações territoriais, a exemplo dos clusters, apresenta-se como uma possibilidade às pequenas empresas, 
onde, a princípio, parece haver condições para cumulatividade tecnológica no interior do próprio cluster.

\subsection{Tipologias das atividades de software}

A definição e classificação dos tipos de software auxiliam não apenas na compreensão da divisão de trabalho existente no interior da própria indústria, mas no entendimento da dinâmica tecnológica da indústria como um todo, servindo de subsídio instrumental às análises de competitividade do setor em segmentos diversificados.

Na consulta à literatura, percebeu-se a não existência de uma classificação internacional padronizada para as atividades de software. Entende-se que isto se dá em virtude do caráter heterogêneo das atividades desenvolvidas no interior da indústria possibilitando a existência de várias tipologias e combinações distintas, por vezes, resultando em complexas taxonomias.

Dentre as várias classificações existentes, encontram-se algumas segmentações que ajudam a compreender melhor o setor. Baseado em alguns autores, (DUARTE, 2003; KUBOTA, 2006; ROSELINO, 2006; RAUEN, 2006), podese classificar o software das seguintes formas: (i) quanto à plataforma de hardware; (ii); quanto à posição hierárquica na programação (iii) quanto ao mercado de destino; (iv) quanto à chegada ao mercado:

Quanto à plataforma de hardware, a diferenciação do software pode estar em diferentes padrões, tais como, IBM-PC, Apple-Macintosh, Mainframes, HandHeld, entre outros.

Quanto à hierarquia do software na programação, têm-se: o software básico, que é o sistema operacional que "conversa" com o computador e está na base da hierarquia; os softwares de suporte ou ferramenta que auxiliam no 
desenvolvimento de outros softwares; e o software aplicativo, destinado à solução de problemas do usuário final.

Quanto ao mercado de destino, o software pode ser dividido em duas grandes categorias: horizontal e vertical.

O segmento horizontal é caracterizado por conteúdos geralmente provenientes da área de informática, com pouco conteúdo específico de outra área de conhecimento. É flexível, vendido em forma de pacotes e tem como objetivo a resolução de problemas informacionais universais. São exemplos deste segmento, os sistemas operacionais, as planilhas, os banco de dados, processadores de texto, navegadores para a internet.

No segmento vertical, os programas são desenvolvidos para uma determinada atividade econômica e/ou nichos específicos (saúde, educação, pesquisa, bancos, bibliotecas, etc), ou, e principalmente, sob encomenda. Diferentemente do segmento horizontal, neste caso, além da informática é necessário a incorporação de outros conhecimentos específicos das diferentes áreas de atuação, fazendo com que o ciclo de vida do produto seja mais longo.

Quanto à chegada ao mercado, são quatro as formas de apresentação do software:

Software pacote: vendido em prateleiras a inúmeros clientes (demanda genérica), exige grande volume de investimentos em canais de distribuição. É geralmente padronizado e é caracterizado por não haver interação direta entre o usuário e o produtor de software durante o desenvolvimento do produto. A sobrevivência do produto é, portanto, de forma independente. A competitividade leva em conta a capacidade de desenvolvimento técnico e distribuição em massa com altos dispêndios na criação do produto. Empresas líderes investem fortemente em estratégias agressivas de marketing, aproveitando vantagens de economias de escala, rede de vendas, suporte abrangente e marca reconhecida. Portanto, este é um mercado claramente dominado por grandes corporações internacionais. Exemplos: Sistema operacional Windows e Processador de texto Word. 
Software embarcado: tem como característica básica ser incorporado e/ou embutido em um equipamento de hardware específico. A atividade de desenvolvimento deste tipo de software é uma das mais importantes e dinâmicas, uma vez que na atualidade todo equipamento automatizado, nas mais diversas áreas, traz consigo um software, ainda que de modo simples para operacionalizá-lo. Portanto, passou a ser crescente o número de funções executadas por programas de software embarcados. Exemplos: aparelhos celulares, automóveis, calculadoras, etc.

Produto Customizável: basicamente são softwares pacote que possuem uma plataforma comum de programação que permite adaptações conforme a demanda do cliente.

Software serviço (ou por encomenda): constitui-se em programas desenvolvidos sob encomendas diretas, ou seja, estruturados junto aos clientes. Isso faz com que o processo de learning by interaction seja fundamental na determinação do alcance dos objetivos determinados. Além de conhecimentos técnicos relacionados ao desenvolvimento de software, também são necessários conhecimentos específicos às áreas demandantes. Dentro desta classificação, alguns autores (SALATTI, 2005 ; ROSELINO 2006) propõem uma distinção dos serviços de software por valor agregado no seu desenvolvimento. Deste modo, têmse os serviços de baixo valor agregado e os serviços de alto valor agregado. Os serviços de baixo valor agregado são menos densos em conteúdo tecnológico; consistem em execução e rotinas simples que dependem de conhecimentos mais básicos e menos específicos; demandam apenas o domínio de conhecimentos codificáveis que podem ser obtidos com formação técnica em programação. Essas atividades são intensivas em mão-de-obra de média qualificação e apresentam pequenas possibilidades de ganhos de escala. Em contrapartida, os serviços de alto valor agregado são aqueles que envolvem etapas mais complexas do desenvolvimento de uma solução em software, ou seja, etapas hierarquicamente superiores nas funções desempenhadas pela indústria de software e representam tarefas mais complexas do processo de produção envolvendo um nível de e capacitação e qualificação mais alto da mão-de-obra utilizada. Pode incorporar ações que vão desde a análise de requisitos do cliente até o conhecimentos de 
regras do negócio (softwares sob encomenda). Reputação e confiança são requisitos fundamentais.

Para este trabalho, a tipologia adotada para referência ao estudo de campo é quanto à chegada ao mercado, por parecer mais adequada aos objetivos desta pesquisa.

Com base nesta tipologia, a tabela 3.1 apresenta uma comparação de alguns tipos de software existentes selecionados segundo alguns fatores de análise, tais como: custo marginal, mercado, interação com clientes, processos de trabalho, barreiras à entrada, aprendizado, pesquisa e desenvolvimento, mão-de-obra e exemplos de produtos.

Tabela 3.1 - Comparação dos tipos de softwares de algumas categorias selecionadas

\begin{tabular}{|c|c|c|c|c|c|}
\hline \multirow[b]{3}{*}{$\begin{array}{l}\text { Custo } \\
\text { Marginal }\end{array}$} & \multicolumn{2}{|c|}{ Serviços } & \multicolumn{3}{|c|}{ Produtos } \\
\hline & $\begin{array}{l}\text { Serviço de } \\
\text { baixo valor } \\
\text { agregado }\end{array}$ & $\begin{array}{l}\text { Serviço de alto } \\
\text { valor agregado }\end{array}$ & $\begin{array}{l}\text { Produto } \\
\text { Customizável }\end{array}$ & $\begin{array}{l}\text { Software } \\
\text { embarcado }\end{array}$ & $\begin{array}{l}\text { Software } \\
\text { pacote }\end{array}$ \\
\hline & Constante & Constante & Decrescente & Decrescente & Zero \\
\hline Mercado & Local/regional & Regional/global & Regional/global & $\begin{array}{l}\text { Global- } \\
\text { descentralizado }\end{array}$ & $\begin{array}{l}\text { Global - } \\
\text { concentrado }\end{array}$ \\
\hline $\begin{array}{l}\text { Interação } \\
\text { com clientes }\end{array}$ & $\begin{array}{l}\text { Um fornecedor } \\
\text { para um cliente }\end{array}$ & $\begin{array}{l}\text { Um fornecedor } \\
\text { para um cliente }\end{array}$ & $\begin{array}{l}\text { Um fornecedor } \\
\text { para mais de um } \\
\text { cliente }\end{array}$ & $\begin{array}{l}\text { Um fornecedor } \\
\text { para um cliente }\end{array}$ & $\begin{array}{l}\text { Um fornecedor } \\
\text { para muitos } \\
\text { clientes }\end{array}$ \\
\hline $\begin{array}{l}\text { Definição do } \\
\text { processo de } \\
\text { trabalho }\end{array}$ & $\begin{array}{l}\text { Definido pelo } \\
\text { cliente }\end{array}$ & $\begin{array}{l}\text { Em conjunto } \\
\text { com o } \\
\text { fornecedor }\end{array}$ & $\begin{array}{l}\text { Definido pelo } \\
\text { fornecedor com } \\
\text { alguma } \\
\text { participação do } \\
\text { cliente }\end{array}$ & $\begin{array}{l}\text { Definido pelo } \\
\text { fornecedor com } \\
\text { alguma } \\
\text { participação do } \\
\text { cliente }\end{array}$ & $\begin{array}{l}\text { Definido } \\
\text { apenas pelo } \\
\text { fornecedor }\end{array}$ \\
\hline $\begin{array}{l}\text { Barreiras à } \\
\text { entrada }\end{array}$ & $\begin{array}{l}\text { Grau de } \\
\text { competitividade }\end{array}$ & $\begin{array}{l}\text { Grau de } \\
\text { reputação }\end{array}$ & $\begin{array}{l}\text { Acesso à } \\
\text { tecnologia e à } \\
\text { clientes }\end{array}$ & $\begin{array}{l}\text { Acesso à } \\
\text { tecnologia e à } \\
\text { clientes }\end{array}$ & Capital \\
\hline Aprendizado & By doing & By interacting & By interacting & $\begin{array}{l}\text { By interacting/by } \\
\text { searching }\end{array}$ & By searching \\
\hline P\&D & Nulo & $\begin{array}{l}\text { Principalmente } \\
\text { desenvolvimento }\end{array}$ & $\begin{array}{l}\text { Principalmente } \\
\text { desenvolvimento }\end{array}$ & $\begin{array}{l}\text { Principalmente } \\
\text { desenvolvimento }\end{array}$ & $\begin{array}{l}\text { Principalmente } \\
\text { pesquisa }\end{array}$ \\
\hline $\begin{array}{l}\text { Mão-de-obra } \\
\text { qualificada }\end{array}$ & Baixa & Média & Elevada & Elevada & $\begin{array}{l}\text { Extremamente } \\
\text { elevada }\end{array}$ \\
\hline $\begin{array}{l}\text { Exemplos } \\
\text { de produtos }\end{array}$ & $\begin{array}{l}\text { Integração de } \\
\text { sistemas }\end{array}$ & $\begin{array}{l}\text { Atividades de } \\
\text { P\&D por } \\
\text { contrato }\end{array}$ & ERP, CRM & $\begin{array}{l}\text { Softwares } \\
\text { utilizados em } \\
\text { equipamentos } \\
\text { eletrônicos } \\
\text { diversos }\end{array}$ & $\begin{array}{l}\text { Sistemas } \\
\text { operacionais }\end{array}$ \\
\hline
\end{tabular}

Fonte: RAUEN (2006:29). 


\subsection{Breve histórico da indústria de software}

A história da indústria de software esteve desde o seu princípio vinculada à trajetória de desenvolvimento do hardware. Não havia qualquer tipo de comercialização do produto independente da máquina, ou seja, o hardware era comercializado juntamente com o software e o preço era estabelecido sobre o conjunto da solução. A venda integrada ocasionava forte dependência dos clientes aos seus fornecedores (LATEEF, 2003).

Porém, por volta de 1960, a indústria de software passa a se desenvolver de forma independente, ou seja, como unidade separada do hardware. Os custos dispendiosos de desenvolvimento que chegavam, por vezes, a superar o investimento total no hardware foram decisivos para dar início a um movimento de apropriação de um valor comercial ao software, agora separado do valor do hardware.

A IBM, em 1969, foi a primeira companhia a lançar uma unidade de software desmembrada do hardware. Desta forma, deu-se início uma nova trajetória de transformação na indústria, ganhando status de uma atividade econômica dotada de dinâmica própria marcada por diferentes estágios de desenvolvimento.

De início, a padronização das linguagens de programação e plataformas de hardware permitiram a expansão das fronteiras para além dos centros demandantes, possibilitando a internacionalização de serviços de software que até então tinha a indústria americana como destaque no mundo. Nesta fase, o software era feito principalmente sob encomenda, construído de forma personalizada, de acordo com as especificidades do sistema de computador do usuário, exigindo uma extensa variedade de experiências e habilidades (HEEKS e NICHOLSON, 2002).

A etapa seguinte caracterizou-se pelo surgimento dos pacotes de software sendo utilizados em computadores pessoais destinados ao mercado de massa ou direcionados a nichos de mercado específicos, de acordo com sua aplicação, ou ainda à demanda de serviços técnicos mais sofisticados. O surgimento e aumento 
da demanda desse tipo de software se deram pela possibilidade de redução do risco de desenvolvimento de um novo produto aliado à escassez de profissionais experientes por parte das empresas, bem como de atender ao usuário de contratar uma solução mais barata e estável se comparado à aquisição de um produto sob encomenda (SCHARE, 1995 apud SOUSA, 2004).

Numa conformação mais recente, em paralelo com o avanço das tecnologias de informação, o software se coloca como elo de ligação entre várias cadeias produtivas (ROSELINO e GOMES, 2000), sendo determinante na competitividade de um grande conjunto de atividades econômicas. Está sendo crescentemente usado em inúmeros aspectos e aplicações de negócios. Organizações estão realizando grandes investimentos em software com aplicações que vão desde a comercialização de seus produtos ao controle interno das cadeias de valores.

De início esse intenso desenvolvimento ocorreu, em grande parte, dentro de empresas de diversos segmentos da atividade econômica que buscavam na informática um meio para o aumento da produtividade. Em uma segunda fase, ocorre um forte movimento de terceirização de algumas etapas do processo de construção de software, em que os programas passam a ser desenvolvidos por empresas especializadas nessa atividade, as software-houses (RIBEIRO, 1998, SOUSA, 2004).

A trajetória tecnológica da indústria de software, até então, se comparada a outras mais tradicionais, tem mostrado sinais de amadurecimento, sobretudo com respeito à engenharia e qualidade de seus produtos, apesar de ser uma indústria ainda recente.

Neste contexto, o Brasil tem se destacado pela alta taxa de crescimento de base instalada de computadores e crescimento em software. Por isso, tem se transformado em alvo de estratégias de inúmeras empresas desenvolvedoras com atuação mundial. 


\subsection{0 contexto internacional da indústria de software}

Inicialmente, sobre a apresentação de dados da indústria internacional de software, é necessário dizer, que é preciso bastante cautela com relação às estatísticas. Conforme Roselino (2006), são muitas as dificuldades associadas à construção de estatísticas confiáveis para a mensuração dos valores comercializados em software, pelo fato de não haver uma metodologia internacional que garanta a produção de dados confiáveis deste produto/serviço, fazendo com que os números sejam, por vezes, contestados por especialistas.

Porém, é fato que a indústria de software tem sustentado nos últimos anos altas taxas de crescimento, em praticamente todos os países, nos quais está presente. Um fato importante é que desde a década de 80 , este crescimento tem sido mais dinâmico, oriundo, sobretudo, do surgimento de novas aplicações que constantemente são desenvolvidas para uma variedade de setores (HEEKS e NICHOLSON, 2002).

No ano de 1997, o mercado mundial de softwares e serviços movimentava US\$ 90 bilhões. Em 2001, a movimentação desse mercado alcançou cerca de US\$ 300 bilhões, em 2005 US\$ 700 bilhões. De acordo com o instituto americano de pesquisas e análises Gartner (ABES, 2006), que apurou os dados dos anos anteriores, estima-se para o ano de 2008 que esse valor chegue a US $\$ 900$ bilhões (gráfico 3.1).

Observa-se através dos dados que num curto espaço de tempo, a receita deste mercado multiplicou em dez vezes, o que confirma o intenso dinamismo característico da indústria de software. 


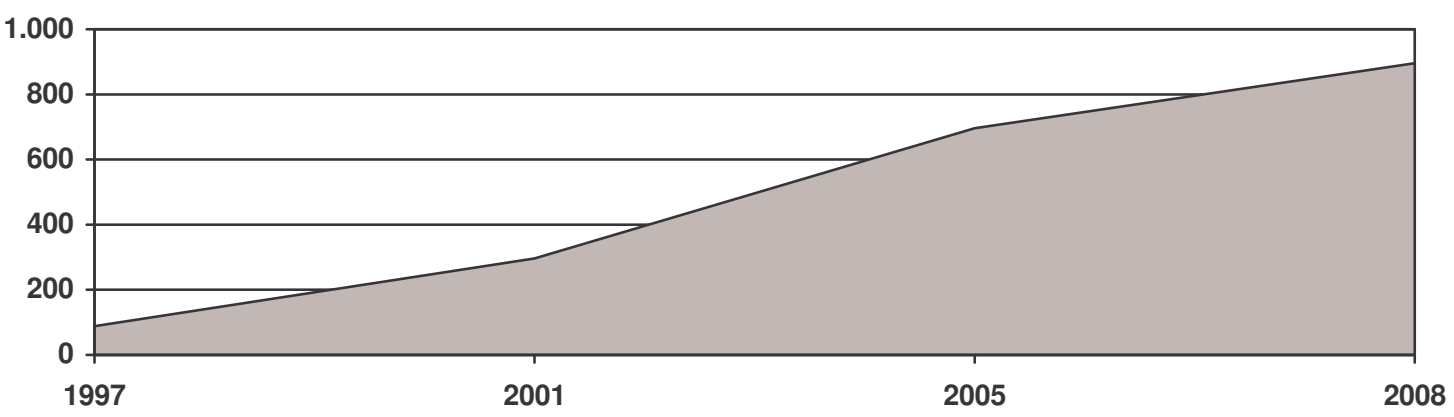

Figura 3.1 - Evolução do faturamento do mercado mundial de software 2001/2008 Fonte: (IEES), Pesquisas Gartner, 2005.

Uma característica importante dessa indústria é que algumas áreas de conhecimento se mostram extremamente concentradas (planilhas, bancos de dados e sistemas operacionais). O segmento de software pacote apresenta taxas de crescimento substancialmente maiores que o de software encomenda, embora existam diferenças entre os mercados.

O segmento de software pacote está fortemente concentrado em empresas com sede em países de economia central, e a maioria dos indicadores e previsões na literatura concorda em estabelecer uma provável convergência relativa dos vários mercados para o padrão norte-americano, no qual a prevalência de softwares pacote é maior (SOUSA, 2004).

Exemplo desta concentração de mercado é apresentado na tabela 3.2, na qual, informações da OCDE (2004) demonstram que entre as dez maiores empresas de software pacote do mundo, oito destas são americanas. O mercado de serviços também apresenta um alto grau de concentração, ainda que inferior ao mercado de software produto.

Os Estados Unidos não ocupam apenas a primeira colocação no mercado mundial, mas têm direcionado a evolução técnica e econômica da indústria internacional de software (STEFANUTO, 2004). 
Tabela 3.2 - As dez maiores empresas de software produto (valores em milhões de US\$ e número de empregados)

\begin{tabular}{|c|c|c|c|c|c|c|}
\hline Empresa & País & $\begin{array}{c}\text { Faturamento } \\
\mathbf{( 2 0 0 0 )}\end{array}$ & $\begin{array}{c}\text { Faturamento } \\
\mathbf{( 2 0 0 3 )}\end{array}$ & $\begin{array}{c}\text { P\&D } \\
\mathbf{( 2 0 0 2 )}\end{array}$ & $\begin{array}{c}\text { Empregados } \\
\mathbf{( 2 0 0 2 )}\end{array}$ & $\begin{array}{c}\text { Lucro } \\
\text { Líquido } \\
\mathbf{( 2 0 0 2 )}\end{array}$ \\
\hline Microsoft & USA & 22.965 & 32.187 & 4.307 & 50.500 & 7.829 \\
\hline Oracle & USA & 10.231 & 9.475 & 1.076 & 40.650 & 2.224 \\
\hline SAP & Alemanha & 5.747 & 9.044 & 858 & 29.374 & 533 \\
\hline Soft Bank & Japão & 3.927 & 3.449 & - & 6.865 & -708 \\
\hline $\begin{array}{c}\text { Computer } \\
\text { Associates }\end{array}$ & USA & 6.094 & 3.116 & 678 & 17.500 & -1.102 \\
\hline $\begin{array}{c}\text { Electronic } \\
\text { Arts }\end{array}$ & USA & 1.420 & 2.504 & 381 & 4.270 & 102 \\
\hline Peoplesoft & USA & 1.772 & 1.941 & 341 & 8.293 & 183 \\
\hline Intuit & USA & 1.037 & 1.651 & 204 & 6.500 & 140 \\
\hline $\begin{array}{c}\text { Veritas } \\
\text { Software }\end{array}$ & USA & 1.187 & 1.579 & 273 & 5.647 & 57 \\
\hline Amdocs & USA & 1.118 & 1.427 & 124 & 9.400 & -5 \\
\hline Total & & 55.491 & $\mathbf{6 6 . 3 7 2}$ & $\mathbf{8 . 2 4 2}$ & $\mathbf{1 7 8 . 9 9 9}$ & $\mathbf{9 . 2 5 3}$ \\
\hline
\end{tabular}

Fonte: OCDE (2004).

O alto grau de concentração desta indústria nos segmentos voltados ao software pacote, bem como, o pioneirismo e liderança da indústria norte-americana estão fundamentados desde seu princípio na vanguarda da indústria de hardware, no desenvolvimento das tecnologias de informação, associado à imposição de padrões tecnológicos dominantes, resultando em segmentos de mercado precocemente globalizados, com o predomínio das empresas desse país (ROSELINO, 2006).

"O papel da intervenção estatal foi fundamental para a consolidação da indústria de software, uma vez que "as tecnologias de software não se desenvolveram em vácuo político ou institucional, mas sim em ambientes marcados por um arcabouço institucional propício" (LANGLOIS e MOWERY apud ROSELINO, 2006). 
O mercado de software apresenta diferentes formas de internacionalização que estão associadas ao comércio/distribuição e ao desenvolvimento/produção de atividades e negócios no mercado internacional, a saber, (tabela 3.3):

Tabela 3.3 - Principais formas de internacionalização das atividades de software

\begin{tabular}{|l|l|l|l|}
\hline \multicolumn{2}{|c|}{ Comércio/distribuição } & \multicolumn{2}{c|}{ Produção/desenvolvimento } \\
\hline \multicolumn{1}{|c|}{ Atividades } & Características & \multicolumn{1}{|c|}{ Atividades } & Características \\
\hline $\begin{array}{l}\text { Venda direta de } \\
\text { produtos }\end{array}$ & $\begin{array}{l}\text { Estabelecimento de } \\
\text { rede de filiais ou } \\
\text { escritórios de } \\
\text { representação para } \\
\text { venda do produto } \\
\text { em diversas } \\
\text { localidades }\end{array}$ & $\begin{array}{l}\text { Outsourcing de fases do } \\
\text { processo produtivo }\end{array}$ & $\begin{array}{l}\text { Busca de vantagens } \\
\text { em custos de } \\
\text { atividades } \\
\text { intensivas em mão- } \\
\text { de-obra }\end{array}$ \\
\hline $\begin{array}{l}\text { Parcerias com } \\
\text { empresas locais } \\
\text { (desenvolvem } \\
\text { produtos de } \\
\text { software) }\end{array}$ & $\begin{array}{l}\text { Desenvolvimento } \\
\text { de comércio de } \\
\text { forma casada dos } \\
\text { produtos com } \\
\text { aplicativos das } \\
\text { empresas globais }\end{array}$ & $\begin{array}{l}\text { Alianças pontuais com } \\
\text { produtores } \\
\text { independentes }\end{array}$ & $\begin{array}{l}\text { Criação de soluções } \\
\text { resultando em } \\
\text { produtos integrados } \\
\text { mais completos } \\
\text { para ambas as } \\
\text { partes }\end{array}$ \\
\hline $\begin{array}{l}\text { Parcerias } \\
\text { (tecnológicas/ } \\
\text { comerciais) com } \\
\text { empresas de } \\
\text { consultoria e } \\
\text { integradoras de } \\
\text { sistemas }\end{array}$ & $\begin{array}{l}\text { Difusão do } \\
\text { software da } \\
\text { empresa global } \\
\text { (responsabilidade } \\
\text { nos serviços pré e } \\
\text { pós- venda) }\end{array}$ & Laboratórios de P\&D & $\begin{array}{l}\text { Buscar apropriação } \\
\text { de capacidades } \\
\text { existentes para o } \\
\text { desenvolvimento de } \\
\text { certas aplicações }\end{array}$ \\
\hline
\end{tabular}

Fonte: elaboração própria a partir de Roselino (2007)

Cada segmento de software possui suas especificidades. O segmento de software pacote, de uso mais geral, possui claramente uma característica global, onde as empresas líderes conquistam posições oligopolistas ou monopolistas por meio de vantagens de escala e definição de padrão tecnológico e compatibilidade que trazem fortes barreiras à entrada de novos competidores oriundos de economias periféricas ou centrais. Por sua vez, o segmento de software serviço é menos internacionalizado, ou seja, com o predomínio de empresas nacionais. É mais intensivo em trabalho, com menor rentabilidade, no qual, a proximidade e as relações de confiança entre usuário e desenvolvedor são fatores determinantes para a competitividade neste segmento (ROSELINO, 2007). 
No interior das cadeias produtivas internacionalizadas ocorre uma hierarquização das funções desempenhadas que se dá, com as seguintes características: "a grande empresa renova o acervo de recursos fundamentais para sua estratégia e posição competitiva, ao mesmo tempo em que vai externalizando as atividades secundárias. A integração vertical, dá, assim, lugar a relações mais mercantilizadas e a novas formas de cooperação. Simultaneamente, origina também a rede corporativa, uma integração crescente e hierarquizada entre as unidades produtivas que a compõem" (FURTADO, 2003:19). Assim, as empresas multinacionais dominam grande parte dos mercados e consolidam cada vez mais seus domínios, através da separação do locus da invenção (que detêm o conhecimento e tecnologias chave nas empresas lideres) do locus da produção.

Alguns países, tais como, Índia, Irlanda e Israel, dentre outros, não-centrais, como a China, Vietnã e Filipinas, têm sido os principais beneficiários dos contratos de outsourcing, especializando-se no nível mais operacional das atividades de software, ou seja, de menor intensidade tecnológica (SOUSA, 2004). Assim, as empresas dos países periféricos acabam assumindo posição passiva no processo de internacionalização, adotando padrões tecnológicos estabelecidos e absorvendo apenas parte do conhecimento e inovação gerados. O aprendizado gerado nesta forma de divisão de trabalho da indústria de software acaba sendo limitado e de caráter pouco estratégico. As estruturas produtivas voltadas ao desenvolvimento dessas funções, estão vinculadas, na condição de elos dependentes das grandes empresas globais de software dos países centrais (ROSELINO, 2006).

Segundo o SOFTEX (2004), uma parte da indústria de software no Brasil pode ser beneficiada por este tipo de contrato, pelo fato do país possuir empresas com grande experiência e capacitação em segmentos de alto nível (P\&D) e produtos corporativos verticais. Entretanto, mesmo representando uma fonte de aprendizado importante para as empresas de alguns países periféricos, o estoque de conhecimento importante, ainda que seja de uma pequena parte, é mantido sob controle da empresa líder e avaliado dentro de uma estratégia competitiva, de forma que a transferência de conhecimento realizada, não se torne uma ameaça à sua posição de mercado. 
A tendência de longo prazo na indústria de software é de que cada vez mais as assimetrias econômicas, tecnológicas e de conhecimento entre líderes e empresas seguidoras sejam aumentadas. Neste sentido é fundamental que haja um comprometimento de políticas públicas de longo prazo para a promoção da indústria em sua capacidade endógena inovativa. Tais políticas devem ir além daquelas implementadas nos anos 80 e 90, com foco em reserva de mercado (anos 80) e incentivos fiscais (anos 90). É preciso desenvolver mecanismos geradores e difusores de conhecimento e aprendizado, responsáveis pelo incremento das capacitações tecnológicas e pelo potencial inovativo das empresas e organizações (GUIMARÃES, 2005).

\subsection{O desenvolvimento da atividade de software no Brasil}

As atividades de desenvolvimento de software no Brasil têm uma história bastante recente. As suas atuais características estruturais e a sua dinâmica competitiva estão baseadas em alguns antecedentes importantes para a sua compreensão. Assim, pode-se dividir a sua evolução em basicamente dois períodos: antes de 1990, em um contexto de substituição de importações; a partir de 1990, num contexto de competição global (STEFANUTO, 2002).

Até meados da década de 70 não havia indústria de hardware nem de software no Brasil. O que ocorria era a importação do hardware como software. Entretanto, nesta época já se podia vislumbrar alguns esforços na esfera estatal, universidades e centros de pesquisa na atividade de informática do país, voltados para o desenvolvimento do minicomputador G-10 (cujo software foi desenvolvido pela PUC-RJ). Apesar de constituir-se em investimento quase irrelevante, Zukovski (1994) afirma que já existia um "mercado potencial e de capacidade técnica para o desenvolvimento de uma indústria de software" nesse período.

Para usufruir os benefícios econômicos desse mercado em potencial era necessário criar um setor que privilegiasse o desenvolvimento do software doméstico, que na sua grande parte da produção, voltada para a área administrativa, 
era realizada de forma customizada dentro das grandes usuárias de TI (DUARTE, 2003).

A partir de meados da década de 70 até o final dos anos 80, a indústria nacional no setor viveu sob o aparato de proteção de uma política de informática que tinha como objetivo a reserva de mercado para hardware, protegendo a indústria nacional (com forte controle das importações, inclusive de partes, peças e componentes) e estimulando as empresas a crescerem e inovarem através da construção de parque produtivo no país e o desenvolvimento de capacitação tecnológica na área (Nicolau et al, 2000). É nesse contexto que se cria a SEI (Secretaria Especial de Informática), órgão responsável pela então política de informática do Brasil.

Em 1975, um ato normativo No. 15/75, passa a permitir a importação de software mediante contratos de transferência tecnológica e aprovação do Instituto Nacional de Proteção Intelectual (INPI) com o objetivo de propiciar condições para o desenvolvimento de substitutos nacionais de programas difundidos no mercado internacional. Em 1987, uma política protecionista foi criada exigindo-se a inexistência de similar nacional para obter aceite registro e comercialização de software estrangeiro voltado aos equipamentos de pequeno e médio porte do país. O objetivo dessa política era de controlar as importações de software estrangeiro, mas como efeito colateral desencadeou um processo de generalização interna de cópias ilegais (ROSELINO, 2006). "Em muitos casos o software era artesanalmente reproduzido, os manuais eram fotocopiados do original em inglês e o usuário não tinha garantia quanto à qualidade do produto" (ZUKOVSKI, 1994:62).

É importante reconhecer os aspectos positivos da política protecionista e os avanços em vários campos na época, tais como, a realização de investimento em recursos físicos e humanos, espaço para crescimento e desenvolvimento de capacidades locais, de forma que no final dos anos 80 e início dos anos 90, o Brasil tinha um conjunto diversificado de empresas de capital nacional que produziram resultados significativos em $P \& D$, com presença significante no mercado local (STEFANUTO, 2002). Apesar dos produtos estrangeiros dominarem o mercado nacional, no desenvolvimento de software básico, de suporte e aplicações 
genéricas, as empresas nacionais atuavam em todos esses segmentos, algumas com relativo sucesso (DUARTE, 2003).

Entretanto, a indústria nacional foi, em grande parte, isolada do dinamismo tecnológico e comercial do mercado internacional de informática. O fechamento ao exterior implicou falta de escala, excessiva verticalização, baixo fluxo externo de tecnologia, falta de seletividade dos investimentos e dispersão dos esforços, levando ao desmonte do aparato da política de reserva de mercado e conseqüentemente à não-sustentabilidade da indústria nacional (NICOLAU et al, 2000).

Zukovski (1994) conclui em seu estudo sobre a Indústria Brasileira de Software, afirmando que a Lei de Software fracassou na tentativa de proteger as empresas nacionais da concorrência externa. Segundo o pesquisador, isso ocorreu devido à pouca eficácia "da proteção ao similar nacional" decorrente de dois fatores: i) era um processo complicado e desgastante para a empresa nacional, sobre a qual recaía o ônus da prova; e ii) a natureza do software que pressupõe um amplo potencial para diferenciação .

Quanto à esta primeira fase de evolução das atividades de software no Brasil, não há um consenso na literatura com respeito aos impactos reais da política de reserva de mercado. Enquanto alguns críticos defendem que o período foi de estagnação, outros defendem que a base tecnológica e industrial necessária para o desenvolvimento da indústria de software na fase seguinte foi estruturada no primeiro período de evolução da indústria nacional, como por exemplo, o desenvolvimento de competências locais desenvolvidas neste período (mais em software do que em hardware) e habilidades dos profissionais locais nessa área.

Com a entrada de produtos estrangeiros, as empresas locais que mantiveram a produção de software, partiram para a estratégia de exploração de nichos, desenvolvendo aplicativos específicos, ferramentas e software de suporte de mercados não atendidos pelos fornecedores estrangeiros ou ainda adaptando os próprios produtos aos produtos estrangeiros (ZUKOVSKI, 1994). 
Assim, Roselino (2006) afirma que a indústria brasileira de software constituiu-se em ambiente institucional particular, reservando espaços mais ou menos delimitados para a operação de empresas estrangeiras, nacionais, privadas e públicas, configurando um sistema complexo e heterogêneo.

No início dos anos 90, as empresas brasileiras foram forçadas a se adaptarem a um novo sistema regulatório, mais aberto e desregulamentado, dentro dos novos princípios definidos pela política industrial e de comércio do governo Collor de Melo - uma política mais orientada ao mercado. Tal sistema caracterizouse pela implantação das importações no marco da busca de uma maior integração da economia brasileira na economia internacional. Parte deste novo sistema incluía uma forte redução do papel do estado na economia, e, em 1992 a política de reserva de mercado foi plenamente abandonada.

O novo aparato regulatório dos anos 90 produziu, como resultados positivos, uma significativa queda dos custos de produção e dos markups, assim como um aumento na variedade e na qualidade dos produtos de informática no mercado brasileiro. Com tais resultados, a mudança foi bem recebida pelo contingente de usuários. Porém, em contrapartida, a abertura de mercado levou a uma reconversão industrial do setor, com um processo de desnacionalização, presença crescente de empresas estrangeiras, perdas de capacitações, desmobilizações de equipes e quedas nos investimentos em P\&D (NICOLAU et al, 2001).

É nesse contexto que se elabora a "nova lei de informática", aprovada em outubro de 1991 (Lei 8.248/91), mas que só passou a ter vigência efetiva após a regulamentação em 1993 (ROSELINO, 2006).

\subsubsection{Principais aspectos da Lei de Informática}

O principal objetivo da Lei 8.248/91 era o estabelecimento de mecanismos alternativos para a preservação da produção local e das atividades de P\&D na indústria de informática. As empresas de hardware receberiam isenções de diversos 
tipos de taxas e impostos, na medida em que comprometessem em manter certos níveis de produção local e desenvolvimento de conteúdo e P\&D, também locais (STEFANUTO, 2002).

Em outras palavras, essa legislação aboliu qualquer tratamento diferenciado com relação à origem de capital das empresas e definiu uma nova política com ênfase no estímulo fiscal ao desenvolvimento de atividades de P\&D (ROSELINO, 2006).

A Lei 8.248/91 manteve-se em vigor até o ano 2000, vindo a ser substituída pela Lei 10.176/01 (que teria vigência prevista até 2009) mantendo os principais aspectos ou o mesmo teor da lei anterior, alterando apenas alguns pontos, tais como, os percentuais dos incentivos e a definição de aplicação de parte dos mesmos a partir de critérios regionais.

"De 1993 até novembro de 2001, a Lei 8.248/91 beneficiou 428 empresas e gerou recursos para P\&D da ordem de $R \$ 2,9$ bilhões (1993/2000), sendo 63\% em pesquisa empresarial própria e 33\% em convênios com instituições de pesquisa. No mesmo período, cerca de $1 / 4$ do total dos benefícios foram aplicados no desenvolvimento de software e outros $24 \%$ no desenvolvimento de sistemas de software e hardware. Em 2000, os gastos em P\&D da indústria de TI foram de US\$ 530 milhões, dos quais 56\% resultantes de incentivo" (STEFANUTO, 2002).

Entretanto, no final de 2004, uma nova lei foi sancionada pelo governo (Lei 11.077), em substituição da Lei $10.176 / 01$. Os benefícios anteriores permaneceram sendo estendidos até o ano de 2019 e algumas alterações foram efetuadas, tais como, a diferenciação percentual do incentivo sobre o IPI (Imposto sobre Produtos Industralizados) a partir de critérios geográficos e da origem do desenvolvimento do produto (DIEGUES e ROSELINO, 2006).

Para produtos manufaturados no país, nas regiões Sul ou Sudeste, as empresas contam com uma redução de $80 \%$ no IPI; nas regiões Norte, Nordeste e Centro-Oeste, a redução aumenta para 95\%. No caso de produtos manufaturados e desenvolvidos localmente, o percentual passa a ser maior: nas regiões Sul e 
Sudeste , 95\% e para o Norte, Nordeste e Centro-Oeste, a empresa obtêm isenção total do pagamento de IPI sobre o produto fabricado. Até o ano de 2014, esses percentuais serão preservados, quando a partir de então, passarão a ser reduzidos progressivamente até serem extinguidos completamente em 2019. (SIMÕES, 2005).

Segundo Roselino (2006), a Lei de Informática como instrumento de política desempenha um papel muito importante na medida em que preserva e estimula importantes atividades tecnológicas, especialmente aquelas resultantes da atração das empresas transnacionais, no âmbito do movimento de internacionalização das suas funções produtivas. Desta forma, é permitido às subsidiárias brasileiras terem condições de competir com outros centros internacionais de desenvolvimento, uma vez que o país coloca-se como destinatário de uma parcela das atividades tecnológicas externalizadas pelas grandes empresas globais e com um importante contingente de pessoas qualificadas em esforços tecnológicos voltados ao software.

Entretanto, se por um lado pode-se considerar a Lei de Informática como um importante indutor de atividades de software no Brasil, por outro, as empresas transnacionais beneficiárias desta lei, embora desempenhem atividades tecnológicas relevantes, desenvolvendo e preservando competências locais, não estabelecem interações e ou vínculos tecnológicos relevantes (com empresas ou instituições de ensino e pesquisa) para a consolidação da indústria de software brasileira. Mesmo tendo a obrigatoriedade de realizar parte dos gastos de P\&D externamente, a empresa beneficiada acaba por estabelecer interações com instituições "semi-independentes" que preservam ligações com as empresas transnacionais beneficiárias da Lei. ${ }^{8}$

\subsection{O Software como opção estratégica na PITCE}

A Política Industrial, Tecnológica e de Comércio Exterior (PITCE), lançada em novembro de 2003, baseia-se em um conjunto articulado de medidas que visam a

\footnotetext{
8 Informações mais detalhadas a respeito dessa argumentação, ver Garcia e Roselino, (2004); Diegues Jr. (2004); Stefanuto (2004).
} 
fortalecer e expandir a base industrial brasileira por meio da melhoria da capacidade inovadora das empresas e destacou em suas diretrizes o software, juntamente com semicondutores, bens de capital, fármacos e medicamentos, como opção estratégica no desenvolvimento da indústria no país.

Esse destaque ao software, obviamente, não ocorre por acaso. É o segmento que mais cresce dentro da indústria brasileira de Tecnologia da Informação (hardware, serviços, software); apresenta dinamismo crescente e sustentável; é intensivo em pesquisa e desenvolvimento; relaciona-se diretamente com a inovação de produtos, processos e formas de uso; tem efeito indutor de melhorias em outras cadeias produtivas; e apresenta potencial para o desenvolvimento de vantagens comparativas dinâmicas (CARVALHO JR. 2005 apud ROSELINO, 2006).

Entretanto, o país não possui uma estratégia competitiva para esta indústria que concorra para a sua maior inserção internacional. Dificuldades de financiamento são algumas das barreiras à competitividade desta indústria no plano internacional. Este é o ponto contemplado pelo governo na PITCE (Governo Federal, 2003).

Assim, as principais metas traçadas ao desenvolvimento da indústria de software são: i) transformar o Brasil em referência na exportação de software e serviços correlatos; e ii) promover uma "ampliação significativa" da presença das empresas nacionais no mercado interno.

Nesta nova configuração de política, outros atores passam a ter papel significativo na promoção da indústria nacional de software. Dentre estas, destacase a reformulação do papel do BNDES, com o relançamento do programa de apoio à indústria de software, em abril de 2004, o "novo Prosoft" - Programa para o Desenvolvimento da Indústria Nacional de Software e Serviços Correlatos. O papel do programa, como o próprio nome diz, é contribuir para o desenvolvimento da indústria nacional de software e serviços correlatos, de forma a:

- ampliar significativamente a participação das empresas nacionais no mercado interno; 
- promover o crescimento de suas exportações;

- fortalecer o processo de P\&D e inovação no setor de software;

- promover o crescimento e a internacionalização das empresas nacionais de software e serviços correlatos;

- promover a difusão e a crescente utilização do software nacional por todas as empresas sediadas no Brasil e no exterior;

- fomentar a melhoria da qualidade e a certificação de produtos e processos associados ao software.

A atuação do BNDES pode vir a contribuir para a competitividade das empresas nacionais através da provisão de meios de acesso à um sistema financeiro que ofereça custos menos elevados, assim como proporcionar condições para a consolidação das empresas nacionais em operações de fusões e aquisições (STEFANUTO e CARVALHO, 2005).

Outro ator importante neste contexto é a Financiadora de Estudos e Projetos (FINEP) com projetos voltados à industria brasileira de software e a criação de uma biblioteca de componentes com a possível utilização de módulos e partes reutilizáveis de software.

O Instituto Nacional de Metrologia, Normalização e Qualidade Industrial (INMETRO) também é responsável pelo desenvolvimento de programa nacional voltado à capacitação de instituições nacionais para certificação de qualidade em software e serviços (MENEZES et al, 2005).

Outro importante marco institucional para a atividade de software no Brasil é a Sociedade SOFTEX - organização não-governamental, e sua rede de agentes e núcleos espalhados pelo país responsáveis por prestar assessoria em marketing, tecnologia e finanças, além de promover cursos de capacitação envolvendo um grande número de empresas e instituições, disseminando a cultura do empreendorismo, e promovendo a exportação de software das empresas nacionais. 
Pode-se dizer que a SOFTEX representa um dos mais importantes instrumentos de fomento voltado ao desenvolvimento da indústria brasileira.

\subsection{Dados sobre a Indústria Brasileira de Software}

A indústria de software no Brasil ainda é pouco conhecida. Como já comentado anteriormente, há uma grande dificuldade em se lidar com dados e estatísticas relativas às atividades de software devido a trabalhos executados paralelamente com diferentes critérios empregados nas abordagens utilizadas, divergências metodológicas, falta de uniformização dos conceitos envolvidos e outros fatores, bem como pela difícil definição dos contornos da atividade, dada a transversalidade do software em diferentes cadeias produtivas nos mais diversos setores econômicos (ROSELINO, 2006). Outra grande dificuldade é manter dados atualizados. Desta forma, quem se interessa em pesquisar o setor tem que trabalhar em condições, às vezes, precárias.

Algumas instituições (Assespro, Sepin, Sociedade Softex, Sebrae, Finep, Bndes, lees e outras) têm se preocupado por acompanhar o setor, mas as informações ainda são precárias, em parte por se tratar de um setor jovem e dinâmico. No final de 2007, a SOFTEX, com apoio do Ministério de Ciência e Tecnologia, e o Instituto Brasileiro de Geografia e Estatística (IBGE) firmaram um acordo para a implantação de um Sistema de Informações da Indústria Brasileira de Software. Espera-se que com isso, o setor passe a ter uma fonte de dados atual e confiável.

Segundo a Associação Brasileira de Empresas de Software (ABES, 2006), um dos órgãos representativos do setor, o mercado brasileiro de software e serviços ocupa a $12^{a}$ posição no mercado mundial, tendo movimentado em 2005, aproximadamente 7,41 bilhões de dólares, o equivalente a 0,95\% do PIB no mesmo ano. Deste total, 2,72 bilhões foram de movimentações em software, representando aproximadamente $1,2 \%$ do mercado mundial e $41 \%$ do mercado latino-americano. A 
movimentação dos 4,6 bilhões restantes foi em serviços correlatos. Estudos apontam para um crescimento médio anual superior a 11\% até 2009.

Parte significativa do mercado de software brasileiro ainda é composto por programas desenvolvidos no exterior, na ordem de aproximadamente $71 \%$. Porém, projeções futuras indicam a diminuição desta participação para $66 \%$ até o final da década. São aproximadamente 7760 empresas que alimentam esse mercado, dedicadas ao desenvolvimento, produção e distribuição de software e prestação de serviços.

Das empresas que atuam no desenvolvimento e produção de software, 94\% são classificadas como micro e pequenas empresas, sendo o mercado brasileiro impulsionado em grande parte por estas empresas. Há uma concentração maior de consumidores de software e serviços, sendo os setores financeiro e industrial representantes de $50 \%$ do mercado usuário, seguido por serviços, comércio, governo, agroindústria e outros. A figura 3.2 apresenta os principais indicadores do mercado brasileiro. 


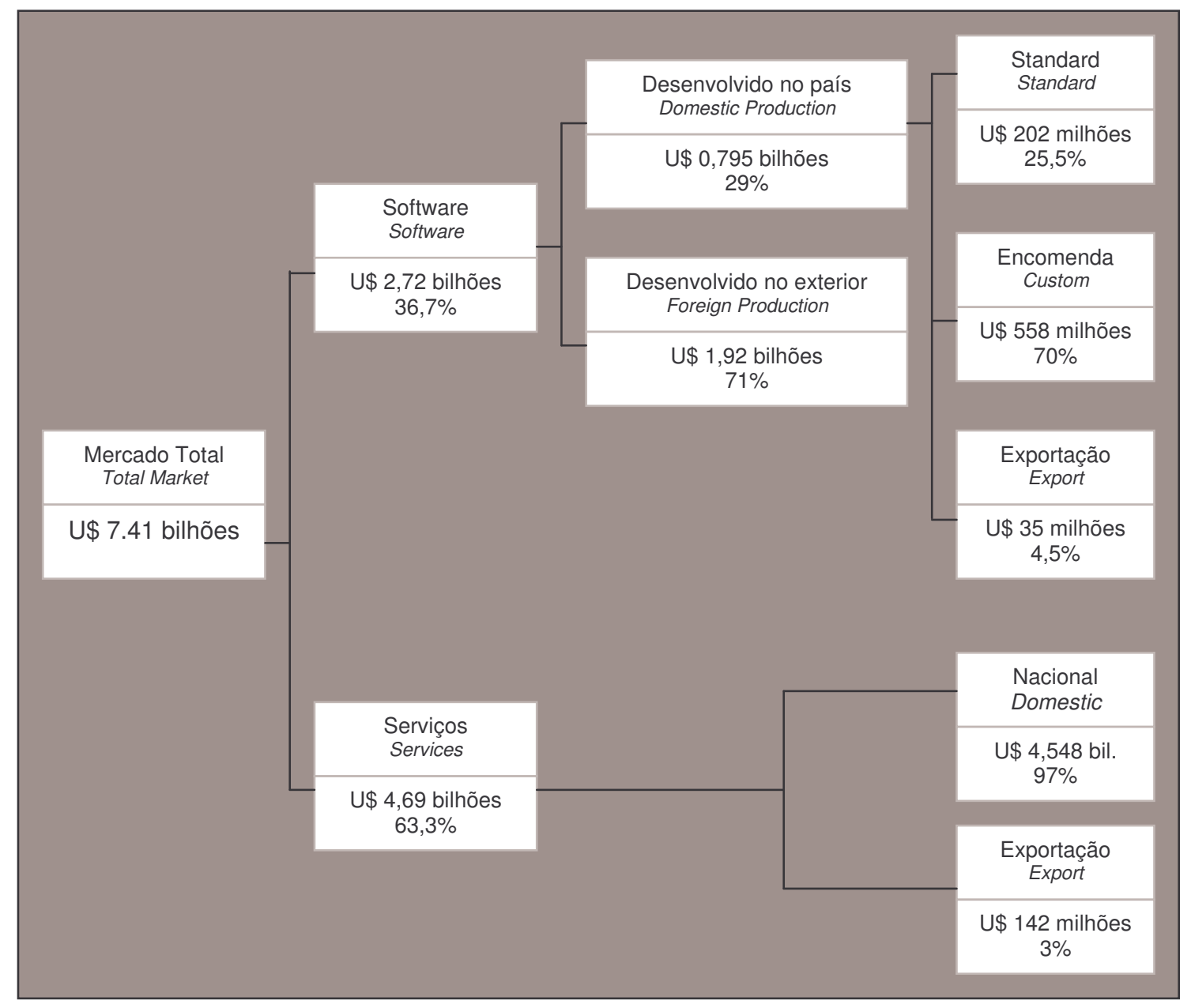

Figura 3.2 - Principais Indicadores do Mercado Brasileiro - 2005

Fonte: ABES, 2006

Apesar do fato do Brasil ter perdido algumas posições no mercado mundial de software e serviços nas últimas estatísticas, ainda pode ser considerado entre os maiores do mundo, conforme tabela 3.4. 
Tabela 3.4 - Mercado Mundial de Software e Serviços

\begin{tabular}{|c|c|c|}
\hline PAís & VOLUME (US\$ bilhões) & PARTICIPAÇÃO (\%) \\
\hline USA & 287,5 & 43,4 \\
\hline Japão & 63,2 & 9,5 \\
\hline UK & 59,5 & 9,0 \\
\hline Alemanha & 41,3 & 6,2 \\
\hline França & 36,8 & 5,5 \\
\hline Canadá & 17,9 & 2,7 \\
\hline Itália & 16,9 & 2,5 \\
\hline Áustria & 16,2 & 2,4 \\
\hline Espanha & 11,6 & 1,7 \\
\hline Suécia & 10,1 & 1,5 \\
\hline Holanda & 9,5 & 1,43 \\
\hline Brasil & $\mathbf{7 , 2 3}$ & $\mathbf{1 , 0 9}$ \\
\hline Suíça & 6,9 & 1,05 \\
\hline China & 6,9 & 1,05 \\
\hline Bélgica & 6,3 & 0,95 \\
\hline ROW & 64,17 & 9,8 \\
\hline Total & $\mathbf{6 6 2}$ & $\mathbf{1 0 0} \%$ \\
\hline
\end{tabular}

Fonte: ABES (2006).

Segundo estimativas mais recentes da ABES (2006), o mercado local de software gira em torno de US\$2,72 bilhões, contando com 6.040 empresas, com exportação de US\$ 35 milhões em licenças. E o mercado total de serviços tem como receita aproximada de US $\$ 4,69$ bilhões, contando com 1.720 empresas dedicadas à exploração econômica, com exportação de US\$ 142 milhões.

Quanto à capacidade instalada da indústria, do total de 7.760 empresas explorando economicamente 0 setor: 1.850 empresas dedicam-se ao 
desenvolvimento e produção de software; 4.190 são dedicadas à distribuição e revenda de software; e 1.720 voltadas à prestação de serviços.

Quanto ao desenvolvimento regional da indústria, este ocorreu de forma desigual como várias outras atividades econômicas do país. De acordo com dados da RAIS (2003), a região Sudeste possuía 47,8\% das empresas brasileiras desenvolvedoras de software, obtendo o maior nível de ocupação regional. A região Sul, Centro-Oeste, Nordeste e Norte, respectivamente, 11,1\%, 22,3\%, 9,5\% e 1,7\%.

A grosso modo, segundo Stefanuto (2004), pode-se afirmar que as principais características da indústria de software são: i) ausência de um projeto nacional para o setor; ii) baixa inserção internacional; iii) baixa experiência em mercados internacionais; iv) elevada participação de empresas transnacionais; v) baixo nível de cooperação entre as empresas; vi) falta de financiamento e tratamento fiscal adequados à dinâmica produtiva da indústria; vii) elevadas taxas relacionadas à pirataria; viii) predomínio de serviços de alto valor agregado; ix) presença de grande mercado potencial (serviços financeiros, e-governement e telecomunicações); $x$ ) mão-de-obra qualificada a preços baixos; xii) elevada concentração geográfica na região Sudeste; xii) rápida expansão dos serviços de telecomunicações.

Quanto à origem do conhecimento tecnológico das empresas brasileiras, pesquisa realizada pela MIT SOFTEX (2003) apontou que, em 62\% dos casos é decorrente de esforços internos à empresa, entretanto, com elevada participação dos produtos importados e relacionamentos com clientes. Apenas $20 \%$ da amostra das empresas pesquisadas utilizavam tecnologias em conjunto e/ou produzidas pelas universidades. A falta de elos com o sistema de Ciência e Tecnologia nacional é uma clara característica da dependência tecnológica da indústria brasileira.

Com dimensões similares a de outros casos reconhecidos de sucesso (como, Índia, Irlanda, China ou Israel), a indústria brasileira caracteriza-se como a que apresenta um desempenho exportador mais limitado (ROSELINO, 2006; STEFANUTO, 2002). Entretanto, segundo Roselino (2006), há grande deficiência a respeito de dados sobre a comercialização de software no exterior e inexiste na 
literatura qualquer indicador confiável, com referências consistentes e claras com respeito à metodologia de coleta de informações adotadas.

O que observa-se é que a política setorial deveria se concentrar mais aos potenciais efeitos transformadores do desenvolvimento e aplicação do software aos problemas brasileiros, como instrumento de promoção do desenvolvimento econômico e social da nação, e, talvez dar menos ênfase à tarefa inútil de replicar "modelos exportadores", que às vezes demonstram atividades vultosas, com mínimos avanços num desenvolvimento tecnológico e produtivo mais virtuoso (ROSELINO, 2006).

\subsection{O Processo de Software}

O software pode ser abordado sob dois pontos de vista: Produto e Processo, sendo que há uma conscientização de que a qualidade do produto de software está fortemente determinada pela qualidade do processo utilizado durante o seu desenvolvimento e manutenção (PFLEEGER, 2001). Em outras palavras, além da necessidade de melhoria da qualidade do produto final, que é resultante do processo de desenvolvimento, as organizações precisam se preocupar cada vez mais com o aprimoramento do processo como forma de garantir a qualidade do produto em si (SOMMERVILLE, 2003).

Como definição, o processo de software pode ser descrito como o conjunto de "atividades e informações associadas que são necessárias para o desenvolvimento de um sistema de software" (SOMMERVILLE, 1996). Entretanto, tais processos possuem peculiaridades que os diferenciam dos processos industriais tradicionais, uma vez que a conformidade do produto resultante não pode ser prontamente ou economicamente verificada, requerendo monitorização e controle contínuos dos parâmetros de processo para assegurar que os requisitos especificados sejam atingidos. Assim, o processo de software é referenciado na mais recente versão da Norma NBR /ISO 9000:2000 (Sistema da Qualidade - Fundamentos e Vocabulário) como um "Processo Especial" (ABNT, 2000). 
Esta singular característica conferida ao processo de software também é dada, não apenas em virtude da difícil monitorização do processo, mas porque este é realizado através de um esforço coletivo de criação. Seus resultados dependem diretamente das pessoas, das organizações e procedimentos utilizados em sua construção (FUGETTA, 2000).

De acordo com a ISO/IEC 12207 (ISO, 1995), o processo de desenvolvimento de software inclui quatro processos fundamentais e comuns para todos os projetos:

- Definicão dos requisitos: neste processo são analisadas as funcionalidades pretendidas do sistema a ser desenvolvido, ou seja, são especificados os seus requisitos, incluindo a descrição das suas funções e capacidades, requisitos de negócio, organizacionais e de usuários, de proteção, de segurança, de fatores ergonômicos, de interface, de operações e manutenção, restrições de projeto e requisitos de qualificação.

- Design do sistema: os requisitos de software são desenhados ou transformados numa arquitetura que descreve sua estrutura de alto nível e identifica os seus componentes que devem ser posteriormente refinados para facilitar o projeto detalhado. Um projeto detalhado deve ser elaborado para cada componente, de forma que estes tenham condições de serem refinados em níveis mais baixos, contendo unidades de software que possam ser codificadas, compiladas e testadas.

- Implementação: nesta etapa o design do software é codificado, compilado e testado, para ser transformado em rotinas de software com instruções que podem ser executadas pelos computadores.

- Integração e testes: nesta etapa, é elaborado um plano de integração pelo desenvolvedor; são integradas as diferentes rotinas de software e testado o sistema completo.

- Operação: o sistema de software desenvolvido entra em execução e passa a ser operado nas diferentes atividades organizacionais. 
Maldonado (in ROCHA et al, 2001) referindo-se ao processo de software, define como condição para a sua qualidade, que este se caracterize como uma atividade sistemática e passível de repetição, independentemente de quem o execute.

A complexidade para a obtenção da qualidade no software, em virtude das características peculiares do seu processo influenciou o desenvolvimento de modelos específicos de melhoria de processos de software e de sistemas de gestão da qualidade para software.

\subsection{Melhoria de Processo de Software e Qualidade}

O objetivo de qualquer empresa de software é produzir software de qualidade, nos prazos estabelecidos. Entende-se por software de qualidade, aquele que obtém a satisfação do cliente, incluindo produto e serviço. Para isso, a boa engenharia de software deve incluir uma estratégia para produzir software de qualidade (PFLEEGER, 2001).

Feigenbaun (1991) aponta a qualidade como um conjunto de prioridades relacionadas de modo simultâneo ao produto e ao processo. Essa é uma definição razoavelmente recente, pois até poucos anos, o foco principal do debate em relação à qualidade de software se concentrava nos aspectos determinantes da qualidade dos produtos e seus componentes. Entretanto, nos dias de hoje é senso comum assegurar os níveis desejados de qualidade do produto através da garantia da qualidade do processo produtivo (NOGUEIRA, 2006).

Dada esta importância, vários trabalhos têm abordado esse tema e um grande número de modelos voltados à definição e melhoria dos processos de software têm sido estabelecidos. A Melhoria de Processo de Software (MPS) ou 
Software Process Improvement (SPI) é uma abordagem para melhoria de uma organização intensiva em software por meio da melhoria de processos relevantes baseada no conceito de capacidade de processo (process capability) buscando melhores resultados de um negócio tendo como referência um (ou mais) modelo(s) de capacidade e/ou maturidade (SALVIANO, 2006).

Os modelos provêm uma escala de medição e roteiro sequencial para melhoria. Neles de forma geral são recomendados práticas e procedimentos considerados necessários para assegurar a qualidade dos processos. Definem "o que" e "quão bem" deve ser feito, mas não o "como fazer", o que flexibiliza sobremaneira o modo com que tais padrões podem ser implementados, o que pode, inclusive, comprometer os resultados dessa implementação (NOGUEIRA, 2006). Isto faz com as empresas tenham que desenvolver e/ou buscar caminhos próprios que a levem a alcançar os objetivos pretendidos. Tal fato, aponta para a importância da troca de informações e conhecimentos interorganizacional.

Dentre os modelos de capacidade de processo, alguns possuem maior destaque: o Software Capability Maturity Model (SW/CMM) do Software Engineering Institute (SEI) da Carnegie Mellon University que foi referência base para um modelo mais aperfeiçoado, o Capability Maturity Model Integration (CMMI) da mesma instituição; a Norma ISO/IEC 12207 e suas emendas e mais recentemente o MPS.BR, modelo de referência para Melhoria de Processo do Software Brasileiro.

\subsubsection{O modelo Software Capability Maturity Model (SW-CMM)}

O SW-CMM (Software Capability Maturity Model) é uma aplicação de conceitos de gestão de processos e de melhoria da qualidade para o desenvolvimento e manutenção de software (PAULK et al. 1993). Segundo Pessôa e Spínola (2001), o SW-CMM pode ser definido como uma aplicação criteriosa de conceitos de gestão de software e melhoria da qualidade no desenvolvimento e manutenção de software; um guia de propriedade da comunidade de software; um 
modelo para a melhoria organizacional e a estrutura básica para métodos confiáveis de avaliação.

O modelo foi desenvolvido pelo Software Engineering Institute (SEI), organismo criado pelo Departamento de Defesa do governo norte-americano em conjunto com a Carnegie Mellon University, como resposta a frequentes problemas nas contratações de software que este realizava (NOGUEIRA, 2006). Baseia-se em 5 níveis de maturidade, através dos quais, uma organização pode evoluir de processos imaturos para processos maduros (figura 3.3). Com o foco em projetos de desenvolvimento de software, cerca de "400 boas práticas" são gradualmente implementadas num modelo evolutivo.

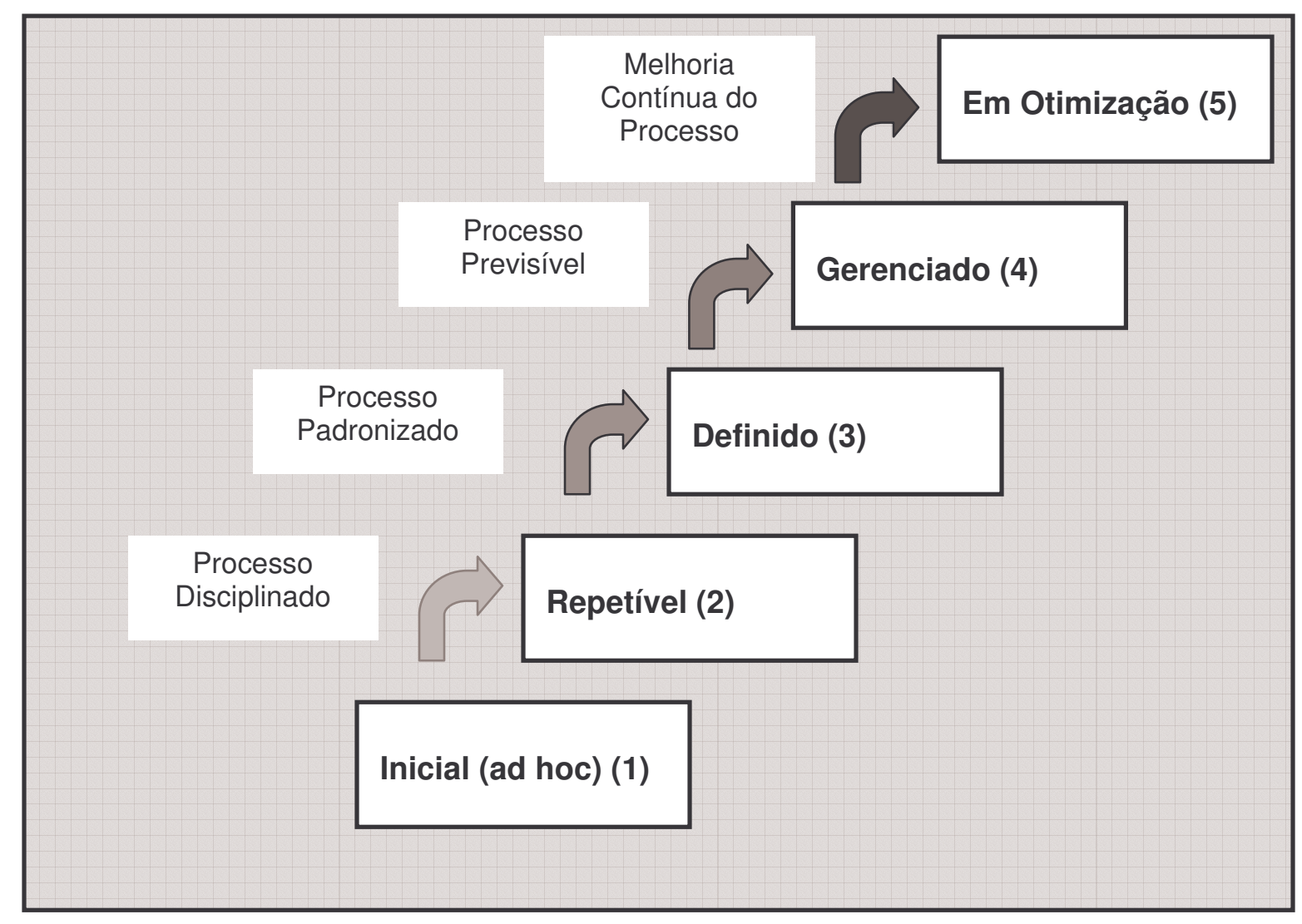

Figura 3.3 - Representação do Modelo CMM

Fonte: Paulk et. al. (1995)

Os níveis de capacidade apresentados na figura são utilizados como escala para pontuação de avaliação e roteiro racional para a melhoria de processo, determinando o estágio na maturidade dos processos da organização. No nível (1) o 
processo de desenvolvimento é desorganizado, sem padrão de qualidade e sem controle (é improvisado); poucos processos são definidos e o sucesso depende dos esforços individuais. No nível (2), os processos básicos de gerenciamento de projeto estão estabelecidos e satisfazem os requisitos definidos de qualidade, prazo e custos; é possível repetir o sucesso de um processo utilizado anteriormente em outros projetos semelhantes. No nível (3), os processos de software, tanto para atividades de gerenciamento, quanto de engenharia são executados e gerenciados com uma adaptação de um processo padrão eficaz e eficiente compreendido pela organização; há garantia da qualidade, tanto de produto como de processo. No nível (4), o processo é executado, gerenciado e padronizado dentro de limites de controle; é monitorado através de medições detalhadas e consistentes que estabelecem as base para uma avaliação dos produtos de software; produto e processo são igualmente compreendidos e rigorosamente controlados quantitativamente. No nível (5), toda a organização está focada na melhoria contínua do processo de forma disciplinada; são utilizadas sistemáticas de análise de causas de defeitos; análise do processo para prevenir a recorrência de defeitos; lições aprendidas são disseminadas para outros projetos e pouco a pouco o processo é incrementado sem maiores impactos organizacionais.

Com exceção do Nível (1), os demais níveis são compostos por "áreas-chave de processos", que caracterizam-se como processos que a organização deve compulsoriamente implementar para que possa ser considerada apta no nível de maturidade. Para cada uma das "áreas-chave", o modelo estabelece de dois a quatro objetivos a serem alcançados. As características comuns de cada uma das "áreas-chave" incorporam um conjunto de "práticas-chave" ou de "boas práticas", que vão contribuir para atingir os objetivos de cada "área-chave de processo". Assim, para que uma organização seja considerada como possuidora de um determinado nível de maturidade CMM, deve ser capaz de evidenciar a realização de todas as "áreas-chave de processo" daquele determinado nível, além de, obviamente, todas as "áreas-chave de processo" de todos os níveis precedentes (NOGUEIRA, 2006). 


\subsubsection{O modelo Capability Maturity Model Integration (CMMI)}

O modelo Capability Maturity Model Integration (CMMI) é uma evolução do modelo Capability Maturity Model (SW/CMM). Na prática, este modelo tem substituído o anterior (CMM). Consiste nas melhores práticas referentes ao desenvolvimento e manutenção de produtos e serviços de software, cobrindo o ciclo de vida do sistema, desde sua concepção até sua entrega e manutenção (CMU/SEI, 2002a). Passou a incorporar áreas de conhecimento que são essenciais ao desenvolvimentos dos sistemas, tais como: engenharia de sistemas, engenharia de software, processo de desenvolvimento integrado do produto, gestão do fornecimento e gestão de processos e projetos (FLEURY, 2007). Todas essas disciplinas foram concebidas de modo a se complementarem de modo coerente e consistente.

Outra alteração importante introduzida a partir do modelo CMMI foi o estabelecimento de duas representações distintas do modelo, que dão origens a duas abordagens: "Representação Contínua" e "Representação por Estágios" (PÊSSOA, 2005). Ambas representações definem modelos evolutivos, definidos em termos de "Níveis de Maturidade" (6 Níveis para "Representação Contínua" e 5 a "Representação por Estágios") (CMU/SElb.) A "Representação Contínua" permite que sejam selecionadas as áreas de melhoria mais importantes para que os objetivos do negócio sejam atingidos e os riscos dos processos minimizados. A "Representação por Estágios" representa uma sequência de melhorias, inicialmente com práticas gerenciais básicas até chegar aos procedimentos de otimização de processos.

Os níveis de capacidade do CMMI por "Representação Contínua" são os seguintes (PÊSSOA, 2003):

- Nível (0) - INCOMPLETO: o processo não é executado ou é executado parcialmente. 
- Nível (1) - EXECUTADO: o processo satisfaz metas específicas da área de processo.

- Nível (2) - GERENCIADO: o processo é planejado, executado, monitorado e controlado para atingir um objetivo.

- Nível (3) - DEFINIDO: o processo gerenciado é adaptado de um conjunto de processo padrão da organização.

- Nível (4) - GERENCIADO QUANTITATIVAMENTE: o processo utiliza técnicas estatísticas e métodos quantitativos de gerenciamento.

- Nível (5) - OTIMIZADO: O processo é gerenciado quantitativamente, tendo como foco sua melhoria contínua.

Os níveis de capacidade de processo por "Representação por Estágios" são os seguintes (PÊSSOA, 2003):

- Nível (1) - INICIAL: processos sem controle, executados de forma caótica.

- Nível (2) - GERENCIADO: os requisitos são gerenciados e os processos são planejados, executados, medidos e controlados.

- Nível (3) - DEFINIDO: os processos são bem caracterizados e entendidos pela organização e são descritos por padrões, procedimentos, ferramentas e métodos.

- Nível (4) - GERENCIADO QUANTITATIVAMENTE: os subprocessos são controlados com a utilização de técnicas estatísticas ou quantitativas.

- Nível (5) - OTIMIZAÇÃO: os processos são continuamente melhorados, a partir do entendimento estatístico das causas comuns de variação.

Apesar dos dois modelos apresentarem similaridades em seus conteúdos, a diferenciação nas representações proporciona características distintas a cada um deles (figura 3.4). Assim, uma dada organização terá condições de levar em conta os aspectos de diferenciação que melhor atendem os seus objetivos de negócio (CHRISSIS et al., 2003). 


\begin{tabular}{|l|l|}
\hline \multicolumn{1}{|c|}{ Representação Contínua } & \multicolumn{1}{c|}{ Representação por Estágios } \\
\hline $\begin{array}{l}\text { Enfoque na melhoria de desempenho de um } \\
\text { processo único }\end{array}$ & $\begin{array}{l}\text { Enfoque de melhoria do processo de forma } \\
\text { sistêmica e estruturada }\end{array}$ \\
\hline $\begin{array}{l}\text { Melhoria de desempenho de várias áreas } \\
\text { alinhadas aos objetivos de negócio da } \\
\text { organização }\end{array}$ & $\begin{array}{l}\text { O atingimento de cada um dos estágios } \\
\text { assegura a fundamentação necessária para } \\
\text { atingir o próximo estágio }\end{array}$ \\
\hline $\begin{array}{l}\text { Níveis de Maturidade utilizados para medir as } \\
\text { melhorias em cada processo individualizado }\end{array}$ & $\begin{array}{l}\text { Áreas de Processo organizadas em níveis de } \\
\text { maturidade }\end{array}$ \\
\hline $\begin{array}{l}\text { Permite a melhoria de diferentes processos } \\
\text { com distintos Níveis de Maturidade }\end{array}$ & $\begin{array}{l}\text { Possibilita que a organização tenha um } \\
\text { referencial evolutivo pré-definido para a } \\
\text { melhoria }\end{array}$ \\
\hline $\begin{array}{l}\text { É imperativo que se tenha o conhecimento } \\
\text { das dependências e interações entre as } \\
\text { diversas Áreas de Processo }\end{array}$ & $\begin{array}{l}\text { Permite a implantação de um processo de } \\
\text { melhoria sem que se identifique qual } \\
\text { processo deve ser priorizado }\end{array}$ \\
\hline $\begin{array}{l}\text { Apropriado quando se conhece qual } \\
\text { processo precisa se melhorado }\end{array}$ & $\begin{array}{l}\text { Possui grande número de estudos de casos } \\
\text { e dados históricos de práticas bem sucedidas } \\
\text { baseados no modelo predecessor, o SW- } \\
\text { CMM }\end{array}$ \\
\hline $\begin{array}{l}\text { Alinhado com a ISO/IEC15504 em função da } \\
\text { Figura }\end{array}$ & $\begin{array}{l}\text { Provê uma migração mais simples do modelo } \\
\text { CMM para o CMMl }\end{array}$ \\
\hline
\end{tabular}

Figura 3.4 - CMMI: quadro comparativo das características das representações contínua e por estágios

Fonte: CHRISSIS et al. (2003).

\subsubsection{A Norma ISO/IEC 12207 - Processo de ciclo de vida de software}

A Norma ISO/IEC 12207 propõe uma estrutura comum para os processos de ciclo de vida de software [...] entendendo-se processos como "conjunto de recursos e atividades inter-relacionados que transformam insumos (entradas) em produtos (saídas)" (NBR ISO 8402:1994). Desta maneira, categoriza e apresenta os processos que compõem o ciclo de vida completo do software, desde sua concepção até sua manutenção e descontinuidade (FLEURY, 2007).

A norma foi concebida para ter uma aplicação genérica. Para isso, contém um conjunto de processos, atividades e tarefas projetado para ser adaptado de acordo 
com cada projeto de software. Apresenta 3 categorias principais de processos, e classifica-os como:

Processos Fundamentais: contempla os processos de Aquisição, Fornecimento, Desenvolvimento, Operação e Manutenção.

Processos de apoio ao ciclo de vida: contempla os processos de Documentação, Gerência de Configuração, Garantia da Qualidade, Verificação, Validação, Revisão Conjunta, Auditoria e Resolução de Problema.

Processos organizacionais de ciclo de vida: é composto por Gerência, Infraestrutura, Melhoria e Treinamento.

A norma sugere uma lista de atividades e tarefas que compõem o processo. A execução do processo ou a conclusão de uma atividade é realizada quando todas as tarefas requeridas são executadas de acordo com os critérios preestabelecidos e os requisitos especificados.

\subsubsection{A Norma ISO/IEC 15504 - Information Technology - process assessment}

A norma é constituída por dimensões de processos e o nível de capacidade é demonstrado através de atributos. Essas dimensões são classificadas em 5 grupos de processos:

- Processos de fornecimento à clientes: referem-se à prestação de serviços propriamente dita.

- Processos de engenharia: estão relacionados aos processos necessários para a construção dos produtos e serviços.

- Processos de suporte: têm a finalidade de prestar apoio aos demais processos.

- Processos de gestão: dizem respeito à gestão de projetos e serviços em várias dimensões, tais como, qualidade, risco, subcontratos.

- Processos de organização: dizem respeito à definição e melhoria dos processos. 
Deve ser chamada a atenção ao fato de que a norma define tarefas a serem executadas, mas não estabelece a maneira como isso deve ser feito. Este como fazer se traduz no conjunto de práticas e técnicas adotadas por cada organização em particular para a execução das diversas tarefas inerentes aos processos (NOGUEIRA, 2006).

\subsubsection{Melhoria de Processo do Software Brasileiro - MPS.BR}

Desde 1993, com a criação do Programa Brasileiro da Qualidade e Produtividade de Software (PBQP Software), o Brasil tem investido na melhoria contínua da qualidade de software (WEBER e PINHEIRO, 1995). O Ministério da Ciência e Tecnologia - MCT, através da Secretaria de Política de Informática vem conduzindo periodicamente uma pesquisa de campo junto à uma parcela significativa das empresas desenvolvedoras de software no Brasil. O objetivo é delinear o perfil e a evolução no uso dos princípios de gestão da qualidade e das técnicas de qualidade específicas para o desenvolvimento de software. Os resultados são divulgados em um documento intitulado "Qualidade e Produtividade no Setor de Software Brasileiro". No início dos anos 2000, estudos mostravam que era necessário um esforço significativo para aumentar a maturidade dos processos de software nas empresas brasileiras (MCT/SEPIN, 2001).

Conforme a tese de NOGUEIRA (2006) que fez uma análise do comportamento dos indicadores da pesquisa do MCT sobre qualidade e produtividade no setor de software brasileiro, há um processo contínuo e acelerado de amadurecimento da indústria de software no Brasil. Entretanto, ainda há um longo caminho a ser percorrido a fim de que esta alcance os patamares de desenvolvimento desejáveis. A incorporação da qualidade como componente da cultura das organizações não pôde ainda ser percebido como característica inerente à indústria brasileira. 
Um estudo do Massachussetts Institute of Technology (MIT) constatou que houve interesse na melhoria de processos de software no Brasil nos últimos anos e que as empresas nacionais optaram pela certificação ISO 9001 em detrimento de outros modelos e padrões especificamente voltados para software (VELOSO et al., 2003).

$\mathrm{Na}$ análise deste problema foi constatado que uma das maiores barreiras à adoção de outros modelos mais específicos do setor, tais como o CMM, era o custo elevado destas avaliações (dezenas de milhares de dólares), sobretudo para as pequenas e médias empresas (PME's) que não podiam pagá-los, embora necessitassem melhorar seus processos de software para aumentar a competitividade. Assim, a implementação e avaliação do modelo têm ficado restritas às grandes empresas do mercado, em sua maioria filiais de corporações multinacionais (WEBER e ARAÚJO, 2007).

Esta situação motivou a SOFTEX (Sociedade para Promoção da Excelência do Software Brasileiro) a lançar em 11 de dezembro de 2003, o Projeto MPS.BR Melhoria de Processo do Software Brasileiro como um modelo de referência voltado à realidade da indústria brasileira. O MPS.BR pode ser considerado também uma referência que preconiza o desenvolvimento econômico com base em um modelo estratégico de negócio cooperado de redes de pequenas e médias empresas que será detalhado adiante.

O programa envolve universidades, grupos de pesquisa, instituições implementadoras (II), instituições avaliadoras (IA), empresas de software e instituições organizadoras de grupos de empresas (IOGES). Trata-se de um projeto de longo prazo, sem data para término, compreendendo as seguintes fases: i) 20042007: implantação do MPS.BR no Brasil,; ii) 2008-2011: consolidação do MPS.BR.

A proposta do Projeto MPS.BR é desenvolver e disseminar um modelo de melhoria de processos de software junto às empresas brasileiras, especialmente na grande massa de micro, pequenas e médias empresas, a um custo razoável, para que estas possam produzir software de acordo com padrões internacionais da qualidade. O Programa é apoiado pelo Ministério da Ciência e Tecnologia (MCT) e 
pela Financiadora de Estudos e Projetos (FINEP). No mês de abril do ano de 2005, passou a ser apoiado também pelo Banco Interamericano de Desenvolvimento (BID), através do Fundo Multilateral de Investimento (FUMIN) e mais recentemente pelo SEBRAE/PROIMPE (SOFTEX, 2005, WEBER et al. 2006). O projeto possui em sua estrutura um Fórum de Credenciamento e Controle que tem como parte de sua responsabilidade discutir e aperfeiçoar o modelo. Este Fórum é formado por representantes da Sociedade Softex, de Instituições de Ensino, Pesquisa e Centros Tecnológicos e do Governo.

O Programa MPS.BR possui um processo de criação e aprimoramento do modelo MPS e outro de disseminação do modelo. O primeiro processo é técnico e compreende 5 atividades: i) desenvolvimento do Modelo MPS e sua documentação em guias do MPS.BR; ii) capacitação de pessoas através de cursos, provas e workshops; iii) credenciamento de Instituições Implementadoras (II) do MPS.BR; iv) credenciamento de Instituições Avaliadoras (IA) do MPS.BR; v) certificação de Consultores de Aquisição (CA) do MPS.BR. O segundo processo, de aceitação pelo mercado, compreende três atividades: i) criação e aprimoramento do Modelo de Negócio MN-MPS; ii) implementação do Modelo de Referência MR-MPS em organizações interessadas, públicas e privadas; iii) avaliação segundo o método de Avaliação MA-MPS em organizações que adotaram o Modelo MPS.

\section{- Descrição do Modelo MPS.BR}

A estrutura do Modelo MPS inclui 3 componentes:

Modelo de Referência para Melhoria de Processo (MR-MPS),

Método de Avaliação para Melhoria de Processo de Software (MA-MPS),

Modelo de Negócio (Figura 3.5).

Possui as seguintes características: i) conformidade e aderência com as normas ISO/IEC 12207 (Processos do Ciclo de Vida do Software) e ISO/IEC 15504 (Avaliação de Processo); ii) compatibilidade com o Modelo CMMI e ISO/IEC 15504, de modo a prover um modelo de referência evolutivo, através do qual as organizações podem desenvolver um plano de desenvolvimento de longo prazo; iii) 
baseado nas melhores práticas da Engenharia de Software; iv) criado para a realidade das empresas brasileiras, pois contempla a possibilidade de estratégias de implantação específicas para empresas específicas ou para grupos de empresas cooperadas - estratégia esta que facilita sobremaneira sua utilização por empresas de pequeno porte, por dividir custos e dispor de linhas de financiamento (WEBER e ARAÚJO, 2007, NOGUEIRA, 2006, SOFTEX, 2005).

Cada componente do modelo foi descrito através de documentos e guias específicos (figura 3.5). Parte destes: um Guia Geral, um Guia de Avaliação e um Guia de Aquisição, que são apresentados mais adiante (SOFTEX, 2005).

O Guia Geral do MPS.BR é um documento que contém a descrição geral do Programa MPS.BR e os requisitos que as organizações devem atender para estar em conformidade com o modelo. Detalha o Modelo de Referência para Melhoria do Processo de Software (MR-MPS) e apresenta definições necessárias para a sua compreensão e aplicação (WEBER et al., 2006).

A estrutura do Modelo de Referência (MR-MPS) combina conceitos de maturidade, sequenciais e cumulativos (definidos pelo CMMI), com conceitos de capacidade de processo, estabelecidos pela ISO/IEC 15504 (figura 3.6). Cada nível de maturidade é uma junção entre processos e capacidade dos processos. $O$ progresso e o atendimento do nível de maturidade são obtidos quando todos os resultados e propósitos do processo são atendidos, bem como os atributos de processo relacionados àquele nível (SOFTEX, 2005, WEBER et al., 2006). 


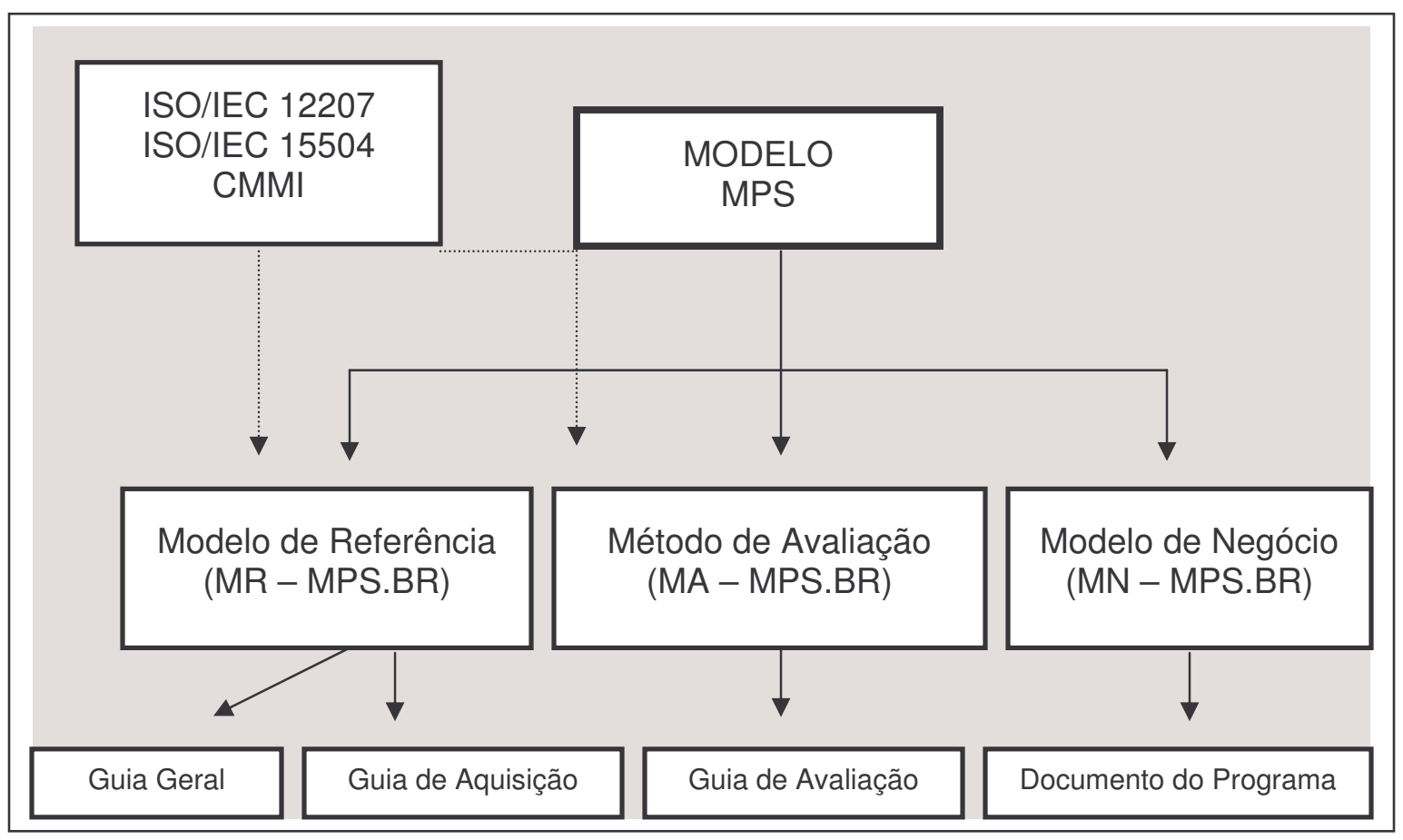

Figura 3.5 - Estrutura do Modelo MPS.BR

Fonte: SOFTEX (2005)

Cabe destacar que a estrutura do modelo MPS.BR tem sido avaliada e aperfeiçoada de modo contínuo. Um guia de implementação foi desenvolvido como proposta de um modelo mais atualizado e prático.

Os níveis de maturidade estabelecem os patamares de evolução dos processos e traçam paralelo com os quatro níveis de maturidade da representação por estágios do CMMI (níveis 2 a 5), sendo os níveis F, C, B e A do MR-MPS correspondentes respectivamente aos níveis 2, 3, 4 e 5 do CMMI. O nível G é um nível intermediário entre os níveis 1 e 2 do $\mathrm{CMMI}$ e os níveis $\mathrm{E}$ e D são dois níveis intermediários entre os níveis 2 e 3 do CMMI.

São 7 os níveis de maturidade do MR-MPS: A (Otimização), B (Gerenciado Quantitativamente), C (Definido), D (Largamente Definido), E (Parcialmente Definido), F (Gerenciado) e G (Parcialmente Gerenciado). Obviamente, o nível G indica que é o mais imaturo e, o nível $A$, o mais maduro. A graduação em sete níveis possibilita uma implementação e reconhecimento mais gradual da melhoria de processo de software, e facilita, portanto, sua adequação às PME's permitindo 
visibilidade dos resultados em prazos mais curtos (WEBER et al., 2006, SOFTEX, 2005).

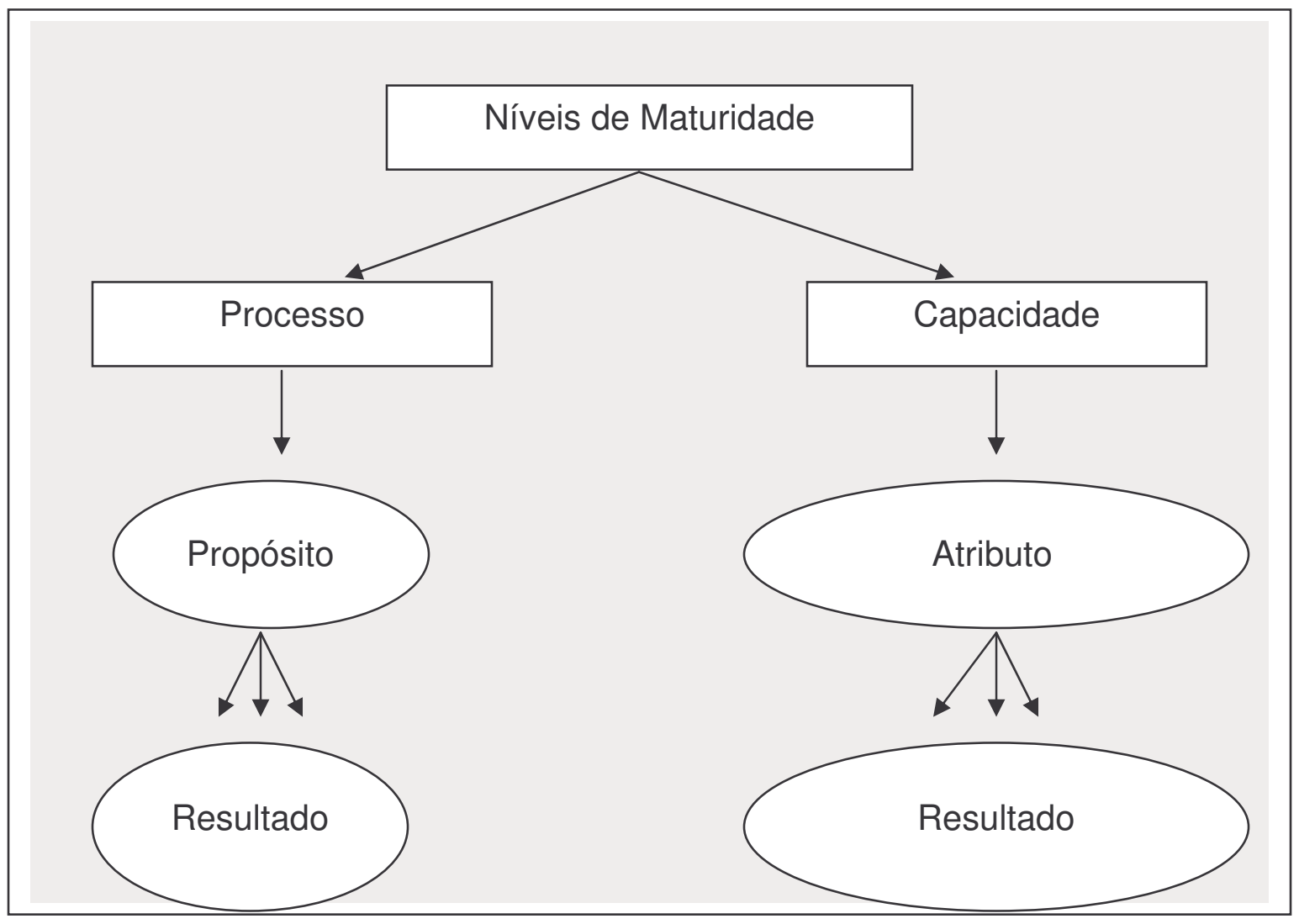

Figura 3.6 - Estrutura do Modelo MR-MPS

Fonte: SOFTEX (2005)

A capacidade do processo do MR-MPS é determinada através de 12 Resultados de Atributos de Processos (RAP) (tabela 3.5): 
Tabela 3.5 - Resultados de Atributo de Processo do MR-MPS

\begin{tabular}{|c|c|}
\hline Atributos de Processo & Resultado de Atributo de Processo \\
\hline $\begin{array}{l}\text { AP } 1.1 \text { O processo é } \\
\text { executado }\end{array}$ & RAP 1. O processo atinge seus resultados definidos. \\
\hline \multirow{8}{*}{$\begin{array}{l}\text { AP } 2.1 \text { O processo é } \\
\text { gerenciado }\end{array}$} & $\begin{array}{l}\text { RAP 2. Existe uma política organizacional estabelecida e mantida } \\
\text { para os processos; }\end{array}$ \\
\hline & RAP 3. A execução dos processos é planejada; \\
\hline & $\begin{array}{l}\text { RAP 4. (para o Nível G). A execução dos processos é monitorada } \\
\text { e ajustes são realizados para atender aos planos; }\end{array}$ \\
\hline & $\begin{array}{l}\text { RAP 4. (a partir do Nível F). Medidas são planejadas e coletadas } \\
\text { para monitoração da execução dos processos; }\end{array}$ \\
\hline & $\begin{array}{l}\text { RAP 5. Os recursos necessários para a execução dos processos } \\
\text { são identificados e disponibilizados; }\end{array}$ \\
\hline & $\begin{array}{l}\text { RAP 6. As pessoas que executam os processos são competentes } \\
\text { em termos de educação, treinamento e experiência apropriados; }\end{array}$ \\
\hline & $\begin{array}{l}\text { RAP } 7 \text {. A comunicação entre as partes envolvidas nos processos é } \\
\text { realizada; }\end{array}$ \\
\hline & $\begin{array}{l}\text { RAP 8. O estado, atividades e resultados dos processos são } \\
\text { revistos com os níveis adequados de gerência (incluindo gerência } \\
\text { de alto nível) e problemas pertinentes são tratados. }\end{array}$ \\
\hline $\begin{array}{l}\text { AP } 2.2 \text { Os produtos de } \\
\text { trabalho do processo } \\
\text { são gerenciados }\end{array}$ & $\begin{array}{l}\text { RAP 9. Os produtos de trabalho são documentados, revistos e } \\
\text { controlados apropriadamente. }\end{array}$ \\
\hline $\begin{array}{l}\text { AP } 3.1 \text { O processo é } \\
\text { definido }\end{array}$ & $\begin{array}{l}\text { RAP 10. Um processo padrão é definido, incluindo diretrizes para } \\
\text { sua adaptação para o processo definido. }\end{array}$ \\
\hline $\begin{array}{l}\text { AP } 3.2 \text { O processo está } \\
\text { implementado }\end{array}$ & $\begin{array}{l}\text { RAP 11. A sequência e interação do processo-padrão com outros } \\
\text { processos são determinadas. }\end{array}$ \\
\hline $\begin{array}{l}\text { AP } 3.2 \text { O processo está } \\
\text { implementado }\end{array}$ & $\begin{array}{l}\text { RAP 12. Dados apropriados são coletados e analisados, } \\
\text { constituindo uma base para o entendimento do comportamento do } \\
\text { processo, para demonstrar a adequação e a eficácia do processo, } \\
\text { e avaliar onde pode ser feita a melhoria contínua do processo. }\end{array}$ \\
\hline
\end{tabular}

Fonte: WEBER et al. (2006), SOFTEX (2005)

A tabela 3.6 apresenta os níveis de maturidade do MR-MPS, os processos e os atributos de processo correspondentes a cada nível. 
Tabela 3.6 - Níveis de Maturidade do MR-MPS e Atributos de Processo

\begin{tabular}{|c|c|c|}
\hline Nível & Nome e Sigla dos Processos & $\begin{array}{l}\text { Atributos de } \\
\text { Processo } \\
\text { (Capacidade) }\end{array}$ \\
\hline $\begin{array}{c}\mathbf{A} \\
\text { (mais } \\
\text { alto) }\end{array}$ & $\begin{array}{l}\text { Implantação de Inovações na Organização - IIO } \\
\text { Análise de Causas e Resolução - ARC }\end{array}$ & $\begin{array}{l}\text { AP 1.1, AP 2.1, AP } \\
2.2, \text { AP } 3.1 \text { e AP } 3.2\end{array}$ \\
\hline B & $\begin{array}{l}\text { Desempenho do Processo Organizacional - DEP } \\
\text { Gerência Quantitativa do Projeto - GQP }\end{array}$ & $\begin{array}{l}\text { AP 1.1, AP 2.1, AP } \\
2.2, \text { AP } 3.1 \text { e AP3.2 }\end{array}$ \\
\hline C & $\begin{array}{l}\text { Gerência de Riscos - GRI } \\
\text { Análise de Decisão e Resolução - ADR }\end{array}$ & $\begin{array}{l}\text { AP } 1.1, \text { AP } 2.1, \text { AP } \\
2.2, \text { AP } 3.1 \text { e AP } 3.2\end{array}$ \\
\hline D & $\begin{array}{l}\text { Desenvolvimento de Requisitos - DRE } \\
\text { Solução Técnica - STE } \\
\text { Validação - VAL } \\
\text { Verificação - VER } \\
\text { Integração do Produto - ITP }\end{array}$ & $\begin{array}{l}\text { AP } 1.1, \text { AP } 2.1, \text { AP } \\
2.2, \text { AP } 3.1 \text { e AP } 3.2\end{array}$ \\
\hline E & $\begin{array}{l}\text { Treinamento - TRE } \\
\text { Definição do Processo Organizacional - DFP } \\
\text { Avaliação e Melhoria do Processo Organizacional - AMP } \\
\text { Adaptação do Processo para Gerência de Projeto - APG }\end{array}$ & $\begin{array}{l}\text { AP } 1.1, \text { AP } 2.1, \text { AP } \\
2.2, \text { AP } 3.1 \text { e AP } 3.2\end{array}$ \\
\hline $\mathbf{F}$ & $\begin{array}{l}\text { Gerência de Configuração - GCO } \\
\text { Garantia da Qualidade - GQA } \\
\text { Medição - MED } \\
\text { Aquisição - AQU }\end{array}$ & $\begin{array}{l}\text { AP } 1.1, \text { AP } 2.1 \text { e AP } \\
2.2\end{array}$ \\
\hline $\begin{array}{c}\mathbf{G} \\
\text { (mais } \\
\text { baixo) }\end{array}$ & $\begin{array}{l}\text { Gerência de Projeto - GPR } \\
\text { Gerência de Requisitos - GRE }\end{array}$ & AP 1.1 e AP 2.1 \\
\hline
\end{tabular}

Fonte: WEBER et al. (2006), SOFTEX (2005)

\section{- Guia de Avaliação}

O Guia de Avaliação contém a descrição do Método de Avaliação para Melhoria de Processo de Software (MA - MPS). É composto pelo processo de avaliação MPS, pelo método de avaliação MPS e características da qualificação dos avaliadores. O processo de avaliação é composto por quatro subprocessos: 
Contratar a avaliação, Preparar a realização da avaliação, Realizar a avaliação. Documentar os resultados da avaliação (figura 3.7). O método de avaliação é feito com base em indicadores: diretos - produtos intermediários; indiretos: documentos que indicam que a atividade foi realizada; afirmação: resultantes de entrevistas. $\mathrm{O}$ resultado da avaliação tem validade por 2 anos.

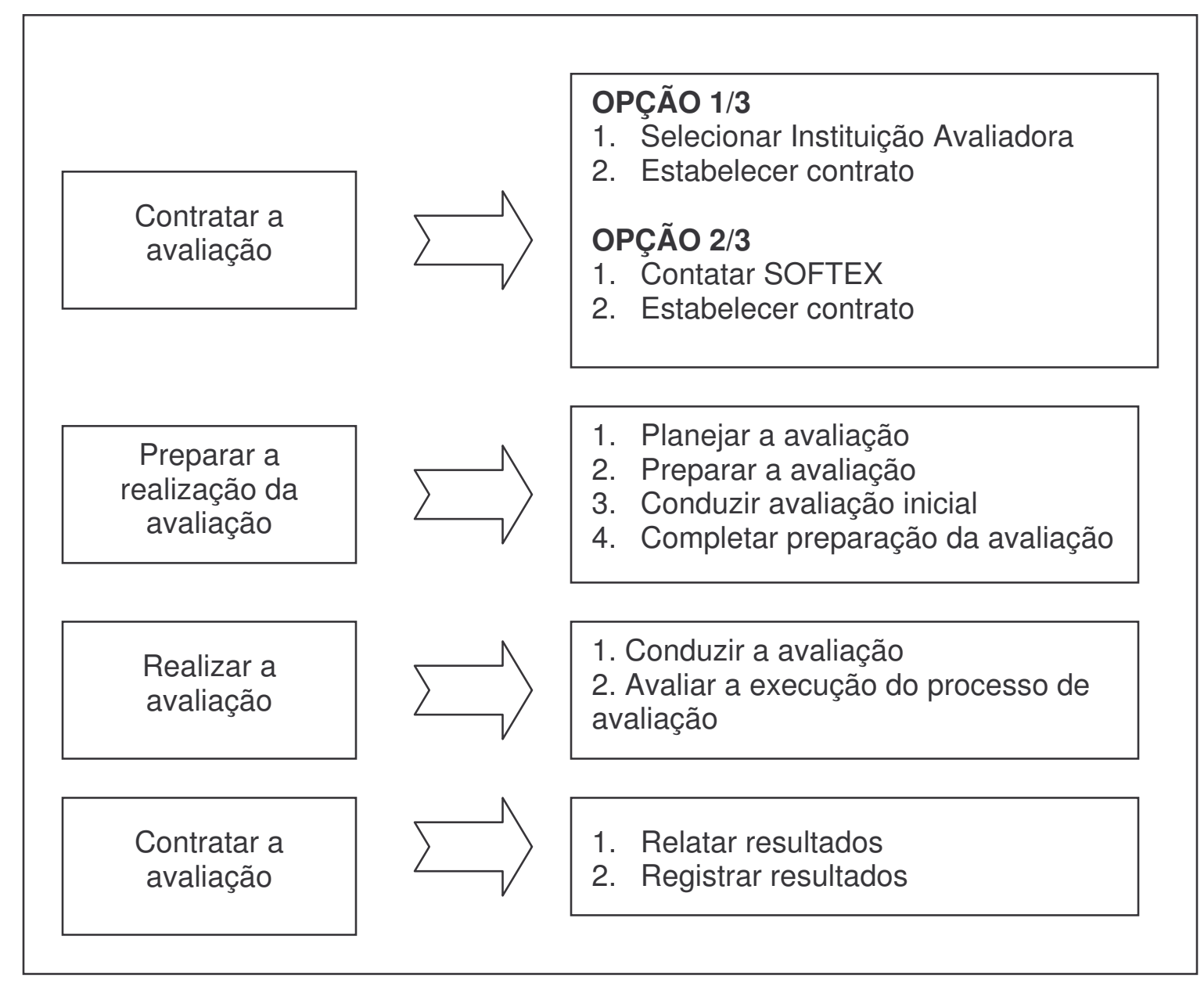

Figura 3.7 - Processo de Avaliação MPS

Fonte: WEBER et al. (2006), SOFTEX (2005)

\section{- Guia de Aquisição}

Descreve um processo de aquisição de software e serviços correlatos (S\&SC), e aborda relacionamentos deste processo com o Modelo MPS. São quatro os subprocessos de Aquisição: Preparação da Aquisição; Seleção do Fornecedor; Monitoração do Fornecedor; e Aceitação pelo Cliente. 


\section{- Modelo de Negócio}

O Modelo de Negócio do Programa MPS.BR é constituído por três domínios inter-relacionados: i) gestão do Programa MPS.BR por responsabilidade da SOFTEX; ii) instituições implementadoras e avaliadoras (II e IA); iii) empresas, grupos de empresas e instituições organizadoras de grupos de empresas (IOGES). O MN - MPS está estruturado de duas formas:

Modelo de Negócio Cooperado (MNC-MPS): adequado para grupos de PME's que necessitam melhorar seus processos de software e que desejam compartilhar custos, experiências e aprendizado;

Modelo de Negócio Específico (MNE-MPS): próprio para empresas de qualquer porte e natureza que não querem compartilhar com outras empresas a melhoria de seus processo de software. (SOFTEX, 2005).

\section{- Instituições Implementadoras (II) e Avaliadoras (IA)}

Até final de 2007 eram 18 instituições credenciadas para promover a implementação do Modelo MPS.BR em empresas e grupos de empresas através de pessoas habilitadas como Consultores de Implementação do Modelo MPS. As instituições possuem formas independentes de implementação, porém devem atender os requisitos do modelo e estarem previamente credenciadas junto ao MPS.BR. São 7 instituições avaliadoras e 11 instituições organizadoras de grupos de empresas credenciadas ao MPS. Até novembro de 2007, o MPS.BR foi implementado em mais de 120 organizações, das quais 93 empresas no Modelo de Negócio Cooperado (MNC). Foram publicadas até esta data 58 avaliações em organizações públicas e privadas.

Tradicionalmente, os organizadores do Programa MPS.BR realizam Workshops anuais de troca de experiências sobre o programa no Brasil, com foco nas lições aprendidas, melhores práticas, aspectos que facilitam o trabalho e dificuldades. O último encontro realizado foi em novembro de 2007 em Belo Horizonte - MG, onde estiveram presentes implementadores e avaliadores, instituições organizadoras de grupos de empresas e empresas. Este último grupo, 
para o I Workshop de Empresas que adotaram o MPS. BR. Nesta ocasião, a pesquisadora deste estudo, esteve presente, onde pôde coletar dados importantes relacionados aos objetivos desta pesquisa. Essas informações estão contidas no capítulo 5 desta tese. 


\section{METODOLOGIA}

Este capítulo tem como objetivo apresentar o percurso metodológico utilizado para alcançar os objetivos traçados para a tese. Assim, serão descritos a abordagem macro da pesquisa, com os requisitos de seleção do método de procedimento, assim como os critérios para a seleção do local. $\mathrm{Na}$ seqüência, discorre-se sobre os instrumentos de pesquisa e procedimentos de registro e coleta dos dados. Os resultados são apresentados no capítulo 5 para fins comparativos e delineamento das conclusões deste trabalho.

\subsection{A pesquisa científica}

A estruturação de qualquer trabalho científico deve amparar-se no sólido apoio de uma discussão metodológica, que deve contribuir como instrumento explicativo de todo o processo de investigação e dos resultados alcançados.

De acordo com Oliveira (1999:17), a pesquisa científica "tem por objetivo estabelecer uma série de compreensões no sentido de descobrir respostas para as indagações e questões que existem em todos os ramos do conhecimento humano".

Esta concepção é ampliada por Cervo e Bervian (2002:63) ao definirem pesquisa como "uma atividade voltada para a solução de problemas teóricos ou práticos, com o emprego de processos científicos" que incluem métodos e ferramentas utilizadas no processo da pesquisa.

Ruiz (2002:48) também destaca a necessidade de intencionalidade e metodologia adequada ao afirmar que "pesquisa científica é a realização concreta de 
uma investigação planejada, desenvolvida e redigida de acordo com as normas da metodologia consagradas pela ciência”.

Thiollent (1986) afirma que um trabalho científico bem conduzido deve utilizarse da metodologia científica, que pode ser entendida, genericamente, como conhecimento geral e habilidade que são necessários ao pesquisador para se orientar no processo de investigação, na tomada de decisões oportunas, seleção de conceitos, hipóteses, métodos, técnicas, instrumentos e dados adequados.

Contudo, os meios e processos selecionados (instrumental metodológico) dependem fundamentalmente do objeto de pesquisa, e devem ser os mais adequados às exigências deste (CERVO e BERVIAN, 2002; MARCONI e LAKATOS, 2005).

A pesquisa científica deve estar alicerçada em um estruturado delineamento de pesquisa, que diz respeito ao processo completo de pesquisa, partindo dos objetivos e finalizando com a apresentação dos resultados finais em um documento padrão. O principal objetivo do delineamento é a garantia que os procedimentos metodológicos escolhidos levem o pesquisado a responder, de forma lógica e formal, à pergunta de pesquisa delineada (CRESWELL, 1994, YIN, 2001).

Neste estudo, o delineamento da pesquisa inicia-se com a apresentação da abordagem macro da pesquisa, com os requisitos de seleção do método de procedimento. Na seqüência, discorre-se sobre os instrumentos de pesquisa e procedimentos de coleta dos dados.

\subsection{Definição da Abordagem Macro da Pesquisa}

A abordagem macro da pesquisa está relacionada aos objetivos do estudo. (GONSALVES, 2001). De acordo com Salomon (1999), o problema é que determina o tipo de pesquisa científica a ser desenvolvida, podendo esta ser de três tipos: 
a) pesquisa exploratória ou descritiva - cujo objetivo é definir melhor o problema a ser investigado, proporcionar insights sobre o assunto, descrever comportamentos ou definir e classificar fatos e variáveis;

b) pesquisa aplicada - com o objetivo de aplicar leis, teorias e modelos na descoberta de soluções ou no diagnóstico de realidades;

c) pesquisa pura ou teórica - objetiva ir além da definição e descrição de problemas privilegiando a interpretação, a explicação e a predição por meio de teorias, leis ou modelos.

De acordo com o problema de pesquisa proposto e dentro dessa conceituação, a pesquisa realizada caracteriza-se como uma pesquisa exploratória, por tratar de um fenômeno contemporâneo dentro de seu contexto real e com indagações teóricas pouco conhecidas. Segundo Mattar (1993), ainda que existam estudos sobre o assunto, a pesquisa exploratória pode ser útil, pois, para um mesmo fato, poderá haver inúmeras explicações alternativas.

Quanto à abordagem da natureza dos dados, as pesquisas podem ser classificadas em dois tipos distintos: positivista ou quantitativa e fenomenológica ou qualitativa (GONSALVES, 2001).

A pesquisa positivista ou quantitativa preocupa-se com mensuração, generalização e a possibilidade de replicar o estudo; faz uso de procedimentos estatísticos e é comumente utilizada para comprovar ou refutar hipóteses. Neste tipo de pesquisa é comum o uso de experimentos de campo e laboratório. Já a pesquisa fenomenológica ou qualitativa busca o entendimento de problemas sociais e/ou humanos, tendo como base uma visão complexa e holística, formada a partir de informações basicamente colhidas a partir de outros seres humanos, é menos estruturada e mais flexível e não tem a preocupação em mensurar ou quantificar informações, não fazendo uso de procedimentos estatísticos. Esse modelo utiliza principalmente a observação participante, entrevistas não-estruturadas ou semiestruturadas na coleta de dados GONSALVES, 2001; GIL, 1996; BRYMAN, 1989, CRESWELL, 2003). 
Segundo Creswell (2003), o enfoque qualitativo é característico nas pesquisas exploratórias e quando as variáveis mais importantes ainda são pouco conhecidas. Em síntese, as principais características recorrentes de uma pesquisa de caráter eminentemente qualitativo, são (MILES e HUBERMAN, 1994):

- são realizadas com base em intenso ou longo contato com o objeto de estudo;

- o pesquisador busca obter uma visão integral do contexto estudado, sobretudo de sua lógica, arranjos e regras;

- busca-se captar as percepções dos atores locais sem pré-conjecturas;

- umas das tarefas mais importantes é a explicação de como os atores se entendem, agem e gerenciam seu dia-a-dia;

- são possíveis muitas interpretações, a partir do material coletado;

- não há instrumental padronizado para analisar os dados, sendo o pesquisador o principal instrumento;

- a maior parte das análises é feita com palavras.

Com base nessas características, fica evidente a adequação da abordagem qualitativa à esta pesquisa que busca entender como é o processo de aprendizado das PME's de software, a dinâmica das relações e do conhecimento em ambientes interativos.

\subsection{Definição do Método de Procedimento da Pesquisa}

A estratégia ou método de pesquisa dependerá do tipo de questão da pesquisa; grau de controle que o investigador tem sobre os eventos; ou o foco temporal (eventos contemporâneos $\mathrm{X}$ fenômenos históricos).

Os principais métodos ou estratégias de pesquisa qualitativas disponíveis são:

i) pesquisa fenomenológica, na qual o pesquisador tenta capturar a essência de experiências humanas em relação a dado fenômeno, vivenciadas pelos 
participantes ao longo de um período de tempo, com a finalidade de desenvolver padrões e relações de significado;

ii) pesquisa etnográfica, na qual o pesquisador estuda um grupo cultural em seu meio natural durante um longo período de tempo, principalmente, observando o comportamento e os valores do grupo;

iii) grounded theory, na qual o objetivo é extrair uma teoria abstrata e genérica de um processo ou interação, baseado (grounded) nas visões dos pesquisados. Isto implica em ter que coletar dados em vários estágios da pesquisa e refiná-los e relacioná-los com categorias de informação, que formam a base da contínua comparação;

iv) estudo de caso, que vem ganhando crescente aceitação em inúmeras áreas do conhecimento. É uma categoria de pesquisa cujo objeto é uma unidade que é analisada profundamente através de diversas técnicas. Pode ser caracterizado como um estudo de uma entidade bem definida, como um programa, uma instituição, um sistema educativo, uma pessoa ou uma unidade social. Visa conhecer o seu "como" e os seus "porquês", evidenciando a sua unidade e identidade próprias. É uma investigação que se assume como sendo "particularística", debruçando-se sobre uma situação específica, procurando descobrir o que há nela de mais essencial e característico. É um estudo formado por eventos atuais, além de não requerer controle sobre eventos comportamentais (CRESWELL, 2003).

Yin (2001) enfatiza que o estudo de caso é um método empírico de pesquisa que investiga um fenômeno contemporâneo dentro de seu contexto de vida real, especialmente quando as fronteiras entre o fenômeno e o contexto não são claramente evidentes. O estudo baseia-se em múltiplas fontes de evidência, que convergem numa triangulação, permitindo conclusões mais confiáveis. Também salienta que, em oposição a estratégias como grounded theory, o estudo de caso utiliza proposições teóricas e princípios conceituais na estruturação de formas de coletar, observar e classificar as informações obtidas. 
Como componentes da estrutura de um estudo de caso, destacam-se (Yin, 2001):

- Questões do estudo do tipo como? e/ou por quê?

- Proposições orientadoras do estudo, enunciadas a partir de questões secundárias;

- Definição de unidade de análise, podendo ser indivíduo, organização, setor, entre outras;

- Lógica que ligará os dados às proposições do estudo;

- Critérios para interpretar os achados - referencial teórico e categorias.

Yin (2001:56) sugere a adoção de critérios para avaliar a qualidade do desenho conceitual do estudo de caso. São eles: i) validade dos conceitos - medidas operacionais corretas para os conceitos que estão sob estudo; ii) validade interna (não utilizada para estudos exploratórios) para estabelecer uma relação causal, por meio da qual são mostradas certas condições que levem a outras condições, como diferenciada de relações espúrias; iii) validade externa - domínio ao qual as descobertas de um estudo podem ser generalizadas; iv) confiabilidade da pesquisa - demonstrar que as operações de um estudo, como os procedimentos de coleta de dados, podem ser repetidas, apresentando os mesmos resultados.

Uma crítica freqüente ao estudo de caso é feita por autores que consideram questionável a capacidade de generalização científica dos estudos de caso por se tratar de pesquisa qualitativa. Yin (1994) refuta esta colocação, lembrando que estudos de caso são, tal qual experimentos, generalizáveis para proposições teóricas e não para populações e universos. Isto significa dizer que o estudo de caso permite a generalização analítica. Não se deve confundir "generalização analítica" própria do Estudo de Caso - com "generalização estatística". O que se generaliza, no Estudo de Caso, são os aspectos do "modelo teórico encontrado". O caso não é um elemento amostral. Esta capacidade tem sido comprovada através da adoção de múltiplos estudos de caso e da lógica de replicação análoga a de múltiplos experimentos. 
A escolha de múltiplos estudos, ou seja, quando o estudo analisa mais de uma unidade específica com profundidade, sobretudo quando se trata de fenômenos em situações e contextos diferenciados, contribui significativamente para gerar princípios teóricos ou conceitos de análise inovadores.

Com base no que foi apresentado, o método de procedimento adotado, por ser considerado mais apropriado à natureza e aos objetivos desta pesquisa foi o estudo de multicasos. As unidades de análise determinadas são os arranjos produtivos locais de software de Belo Horizonte-MG, Blumenau-SC e Campinas-SP, com foco nas redes de conhecimento em melhoria de processos de software e qualidade localizadas. As questões orientadoras e as proposições da pesquisa encontram-se no primeiro capítulo desta tese e sustentaram os objetivos da pesquisa. Os critérios para interpretar os achados estão baseados no referencial teórico sobre aglomeração de empresas, redes de cooperação, geração e difusão do conhecimento e aprendizado. Os dados serão apresentados por categorias de análise, tendo em vista os objetivos traçados no primeiro capítulo.

Tendo como referência os critérios propostos por Yin (2001) para avaliar a qualidade do desenho conceitual, buscou-se garantir a validade dos conceitos estudados por meio de: uso de múltiplas fontes de evidência (entrevistas de diferentes partes envolvidas, com empresários e agentes de governança, empresários; coleta de informações factuais em documentos oficiais de programas de melhoria de processos de software, relatórios e documentos de entidades organizadoras de grupo de empresas, documentos e sites de comunidades de prática; observação direta $^{9}$ em atividades de troca de conhecimentos entre empresas; em eventos exclusivos para Instituições Organizadoras de Grupos de Empresas; consultas à documentos gerados por agentes de governança; consultas à páginas da internet; conversas informais com pessoas-chave nos arranjos produtivos e empresários do setor de software.

A validade interna não foi uma prioridade para este estudo, por se tratar de uma pesquisa exploratória. Ainda assim, quando se propôs alguma explicação,

\footnotetext{
${ }^{9}$ Observação do local escolhido para o estudo de caso; podem variar de atividades formais a atividades informais.
} 
tomou-se o cuidado de baseá-la em dados analisados em mais de um caso, que permitissem visualizar um padrão de comportamento.

Com relação à validade externa, (ou seja, a capacidade de generalização da pesquisa), esta foi garantida, ao menos parcialmente, pela abordagem de múltiplos estudos de caso, ainda que isto seja contestado por alguns autores (MILES e HUBERMAN, 1994).

Procurou-se garantir a confiabilidade da pesquisa, primeiramente, utilizandose um critério único para seleção das fontes pesquisadas em todos os estudos (acesso aos entrevistados-chave nos APL's de software - principais entidades de apoio local). Também buscou-se registrar as etapas de procedimentos de coleta de dados, que podem ser repetidas, no caso de verificação do estudo. As observações e os dados documentais foram anotados em caderno de campo e as informações foram analisadas a partir do cruzamento desses dados com os resultados das gravações das entrevistas.

\subsection{Procedimentos de coleta de dados}

Segundo Oliveira (1999), antes do início de qualquer pesquisa de campo, o primeiro passo é a análise minuciosa de todas as fontes documentais, que sirvam de suporte à investigação projetada. Portanto, pode-se concluir que os procedimentos de coleta de dados incluem a pesquisa bibliográfica e de fontes documentais como também a pesquisa de campo.

A primeira etapa para a elaboração do estudo constituiu-se na pesquisa bibliográfica de fontes secundárias, que são as principais bibliografias já tornadas públicas em relação ao tema de estudo (aglomerações produtivas, redes de cooperação, geração e difusão do conhecimento e processos de aprendizado): desde publicações avulsas bem como boletins, jornais, revistas, livros, artigos, monografias, dissertações, teses, e outros. 
O trabalho de campo analisou como ocorreu a dinâmica de aprendizagem das PME's de software em ambientes de interação (ou redes de conhecimento e aprendizagem). Desta forma foi possível identificar como as empresas se relacionam com as principais fontes externas de conhecimento local (APL's), como é a difusão do conhecimento no interior dessas redes, como a governança local e os aspectos institucionais influenciam os processos de aprendizado, geração e difusão do conhecimento. As técnicas de coleta de dados utilizadas para obterem essas informações no trabalho de campo foram:

Dois roteiros de entrevista semi-estruturados (apêndice I e II): um voltado às principais entidades de apoio ao setor de software e outro às empresas participantes das redes de conhecimento identificadas nos APL's. O roteiro voltado aos principais agentes de governança do setor teve como objetivo identificar os esforços para a disseminação de conhecimentos e capacitação das empresas em melhoria de processos de software e qualidade e como a instituição apóia, promove ou oportuniza condições para facilitar o acessos destas empresas às ações desenvolvidas pela instituição. O roteiro voltado às empresas teve como foco principal conhecer como essas empresas aprendem e podem aprender conhecimentos em qualidade e melhoria de processos de software, uma necessidade bastante presente para estas empresas.

Outra técnica utilizada foi a observação direta em atividades de troca de conhecimento de empresas (Workshop de empresas que adotaram o programa MPS.BR). A observação é um instrumento fundamental na coleta dos dados, pois possibilita o contato estreito e pessoal do pesquisador com o fenômeno pesquisado e a descoberta de aspectos novos de um problema contribuindo para a investigação proposta e servindo para compreender melhor a realidade em estudo.

A pesquisadora participou de um Workshop fechado de Instituições Organizadoras de Grupos de Empresas (IOGES) onde foi discutido o Modelo de Negócio Cooperado de PME's para implementação do Programa MPS.BR. Nesta oportunidade foram discutidos, dentre vários assuntos, as estratégias de gestão e formas de aprendizagem utilizadas pelas instituições organizadoras em seus programas de negócio cooperado. 
Também fez parte do trabalho de campo, a análise documental. Esta é uma importante técnica de abordagem de dados qualitativos, que buscou identificar informações relativas às formas de aprendizagem e difusão do conhecimento das empresas no âmbito das redes analisadas.

Também foram consultados documentos gerados pela imprensa especializada, por entidades de apoio e classe (pesquisas e informações locais); consultas à websites do setor; conversas informais com pessoas-chave nos arranjos produtivos e empresários do setor de software.

Por fim, cabe destacar a contribuição de conversas informais e contatos que possibilitam uma melhor compreensão do fenômeno estudado.

O emprego das diversas técnicas de coleta dos dados permitiu realizar uma triangulação dos dados, e possibilitou um melhor entendimento do problema de pesquisa.

\subsection{Etapas da pesquisa de campo}

A pesquisa de campo foi realizada em duas etapas. A primeira, iniciou-se com um reconhecimento de campo, através da identificação dos principais agentes de governança do setor de software nos APL's, dentre estes, as principais entidades de apoio relacionadas à promoção do conhecimento e aprendizado em melhorias de processos de software e qualidade. As entidades identificadas e entrevistadas nos respectivos pólos foram 10:

- Campinas: Núcleo SOFTEX Campinas; CenPRA; CIATEC e UNICAMP

- Belo Horizonte: FUMSOFT (Agente SOFTEX); ASSESPRO; SEBRAE; SINDINFOR

- Blumenau: BLUSOFT; FURB 
O estudo foi realizado com um universo de 14 PME's. Sendo 6 empresas de Campinas, 5 empresas de Belo Horizonte e 3 de Blumenau

\section{Critério para classificação das PME’s estudadas:}

A especificação de qualquer padrão de definição de pequenas empresas é algo arbitrário, pois há padrões diferentes para propósitos diferentes. Existe uma infinidade de critérios para definição e classificação das pequenas empresas que podem ser entendidos como quantitativos, qualitativos ou ainda multicriteriais (PINHEIRO, 1996; JULIEN, 1997).

Os critérios quantitativos são mais utilizados que o segundo por serem de ordem econômica e/ou contábil e utilizam índices como: número de funcionários, faturamento, valor de imobilização de ativos, capital social, lucros, patrimônio líquido. Os índices são de mais fácil acesso para realizar a classificação. Os critérios quantitativos apresentam várias vantagens em adotá-los, pois permitem a determinação do porte da empresa; os índices são fáceis de serem coletados; permitem o emprego de medidas de tendência de tempo; possibilitam análises comparativas; são de uso corrente nos setores institucionais públicos e privados.

Os critérios qualitativos embora apresentem uma visão mais real do porte da empresa são mais complexos, pois analisam aspectos de cunho gerencial e social, tais como: organização e administração; especialização de cargos-chave; dificuldade na obtenção financeira; condição de participação e domínio do mercado em que atuam em termos de concorrência e competitividade, aquisição de insumos e matérias-primas, produtos comercializados; nível tecnológico; independência de grupos de empresas.

A combinação dos critérios quantitativos e qualitativos parece ser a mais coerente para se obter uma melhor classificação, em virtude de associar fatores econômicos e características sociais e políticas da empresa. Porém, este não será o critério a ser adotado no trabalho devido à dificuldade de se obter as informações necessárias para o desenvolvimento da classificação. 
Ainda que a indústria de software apresente peculiaridades que a diferenciem da indústria de manufatura, não foi identificado um critério padrão internacional para caracterizar as micro, pequenas e médias empresas deste setor.

Portanto, o critério adotado para a classificação das PME's no trabalho de campo foi o quantitativo combinado com o setor da empresa, uma vez que apresenta diversas vantagens já apontadas anteriormente (tabela 4.1) e é utilizado como praxe por instituições governamentais e privadas brasileiras, assim como por grande parte dos autores sobre o assunto.

\begin{tabular}{|c|c|c|}
\hline Classificação & $\begin{array}{c}\text { № de } \\
\text { Funcionários } \\
\text { (indústria) }\end{array}$ & $\begin{array}{c}\text { № de Funcionários } \\
\text { (comércio/serviços) }\end{array}$ \\
\hline micro & $0-19$ & $0-9$ \\
\hline pequena & $\mathbf{2 0 - 9 9}$ & $10-49$ \\
\hline média & $100-499$ & $50-99$ \\
\hline grande & acima de 500 & acima de 100 \\
\hline
\end{tabular}

Tabela 4.1: Critério utilizado para classificação das empresas Fonte: SEBRAE NACIONAL (1998) 


\section{A DINÂMICA DA APRENDIZAGEM EM APL'S DE SOFTWARE}

Este capítulo tem como objetivo principal apresentar a dinâmica da aprendizagem em melhoria de processos de software no interior dos pólos estudados. Para isto será apresentada primeiramente uma caracterização do arranjo com enfoque nas suas origens e desenvolvimento e estrutura de governança local. Posteriormente, serão descritas as principais fontes externas de conhecimento em melhoria de processos de software e as interações das empresas com agentes locais. Por fim, como variáveis principais desta tese, serão analisados e comparados os processos de aprendizagem e difusão do conhecimento no âmbito das redes de conhecimento identificadas. Vale destacar que o capítulo apresentará, primeiramente, uma descrição dos dados e, posteriormente, uma análise crítica e comparativa considerando os principais aspectos relacionados ao objetivo desta tese.

\subsection{Origem e desenvolvimento do APL de Campinas}

A região de Campinas pode ser considerada um grande centro tecnológico em diversas áreas do conhecimento. Possui grande expressão no cenário econômico estadual e mesmo nacional, em virtude de apresentar importantes requisitos (infra-estrutura educacional, laboratórios, centros de pesquisa e tecnologia, mão-de-obra qualificada, facilidades de logística, entre outros) para o desenvolvimento de atividades intensivas em alta tecnologia.

A região sudeste do estado de São Paulo, na qual está inserida a cidade de Campinas, tem a maior concentração nacional de atividades de desenvolvimento de software e serviços, assim como o maior contingente de pessoas ocupadas nesta atividade (RAIS/ MTE 2003). 
Apesar da relevante importância da região, não foi possível encontrar pesquisas que apresentem dados mais concretos da configuração produtiva local de software, pelo fato da região possuir uma estrutura industrial bastante diversificada. De modo que os dados disponíveis sobre software nesta região estão sempre vinculados ao universo das atividades de Tecnologia da Informação e Comunicação. Espera-se que com o mapeamento da indústria nacional de software a ser realizado pela SOFTEX e IBGE, esta carência seja suprida.

As origens históricas da atual estrutura produtiva de Campinas estão relacionadas à implantação e trajetórias das grandes empresas do setor que se instalaram pioneiramente na região atuando principalmente em setores de telecomunicações, informática, microeletrônica, entre outros setores intensivos em tecnologia, como também de um grande número de empresas de pequeno e médio porte fornecedoras de insumos, componentes, peças e serviços. Estas empresas foram particularmente atraídas pela presença de uma forte estrutura educacional, institutos de pesquisa científica e tecnológica, organismos de apoio às atividades de ciência e tecnologia, infra-estrutura de transporte ${ }^{11}$ pessoal qualificado, entre outros. Destaca-se, também a presença de uma base tecnológica local que favoreceu a troca de conhecimentos, sobretudo tácitos, reforçada pela concentração geográfica de produtores.

Neste contexto, empresas pioneiras, como a IBM, a HP, entre outras, trouxeram importantes implicações para o pólo na medida em que incentivaram a criação de capacidades locais, através do desenvolvimento de uma rede de fornecedores e prestadores de serviços das empresas líderes, muitas delas pequenas e médias empresas. Também fomentaram um processo de aprendizado local, através da formação de um contingente de trabalhadores especializados, com habilidades tácitas específicas que foram se incorporando aos agentes locais. $\mathrm{Na}$ medida em que esses trabalhadores (detentores de conhecimentos especializados) trocavam seus empregos por outras empresas locais ou montavam seus próprios negócios, tornaram-se um importante mecanismo de transmissão do conhecimento

\footnotetext{
${ }^{11}$ O pólo de Campinas possui uma infra-estrutura de transporte, que inclui importantes rodovias (Santos Dumont, Bandeirantes, Dom Pedro I, Anhanguera, Campinas - Mogi-Mirim), que facilita o escoamento da produção local para os principais centros consumidores do Brasil e do exterior.
} 
tácito no pólo. Com isso, o aprendizado coletivo e a capacidade inovativa da região foram intensificados (SOUZA e GARCIA, 1998).

O estabelecimento do CPqD - Centro de Pesquisa e Desenvolvimento da Telebrás na região em 1980, também foi fundamental para atrair novas empresas e fomentar a capacidade inovativa do pólo. Muitas empresas, principalmente multinacionais fixaram-se estrategicamente próximas ao $\mathrm{CPqD}$, para procurar atender às exigências da política estatal para o setor de telecomunicações da época, quanto ao grau de nacionalização das tecnologias utilizadas pelos fornecedores de equipamentos e à política de compras. Com isto, o centro determinava os padrões tecnológicos a serem adotados pelas empresas e influenciava a dinâmica tecnológica do pólo. O CPqD contribuiu também para desenvolver localmente os principais avanços da indústria nacional de telecomunicações, como as centrais digitais trópico e a produção pioneira de fibras óticas no país (SUZIGAN et. al. 2001).

Uma das influências importantes do CPqD na difusão de conhecimentos locais foi a sua extensiva participação na comunidade científica e tecnológica, do Brasil e exterior, através de acordos e convênios em pesquisa e desenvolvimento, que resultaram em constantes intercâmbios de conhecimentos com as universidades. Isto serviu para fomentar um importante processo local de geração de inovações que representou um grande ganho de competitividade à indústria brasileira (SOUZA e GARCIA, 1998).

A UNICAMP - Universidade Estadual de Campinas, instalada em 1966, foi uma das grandes influências na origem e consolidação do pólo de Campinas, pela sua forte ênfase em pesquisas de caráter tecnológico e pela formação abundante de recursos humanos altamente qualificados. A universidade conta com uma estrutura de diversos institutos, faculdades, laboratórios voltados para as áreas de física e engenharia. "Aliás, boa parte do contingente atual de pequenos e médios empresários de software na atualidade é proveniente do tradicional Curso de Engenharia Elétrica da UNICAMP ${ }^{12 "}$.

\footnotetext{
${ }^{12}$ Dados informais obtidos em entrevista no Núcleo SOFTEX CAMPINAS na pesquisa de campo.
} 
O CPqD e a UNICAMP juntos atuaram como dois importantes centros difusores de efeitos spillovers (transbordamentos de conhecimentos) e indutores da atração e formação de novas empresas.

Outras instituições de ensino superior, como a PUC - Pontifícia Universidade Católica de Campinas (instituição com mais de 60 anos de existência) e de ensino técnico orientado, também desempenharam e ainda desempenham importante papel na formação de profissionais e mão-de-obra qualificada local.

Dentre as instituições de apoio e suporte que contribuíram para a consolidação do pólo e ainda contribuem, destaca-se o Centro Tecnológico para Informática (atual CenPRA - Centro de Pesquisas Renato Archer, órgão do Ministério da Ciência e Tecnologia). A instituição tem mais de 25 anos de existência e experiência em desenvolvimento e implementação de pesquisas científicas e tecnológicas no setor de informática. Foi muito importante na criação de capacidades locais e na atração de novas empresas. É ainda uma importante referência local e nacional em difusão de conhecimento tecnológico em fornecimento de soluções integradas para a inovação de produtos e processos de alto conteúdo tecnológico.

Uma das forças políticas locais, criada em 1991, com o objetivo de coordenar ações entre empresas, de modo a estimular a implantação de empresas de base tecnológica da cidade, e de intermediar as relações entre as empresas e a universidade e os institutos de pesquisa, foi a CIATEC - Companhia de Desenvolvimento do Pólo de Alta Tecnologia de Campinas. A instituição foi importante para a criação de dois parques tecnológicos que somam juntos oito milhões de metros quadrados. Os parques abrigam muitas firmas subsidiárias de empresas que estão entre as maiores do mundo. A criação desta instituição foi importante para demonstrar aos possíveis entrantes a existência de um comprometimento do governo local com as atividades de fomento do pólo. Entretanto, a instituição parece não ter conseguido desempenhar plenamente suas funções de articulação das relações entre as empresas e demais instituições tecnológicas (PORTO et al, 2000). 
Com a consolidação do pólo, outras instituições instalaram-se no local, tais como o Núcleo Regional e a Coordenação Nacional do SOFTEX e o IEE - Instituto de Estudos Econômicos em Software com a finalidade de prestar suporte às empresas locais, sobretudo, pequenas e médias.

Os anos 90 foram marcados pela forte redução do papel do Estado na economia nacional através da implantação de políticas de liberação das importações, objetivando uma maior integração da economia brasileira na economia internacional. Na Indústria de Informática, a reserva de mercado foi abandonada em 1992 e substituída por uma política mais orientada à livre concorrência. Neste período houve uma onda de investimentos e a entrada de novas e grandes empresas multinacionais (Ericsson, Motorola, Lucent, e outras) que se fixaram na região de Campinas, atraídas pelas perspectivas de crescimento do mercado doméstico em telefonia.

O pólo passou por fortes modificações com a entrada de grandes empresas multinacionais de tele-equipamentos. Muitas empresas nacionais desapareceram e as instituições locais redefiniram seus papéis, a exemplo do CPqD que se tornou uma fundação. As atividades tecnológicas permaneceram, graças, em parte, à Lei de Informática que proporcionou a manutenção dessas atividades. Entretanto, esse instrumento não foi o bastante para criar, ou recriar, um ambiente de interações tecnológicas mais intensas no local (DIEGUES e ROSELINO, 2006).

A atual configuração da atividade produtiva é essencialmente formada por dois grupos de empresas: i) empresas nacionais, em sua maioria, de pequeno e médio porte (software houses), tipicamente originadas de instituições locais como a UNICAMP, o CPqD. O estudo de Diegues e Roselino (2006) identificou a atuação das software houses em segmentos bastante diversificados, com concentração no desenvolvimento de software customizado e de serviço de alto valor. Esta pesquisa apesar de qualitativa, envolvendo um universo bem mais restrito de empresas (8 firmas), também identificou essas características na "amostra" das empresas entrevistadas; ii) empresas multinacionais, de grande porte, que concentram sua 
atenção no setor de equipamentos para telecomunicações e estabelecem algumas parcerias tecnológicas com institutos de P\&D locais.

A formação e a consolidação do pólo de atividades de $\mathrm{TI}$ da região de Campinas estão estreitamente relacionadas à rede de instituições de ensino e pesquisa, aos centros de P\&D e aos laboratórios estabelecidos localmente que contribuíram para a criação e difusão de conhecimentos científicos e tecnológicos. A mobilidade de mão-de-obra local, a formação de profissionais qualificados, as interações das instituições de pesquisa com o setor produtivo e a criação de novas empresas contribuíram para culminar num processo cumulativo de aprendizado coletivo, que gerou capacitações específicas e dinamizou a capacidade de inovação das empresas locais (SUZIGAN et. al, 2005).

Entretanto, nos últimos anos, as interações locais diminuíram quantitativamente e a natureza das relações também mudou. As empresas estão mais preocupadas em ações coletivas que tragam ganhos comerciais do que aprendizado inovativo.

\subsubsection{Agentes de Coordenação Local e suas funções}

Com relação a este assunto é importante enfatizar que este estudo esteve mais preocupado em identificar os principais agentes de coordenação local que contribuem, direta ou indiretamente, para a promoção de interações e cooperações voltadas ao conhecimento e aprendizado das PME's em melhoria de processos de software e qualidade. Entretanto, como conseqüência natural de um trabalho de pesquisa exploratório, também foi possível constatar a influência de agentes em outros assuntos de interesses coletivos do setor, que serão aqui mencionados.

Assim, as principais instituições de coordenação local voltadas aos interesses das empresas em melhoria de processos de software e qualidade são duas: 
1. O SOFTEX Campinas que é uma entidade que congrega empresas de $\mathrm{TI}$ e foi fundada em 1993. Tem como missão e foco atuar como catalisador no processo de desenvolvimento das empresas de software, realizando ações demandadas pelas empresas e das quais estas empresas participem ativamente. A instituição está organizada em seis verticais operacionais:

- Empreendedorismo: tem por objetivo fomentar a criação de novas empresas de software fornecendo condições para que estas amadureçam e se consolidem como empresas competitivas no setor onde atuam. Os principais diferenciais nesta área são: o acompanhamento compulsório do desempenho das empresas incubadas nas áreas de gestão empresarial e mercado, e a capacidade de incubação de spin-offs de grandes empresas.

- Capacitação: tem como objetivo prover as necessidades das empresas associadas e incubadas através de cursos, workshops, palestras, conceitos e palestras essenciais à gestão do negócio e das pessoas; qualidade e melhoria dos processos produtivos; desenvolvimento de novas tecnologias e técnicas de produção e de controle dos processos.

- Exportação: tem como objetivo prospectar mercados e fomentar a exportação e a inserção das empresas em mercados internacionais. O núcleo ajudou a coordenar as ações de um grupo de 10 (dez) empresas associadas na formação de um consórcio de exportação.

- Financiamento: atua junto às empresas auxiliando na elaboração de projetos destinados a captação de recursos de financiamento e de fomento. A instituição opera junto aos fundos de investimento aproximando-os das empresas incubadas e associadas e também atua apoiando essas empresas através de consultorias técnicas, na elaboração de planos de negócios.

- Excelência: teve início no ano de 2007. Busca estabelecer novos paradigmas junto às empresas, tais como, gestão corporativa responsável, gestão do conhecimento, ética nos negócios, responsabilidade social e outros assuntos que sirvam como diferencial competitivo das empresas. No início de 2007, o SOFTEX 
Campinas em parceria com as empresas de software e TI da região deu início a um projeto de geração de mão-de-obra chamado "Descobrindo Talentos". O objetivo do programa é formar mão-de-obra de acordo com as necessidades das empresas participantes. Além disso, também possui caráter de "inclusão social”, pois participam do projeto apenas alunos das escolas e faculdades que não são consideradas de "ponta". Os alunos devem estar no $3^{\circ}$ ou $4^{\circ}$ ano de cursos como Engenharia Elétrica, Ciência da Computação, Processamento de Dados e outros da área de $\mathrm{TI}$, ou no penúltimo ano do curso técnico. São selecionados por representantes da área de recursos humanos das empresas envolvidas. Passam 6 (seis) meses recebendo aulas com ementas definidas pelas empresas. O projeto oferece toda a infra-estrutura de ensino e as aulas ocorrem no período noturno e aos sábados. Cada aluno é apadrinhado por uma empresa e no final de cada rodada do projeto esses alunos são absorvidos pelas empresas. No $1^{\circ}$ semestre de 2007 foram capacitados 18 alunos, no $2^{\circ}$ semestre 64. Para $01^{\circ}$ semestre de 2008 são aproximadamente 120 alunos.

- Qualidade: É uma das vertentes mais importantes. Seu principal objetivo é a implantação de metodologias de controle de processo e qualidade de software baseadas em padrões internacionais como CMMI, ISO 15504 (SPICE) e principalmente MPS.BR. Através de recursos de órgãos de fomento (BID e SEBRAE) e da operação cooperada, os custos da implantação das metodologias são bastante reduzidos em relação aos custos de mercado. Até o final de 2007, a instituição havia organizado 3 grupos cooperados de PME's para a implementação e avaliação do Modelo MPS.BR. Os grupos envolveram 20 (vinte) empresas, sendo que deste total, 8 (oito) delas concluíram as atividades e foram aprovadas nas Avaliações Oficiais a que se submeteram (Nível G e F do Modelo MPS.BR). Quatro (4) empresas estiveram em processo de avaliação oficial até janeiro de 2008 e 8 (oito) empresas estão em processo de implantação da metodologia. Foram selecionadas 13 (treze) empresas que estão aguardando publicação de um novo Comunicado de Apoio a Formação de Grupos de Empresas. Dentre as IOGES (Instituições Organizadoras de Grupos de Empresas) presentes no Brasil (até novembro de 2007 eram 11 IOGES no total), o Núcleo SOFTEX Campinas tem destacado desempenho na formação de grupos cooperados de pequenas empresas. Entretanto, chama a atenção o fato de que apenas 6 empresas, num universo de 34 
(considerando o terceiro grupo que está aguardando para iniciar o programa), são de Campinas. A maioria das empresas participantes do modelo cooperado está localizada na região de Ribeirão Preto -SP, onde também parece haver concentração de empresas de software.

2. CenPra - Centro de Pesquisas Renato Archer, órgão do Ministério da Ciência e Tecnologia é um dos maiores centros de empresas de telecomunicações e informática do país e um dos principais pólos científicos e tecnológicos da América Latina. Congrega competências na qualificação de produtos e processos da Tecnologia da Informação, engenharia de protótipos e produtos, projetos especiais de pesquisa e desenvolvimento, informatização de sistemas sócio-econômicos, meio-ambiente, infra-estrutura e aplicações na Internet. Tem reputação destacada no credenciamento de instituições e laboratórios em todo o país em avaliação da qualidade de produtos e processos de software e outras atividades em engenharia, informatização de sistemas e desenvolvimento tecnológico de processos de software.

O Centro mantém ações de cooperação internacional com diversas instituições de pesquisa e participa, na qualidade de membro, em comitês de organismos de normalização nacionais e internacionais, como ABNT e ISO International Organization for Standardization e IEC - International Electrotechnical Comission. Ainda no cenário mundial, o CenPRA mantém liderança dentro do Programa Ibero-americano de Ciência e Tecnologia para o Desenvolvimento (CYTED), que é integrado por 21 países de origem ibero-americana e tem como objetivo fomentar a cooperação em pesquisa aplicada no setor tecnológico.

Possui uma divisão específica de Melhoria de Processos de Software, que tem como objetivos o acompanhamento, a pesquisa e o desenvolvimento tecnológico na área de processos de software visando à elaboração de métodos para avaliação e melhoria.

Apesar de ser essencialmente um centro de pesquisa governamental, as suas ações se expandem para o segmento acadêmico e empresarial. Oferece consultorias e treinamentos em diversas áreas, dentre elas, qualidade de software, 
avaliação e melhoria de processos com CMM/CMMI e ISO/IEC 15504 (SPICE), engenharia de protótipos e produtos de TI, sistemas sócio-econômicos, de meio ambiente e infra-estrutura. Também atua em serviços de análise e qualificação de processos e produtos (hardware e software), especialmente para pequenas e médias empresas.

O Cenpra juntamente com alguns parceiros promove anualmente, desde 1999, um Simpósio Internacional de Melhoria de Processos de Software SIMPROS. O objetivo é disseminar as principais tendências para melhoria de processo de software no cenário nacional e internacional. A idéia é que o evento seja um fórum de intercâmbio de informações, troca de experiências práticas, conhecimento e aprimoramento da capacitação gerencial e técnica das empresas na área de melhoria de processo e qualidade de software. O simpósio é voltado para profissionais, empresários, professores, estudantes, pesquisadores e interessados em melhoria de processo de software.

3. Algumas instituições de ensino e pesquisa do arranjo também exercem influência na promoção de interações no arranjo. A UNICAMP foi apontada na pesquisa como a principal delas, sendo responsável pela formação e elevada qualificação da mão-de-obra local. Fundada em 1966, a instituição disponibiliza em torno de 225 cursos (graduação, pós-graduação e extensão). Os cursos de Engenharia Elétrica e Engenharia da Computação são responsáveis pelas principais interações com outros agentes do pólo. Esses cursos possuem qualificados recursos computacionais e laboratoriais que podem ser utilizados em pesquisas básicas na área de TI. A instituição também promove a interação e aprendizado através de projetos de pré-incubação de empresas de base tecnológica, cursos de empreendedorismo e inovação, parcerias e suporte em projetos desenvolvidos pelo SOFTEX Campinas.

4. A PUCCAMP e a Universidade São Francisco também possuem destaque na formação de mão-de-obra qualificada do arranjo, principalmente de software. Ambas instituições possuem cursos de graduação e pós-graduação voltados à área de TI com alto índice de ocupação de alunos provenientes de empresas do setor na região. 
5. Como tratam de outros assuntos de interesse do setor como exportação e importação, também destacam-se duas entidades, a SECOOP - Secretaria de Cooperação Internacional e o Trade Point Campinas Viracopos. A SECOOP atua intermediando interesses da cidade e seus setores produtivos no exterior. Firma protocolos com "cidades irmãs" (instrumento de reciprocidade global que permite, entre outras coisas, que os exportadores e importadores do pólo de Campinas tenham algumas facilidades). Também realiza seminários onde são enfocados mercados potenciais para negócios em cidades e regiões ao redor do mundo. $O$ Trade Point Campinas Viracopos é uma organização sem fins lucrativos que tem como função básica auxiliar as empresas a encontrarem compradores estrangeiros para seus produtos, ou mesmo, fornecedores às importações. Assim como seus congêneres ao redor do mundo, o Trade Point integra um programa global da Organização das Nações Unidas - ONU.

6. A CIATEC, como já mencionado anteriormente, é uma instituição pública que foi concebida para articular as relações entre empresas, universidades e institutos de pesquisa científica e tecnológica. Entretanto, sua atuação está limitada a coordenar a instalação de empresas nos Parques Tecnológicos e a gerir um programa local de incubadora de empresas de alta tecnologia. Suas ações têm menor visibilidade comparada à SOFTEX e a SECOOP.

Apesar da presença de várias instituições de ensino e pesquisa, o que se pode notar através da pesquisa é que ainda falta uma política local consistente para promover uma coordenação maior e melhor entre os agentes de governança do setor. Foi apontado na pesquisa com as entidades locais que a interação ou cooperação entre os agentes para viabilizar ações conjuntas locais é (de modo geral) bastante dificultosa.

No âmbito da estrutura educacional técnica ou orientada (profissionalizante), a região de Campinas possui 2 importantes unidades de ensino que articulam-se com o setor.

O COTUCA - Colégio Técnico de Campinas, é uma unidade de Ensino Médio e Técnico da UNICAMP, que iniciou suas atividades em 1967. A Escola possui 14 
cursos técnicos e 3 especializações de nível técnico, além cursos de extensão e parcerias. Os cursos técnicos podem ser concomitantes ao ensino médio ou seqüenciais (para alunos com o Ensino Médio já completo). Os alunos de maior interesse pela comunidade empresarial do setor de TI são provenientes dos cursos técnicos de Eletroeletrônica e Informática e Telecomunicações. O COTUCA conta com mais de 300 empresas conveniadas, para encaminhamento de estagiários e realização de parcerias.

O ETEC - Ensino Técnico de Campinas do grupo Escola Salesiana São José e UNISAL - Centro Universitário Salesiano oferece cursos de Mecatrônica, Informática, Informática Industrial, Processamento de Dados, Telecomunicações e outras cursos de outras áreas. A escola possui muitas parcerias firmadas com empresas de grande porte do setor de TI na cidade.

\subsubsection{Interações e Processos de aprendizado no APL de Campinas}

Como já mencionado anteriormente no capítulo 2 desta tese, o acúmulo de conhecimentos, que permite o desenvolvimento de capacitações específicas às firmas, está relacionado aos processos dinâmicos de aprendizado empreendidos pelas mesmas. Tais processos podem estar baseados na interação com fontes internas ou externas de conhecimento.

Este tópico tem como objetivo apresentar as formas de interação e aprendizado das PME's de software do pólo de Campinas com fontes externas de conhecimento (interações e cooperações com concorrentes, clientes, organismos de apoio, universidades e centros de pesquisa e capacitação) dada a importância crítica deste tipo de aprendizado para a capacidade de inovar das empresas. É óbvio que o aprendizado interno tem sua devida importância, inclusive para dar condições à empresa de receber e incorporar o aprendizado externo. Embora este não seja o foco principal da pesquisa, ele também foi mencionado no estudo de campo realizado e deverá ser referido como possível forma de conhecimento. 
Foi possível identificar na pesquisa 5 tipos básicos de interação das PME's com fontes externas com objetivos de melhorar ou desenvolver novos processos de software (com objetivos de certificação ou não). Algumas delas mais e outras menos proeminentes, e que serão analisadas posteriormente no estudo comparativo.

\section{- Interação com instituições de ensino locais}

As empresas pesquisadas produzem software sob encomenda e software customizado. O principal mercado das empresas é nacional. O número de profissionais com nível de escolaridade formal superior nas empresas é bastante elevado. Todas elas disseram possuir conhecimentos sobre metodologias de melhoria de processos. Uma delas disse não ter necessidade de documentar seus processos e procedimentos, dado o porte reduzido da empresa, mas disse ter seus processos controlados. Algumas empresas pretendem implementar metodologias de melhorias, mas não no momento, por não disporem de recursos financeiros e tempo de trabalho de seus colaboradores para projetos desta natureza, além de existirem outros projetos que exigem investimentos e prioridades. Uma das empresas já implementou o MPS.BR, mas a cultura da empresa não absorveu plenamente as mudanças.

A interação com instituições de ensino locais foi apontada por todas as empresas que participaram da pesquisa. As empresas interagem principalmente com as instituições de ensino superior (UNICAMP, PUCCAMP e outras), com o objetivo de contratar profissionais já qualificados, ou eventualmente para troca de informações informais a respeito de melhores práticas com pessoas já da rede de relacionamentos das empresas. As empresas preocupam-se em atrair pessoas qualificadas porque acreditam que com a base conceitual recebida das boas escolas, elas já podem obter um diferencial em relação a seus concorrentes. As empresas também afirmaram que os trabalhos de final de curso, cursos de pósgraduação e extensão também são fontes de conhecimento que geram aprendizado. Os alunos realizam seus trabalhos nas empresas, trocam experiências e informações e multiplicam o conhecimento adquirido entre os colaboradores. Alunos com graduação, especialização e uma boa experiência são os principais alvos das empresas. Buscar o profissional na universidade e formá-lo na empresa é uma forte 
característica de aprendizado e desenvolvimento de capacitações das empresas. O trabalho das incubadoras também contribui para que as empresas estabeleçam relações com o meio acadêmico e a pesquisa possibilitando que os produtos sejam já de início desenvolvidos de forma melhor.

\section{- Interação produtor-clientes}

A interação com clientes também é percebida como uma importante fonte de conhecimento e aprendizado para as empresas de software aperfeiçoarem produtos e processos, principalmente para o segmento produtivo de produtos customizados e sob encomenda onde a transferência de conhecimento tácito é bastante presente.

\section{- Interação com outras empresas de software do pólo (inclusive concorrentes)}

A pesquisa também sinalizou a existência de processos de interação com algum fluxo de informação e conhecimento entre as empresas. Muitos pequenos e médios empresários do setor são egressos das instituições de ensino locais e possuem uma rede de relacionamentos restrita e que está historicamente circunscrita. Devido a isto, os empresários destacaram a confiança como elemento básico para a troca de informações. Alguns deles costumam se encontrar semanalmente em ambientes informais para a troca de informações. A falta de um agente articulador que fomente a cooperação entre as empresas foi bastante enfatizada. As empresas também apontaram as feiras e eventos como fontes de informações utilizadas para diversas áreas, inclusive sobre práticas relacionadas à melhoria de processos e produtos de software. A pesquisa também identificou, com menor expressividade a existência de Comunidade de Prática para discussão de temas relacionados à melhoria de processos de software.

\section{- Interação com centros de pesquisa}

Foi também registrada na pesquisa a interação com serviços laboratoriais de Centros de Pesquisa, especificamente o CenPRA para avaliação de qualidade de 
produto de acordo com requisitos da norma ISO/IEC 14598-5. Entretanto foi destacada a necessidade de maior atuação da instituição junto ao segmento empresarial.

\section{- Interação e Cooperação com instituições e programas de apoio}

Foi verificada através da pesquisa uma ação de cooperação com o SOFTEX Campinas para implementação do Modelo MPS.BR .

As fontes de informação consideradas mais relevantes para o aprendizado das empresas em melhoria e qualidade de processos de software foram a área de produção da empresa, a área de pesquisa e desenvolvimento e análise crítica dos sucessos e fracassos de operações e projetos internos. Isto significa que as informações geradas internamente e o conhecimento compartilhado na empresa são muito importantes para o conhecimento e capacitação das empresas de software (learning by using, learning by doing).

A Internet, as feiras, conferências e exposições e encontros informais de lazer foram considerados importantes fontes de conhecimento externo. Este último bastante relacionado à questão da territorialidade, onde questões como proximidade cultural e confiança são muito importantes.

Segundo as empresas, as instituições locais de apoio (associações empresariais) poderiam contribuir mais efetivamente para fomentar o aprendizado coletivo voltado à melhoria e qualidade de processos diagnosticando melhor as necessidades das empresas e direcionando forças para atender estas necessidades.

\subsection{Origem e desenvolvimento do APL de Belo Horizonte}

Os primeiros empreendimentos empresariais em software e atividades de informática em Belo Horizonte tem suas origens no contexto dos birôs de serviços 
que através de mainframes ${ }^{13}$ prestavam serviços de processamento de dados para grandes companhias, como CEMIG - Companhia Energética de Minas, Mannesman e Belgo Mineira que instalaram-se na cidade nas décadas de 50 e 60. Na época, a ELETRODADOS, Empresa do Grupo Mercantil do Brasil, foi a principal referência no local, vendendo serviços de processamento de dados para terceiros ou cedendo seu espaço para a utilização das empresas.

Outros fatores importantes na trajetória de desenvolvimento do pólo de $\mathrm{BH}$ foram as atividades em computação na UFMG - Universidade Federal de Minas Gerais no final da década de 60 desenvolvidas pelo Centro de Computação CECOM. O curso foi um dos primeiros no Brasil e importante referência até os dias de hoje na formação de mão de obra qualificada e pesquisa que contribui para a disseminação do conhecimento e criação de empresas locais.

Nos últimos anos, o setor de software é o segundo com maior crescimento no número de empregos. São estimados mais de 15 mil postos de trabalho no setor (dados da Prefeitura de BH baseado na RAIS/MTE - Relação anual de informações Sociais do Ministério do Trabalho e Emprego de 2004).

Dados de 2006 (SEBRAE, 2006) apontam para a presença de 2.800 empresas ligadas ao setor de software em Belo Horizonte. São mais de 1.300 empresas desenvolvedoras de software, sendo que o restante comercializa software ou hardware. O perfil das empresas é predominantemente de micro e pequeno porte. No desenvolvimento de software, produção sistemas, produtos e soluções, as atividades são bastante pulverizadas (comércio, educação, gestão, telecomunicações, software de serviços bancários, financeiros, turismo, entre outros). Os principais clientes, da maioria, são locais ou dentro do Estado mineiro.

As empresas desenvolvedoras de software vêm apresentando sustentabilidade ao longo dos últimos anos. Em 2005, essas empresas faturaram mais de $R \$ 1$ bilhão de reais. As prospecções de crescimento para o setor nos próximos anos são positivas (SEBRAE, 2006).

\footnotetext{
${ }^{13}$ computadores de grande porte dedicado normalmente ao processamento de um grande volume de informações.
} 
Na região metropolitana de Belo Horizonte, há 24 cursos de graduação com aproximadamente 3000 vagas (em Sistemas de Informação, Ciência da Computação, Análise de Sistemas, Ciência da Computação com ênfase em Sistemas de Informação e Engenharia da Computação). Os cursos tecnológicos geram aproximadamente 2700 vagas distribuídas em 11 cursos.

As empresas possuem boa competência técnica mas muitas dificuldades gerenciais (fato comum nas micro e pequenas empresas). Uma das principais carências do setor é competência comercial para penetrar em outros estados e também no mercado internacional. As empresas estão fortemente focadas no mercado local e são seguidoras de tendências tecnológicas internacionais (SEBRAE, 2006).

Não diferindo da situação geral no Brasil, são poucas as empresas que possuem certificação em qualidade, apesar dos números ainda não serem tão expressivos, eles representam $25 \%$ do total das empresas certificadas no país. Boa parte dos empresários tem interesse em melhorar seus processos e produtos de software e obter certificação (FUMSOFT, 2007).

Um aspecto positivo no caso do pólo de $\mathrm{BH}$ é que há um movimento de articulação dos principais agentes do setor para promover a capacitação das empresas em melhorias de processos de software e preparo para certificação. Mais do que isso, existe preocupação local em criar diálogo entre empresas, órgãos do governo, universidades e instituições de apoio. Os principais agentes estão articulados e envolvidos tecnicamente numa ampla rede de cooperação para promover integração econômica e social em âmbito local.

As entidades e instituições de apoio organizam-se num conselho único denominado Conselho de Empresas de Informática de Minas Gerais (CEINFOR), que reúne no estado os principais representantes do setor em torno de uma agenda única de desenvolvimento. Há alta convergência de interesses entre os representantes e as ações são planejadas e muitas executadas em conjunto, aproveitando a experiência e as competências de cada organização no 
planejamento e operacionalização do projeto de desenvolvimento local. Maiores detalhes sobre este assunto serão apresentados no próximo tópico.

\subsubsection{Agentes de Coordenação Local e suas funções}

As principais instituições de coordenação local estão voltadas aos interesses do APL com uma proposta ampla de desenvolvimento, na qual a melhoria e qualidade de processos de software é uma entre as prioridades.

O SEBRAE-MG é uma instituição de fundamental importância para o setor no apoio em capacitação gerencial, mercadológica, orientação para o crédito e atividades e negócios que contribuam para a geração de emprego e renda. É a entidade criadora e gestora do projeto denominado Desenvolvimento e Fortalecimento do setor de tecnologia da Informação/Indústria de Software de Belo Horizonte. Responsável pelo fomento e transformação do modelo de desenvolvimento setorial para o modelo de APL. O programa tem como objetivo o incremento da indústria de software local com a formalização e utilização de uma metodologia de gestão de APL orientada em resultados (SIGEOR - Sistema de Gestão Orientada em Resultados).

Principais objetivos do projeto: incremento da qualidade do software produzido em $\mathrm{BH}$ mediante capacitação e certificação das empresas em técnicas e processos aceitos internacionalmente; reconhecimento nacional e internacional do software de $\mathrm{BH}$ como um produto de qualidade por meio de um marketing agressivo e da consolidação da imagem do APL; estabelecimento de canais de comercialização do produto belo-horizontino nos mercados nacional e internacional.

Metas do projeto: i) elevar em $17 \%$ o faturamento anual das empresas da industria de $\mathrm{BH}$ até dezembro de 2007 , decorrente das vendas no mercado interno e externo; ii) elevar em 20\% a mão de obra qualificada (para as pessoas com qualificação mínima de curso superior) trabalhando nas empresas do APL até dezembro de 2007; iii) atingir o número de 25 empresas do APL da industria de software de BH avaliadas em CMM, CMMI ou MPS.BR até dezembro de 2007. 
A ASSESPRO é a instituição responsável por representar politicamente o setor e definir regras éticas de convivências intra e intersetores. No âmbito do projeto de desenvolvimento do APL destacam-se suas ações em fomentar o associativismo com fins comerciais e representar institucionalmente o setor.

A SUCESU é outra entidade importante localmente que tem por missão representar e defender os interesses dos usuários de informática e telecomunicações, por meio de ações políticas, institucionais e éticas, fomentando e disseminando o uso das tecnologias da informação. No âmbito do projeto de desenvolvimento do APL de software suas principais ações são: representar os usuários de software, desenvolver elo entre produtores e consumidores e indicar tendências mapeando demandas do mercado.

O SINDINFOR é a entidade patronal que tem a finalidade de defender, orientar, coordenar e representar legalmente a categoria econômica das empresas de processamento de dados do Estado de Minas Gerais perante a representação dos trabalhadores. No âmbito do projeto de desenvolvimento local de software destacam-se suas ações de promover um fórum de desenvolvimento do APL do qual emergirão grupos temáticos de discussão dentro do arranjo e levantar Indicadores das empresas da industria de software de $\mathrm{BH}$.

A FUMSOFT é uma instituição privada, sem fins lucrativos, fundada em 1992 pelas empresas mineiras de software estabelecidas em Belo Horizonte, cujo objetivo principal é o fomento do setor de software na região, visando ampliar a participação dessas empresas no mercado nacional e internacional. Faz parte de um dos 33 núcleos do Programa SOFTEX. Dentro do escopo deste trabalho, a FUMSOFT é a principal instituição de coordenação local voltada à promoção de ações de cooperação e interação das MPME's de software. Desde 2002 vinha desenvolvendo o programa "Rumo ao CMM e CMMI, aderindo-se em 2003 ao Projeto MPS.BR. Criou um novo núcleo com a missão de promover a qualificação e a certificação de pequenas e médias empresas de TI de Minas Gerais, o Centro de Competência em Qualidade e Produtividade (CCOMP.MG) nos modelos MPS.BR e CMMI. Em 2005 tornou-se Instituição Implementadora (II) e Instituição Organizadora de Grupos de Empresas (IOGE). Para isso foram formadas parcerias com empresas do mercado, 
empresas públicas, universidades e organismos de incentivo e fomento. A FUMSOFT através do CCOMP-MG tem apresentado os maiores números de empresas avaliadas no Brasil. De 2006 até final de 2007 foram 31 empresas que já participaram do programa MPS.BR, sendo 27 empresas participantes do modelo cooperado de aprendizado e 4 do modelo de negócio específico. Três empresas que implementaram nível $G$ buscam nível $F$ e duas empresas que alcançaram nível $F$ estão investindo na implementação do nível C do MPS.BR (vale mencionar que neste últimos caso tratam-se de duas empresas de grande porte do setor público de Belo Horizonte. A partir de outubro de 2007 a entidade foi oficialmente aprovada e credenciada como Instituição Avaliadora (IA) do MPS.BR no Brasil, o que lhe deu o status único de agente completo nos processos relativos à melhoria e qualidade (envolvendo certificação) de processos de software. No próximo tópico será apresentado maiores detalhes a respeito da forma de interação/cooperação e disseminação do conhecimento no âmbito dessa rede de conhecimento em melhoria e qualidade de processo de software.

Outras instituições têm apoiado a realização do projeto de desenvolvimento do APL:

A Prefeitura de Belo Horizonte tem apoiado o setor através da interação e engajamento no empreendimento do Parque Tecnológico de Belo Horizonte que será sediado na Universidade Federal de Minas Gerais. Este será um empreendimento viabilizado através de uma parceria entre a UFMG, o Governo do Estado de Minas Gerais, a Prefeitura da cidade, a FAPEMIG e o SEBRAE.

A FAPEMIG - Fundação de Amparo à Pesquisa do Estado de Minas Gerais tem apoiador o desenvolvimento de pesquisa no Estado de Minas Gerais através de editais de financiamento.

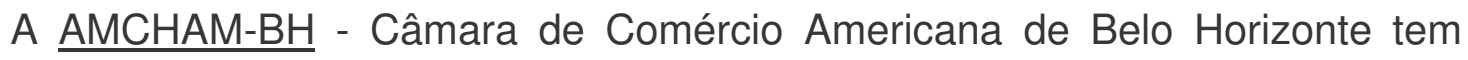
como missão servir seus associados influenciando construtivamente políticas públicas no Brasil e nos Estados Unidos, promovendo o comércio, o investimento e a cidadania empresarial. Suas principais ações no projeto de desenvolvimento do APL é promover o setor de software junto ao seu público 
A SECTES - Secretaria de Estado de Ciência, Tecnologia e Ensino Superior de Minas Gerais é o órgão do governo estadual responsável para atuar junto ao APL em nome do governo. A Secretaria é interlocutora do setor com as autoridades governamentais do Estado.

O $\underline{B D M G}$ - Banco de Desenvolvimento de Minas Gerais é um dos apoiadores do setor financiando projetos das empresas locais.

A tabela 5.1 apresenta algumas das ações planejadas pelos agentes de coordenação do setor na dinâmica de desenvolvimento do pólo de software de Belo Horizonte. 
Tabela 5.1: Ações das instituições de coordenação do APL de Belo Horizonte (continua)

\begin{tabular}{|c|c|}
\hline Ações & $\begin{array}{l}\text { Entidade } \\
\text { Executora }\end{array}$ \\
\hline Apresentar o projeto ao poder público & SINDINFOR \\
\hline Coordenar Fórum de Desenvolvimento /CEINFOR & SINDINFOR \\
\hline Divulgar o APL da indústria de software de $\mathrm{BH}$ & SINDINFOR \\
\hline Divulgar institucionalmente o APL em feiras e eventos & SINDINFOR \\
\hline Fortalecer os eventos realizados pelo APL & SINDINFOR \\
\hline $\begin{array}{l}\text { Viabilizar de forma efetiva a participação em missões empresariais } \\
\text { nacionais e internacionais }\end{array}$ & SINDINFOR \\
\hline $\begin{array}{l}\text { Levantar e acompanhar indicadores das empresas da indústria de } \\
\text { software }\end{array}$ & SINDINFOR \\
\hline Interagir com o Parque Tecnológico & SINDINFOR \\
\hline Criar Programa MG Software & FUMSOFT \\
\hline Coordenar Centro de apoio ao empresário da indústria de software & FUMSOFT \\
\hline Consolidar Centro de Competência em Qualidade e Produtividade & FUMSOFT \\
\hline Promover Centro Integrado de Negócios / Fábrica de software & FUMSOFT \\
\hline $\begin{array}{l}\text { Propor o desenvolvimento de linhas de crédito adequadas para os } \\
\text { negócios das empresas do APL }\end{array}$ & FUMSOFT \\
\hline Promover Programa de Apoio à investidores & FUMSOFT \\
\hline Promover Programa de apoio à exportação & FUMSOFT \\
\hline Criar marketing institucional do APL de software de $\mathrm{BH}$ & SEBRAE-MG \\
\hline Desenvolver site institucional do APL & SEBRAE-MG \\
\hline $\begin{array}{l}\text { Implantar programa de estratégia de abordagem da cultura da } \\
\text { cooperação }\end{array}$ & SEBRAE-MG \\
\hline Realizar diagnóstico da indústria de software & SEBRAE-MG \\
\hline Apoiar consultorias e cursos de gestão & SEBRAE-MG \\
\hline Gerir o Projeto & SEBRAE-MG \\
\hline $\begin{array}{l}\text { Apresentar solicitação de edital para captação de recursos da } \\
\text { FAPEMIG }\end{array}$ & SECTES \\
\hline $\begin{array}{l}\text { identificar demandas e ofertas de qualificação de recursos humanos } \\
\text { em TI }\end{array}$ & SECTES \\
\hline Articular parcerias com grandes empresas nacionais e internacionais & SECTES \\
\hline $\begin{array}{l}\text { Implantar centros de desenvolvimento tecnológico de grandes } \\
\text { empresas da área de } \mathrm{Tl} \text { em } \mathrm{BH}\end{array}$ & SECTES \\
\hline
\end{tabular}




\begin{tabular}{|l|l|}
\hline Apoiar a participação comercial em feiras e eventos setoriais & ASSESPRO-MG \\
\hline $\begin{array}{l}\text { Informar o mercado como adquirir software } \\
\text { Software e Serviços de Informática }\end{array}$ & ASSESPRO-MG \\
\hline $\begin{array}{l}\text { Levar continuamente às universidades as necessidades de } \\
\text { desenvolvimento de tecnologias de acordo com as demandas de } \\
\text { mercado }\end{array}$ & SUCESU \\
\hline Participar na Inforuso (evento de TI de Minas Gerais) & SUCESU \\
\hline Promover a visibilidade do APL de software de BH & AMCHAM-BH \\
\hline
\end{tabular}

Fonte: Síntese da autora baseada em informações do SEBRAE (2006)

Vale destacar que o projeto de capacitação das empresas mineiras em qualidade e melhoria de processos de software é uma das prioridades nas ações do Governo de Minas, entretanto a atuação da Prefeitura de Belo Horizonte aparece muito tímida comparada àquela das instituições locais de apoio. As entidades ligadas ao setor têm procurado discutir com as instituições de ensino locais como criar maior aproximação destas com as empresas de software do APL. Aliás este parece um gargalo na geração de conhecimento local. Há críticas sobre a produção científica das universidade que indicam estar distanciada da realidade das empresas.

\subsubsection{Interações e Processos de aprendizado no APL de Belo Horizonte}

Pôde-se identificar alguns tipos expressivos de interação e aprendizado entre os agentes do arranjo produtivo de software de Belo Horizonte.

\section{- Interação e Cooperação de empresas com instituições e programas de apoio}

Pode-se afirmar que o papel desempenhado pelas instituições de apoio ao setor (FUMSOFT, ASSESPRO, SUCESU, SEBRAE, SINDINFOR) em Belo Horizonte tem sido fundamental para a geração de conhecimento e aprendizado das empresas. A interação e o grau de satisfação com as atividades desempenhadas pelas entidades é considerado muito satisfatório. É notório para as empresas o 
esforço de cooperação técnica entre as entidades para promover e incentivar o desenvolvimento do setor.

A promoção da capacitação técnica e gerencial das empresas é um ponto forte no pólo de Belo Horizonte. Os serviços prestados pelas instituições estão baseados em diagnóstico das necessidades das empresas locais. São muitos os eventos que atuam como fonte de conhecimento e promovem a interação das empresas, tais como: Café da Manhã Empresarial Mensal, onde por meio de palestras com temas de interesse apontados pelos empresários e técnicos do setor de $\mathrm{Tl}$ as empresas têm a possibilidade de atualizarem-se e de estabelecer contatos com outros profissionais. Treinamentos em assuntos técnológicos e de gestão além de uma agenda farta de eventos anuais voltados para o setor de TI também são importantes fontes de conhecimento e que propiciam interação e aprendizado entre as empresas.

No mês de novembro de 2007, Belo Horizonte sediou o terceiro encontro do MPS.BR para troca de experiências das empresas, de implementadores e avaliadores do programa e de Instituições Organizadoras de Grupos de Empresas (IOGES). Ocasião em que se pôde conhecer a importância e amplitude do trabalho do CCOMP e de seus parceiros na meta de capacitar e certificar as empresas mineiras de software. A transferência de conhecimento e geração de aprendizado das empresas no âmbito do projeto MPS.BR se dá dentro de várias ambientes de interação. Desde a divulgação do evento junto às empresas, onde é esclarecido o programa MPS.BR e onde portanto, essas empresas passam a ter conhecimento de uma metodologia de melhoria de processos e das possibilidades de conquistarem uma certificação, bem como pelo conhecimento das obrigações contratuais e técnicas que as empresas assumirão e estabelecimento de uma agenda única de planejamento das atividades. Também na interação técnica individualizada entre consultores e empresas, gestores do projeto e empresas e nos workshops intermediários e final de empresas para troca de experiências sobre práticas, dificuldades e lições aprendidas. Este último tem apresentado bons resultados inclusive gerando subgrupos de atividades e troca de informações entre as empresas. As principais motivações das empresas manifestadas na pesquisa para 
buscar a melhoria de seus processos foram: redução de erros e estimativas, melhoria no controle dos projetos, melhoria na qualidade do produto final.

Quanto às vantagens em participar de um modelo cooperado de negócio para aquisição de conhecimento, as empresas destacam além da redução nos custos de implementação e avaliação, a troca de experiências entre as empresas cooperadas como uma importante fonte de conhecimento que ajuda dentre outras coisas a identificar os pontos fortes e fracos da empresa em relação às demais do mercado. O papel da Instituição Implementadora também é importante no sentido de criar sanções para as empresas que não cumprem o planejamento coletivo estabelecido, o que força a dedicação dos sponsors ao projeto de melhoria.

Uma dificuldade destacada na avaliação cooperada foi a necessidade de acompanhamento de um calendário e marcos que muitas vezes não se ajustam à necessidade individual das empresas, o que pode trazer imprevistos aos projetos de melhoria. Embora as empresas reconheçam a importância das ações das entidades representativas do setor, a pesquisa identificou a falta de maior articulação local para fomentar a cooperação, no sentido de conscientizar as empresas de que esta não significa perda de competitividade. 


\section{Interação entre empresas de software do pólo (inclusive concorrentes)}

Uma estrutura de difusão de conhecimento identificada bastante atraente para a promoção do conhecimento coletivo foi a comunidade de prática de profissionais de software de Belo Horizonte, denominada Núcleo SPIN-BH (Software and Systems Process Improvement Network ${ }^{14}$ de Belo Horizonte). Trata-se de uma organização integrante da Rede de Melhoria de Processos de Software filiada ao Software Engineering Institute $(\mathrm{SEI})^{15}$ responsável pelo desenvolvimento dos diversos modelos de maturidade e capacidade CMM, que se integraram e evoluíram para o CMMI. O movimento SPIN chegou ao Brasil em 1997, com a formação do primeiro núcleo brasileiro, o SPIN São Paulo. Desde então, surgiram cerca de mais 17 SPIN's espalhados por 12 estados brasileiros, sendo que boa parte destes encontra-se ainda emergente ou em fase de estruturação.

Criado em agosto de 2003, os objetivos do SPIN-BH incluem incentivar as organizações a promover a melhoria dos processos de aquisição, fornecimento, manutenção, desenvolvimento e suporte de software, aumentando a conscientização sobre os benefícios do investimento na melhoria destes processos; possibilitar a troca de experiências entre empresas, universidades e profissionais e governo sobre a implantação e manutenção de programas de melhoria de processos de software e contribuir para o aprimoramento da capacitação de recursos humanos, sintonizando-os com as necessidades reais do mercado. Opera com tempo e recursos voluntários. As atividades realizadas incluem painéis, treinamentos, palestras e reuniões sobre melhoria de processos de software visando criar um

\footnotetext{
${ }^{14}$ O conceito de SPIN surgiu em $1988 \mathrm{com}$ um grupo de profissionais da área de processo, em Washington, EUA. Estes profissionais sentiram a necessidade de um fórum prático para a troca de idéias, informações e suporte mútuo, fundando então o primeiro núcleo SPIN, que iniciou um trabalho de fomento à inovação na prática da engenharia de software pelo mundo. Como o SEI não conseguiria apoiar todos os esforços de melhoria estes profissionais decidiram criar um mecanismo pelo qual, interagindo com os SEPGs (Software and Systems Engineering Process Groups), pudessem trocar experiências, compartilhar conhecimentos e fornecer suporte mútuo, assim como obter serviços que não fossem prestados pelo SEI. Até 2007 eram 114 SPINs espalhados pelo mundo. Apesar da idéia e gerenciamento da rede de SPIN's ser proveniente do SEI, os núcleos SPINs são autônomos e geralmente discutem a melhoria de processos de software e sistemas em geral, atendendo aos anseios da comunidade brasileira e à disseminação do uso dos modelos MPS.BR, CMMI e de outras normas relacionadas à qualidade de software, além de metodologias e técnicas relacionadas a gerenciamento, desenvolvimento e testes de software (MAGALHÃES et. al, 2007)

${ }^{15}$ O SEI (Software Engineering Institute) é um centro de pesquisa e desenvolvimento da Carnegie Mellon University patrocinado pelo Departamento de Defesa dos Estados Unidos.
} 
fórum para uma troca livre e aberta de conhecimento, experiências e idéias em melhoria de processos de software, divulgação de informações e novidades sobre o desenvolvimento da prática e de pesquisas relacionadas ao assunto. O SPIN-BH tem conseguido manter uma estrutura eficiente com poucos recursos e benefícios para comunidade por meio da disseminação da melhoria de processo de software. Tem possibilitado aos participantes uma interação rica e constante, seja de forma presencial ou a distância (lista de discussão na internet com o objetivos de disseminar as melhores práticas na região). A formação de um núcleo desta natureza representa um passo no compromisso da cooperação com a melhoria de processo de software e sistemas e uma oportunidade de as empresas efetivarem uma rede de conhecimento especializado.

\section{- Interação produtor-clientes}

Fontes de informações oriundas de clientes são consideradas importantes para o desenvolvimento de capacitações conjuntas no universo das empresas desenvolvedoras de software e de produtos customizados.

\section{- Interação das empresas com centros de pesquisa e instituições de ensino locais}

A pesquisa não identificou a interação ou o uso de fontes científicoacadêmicas como forma de obtenção de conhecimento em melhoria e qualidade de processos de software por parte das empresas. O que foi possível identificar foi a participação da UFMG como parceira no projeto de incubadora de empresas gerido pela FUMSOFT. Entretanto, esta lacuna de oportunidade de geração de conhecimento já foi identificada em pesquisa realizada junto às empresas por entidades locais e algumas ações estão sendo discutidas no sentido de gerar maior aproximação das atividades acadêmicas e de pesquisa ao universo das empresas de software locais.

Fontes de conhecimento sobre melhoria e qualidade de processos obtidas na Internet também foram identificadas na pesquisa, porém com menor expressividade. 
Os mecanismos internos de aprendizado (learning by using, learning by doing) através da experiência de produção foram considerados relevantes para a geração de inovações incrementais em produtos e processos de software.

Dentre as vantagens da localização das empresas de software de Belo Horizonte foram mencionadas o bom nível de formação técnica e superior da mão de obra local, infra-estrutura física adequada ao setor e boa representatividade do setor.

\subsection{Origem e desenvolvimento do APL de Blumenau}

As primeiras atividades em software e serviços de informática em Blumenau surgiram no contexto de grande desenvolvimento da indústria têxtil no município, quando um grupo de empresas têxteis se propuseram a cooperar para fundar um grande empreendimento empresarial na área de informática em 1969, o CETIL Centro Eletrônico da Indústria Têxtil, que se transformou em pouco tempo no maior birô de serviços do país, chegando a ter filiais em quase todos os estados brasileiros.

Com o advento da microinformática, os serviços de informática processados pelos grandes mainframes perderam espaço. As empresas foram gradativamente investindo em equipamentos e abandonando a terceirização representada pelos birôs. Com o declínio das atividades do CETIL, muito profissionais formaram suas próprias empresas ou foram trabalhar para outras. Assim, em função da vasta acumulação de conhecimentos e capacitações gerados pelo CETIL e das baixas barreiras à entrada que caracterizaram a atividade de software na época, novos empreendimentos de software foram criados, o que deu origem ao pólo de empresas de software, a partir da década de 80.

A partir de então, Blumenau registrou conquistas importantes ainda no ambiente DOS. A WK Sistemas criou o primeiro aplicativo com janelas sobrepostas. A Fácil Informática lançou no mercado um processador de textos para Windows, 
sendo o primeiro a apresentar acentuação automática e a colocar hífen nas palavras, além de deter um bom corretor ortográfico. Também foram lançados o primeiro compressor de dados (Stress) e a primeira planilha brasileira (Easy Calc).

O início da década de 90 encontrou Blumenau com cerca de 40 empresas de informática, com faturamento estimado de $\mathrm{R} \$ 30$ milhões e com aproximadamente 200 empregos diretos gerados pelas novas empresas.

O primeiros empreendimentos se concentraram, de início, na produção de software horizontal (processadores de texto) e de automação de escritórios (contabilidade, recursos humanos, entre outros). Nos últimos anos, o pólo tem se consolidado como produtor de soluções para gestão.

Um levantamento do BNDES em 2007 (GUTIERREZ, 2007) mostra que o segmento de sistemas integrados de gestão se divide em três segmentos: grande porte $(31 \%)$, médio porte $(41 \%)$ e pequeno porte $(28 \%)$. Os dois primeiros são dominados por grandes grupos internacionais como SAP, Oracle e People Soft. A indústria nacional de software domina o segmento de pequeno porte, que movimenta perto de U\$ 85 milhões/ano.

De acordo com os dados do BNDES, esse mercado é dominado por 10 empresas nacionais. Quatro estão situadas em Santa Catarina. Uma delas tem sede em Joinville, a Logocenter, que detém 1,1\% do mercado. As outras três são de Blumenau e têm as seguintes participações no mercado de sistemas integrados de gestão: Benner Sistemas (3,3\%), Senior Sistemas $(7,1 \%)$ e WK Sistemas $(2,4 \%)$.

A presença de mercado de Blumenau é representada por 5,5\% das empresas de software do país. O pólo produz sozinho 12\% dos ERP's para pequenas empresas. O setor tem apresentado crescimento médio de $20 \%$ ao ano, empregando aproximadamente 6000 (seis mil) pessoas. O faturamento do setor foi estimado em 2006 em $\mathrm{R} \$ 300$ milhões de reais. (Dados fornecidos pela BLUSOFT, 2007). 
Observa-se um índice baixo de subcontratação das atividades de desenvolvimento, ou seja, o que significa que as empresas integram o processo de produção de software.

Para sustentar seu poder de vendas e sua capacidade de assistência técnica, várias empresas mantêm filiais fora de Blumenau e estabelecem, inclusive, alianças com outras empresas.

Vale destacar no desenvolvimento econômico de Blumenau alguns aspectos importantes relacionados ao capital social local, tais como uma cultura ativista voltada à ação e cooperação e aos interesses coletivos, que tem se manifestado ao longo da trajetória histórica local, manifestados no dinamismo industrial que caracterizou a cidade desde sua fundação e em momentos de caos social, como por ocasião da grande enchente em 1983 e 1984, que praticamente destruiu a cidade, mas não "a coragem e a disposição do povo local" (SILVA, 1989). Estes fatores ajudam a compreender algumas das condições sócio-culturais que tornaram possível o surgimento e o desenvolvimento da nova atividade de base tecnológica de Blumenau: o software.

O fato de muitas empresas terem sido formadas a partir da experiência do CETIL (mesma matriz tecnológica-social) também contribuiu para facilitar o desenvolvimento de interações e relações cooperativas entre as empresas.

As ações conjuntas dos novos empresários locais também foram responsáveis pelas principais conquistas institucionais de apoio ao setor. Preocupados em dar projeção nacional às atividades de software desenvolvidas, estes empresários ativaram suas associações de classe e envolveram a administração local do município em iniciativas do setor. A prefeitura de Blumenau foi uma das pioneiras em adotar uma política na área da informática visando a formação e desenvolvimento do pólo, o que contribuiu para o aprimoramento das conquistas obtidas pelo setor e para o desenvolvimento local.

No início dos anos 90, com a política de abertura comercial que instalou-se no país, algumas instituições de âmbito local e regional (ACIB- Associação Comercial e 
Industrial de Blumenau, ASSESPRO - SC, e a FURB - Fundação Universidade Regional de Blumenau) juntaram-se para buscar medidas de apoio. Buscava-se apoio ao desenvolvimento tecnológico e empresarial e ações de apoio à comercialização.

$\mathrm{O}$ ato culminou em importantes incentivos concedidos às empresas locais através da Prefeitura e em 1992, como parte da resposta à esta mobilização, foi fundada a BLUSOFT - uma associação de empresas de tecnologia, resultado da articulação do empresariado da cidade. Esta associação foi e ainda é a principal referência local de coordenação dos agentes. Desde a sua fundação tem contribuído significativamente na obtenção de conquistas e crescimento do pólo.

Assim, pode-se dizer que diferentemente de outros locais, onde a participação pública tem papel significativo no processo de conformação do pólo, em Blumenau, as ações conjuntas entre empresários foram cruciais para mobilizar outras instituições locais como a Prefeitura e a Universidade através da renovação de seus cursos especializados.

Desta forma, as interações locais foram se consolidando sob a iniciativa dos empresários locais ou de seus órgãos representantes.

\subsubsection{Agentes de Coordenação Local e suas funções}

As principais instituições de coordenação local em Blumenau são basicamente três:

A BLUSOFT - Blumenau Pólo Tecnológico de Informática - é uma associação privada sem fins lucrativos, com a missão de apoiar e estimular 0 desenvolvimento do software em Blumenau, através da qualificação e consolidação das empresas do setor. Canaliza recursos financeiros, bolsas de trabalho e equipamentos. Em seus 15 anos de atuação viabilizou em suas atividades recursos 
da ordem de $\mathrm{R} \$ 14$ milhões de reais em benefício do setor. Esses recursos foram obtidos através de parceria com a ANPROTEC - (Associação Nacional de Entidades Promotoras de Empreendimentos de Tecnologias Avançadas), a FINEP Financiadora de Estudos e Projetos, o CNPq - Conselho Nacional de Pesquisas e o SEBRAE - Serviço Nacional de Apoio às Micro e Pequenas Empresas. Suas principais ações ao longo dos anos envolvem atividades de marketing do pólo, acesso das empresas à fontes de financiamento (como já citado), e ações de capacitação, principalmente na área técnica, procurando atender a demanda empresarial do setor. A entidade se sustenta através da contribuição dos associados, do apoio da Prefeitura, da FURB (Fundação Universidade Regional de Blumenau) e da ASSESPRO.

Uma das principais demandas das empresas locais tem sido de mão de obra especializada. Assim, a BLUSOFT abriga o Projeto Entra 21 de formação técnica de jovens para ajudar a abastecer o mercado de trabalho da Tecnologia de Informação. São 200 novas vagas abertas anualmente. Os jovens recebem uma formação básica em Windows, Excel, Powerpoint, Internet, MS-Project e Iniciação Gráfica e, posteriormente são encaminhados para estágios nas empresas onde recebem uma formação extensiva voltada para áreas específicas, como desenvolvimento de sistemas, suporte e servidores de rede, manutenção de hardware, entre outras. Trata-se de um projeto de co-financiamento das empresas junto com a Prefeitura.

Na qualidade de Agente SOFTEX regional, a BLUSOFT abriga também uma incubadora de empresas, que é uma importante referência na geração de conhecimento e aprendizado local.

No Estado de Santa Catarina, outros pólos de software como Joinville e Florianópolis também consolidaram-se a partir da ação conjunta de associações de empresas, das universidades, das incubadoras e de instituições como o CNPq, FINEP, SEBRAE e outras. Embora muito próximos localmente, esses pólos nunca foram alvo de uma ação sistemática conjunta, mas de iniciativas coletivas pontuais, em geral, focadas nas áreas comercial e tributária (CORAL et al., 2007). 
Para criar um projeto conjunto e sistemático, em 2001, sob a coordenação do Instituto Euvaldo Lodi - IEL, iniciou-se um mapeamento da cadeia produtiva de software nos três pólos identificados, a fim de realizar um diagnóstico que identificasse os principais gargalos na competitividade das empresas catarinenses do setor de TI. Esse projeto envolveu a participação e interação de várias instituições públicas e privadas dos pólos de Blumenau, Joinville e Florianópolis. Foram realizados estudos sobre as necessidades do setor de $\mathrm{TI}$ envolvendo formação, P\&D e serviços.

Com base nos gargalos identificados o IEL/SC organizou a elaboração de um projeto dentro dos princípios de uma plataforma (onde todos os desenvolvimentos auferidos são compartilhados por todos os participantes de um programa). O projeto buscou apoio e financiamento sendo aprovado, e denominou-se Projeto PLATIC.

O projeto identificou uma série de prioridades em termos de serviços e P\&D para tornar a gestão do negócio de software mais efetiva para as empresas dos pólos. Assim, o PLATIC organizou-se num objetivo principal de desenvolver ferramentas de gestão de negócio, padronização de processos e produtos de software, disponibilizando estas ferramentas às empresas do setor por meio do desenvolvimento de metodologias e criação de núcleos de competências nas áreas identificadas pelas empresas.

O projeto foi organizado em sub-projetos com equipes responsáveis pela sua operacionalização. Os resultados dos gargalos foram determinantes na criação de dois núcleos responsáveis pela melhoria de processo de software (CMMI), dado o grande número de empresas interessadas por este serviço. O PLATIC reuniu seis instituições de ensino e pesquisa, 61 pesquisadores, dois órgãos financiadores, a instituição gestora e 49 empresas que contribuíram com contrapartida financeira.

Foram traçadas 12 metas, dentre as quais, relacionadas ao escopo desta tese, vale mencionar três delas.

META 1 - RUMO AO CMMI-SW NÍVEL 2 PARA MPMEs - voltada à melhoria da qualidade do processo de desenvolvimento, ficando sob a responsabilidade do 
Laboratório de Qualidade e Produtividade de Software da UNIVALI- Universidade do Vale do Itajaí desenvolver uma abordagem para melhoria de processos baseada no CMMI/SW. Cinco empresas participaram de modo cooperado na implementação e avaliação do processo

META 2 - MELHORIA DE PROCESSO - CMMI - visou contemplar todos os requisitos da meta com a finalidade de desenvolver uma metodologia de qualificação de processo de desenvolvimento de software. Ficou sob a responsabilidade da UNIVILLE - Universidade da Região de Joinville por meio de seu Departamento de Sistemas de Informação.

META 3 - NÚCLEO DE AVALIAÇÃO DA QUALIDADE DE PRODUTOS DE SOFTWARE - teve como objetivo desenvolver uma metodologia de avaliação da qualidade de produtos de software a partir de métodos existentes e a experiência adquirida com as avaliações realizadas. O foco para esta metodologia foi a avaliação com base em normas internacionais como ISO/IEC 9126, ISO/IEC 15504 entre outras. Esta meta ficou sob a responsabilidade do Laboratório de Qualidade de Software (LQS) da FURB, em Blumenau, uma vez que a pesquisa sobre gargalos identificou esta maior necessidade. A partir de 2004, o LQS passou a contribuir na melhoria da qualidade dos produtos das empresas locais. Entretanto, o que se observa no pólo de Blumenau é ainda iniciativas isoladas por parte das empresas em processos de avaliação da qualidade de software.

A FURB, na trajetória de desenvolvimento do pólo, tem destacada importância na formação de recursos humanos e conhecimento local nutrindo a industria de software e também induzindo novos empreendimentos de software. É a principal universidade de Blumenau, possuindo 2 cursos de graduação e pósgraduação na área de TI. Possui também uma pré-incubadora de empresas por meio dos programas nacionais SOFTEX e GENE. Vários professores são empresários ou empregados na indústria de software de Blumenau o que difunde os vínculos informais para a a troca de informações e transmissão de conhecimentos.

Quanto à geração de conhecimento local em nível institucional quanto à melhoria e qualidade de processos, pode-se dizer que o Projeto PLATIC foi a 
principal referência, favorecendo a aproximação das empresas com os centros de pesquisa e sedimentando a criação de núcleos de excelência.

Mesmo com alguns percalços no desenrolar do projeto, como atrasos na sua aprovação, na liberação de recursos por fontes financiadoras, na disputa política pela governança do projeto, que afetou a credibilidade das empresas envolvidas, é inegável a contribuição do mesmo na criação de competências institucionais locais e regionais, na criação de spillovers de conhecimento e de um fórum agregador das entidades representativas do setor, o CETIC.

\subsubsection{Interações e Processos de aprendizado no APL de Blumenau}

O tipos mais expressivos de interação e aprendizado em melhoria e qualidade de software identificados no pólo de Blumenau pela pesquisa foram:

\section{- Interação das empresas com entidades de apoio e instituição de ensino local:}

Os aspectos principais com respeito a este tipo de interação já foram explanados no tópico anterior. Entretanto, vale mencionar que um dos principais gargalos das empresas em processos de desenvolvimento de software também estão relacionados à escassez de mão de obra qualificada (que pode demonstrar uma provável deseconomia de aglomeração) É recente a preocupação das empresas com a questão da melhoria de processos de software, parte desta preocupação tem sido motivada em função de um trabalho institucional local com as empresas, mais fortemente de caráter informal do que formal. Em vista disto, as empresas têm buscado através de seus profissionais, muitos deles alunos de graduação e outros de mestrado incorporar em seus processos boas práticas de melhoria. Assim, os alunos das instituições de ensino superior local têm atuado como multiplicadores do conhecimento sobre metodologias de melhorias de processo. Isto demonstra a importância em se criar uma interface maior com as empresas e criar canais e códigos de comunicação mais efetivos. Outra fonte de conhecimento local informal, já citada anteriormente, são os alguns professores de 
cursos da área de TI que também trabalham ou possuem empresas de software. Outras fontes externas de conhecimento foram mencionadas, tais como as feiras, eventos e encontros informais e foram considerados de relativa importância na geração de conhecimento.

\section{- Interação produtor-cliente}

A pesquisa identificou junto aos empresários que uma das principais preocupações em melhorias de processo de desenvolvimento de software estão relacionadas às demandas de seus clientes. As empresas atuam junto à estes e procuram incorporar ao produto e aos serviços os requisitos exigidos. A pesquisa apontou que as empresas manifestam preocupação em terem bons processos de software, mas não necessariamente uma certificação.

Quanto às externalidades locais, as empresas mencionaram duas importantes economias de aglomeração, entre elas, o baixo custo da mão de obra, a reputação positiva do pólo de Blumenau. A escassez de mão de obra qualificada foi apontada como uma desvantagem atual do local.

\subsection{Análise comparativa da dinâmica de interações e aprendizagem nos APLS de software}

Esta seção tem por objetivo apresentar uma análise crítica e comparativa dos casos estudados, com enfoque nas formas de geração de conhecimento via processos de interação e cooperação nos arranjos produtivos locais estudados e os efeitos destas relações para o aprendizado e a ampliação das capacitações das pequenas e médias empresas.

\subsubsection{Análise dos principais aspectos de origem e desenvolvimento dos APL's}

A análise das características de origem e desenvolvimento dos arranjos produtivos permitiu identificar os principais aspectos que definiram as 
especificidades de funcionamento local e influenciaram a estrutura competitiva, a dinâmica das interações, e, obviamente, a geração de conhecimento e aprendizado.

Em Campinas, o desenvolvimento do pólo baseou-se na implantação e trajetória das grandes empresas intensivas em tecnologia atraídas pela existência de um conjunto de iniciativas públicas de fomento, que não diretamente voltadas à atividade de software, mas de atividades correlatas, estimularam o surgimento e desenvolvimento de um pólo industrial bastante expressivo.

Há presença no pólo de fortes capacitações técnicas adquiridas ao longo de um processo de intensa interação entre os agentes produtivos locais e instituições de apoio, como foi o caso do CPqD e a UNICAMP. Portanto, a análise da trajetória de desenvolvimento do pólo de Campinas revela uma forte dependência da infraestrutura local de ensino e pesquisa que apresenta ainda características herdadas de sua origem. Destacam-se também as vantagens advindas das forças de mercado decorrentes da aglomeração e spillovers tecnológicos e de conhecimento inerentes a esta forma de organização das firmas.

Segundo La Rovere e Carvalho (2004), pode-se dizer que os ganhos advindos da concentração espacial das empresas do pólo de Campinas estiveram mais associados à obtenção de eficiência coletiva passiva ou de vantagens competitivas estáticas relacionadas à localização, uso de infra-estrutura, acesso à serviços de empresas e instituições locais e menos associados à vantagens competitivas dinâmicas ou ganhos de eficiência coletiva ativa, através do desenvolvimento de projetos conjuntos de inovação de produtos ou processos.

As empresas de Campinas não têm demonstrado ser dinâmicas o suficiente para articularem e desenvolverem ações conjuntas para ampliarem suas capacitações e aumentarem as eficiências coletivas locais. Um outro fator que colabora para isso é o fato das empresas acreditarem que possuem o controle de seus processos de desenvolvimento de software, tomando uma posição mais defensiva e reativa. As forças de mercado parecem estimular as empresas a buscarem seus próprios interesses e atuarem mais de forma isolada. 
Já em Blumenau, a trajetória de desenvolvimento do pólo de software está ancorada em conquistas coletivas coordenadas por ações empresariais apoiadas por políticas públicas locais. E em Belo Horizonte destaca-se o papel das associações de classe e instituições de apoio articuladas com o poder público atuando como catalisadores do desenvolvimento local.

Conforme SUZIGAN et. al, (2003) as possibilidades de desenvolvimento local são dependentes das formas de governança do sistema, neste caso, pode-se afirmar que o arranjo de Belo Horizonte, por agir de forma mais pró-ativa e dinâmica, e o de Blumenau, ainda que um pouco reativo, dependente das ações iniciativas empresarias, atuam na construção de vantagens dinâmicas que corroboram com aumento da performance econômica das empresas. A tabela 5.2 destaca os principais aspectos relacionados à origem e trajetória de desenvolvimento do pólo. 


\begin{tabular}{|c|c|c|c|}
\hline $\begin{array}{l}\text { Aspectos } \\
\text { relacionados à } \\
\text { origem e trajetória } \\
\text { dos APL's } \\
\text { (desenvolvimento } \\
\text { local) }\end{array}$ & Campinas & Belo Horizonte & Blumenau \\
\hline Origens & $\begin{array}{c}\text {-Grandes empresas } \\
\text { intensivas em } \\
\text { tecnologia } \\
\text { Forte estrutura ciência } \\
\text { e tecnologia }\end{array}$ & $\begin{array}{c}\text { Birôs de Serviços } \\
\text { de Informática }\end{array}$ & $\begin{array}{l}\text { Birôs de Serviços de } \\
\text { Informática }\end{array}$ \\
\hline $\begin{array}{l}\text { Indutores da criação } \\
\text { de empresas e } \\
\text { capacitações locais }\end{array}$ & $\begin{array}{l}\text { Mobilidade de Mão- } \\
\text { de-obra } \\
\text { Transbordamentos de } \\
\text { conhecimento }\end{array}$ & $\begin{array}{c}\text { Transbordamentos } \\
\text { de conhecimento } \\
\text { Universidade }\end{array}$ & $\begin{array}{c}\text { Transbordamentos } \\
\text { de conhecimento } \\
\text { Universidade }\end{array}$ \\
\hline $\begin{array}{l}\text { Configuração } \\
\text { produtiva local }\end{array}$ & $\begin{array}{c}\text { GE multinacionais de } \\
\text { TI } \\
\text { PME's - (UNICAMP e } \\
\text { CPQD) } \\
\text { Forte concentração } \\
\text { no desenvolvimento } \\
\text { de software } \\
\text { customizado } \\
\text { Segmentos diversos } \\
\text { Mercado } \\
\text { Nacional/internacional }\end{array}$ & $\begin{array}{c}\text { MPE's } \\
\text { Desenvolvimento } \\
\text { de software } \\
\text { customizado e } \\
\text { encomenda } \\
\text { Serviços de baixo } \\
\text { e alto valor } \\
\text { Segmentos } \\
\text { diversos } \\
\text { Mercado } \\
\text { Local/Regional }\end{array}$ & $\begin{array}{c}\text { PME's } \\
\text { Desenvolvimento } \\
\text { de software } \\
\text { customizado e } \\
\text { encomenda } \\
\text { Serviços de baixo } \\
\text { e alto valor } \\
\text { Softwares de } \\
\text { Gestão } \\
\text { Mercado } \\
\text { Nacional }\end{array}$ \\
\hline $\begin{array}{l}\text { Vantagens de } \\
\text { aglomeração }\end{array}$ & $\begin{array}{c}\text { Eficiência coletiva } \\
\text { passiva }\end{array}$ & $\begin{array}{c}\text { Eficiência coletiva } \\
\text { ativa }\end{array}$ & $\begin{array}{c}\text { Eficiência coletiva } \\
\text { ativa }\end{array}$ \\
\hline
\end{tabular}

Tabela 5.2 - Aspectos relacionados à origem e trajetória dos APL's 


\subsubsection{Governança e/ou Coordenação Local}

Segundo Humphrey e Schmitz (2000) a governança local (pública e privada) pode e deve exercer papel importante para o fomento da competitividade dos produtores aglomerados. No pólo da Campinas a organização da estrutura local do arranjo, no que se refere à promover, fomentar ou potencializar as interações e os processos de aprendizado entre os agentes está organizada de forma pouco expressiva. $\mathrm{O}$ apoio das políticas públicas locais é bastante tímido e as ações de promoção do conhecimento em melhoria de processos de software e qualidade encontram-se quase que exclusivamente concentradas no Agente SOFTEX. Atuando como Instituição Implementadora e Organizadora de Grupos de Empresas na difusão de conhecimento, seus recursos têm sido subaproveitados pelas empresas locais, mas utilizados com bons resultados por empresas de outras localidades. Um fato interessante para ser melhor explorado e conjecturado, que volta a reforçar a idéia de que as PME's têm atuado de forma isolada.

Em Belo Horizonte, bem como em Blumenau destaca-se o papel das associações de classe e de instituições locais de apoio na promoção do conhecimento e aprendizado local. Entretanto, de forma bem mais expressiva e articulada com o poder público, no APL de Belo Horizonte. Em Blumenau, as ações conjuntas dos novos empresários locais foram responsáveis pelas principais conquistas institucionais de apoio ao setor, e por importantes incentivos concedidos às empresas através de políticas públicas locais. Como parte da resposta à esta mobilização, foi fundada a BLUSOFT - uma associação de empresas de tecnologia, resultado da articulação do empresariado da cidade. Esta associação foi e ainda é a principal referência de coordenação dos agentes produtivos locais. Desde a sua fundação tem contribuído significativamente na obtenção de conquistas e crescimento do pólo. Desta forma, as interações locais foram se consolidando sob a iniciativa dos empresários locais ou de seus órgãos representantes.

Suzigan et al. (2003) afirmam que além das economias incidentais, outros benefícios dependem da existência de formas de governança que estimulem as relações cooperativas entre os agentes que levem ao incremento da competitividade coletiva dos produtores, desta forma, entende-se que as possibilidades de 
desenvolvimento local em Belo Horizonte têm sido melhor exploradas e/ou potencializadas.

\subsubsection{Geração e difusão do Conhecimento e Aprendizado}

Uma das bases principais deste estudo está ancorada no entendimento de que as interações vivenciadas pelas PME's no âmbito das aglomerações produtivas trazem-Ihes ganhos difíceis de serem alcançados atuando isoladamente. A aprendizagem como um processo é resultante da acumulação de conhecimentos no interior das firmas e de capacitações construídas através do acesso às fontes externas de conhecimento. O conhecimento adquirido poder ser fruto de mecanismos formais ou informais, de natureza implícita ou explícita.

$\mathrm{Na}$ análise da dinâmica do conhecimento dos APLs estudados foi possível verificar que a geração e difusão do conhecimento em melhoria e qualidade de processos de software ocorre através de mecanismos informais de aprendizado, de natureza implícita e internos à firma (learning by doing, learning by using), ou seja, baseado em Lundvall (1992) as capacitações das firmas são formadas no próprio ambiente de trabalho, mas também através de conhecimentos externos à firma, através do learning by interaction, onde merece destaque, a comunidade de prática SPIN em BH e o modelo cooperado de aquisição e difusão de conhecimento em metodologias de implantação de melhorias de processo de software, que não deixa de ser uma rede de cooperação de MPME's. Este fato, ao mesmo tempo em que reforça a proposição básica deste estudo em que os processos de aprendizagem por interação são determinantes para a geração de capacitações inovativas das firmas, (uma vez que as empresas de software desenvolvedoras de produtos de alto valor [customizado ou sob encomenda] têm a necessidade de manter contato com seus demandantes e usuários para a transmissão de conhecimento que são predominantemente tácitos), também considera o learning by doing e by using), em particular, importantes, para o desenvolvimento de melhorias e inovações incrementais nos processos de desenvolvimento de software. As empresas utilizam de suas próprias condições estruturais de produção interna para implantarem mudanças técnicas em processos e produto (este fato ajuda a compreender o alto 
nível de qualificação da mão de obra nos três pólos) confirmando a dimensão ontológica de criação do conhecimento de Nonaka e Takeuchi (1997).

A interação com clientes ficou evidenciada como um mecanismo de aprendizado bastante utilizado por parte das empresas desenvolvedoras de produtos customizados ou sob encomenda, nos três estudos realizados. As empresas de modo geral apontaram que a necessidade de atender aos requisitos demandados pelos clientes "força" as empresas a melhorarem seus produtos e processos desenvolvendo habilidades internamente e tornando-as na maioria dos casos específicos às firmas.

Todas as empresas do estudo foram unânimes em destacar a importância da proximidade com as instituições de ensino e serviços técnicos especializados para permanecerem localizadas em sua região, com a diferença de que em Blumenau a mão de obra qualificada está se tornando escassa (o que pode demonstrar uma provável deseconomia de aglomeração) e nos outros locais ela é abundante. Os alunos das instituições de ensino superior local têm atuado como multiplicadores do conhecimento sobre metodologias de melhorias de processo. Isto demonstra a importância em se criar uma interface maior com as empresas e criar canais e códigos de comunicação mais efetivos.

Com relação ao uso de fontes externas para ampliar as suas capacitações, em Campinas, as empresas não exploram as possibilidades existentes no arranjo para intensificar os fluxos e informação em melhoria de processos e qualidade. 0 arranjo possui duas importantes instituições de coordenação local voltadas aos interesses das empresas em melhoria de processos de software e qualidade, 0 Agente Regional SOFTEX e o Cenpra. As interações estabelecidas com estas instituições são pouco significativas. Não foi evidenciado na pesquisa ações conjuntas ou de cooperação das empresas que resultassem em mudanças técnicas construtoras de melhorias de processos.

Em Blumenau, a estrutura de conhecimento do arranjo encontra-se parcialmente desenvolvida, em estágio de desenvolvimento. As empresas menores sinalizam ainda estar se movendo mais pela lógica da rentabilidade dos negócios 
sem haver preocupação em inserir no rol das estratégias, ações voltadas a fazer da qualidade dos processo um instrumento competitivo. Já em Belo Horizonte, onde as MPME's representam $25 \%$ do total das empresas certificadas no Brasil, as empresas têm um bom nível de interação com instituições de classe e apoio local. São vários os agentes articulados e envolvidos tecnicamente numa ampla rede de cooperação para promover a difusão de conhecimento e aprendizado local, na qual a melhoria e qualidade de processos de software é uma das principais prioridades. Os serviços prestados pelas instituições estão baseados em diagnóstico das necessidades das empresas locais. O aprendizado por interação é fortemente estimulado pelos agentes de governança local.

Em síntese, em Campinas, as fontes de informações externas não têm sido utilizadas como instrumento potencializador da criação de capacitações locais. Esta constatação sinaliza o caráter limitado do arranjo em criar condições endógenas de produção e interação para a transferência de conhecimento e aprendizado local que resultem em vantagens competitivas para as empresas.

Em Blumenau, as fontes de informações externas relacionadas à melhoria de processos de software, (conferências, seminários, feiras, encontros informais de lazer e as reuniões promovidas pela associação empresarial), são sinalizadas pelas empresas como importantes mecanismos de aprendizado. A participação em feiras e eventos do setor colaboram para promover um ambiente cooperativo entre as firmas. Em Belo Horizonte, são várias as fontes de informações disponíveis e utilizadas pelas empresas que atuam como fatores potencializadores da criação de competências locais (cursos e treinamentos em melhorias de processos, feiras, eventos, participações em reuniões e comunidades de prática [SPIN -Software and Systems Process Improvement Network de Belo Horizonte] para disseminação de boas práticas em melhoria de processos de software), modelo cooperado de negócio (MPS.BR), que ampliam o learning by imitating corroborando o ambiente cooperativo entre as firmas. Neste arranjo, a presença de uma intensividade maior de processos de capacitação e aprendizagem é latente. A troca de informações entre os agentes, empresas, centros de capacitação (learning by interacting) com a frequência do learning bu doing tem sido fundamentais para colocar este arranjo num estágio de desenvolvimento superior aos demais. Percebe-se a gênese de um 
processo mais intenso de capacitação das empresas em qualidade e melhoria de processos, que demonstra maiores possibilidades de sucesso em menor espaço de tempo, auxiliado inequivocadamente por ações de políticas públicas locais, estaduais e federais.

Tratando-se de redes de cooperação interorganizacionais identificadas no estudo, as mais proeminentes e onde identificou-se a presença de relacionamento colaborativo foram: a rede de cooperação informal SPIN em BH e o Modelo Cooperado de Negócio MPS.BR. A tabela 5.3 apresenta uma síntese das fontes de informações utilizadas no aprendizado das empresas em melhoria de processos de software nos três estudos realizados.

1) Alunos, professores e cursos das universidades locais

2) Demandas dos clientes

3) Encontros informais de empresários para troca de informações

4) Feiras e Eventos

5) Área de produção da empresa (análise crítica de sucesso e fracassos de operações e projetos internos

6) Área de pesquisa e desenvolvimento

7) Internet

8) Consultoria em MPS - Agentes SOFTEX

9) Workshops para troca de experiências e lições aprendidas no âmbito de programas cooperados (MPS.BR)

10) Comunidades de Prática (Núcleo SPIN)

Tabela 5.3 - Síntese das fontes de informações utilizadas no aprendizado das empresas em melhoria de processos de software

Conforme Nakano (2005) os eixos e fatores do conhecimento transmitidos nas redes de conhecimento identificadas (Modelo Cooperado de Negócio - MBP.BR e Comunidade de Prática SPIN), possuem as seguintes características: parte significativa do conhecimento gerado é de natureza tácita, e exige canais de transmissão que possibilitem a interação, isto significa que na atividade de cooperação as empresas devem permanecer em rede. As empresas trocam 
conhecimento e aprendizado desde bastante simples, até conhecimentos mais complexos. A troca de conhecimento nesta rede é muito dependente de alguns fatores específicos, como objetivos de negócio, natureza da melhoria, competitividade entre as empresas. As empresas trocam sem problemas informações sobre ferramental utilizado nos processos de melhoria, sobre organização interna do pessoal, dificuldades na definição e implementação de processos, gerenciamento de projetos, capacitação interna do pessoal, adaptações da cultura organizacional (como as empresas institucionalizam os processos com baixo impacto na rotina de trabalho), estratégias de preparação para avaliações, entre outros. Porém, assuntos relacionados aos objetivos do negócio não costumam ser trocadas coletivamente, ou pelo menos não foi observado através da pesquisa. $A$ tabela 5.4 apresenta as principais vantagens e desvantagens do modelo cooperado de aprendizado das PME's apontadas pelos empresários.

Entretanto, isto não invalida a iniciativa do programa cooperado. As trocas de experiências e lições aprendidas no âmbito dos processos de aprendizado, com certeza possibilitam ganhos que não são fáceis de mensurar, como por exemplo, as empresas se auto avaliarem a partir da experiência dos participantes.

Em todos os pólos foi demonstrada a importância das fontes informais na geração de conhecimento, entretanto, apenas Belo Horizonte tem conseguido articular aprendizado coletivo através de redes de cooperação de conhecimento. Este pólo pode ser considerado como a principal referência de como o aprendizado com fontes externas de conhecimento pode ser gerado. A análise realizada encontra nas instituições de apoio como os principais protagonistas na promoção do aprendizado local e o poder público como coadjuvante neste processo. Tanto em Belo Horizonte como em Blumenau as instituições conhecem as principais necessidades das empresas e têm procurado atendê-las. No caso da participação do poder público nas ações de promoção ao desenvolvimento dos dois pólos, podese dizer que elas têm sido efetivas, mas podem ser potencializadas, sendo menos reativas e mais pró-ativas. 


\begin{tabular}{|c|c|}
\hline Vantagens & Desvantagens \\
\hline $\begin{array}{l}\text { 1) redução dos custos de implementação } \\
\text { e avaliação }\end{array}$ & $\begin{array}{l}\text { 1) necessidade de acompanhar } \\
\text { calendário de marcos coletivos previstos } \\
\text { em contrato, que às vezes não se } \\
\text { ajustam às necessidades das empresas }\end{array}$ \\
\hline $\begin{array}{l}\text { 2) as sanções ou penalidades do } \\
\text { programa forçam a dedicação das } \\
\text { empresas nos projetos de melhoria e no } \\
\text { planejamento coletivo }\end{array}$ & $\begin{array}{l}\text { 2) imprevistos nos projetos de melhoria } \\
\text { decorrentes do planejamento coletivo }\end{array}$ \\
\hline $\begin{array}{l}\text { 3) oportunidade para desenvolver outros } \\
\text { canais de comunicação entre as } \\
\text { empresas }\end{array}$ & $\begin{array}{l}\text { 3) sub-aproveitamento de oportunidade } \\
\text { de aprendizado e troca de experiências e } \\
\text { práticas (receio de perda de } \\
\text { competitividade por parte das empresas e } \\
\text { falta de maior articulação por parte dos } \\
\text { mediadores) }\end{array}$ \\
\hline $\begin{array}{l}\text { 4) possibilita e potencializa a combinação } \\
\text { de diferentes tipos de conhecimentos }\end{array}$ & \\
\hline $\begin{array}{l}\text { 5) oportuniza a geração de novos } \\
\text { negócios }\end{array}$ & \\
\hline $\begin{array}{l}\text { 6) oportuniza a observação mútua do } \\
\text { desenvolvimento e dificuldades das } \\
\text { empresas }\end{array}$ & \\
\hline
\end{tabular}

Tabela 5.4 - Principais vantagens e desvantagens do modelo cooperado de aprendizado das PME's

Estas considerações podem ser complementadas com a análise de elementos do capital social local, como a cooperação e a confiança que foram construídos ao longo do tempo, como no caso de Blumenau, e fomentados no caso de Belo Horizonte. Já em Campinas a baixa cooperação observada pode ser reflexo de uma cultura perdida com as reformas estruturais do pólo na década de 90 ou de uma postura mais individualista das empresas desenvolvida a partir dos mesmos eventos. 
O estudo realizado é convergente à afirmação de Humphrey e Schmitz (1998) de que a provisão de agentes de coordenação e mediação é crucial para o processo de funcionamento das redes, colaborando para superar a desconfiança através da promoção de ações conjuntas.

Concluindo a análise a respeito do conhecimento e aprendizado nos APL's estudados, a tabela 5.5 apresenta uma síntese das principais questões de pesquisa desta tese que foram analisadas no estudo presente. 


\begin{tabular}{|c|c|c|c|}
\hline $\begin{array}{l}\text { Questões Relevantes do } \\
\text { Estudo }\end{array}$ & Campinas & Belo Horizonte & Blumenau \\
\hline $\begin{array}{l}\text { 1) Mecanismos e processos } \\
\text { de aprendizado }\end{array}$ & $\begin{array}{l}\text { Informal } \\
\text { Learning by } \\
\text { doind/using } \\
\text { Learning by } \\
\text { interaction }\end{array}$ & $\begin{array}{l}\text { Informal } \\
\text { Formal } \\
\text { Learning by } \\
\text { doind/using } \\
\text { Learning by } \\
\text { interaction }\end{array}$ & $\begin{array}{l}\text { Learning by } \\
\text { doind/using } \\
\text { Learning by } \\
\text { interaction }\end{array}$ \\
\hline $\begin{array}{l}\text { 2) Fontes externas de } \\
\text { conhecimento }\end{array}$ & $\begin{array}{c}\text { Clientes } \\
\text { Instituições de } \\
\text { ensino local } \\
\text { Interação }\end{array}$ & $\begin{array}{c}\text { Clientes, Cursos, } \\
\text { treinamentos em } \\
\text { melhorias de } \\
\text { processos, feiras, } \\
\text { eventos, } \\
\text { participações em } \\
\text { reuniões e } \\
\text { comunidades de } \\
\text { prática, atividades } \\
\text { das entidades de } \\
\text { apoio, modelo } \\
\text { cooperado de } \\
\text { negócio (MPS.BR } \\
\text { Interação } \\
\text { Cooperação }\end{array}$ & $\begin{array}{c}\text { Clientes, } \\
\text { conferências, } \\
\text { seminários, feiras, } \\
\text { encontros informais } \\
\text { de lazer e as } \\
\text { reuniões } \\
\text { promovidas pela } \\
\text { associação } \\
\text { empresarial, } \\
\text { Instituições de } \\
\text { ensino local } \\
\text { Interação } \\
\text { Interação }\end{array}$ \\
\hline $\begin{array}{ll}\text { 3) Processo } & \text { de } \\
\text { transferência/difusão } & \text { do } \\
\text { conhecimento } & \end{array}$ & $\begin{array}{c}\text { Tácito } \\
\text { Restrita infra- } \\
\text { estrutura } \\
\text { facilitadora do } \\
\text { intercâmbio de } \\
\text { informações } \\
\text { Redes horizontais } \\
\text { informais }\end{array}$ & $\begin{array}{c}\text { Tácito } \\
\text { Explícito } \\
\text { Ampla infra- } \\
\text { estrutura facilitadora } \\
\text { do intercâmbio de } \\
\text { informações } \\
\text { Redes horizontais } \\
\text { informais }\end{array}$ & $\begin{array}{c}\text { Tácito } \\
\text { Restrita infra- } \\
\text { estrutura facilitadora } \\
\text { do intercâmbio de } \\
\text { informações (em } \\
\text { desenvolvimento) } \\
\text { Redes horizontais } \\
\text { informais }\end{array}$ \\
\hline
\end{tabular}




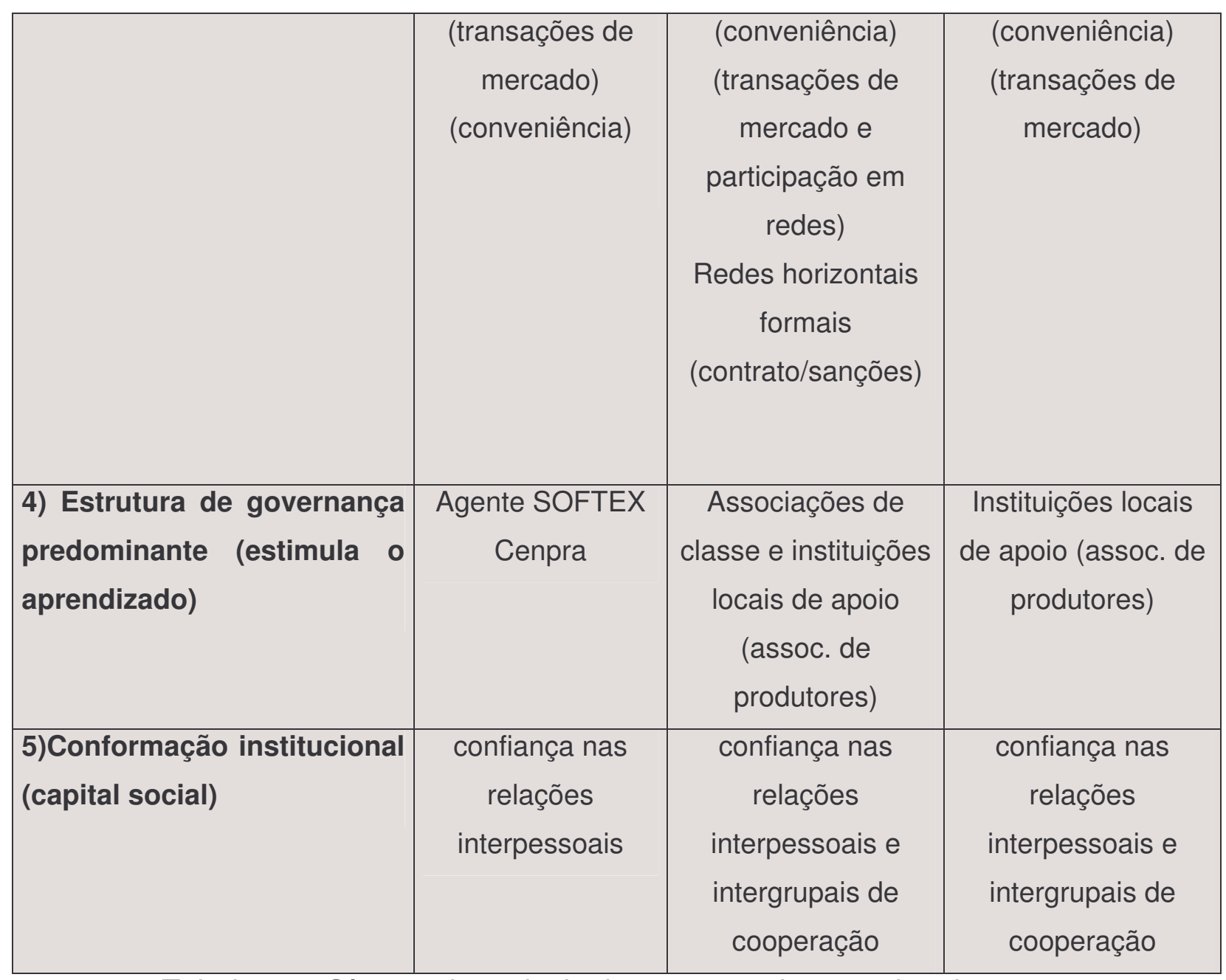

Tabela 5.5- Síntese das principais questões de pesquisa da tese 


\section{CONCLUSÕES DA PESQUISA}

Este trabalho contribuiu para o entendimento da dinâmica de aprendizagem em APL's de empresas de software. $O$ foco principal recaiu em como as pequenas e médias empresas constroem suas capacitações a partir de interações e cooperações com fontes externas de conhecimento, essenciais ao processo de geração de inovações das empresas.

A motivação principal para a escolha do tema decorreu do reconhecimento de que o conhecimento e a aprendizagem, ambos possuem papel central na construção de novas competências para a obtenção de vantagens competitivas.

Para alcançar o objetivo principal proposto, foram identificados e avaliados os mecanismos de aprendizado disponíveis em âmbito local nos pólos de software, que contribuem para o incremento ou a redução de assimetrias de conhecimento. Redes de conhecimento informal tal como as Comunidades de Prática têm demonstrado ser bastante atraentes na promoção do conhecimento coletivo e na geração de aprendizado.

Os resultados da pesquisa corroboram com a proposição de que os processos de aprendizagem por interação e cooperação são determinantes para as PME's de software na construção de conhecimentos e geração de capacitações inovativas.

O aprendizado das empresas pode estar baseado num modelo de organização da produção onde o território é aspecto de suma importância para a integração das empresas, ou seja, a proximidade geográfica favorece a geração e a difusão de conhecimento.

A compreensão do fenômeno da geração do conhecimento e aprendizado apontou para um processo dinâmico através do qual as empresas recorrem a 
diferentes fontes de conhecimento, evidenciando o conhecimento externo, como sendo de caráter essencial no processo de geração de conhecimentos.

O presente estudo evidencia a importância de uma estrutura de governança articulada que possa promover e fomentar um sistema de conhecimento local. Torna-se essencial para a capacitação das empresas e o desenvolvimento competitivos de um APL um arcabouço institucional que aponte no sentido de promover a interação e a cooperação criando competências locais dinâmicas. Dentre elas destacam-se os programas de aprendizado cooperado de empresas em melhoria de processos de software e as redes de conhecimento através das comunidades de prática, a geração de estímulo para o desenvolvimento de ações cooperativas.

As ações conjuntas nas concentrações de empresas dependem da existência de formas de governança ou coordenação do local que estimulem a manutenção de relações cooperativas entre os agentes, estimulando a competitividade do conjunto de produtores.

Com base nisto, a pesquisa identificou os tipos de conformações institucionais de APLS de software que são mais capazes de promover a geração de conhecimento e aprendizado local.

As diversas relações com outras firmas e organizações estabelecem formas diversas de aprendizagem por interação. A compreensão da dinâmica destas formas está relacionada às possibilidades de transferência de informações e conhecimentos e as especificidades da dinâmica de inovação. Dado o caráter fortemente tácito do conhecimento no aprendizado das empresas desenvolvedoras de software, percebese a importância das interações no aprendizado dessas empresas.

O modelo cooperado de negócio para aprendizagem das empresas em qualidade e melhoria de processos, apesar de algumas limitações, tem-se mostrado eficiente no sentido de gerar especificidades de conhecimentos e disseminar a cultura da cooperação local. 
Sem a pretensão de querer fazer apologia à qualquer metodologia de melhoria de processos de software, é importante reconhecer que o MPS.BR é uma iniciativa que tem dado certo. O programa tem treinado e capacitado cerca de 3000 pessoas desde junho de 2004. Quase 900 pessoas já foram habilitadas a realizarem implementações e até o final de 2007, 120 empresas implementaram o programa, sendo 93 delas no Modelo de Negócio Cooperado.

Sobre isto, a pesquisa identificou fatores condicionantes à troca de conhecimentos e aprendizado em ambiente de cooperação: como os objetivos do negócio, a natureza da melhoria e a competitividade das empresas. Tais fatores são importantes para compreender como as Instituições podem gerir os processos cooperados procurando ampliar e melhorar os fluxos e canais de informação entre os agentes.

A pesquisa também serve para reafirmar a importância das inovações, sejam elas radicais ou incrementais, para a obtenção de vantagens competitivas. Como contribuição teórica, o presente estudo vem somar-se ao conhecimento da dinâmica de aprendizado das empresas intensivas de software na construção de suas capacitações.

Este trabalho proporcionou entre outras coisas perceber que a indústria de software constitui-se um campo de estudo em si, dada a sua singularidade, apresentando uma configuração bastante complexa. A atividade produtiva de software é bastante heterogênea, com diversas funções e intensidades tecnológicas variadas. Atividades de menor intensidade tecnológica como testes, manutenção de banco de dados ou programação envolvem conhecimentos mais simples, codificáveis (explícitos) e as atividades mais complexas, de maior intensidade tecnológica e valor agregado, vão exigir conhecimentos implícitos ou tácitos que demandam maior contato com clientes e usuários.

Com a clara divisão internacional da atividade produtiva de software, como ocorre em diversos setores da economia, comandada por grandes empresas globais que direcionam as funções hierarquicamente inferiores do processo produtivo à 
países periféricos, como o Brasil, investir em atividades hierarquicamente superiores e de maior valor tecnológico e inovativo, bem como em segmentos mais estratégicos e relevantes onde as barreiras de entrada são maiores são determinantes para diminuir as assimetrias de conhecimento e dependência tecnológica, são importantes para aumentar a competitividade das empresas nacionais.

Para isso, são importantes as políticas públicas que privilegiem ações de promoção e fomento à geração e difusão de conhecimento e desenvolvimento de mecanismos de aprendizado, a exemplo do MPS.BR.

Os resultados da pesquisa corroboram com a proposição de que os processos de aprendizagem por interação são determinantes para as PME's de software na construção de conhecimentos e geração de capacitações inovativas.

O presente estudo evidencia a importância de uma estrutura de governança articulada que possa promover e fomentar um sistema de conhecimento local. Torna-se essencial para a capacitação das empresas e o desenvolvimento competitivos de um APL um arcabouço institucional que aponte no sentido de promover a interação e a cooperação criando competências locais dinâmicas. Dentre elas destacam-se os programas de aprendizado cooperado de empresas em melhoria de processos de software e as redes de conhecimento através das comunidades de prática, a geração de estímulo para o desenvolvimento de ações cooperativas.

Finalizando, é fundamental reconhecer a dificuldade inerente à sintese de resultados empíricos, que impõem limites à pesquisa científica, sobretudo quando há diversidade de realidade e amostra reduzida. Esta pesquisa, esteve mais relacionada à análise estrutural dos arranjos, de forma que desdobramentos deste trabalho poderiam ser voltados:

- para um entendimento mais detalhado das interações das empresas entre clientes, fornecedores, concorrentes e fontes internas; 
- comparar e ampliar o estudo sobre a transferência do conhecimento dentro de outros modelos cooperados de aprendizado em outras localidades; 


\section{REFERÊNCIAS BIBLIOGRÁFICAS}

ABNT, (2000). NBR ISO 9000:2000 - Sistemas de Gestão da Qualidade Fundamentos e Vocabulário. Associação Brasileira de Normas Técnicas, Rio de Janeiro.

ALBAGLI, S; MACIEL, M.L. (2002). Capital Social e Empreendorismo Local. In: Proposição de Políticas para a Promoção de Sistemas Produtivos Locais de Micro, Pequenas e Médias Empresas. Disponível em: www.ie.ufri.br/redesist. Acesso em: 05/05/05

ANDRIANI, P. et al. (2005) Challenging Clusters - The Prospects and Pitfalls of Clustering for Innovation and Economic Development. Summary Report from AIM Management Research Forum in cooperation with the Welsh Economy Research Unit. Advanced Institute of Management Research, June, 2005.

ASSOCIAÇÃO BRASILEIRA DE EMPRESAS DE SOFTWARE (2006). Mercado Brasileiro de Software - Panorama e Tendências.

AMATO NETO, J. (2000). Redes de cooperação produtiva e clusters regionais: oportunidades para as pequenas e médias empresas. São Paulo: Atlas: Fundação Vanzolini.

AMATO NETO, J. (2005). Redes dinâmicas de cooperação e organizações virtuais. In: AMATO NETO, J. (org) Redes entre organizações: domínio do conhecimento e da eficácia operacional. São Paulo: Atlas.

AMIN, A; COHENDET, P. (2004). Architectures of Knowledge. Firms, Capabilities and Communities. Oxford: Oxford University Press.

ARROW, K. (1962). The Economic Implications of Learning-by-doing. The Review of Economic Studies. Vol. 29, n.03, pp. 155-173.

ASHEIM, B.T.; COOLE, P. (1997). Localised innovation networks in a global economy: a comparative analysis of edogenous and exogenous regional development approache. In: IGU COMMISSION ON THE ORGANISATION OF INDUSTRIAL SPACE RESIDENTIAL CONFERENCE, Gothenburg, Sweden, Aug.

AUN, M. P.; CARVALHO, A.M.A.; KROEFF, R. L. (200?). Aprendizagem coletiva em arranjos produtivos locais: um novo ponto para as políticas públicas de informação.

AUSTIN, J. (2001). Parcerias: fundamentos e benefícios para o terceiro setor. SP: Futura.

BALESTRIN, A.; VARGAS, L. M. (2004) A dimensão estratégica das redes horizontais de PME's: teorizações e evidências. Revista de Administração Contemporânea, Edição Especial. 
BECATTINI, G. (1989). II distreto industriale come ambiente criativo. In: E. Benedetti (éd.), Mutazione Tecnologiche e Condizionamenti Internazionali. Milão: Franco Angeli.

, G. (1979). Dal settore industrialle all distretto industrialle: alla ricerca dell'únitá di indagine della economia industriale. Rivista di Economia e Politica Industriale, n.1.

(1990). The Marshallian industrial district as a socio-economic notion. In: F. Pyke, F. Becattini e W. Sengenberger (orgs), Industrial Districts and Inter-firm Cooperation in Italy. Gênova: International Institute for Labour Studies.

(1998). Distretti Industriali Made in Italy. Torino: Bollati. Boringhieri.

BELLINGER, G. (2002). Knowledge Management: emerging thoughts, [online] disponível em http://www.outsights.com/systems/kmgmt.htm. Acesso em 08 de janeiro de 2006.

BERKOVICH, N.; SCHWANKE, C. (2005). Cooperação e Competitividade na Indústria de Blumenau. Revista de Negócio. Blumenau, v.10, n.4, p.302-319. out/dez.

(1998). Distretti Industrialli e Made in Italy. Torino: Bolatti Boringhieri. BOLLINGER, L.; HOPE, K.;UTTERBACK, J. M. (1983). A review of literature and hypotheses on new technology-based firms. Research Police, v. 12, p. 1-14.

BLUSOFT (2007). O pólo de software de Blumenau.

BOURDIEU, A. (2004). O capital social. In: NOGUEIRA, M. A.; CATANI, A. (Orgs) Pierre Bourdieu: escritos de educação. Petrópolis: Vozes, p.65-69.

BREMER, C. F.; CORREA, G. N.; (2001). Organizações e empresas virtuais: conceitos e aplicações. In: AMATO NETO, J.;(Org.) Manufatura de classe mundial: conceitos, estratégias e aplicações. São Paulo: Atlas, Cap. 7, p. 146-176.

BRESCHI, S.; MALERBA, F. (1997). Sectorial innovation systems: technological regimes, schumpeterian dynamics, and spatial boundaries. In : EDQUIST, C. (ed.) Systems of innovation technologies, institutions and organizations. London: Pinter, UK, p.130-156.

BRITTO, J, (2002). Cooperação interindustrial e redes de empresas. IN: KUPER, D.; HASENCLEVER, L. (Org.). Economia industrial, fundamentos teóricos e práticas no Brasil. Rio de Janeiro: Campus.

BRUSCO, S. (1990). The idea of the industrial district: its genesis. In: F. Pyke, G. Becattini, W. Sengenberger (eds), Industrial Districts and Inter-firm Cooperation in Italy. Gêneva: International Institute for Labour Studies, ILO.

BRYMAN, A. (1989). Research methods and organization studies. London: Unwin Hyman, London. 
CAMPOS, R.R. et. al.(2002). Aprendizagem por interação: pequenas empresas em sistemas produtivos e inovativos locais. UFRJ: RedeSist. (Texto do Projeto Proposição de Políticas para a Promoção de Sistemas Produtivos Locais de Micro, Pequenas e Médias Empresas Brasileiras). Disponível em: http://www.sinal.redesist.ie.ufri.br/nts.nt33F22 Renato.pdf http://www.sinal.redesist.ie.ufrj.br/nts.nt33F22 Renato.pdf. Acesso em15/07/2006.

CÂNDIDO, G. A.;ABREU, A. F. (2000). Os conceitos de redes e as relações interorganizacionais: um estudo exploratório. In: ENANPAD, 24. Florianópolis: ANPAD. CD.

CASAROTTO FILHO, N.; PIRES, L. H. (2001). Redes de Pequenas e Médias Empresas e Desenvolvimento Local: estratégias para a conquista da competitividade local com base na experiência italiana. São Paulo: Ed. Atlas, 2001.

CASSIOLATO, J. E.; SZAPIRO, M. (2002). Arranjos e sistemas produtivos e inovativos locais no Brasil. Rio de Janeiro: Instituto de Economia da UFRJ, p.34. (2003). Uma caracterização de arranjos produtivos locais de micro e pequenos empresas. In: Lastres, H. M. M., Cassiolato, J. E., Maciel, M. L. Pequena empresa: cooperação e desenvolvimento local. Rio de Janeiro, Relume Dumará.

CASSIOLATO, J. E.; LASTRES, H. M. M. (2003). O foco em arranjos produtivos e inovativos locais de micro e pequenas empresas. In: CASSIOLATO, J.E.; LASTRES, H.M.M.; MACIEL, M. L. (Orgs.) Pequena Empresa: cooperação e desenvolvimento local. Rio de Janeiro: Relume Dumará, p.21-34.

(1999). Globalização e inovação localizada: experiências de sistemas locais no Mercosul. Brasília: IBICT/IEL.

CASTELS, M. (1999) A Sociedade em Rede. Paz e Terra. São Paulo.

CEGLIE, G.; DINI, M. (1999). SME cluster and network development in developing countries the experience of UNIDO. In: INTERNATIONAL CONFERENCE ON BUILDING A MODERN AND EFFECTIVE DEVELOPMENT SERVICE INDUSTRY FOR SMALL ENTERPRISESORGANIZED, Rio de Janeiro. Disponível em: http:www.ilo.org;public;engish;employment;papers;clusters.htm. acesso em 07 de set. 2004.

CERVO, A. L.; BERVIAN, P. A. (2002). A metodologia científica. São Paulo: Pearson Prentice Hall.

CMU/SEI - Carnegie Mellon University / Software Engineering Institute (2000a). Capability Maturity Model Integration, Pittsburg. Disponível em: http://www.sei.cmu.edu/cmmi. Acesso em: 10 de outubro de 2007.

CMU/SEI - Carnegie Mellon University / Software Engineering Institute (2000b). Capability Maturity Model Integration, Version 1.1. CMMI-SE/SW/IPPD/SS. Disponível em: http://www.sei.cmu.edu/cmmi/models. Acesso em: 10 de outubro de 2007. 
CORAL et al. (2007). Tecnologia da informação e comunicação. Florianópolis: Instituto Euvaldo Lodi, 326p.

CORNO, F.; REINMOELLER, P.; NONAKA, I. (1999). Knowledge creation within industrial systems. Journal of Management and Governance. v.3, p.379-394.

CORRÊA, G. N. (1999). Proposta de integração de parceiros na formação e gerência de empresas virtuais. Tese de Doutorado. Escola de Engenharia de São Carlos, São Carlos.

COUTINHO, L.; FERRAZ, J. C (1995). Estudo da competitividade da indústria brasileira. $3^{\mathrm{a}}$ ed. Campinas: Papirus. Editora da Universidade Estadual de Campinas.

CHRISSIS, M. B.; KONRAD, M.; SHRUM, S. (2003). CMMI Guidelines or Process Integration and Product Improvement, Addison Wesley Longman, Inc., Massachussets.

CRESWELL, J. W. (1994). Research design: qualitative and quantitative approaches: Thousand Oaks, CA, Sage. (2003). Qualitative, quantitative and mixed methods approaches.

Thousand Oaks, CA: Sage.

DAVENPORT, T.; PRUSAK, L. (1998). Working knowledge: how organizations manage what they know, Boston: Harvard Business School Press, 1998.

DEGENNE, A. (2004). Resenha de Nan Lin. Social capital: a theory of social structure and action. Tempo Social, Revista de Sociologia da USP, São Paulo, v.16, n.2, p.303-305.

DIEGUES JR.; A.; C. (2004). Um estudo das atividades de software desenvolvidas no pólo de tecnologia de informação e comunicação da região de Campinas, TCC Unicamp, dez.

DIEGUES JR.; A. C.; ROSELINO, J. E. (2006). Interação, aprendizado tecnológico e inovativo no Pólo de TIC da Região de Campinas: uma caracterização com ênfase nas atividades tecnológicas desenvolvidas pelas empresas beneficiárias da Lei de Informática. Revista Brasileira de Inovação. V.5. oㅡ 2. jul/dez.

DOGSON, M. (1996). Learning trust and inter-firm technological linkages: some theoretical associations. In COOMBS, R. RICHARDS, A. SAVIOTTI, P. P; WALSH, V. Technological Collaboration: The Dinamics of cooperatio in industrial innovation. Edward Elgar, Cheltenham, UK, 1996.

DYER, J.H.; NOBEOKA, K. (2000). Creating and managing a high-performance knowledge-charing network: the Toyota case. Strategic Management Journal. V.21, p.345-367.

DOSI, G. (1988). Sources, procedures and microeconomic effects of innovation. Journal of Economic Literature, vol. 26, n.3. 
DOSI, G.; MALERBA, F. (1996). Organizational learning and institutional embeddedness. In: DOSI, G. ; MALLERBA, F. Organization and strategy in the evolution of the enterprise. London: Macmillan Press.

DUARTE, L. S. (2003). Caracterização da inovação tecnológica no setor de software de gestão integrada: estudos de casos nas empresas de base tecnológica do Estado de São Paulo. Dissertação de Mestrado. Instituto de Economia. UNICAMP. Campinas.

EBERS, M.; JARILLO, J. C. (1998). The construction, forms, and consequences of industry networks. International Studies of Management and Organization, v.27, p.321, Winter, 1998.

EDQUIST. C. (1997). Systems of innovation approaches: their emergence and characteristics. In: EDQUIST, C. (ed). Systems of innovation: technologies, institutions, and organizations. London, Pinter.

ENDERLE, R. A.; CÁRIO, S. A. F.; NICOLAU, J. A. (2005). Estudo do arranjo produtivo local madeireiro do vale do Iguaçu (PR/SC): capacitação tecnológica e política de desenvolvimento. Revista Paranaense de Desenvolvimento. Curitiba, n.108, p. 113-141, jan./jun.

ERNST, D. (1994). Inter-firm networks and market structure: driving forces, barriers and patterns of controll.CA: University of California.

EUROPEAN COMMISSION (2002). Final Report of the Expert Group on Enterprise Cluster and Networks. European Commission - Enterprise Directorate - General. Disponível em:

http://.ec.europa.eu/enterprise/entrepreneurship/support measures/cluster/final repo rt clusters en.pdf/

http://ec.europa.eu/enterprise/entrepreneurship/support measures/cluster/map proje ct.htm. Acesso em 02 de outubro de 2007.

EUROPEAN COMMISSION (2002a). Observatory of European SMES, 2002/No 3 Regional clusters in Europe, Report Submitted to the Enterprise Directorate General by KPMG Special Services, EIMB Business \& Policy Research, and ENSR, Luxembourg, Office for Officcial Publications of the European Communities. Disponível em: http://.ec.europa.eu/enterprise/entreprise-policy/analysis/doc/smesobservatory-2002-report-en-pdf. Acesso em 02 de outubro de 2007.

EUROPEAN COMISSION (2004). Observatory of European SMEs 2003, No.5 SMEs and cooperation. Disponível em http://ec.europa.eu/enterprise/enterprise_police/analysis/observatory_en.htm. Acesso em 02 de outubro de 2007.

FAGGION, G. A; BALESTRIN, A.;WEYH, C. (2002). Geração de conhecimento e inteligência estratégica no universo das redes interorganizacionais. Revista Inteligência Empresarial, n.12, p. 55-65, julho de 2002. 
FARINELLI, F.; MITELKA, L. (2000) Local clusters, innovation systems and sustained competitiveness. Disponível em http://www.ie.ufri.br Acesso em 20/06/06

FAYARD, P. (2000). O jogo da interação: informação e comunicação em estratégia. Caxias do Sul: EDUCS.

FEIGENBAUN, N. E. (1991). Total Quality Control . McGraw-Hill International Editors, 3th., ed.,New York.

FERRARI, F.M.; MARTINELLI, D. P.; JOYAL, A. (1999). Uso da informação e capacidade de inovação das PME brasileiras. Anais do II SIMPOI, São Paulo. CD?

FERREIRA JR.; H. M.; SANTOS, L. D. (2006). Sistemas e arranjos produtivos locais: o caso do pólo de informática de Ilhéus (BA). Revista de Economia Contemporânea. Rio de Janeiro, 10 (2): 411-442, mai./ago.

FLEURY, A.; FLEURY, M.T.L. (2005). A arquitetura das redes empresariais como função do domínio de conhecimentos. In: AMATO, J. (org) Redes entre organizações: domínio do conhecimento e da eficácia operacional. São Paulo, Atlas.

FLEURY, A. L. (2007). Alinhando objetivos estratégicos e processo de desenvolvimento em empresas de software. 203p. Tese de Doutorado. Escola Politécnica. Universidade de São Paulo.

FLORIAN, F. (2005). APL's: formação, desenvolvimento e vínculos nas Indústrias de "Bordado de Ibitinga-SP. Dissertação de Mestrado. UNIARA. Araraquara.

FREEMAN, C. (1995). The National System of innovation in historical perspective. Cambridge Journal of Economics.

(1987). Technology and Economic Performance: Lessons from Japan. Londres: Pinter Publishers.

FREIRE, E. (2002). Inovação e competitividade: o desafio a ser enfrentado pela indústria de software. Dissertação de Mestrado. Campinas, SP.

FUGETTA, A. (2000). Software Process: A Roadmap. IN: The Future of Software Engineering 2000, Procedings of the 22 International Conference on Software Engineering. p 27-34. Ed. Anthony Fiukelstein - The Association for Computing Machinery (ACM) New York.

FUKUYAMA, F. (2000). A grande ruptura. Rio de Janeiro, 2000, 344 p.

FUMSOFT (2007). A visão de futuro em TI e as competências necessárias à competitividade, versão beta.

FURTADO, J. (2003). Cadeias produtivas globalizadas: a emergência de um sistema de produção integrado hierarquicamente no plano internacional. In : FURTADO, J. (org.), Globalização das cadeias produtivas do Brasil, EdUFSCAR. 
GALVÃO, A.P.; COCCO, G. (1999). Desenvolvimento Local e Espaço Público: Questões para a Realidade Brasileira. Revista RECITEC. Recife, v. 3, p. 145-158.

GARCIA, R. (2001). Vantagens competitivas de empresas em aglomerações industriais: um estudo aplicado à indústria brasileira de calçados e sua inserção nas cadeias produtivas globais. Tese de Doutorado. Instituto de Economia, Unicamp.

GARCIA, R.; ROSELINO, J. E. (2004). Uma avaliação da Lei de Informática e seus resultados como instrumento indutor de desenvolvimento tecnológico e industrial. Gestão \& Produção, São Carlos, v.11, n.2, p.1-20.

GEREFFI, G. (1994). The organization of buyer-driven global commodity chains: how U. S. retailers shape overseas production networks. In: GEREFFI, G.; KORZENIEWICZ, M. (eds) Commodity Chain and Global Capitalism. Praeger: Westport, p. 95-122.

(1998). Competitividade e redes na cadeia produtiva do vestuário na América do Norte. Revista Latino-Americana de Estudos do trabalho, v.4, n.6, p.101127.

GERTLER, M. S. (2001). Tacit Knowledge and the Economic Geography of Context. Department of Geography and Program on Globalization and Regional innovation Systems, Centre for International Studies University of Toronto. DRUID Conference, Aalborg, june 12-15.

GIL, A. C. (1996). Como elaborar projetos de pesquisa. Ed. Atlas, 3. Ed., São Paulo.

GOLDMAN, S.; NAGEL, R.; PREISSK, K. (1995). Agile competitors: concorrência e organizações virtuais. São Paulo: Érica.

GONÇALVES, E.; GAVIO, F. P. H. (2002). Capacidade de inovação regional: o papel de instituições e empresas de base tecnológica em Juiz de Fora. Revista Nova Economia. Belo Horizonte, v.12, p. 89-115. Jan./jun.

GONSALVES, E. P. (2001). Conversas sobre iniciação científica. Campinas, SP: Editora Alínea.

GOVERNO FEDERAL (2003). Diretrizes de Política Industrial, Tecnológica e de Comércio Exterior. Disponível em:

http://www.abdi.com.br/abdi redesign/publicacao/download.wsp?tmp.arquivo=107. Data de acesso: 05/04/07.

GRANDORI, A.; SODA, G. (1995) Inter Firm Networks: antecedents, mechanism and forms. Organization Studies.16/2.

GRANT, R. M. (1996). Toward a knowledge-based theory of the firm. Strategic Management Journal, v.17, p.109-122 
GUIMARÃES, V. (2005). Sistemas de inovação em países periféricos: o arranjo produtivo das empresas de software em Petrópolis. Dissertação de mestrado. Universidade Federal do Rio de Janeiro.

HEEKS, R.; NICHOLSON, B. (2002). Software export success factors and strategies in developing and transitional economies. Paper no 12/2002. Disponível em: http://www.man.ac.uk/idpm/idpm dp.htm\#devinf wp. Acesso em: 10/04/2006.

HOPE, J.; HOPE, T. (2000), Competindo na terceira onda: os dez mandamentos da era da informação. Rio de Janeiro: Campus, 2000.

HUMPHREY, J. (2003). Opportunities for SME's in developing countries to upgrade in a global econonmy, working paper No. 43, International Labour Office, Geneva, 2003.

HULSINK, W.;ELFRING, T. (2003).. Networks effects on Entrepreneurial Processes: Start-ups in the Dutch ICT Industry 1990-2000. Paper presented at the American Sociological Association 2003 Annual Meeting, Regular Session on Organizational Foundings, Atlanta GA, August 16-19, 2003. Disponível em:

<https://dspace.ubib.eur.nl/retrieve/1784/ASA+2003+Elfring+Hulsink+paper.pdf> Acesso em: 12 dez 2007.

HUMPHREY, J. \& SCHMITZ, H.(1998). Trust and Interfirm Relations in Developing and Transition Economies. Journal of development Studies, vol.34, n.4, pp. 32-61.

(2000). Governance and upgrading: linking industrial cluster and global value chain research. Working Paper, Brighton: Institute of Development Studies, University of Susssex.

IGLIORI, D. C.(2001). Economia dos clusters industriais e desenvolvimento. São Paulo : FAPESP.

ISO, 1995, ISO/IEC 12207:1995 - Information Technology - Software life cicle processes. International Organization for Standardization, Montreal.

JOHNSON, B; LUNDVALL, B. (1992) Closing the institutional gap? Revue d'Economie Industrielle, n.59, 1 er trimestre.

23-42, dec.

(1994). The learning economy. Journal of Industry Studies, vol. 1, n.2, p.

JOHNSON, B.; LUNDVALL, B. (2000). Promoting Innovation Systems as a Response to the Globalizing Learning Economy. In: Cassiolato, J, et al. Arranjos e Sistemas Produtivos Locais e as Novas Políticas de Desenvolvimento Industrial e Tecnológico. Rio de Janeiro: IE/UFRJ. Contrato BNDES/FINEP-FUJB.

JULIEN, P.A. (1997). Les PME: bilan et perspectives. 2. ed.Québec. Les Presses InteerUniversitaires. Cap. 1, p.19-39. 
KOCH, W. (1998). Arquitetura dos sistemas. Mundo da imagem. CENADEM, n. 25, jan-fev.

KOCK, N. (1999). Process Improvement and Organizational Learning: the role of collaboration technologies, Hershey: Idea Group Publishing, 1999.

KOGUT, B; ZANDER, U. (1992). Knowledge of the firm, combinative capabilities, and the replication of technology. Organisation Science, v.3, p.383-397,

KUBOTA, L. C. (2006). Desafios para a indústria de software. Texto para Discussão no 1150. Instituto de Pesquisa Econômica Aplicada. Ministério do Planejamento, Orçamento e Gestão. Disponível em: http://www.ipea.gov.br. Data de acesso:02/06/07.

KRUGLIANSKAS, I. (1996). Tornando a pequena e média empresa competitiva. São Paulo: Instituto de Estudos Gerenciais e Editora.

KRUGMAN, P. (1998). What's new about the New Economic Geography? Oxford Review of Economic Policy, v.14, n.2.

(1991). Geography and Trade. Cambridge, MA:MIT Press.

MIT Press.

(1995) Development, Geography and Economic Theory. Cambridge, MA:

(1999). National Systems of Innovation : Towards a theory of innovation and interactive learning. Londres: Pinter.

LAM. A (2000). Tacit Knowledge , Organizational Learning and Societal Institutions. An integrated Framework. Organizaional Studies. vol 21, n.03, p. 487-513.

LA ROVERE, R. L.; CARVALHO, R. L. (2004). Cooperação entre pequenas empresas e desenvolvimento local. In: Conferência Internacional sobre Empreendedorismo. CEPAL. Rio de Janeiro.

LASTRES, H. M.M.; CASSIOLATO, J. E.(2004). Glossário de arranjos e sistemas produtivos e inovativos locais. In : Arranjos produtivos locais: uma nova estratégia de ação para o SEBRAE. Disponível em www.ie.ufri.br/redesist Acesso em 10/02/06.

LASTRES, H. M.M.; ARROIO, A.; LEMOS, C.(2003). Políticas de apoio a pequenas empresas: do leito de Procusto à promoção de sistemas produtivos locais. In:

LASTRES, H. M.M.; CASSIOLATO, J. E.; MACIEL, M. L. Pequena empresa: cooperação e desenvolvimento local. Rio de Janeiro: Relume Dumará.

LASTRES, H. M. M. (2004). Indicadores da era do conhecimento: pautando novas políticas na América Latina. Seminário 15 a 17 de setembro de 2004.

LATEEF, A. (2003). Linking up with the global economy: a case study of the Bangalore software industry. Disponível em: 
http://www.ilo.org/public/english/bureau/inst/papers/1997/dp96/index.htm\#toc.

Acesso em: 10/04/06.

LEI, D. J.; SLOCUM, W. (1992). Global strategy, competence building and strategic alliances, California Management Review, n.35, vol.1, p. 81-97, 1992.

LEMOS, C. R. (2003). Micro, pequenas e médias empresas no Brasil : novos requerimentos de políticas para a promoção de sistemas produtivos locais. Rio de Janeiro. Tese Doutorado. COOPE - Universidade Federal do Rio de Janeiro.

LEON, M. H. (1998). Uma análise de Redes de Cooperação das Pequenas e Médias Empresas do Setor das Telecomunicações. Dissertação de Mestrado, Engenharia de Produção da Escola Politécnica da Universidade de São Paulo, Dez.

LEON OLAVE, M. H.; AMATO NETO, J. (2001). Redes de Cooperação Produtiva: uma estratégia de competitividade e sobrevivência para pequenas e médias empresas. Gestão e Produção, v.8, n.3, p.289-303, dez., 2001.

LEON OLAVE, M. H. (2003). As PME's de automação industrial na dinâmica empresarial: possibilidades de formação de redes de cooperação no Estado de São Paulo. Tese de Doutorado. Universidade de São Paulo. Departamento de Engenharia de Produção.

LEON OLAVE, M. H.; AMATO NETO, J.(2005). A formação de redes de cooperação e clusters em países emergentes: uma alternativa para PMES no Brasil. In: AMATO NETO, J. (Org.) Redes entre organizações: domínio do conhecimento e da eficácia operacional. São Paulo: Atlas, 2005.

LIPIETZ, A.; LEBORGNE, D. (1988). O Pós-Fordismo e seu espaço. Revista Espaço e Debates. São Paulo, ano VIII, Neru (25).

LIPNACK, J.; STAMPS, J. (1994). Rede de Informações: São Paulo, Makron Books.

LUNDVALL, B.A (1988). Innovation as an interactive process: from user-producer interaction to the national system of innovation. In: DOSI, G et al. Technical change and economic theory. London: Pinter Publishers.

(1995). National Systems of Innovation: Towards a theory of innovation and interactive learning. Londres: Pinter.

(1992). Introduction. In: LUNDVALL, B. A. (ed.). National Systems of innovation: towards a theory of innovation and interactive learning. London: Pinter.

(2001). Políticas de Inovação na Economia do Aprendizado. Primeira Contribuição ao projeto "Produtividade Local por amostragem setorial e sistemas de inovação no Brasil: novas políticas industriais e tecnológicas. In: Revista Parcerias Estratégicas, Brasília, v. 10, p. 200-218, mar.

LUNDVALL, B. A et al (2001). National systems of production, innovation and competence building. Depart. of Business Studies, Aalborg university. DRUID Conference, Aalborg, june 12-15. 
MACHADO, S. (2003). Dinâmica dos arranjos produtivos locais: um estudo de caso em Santa Gertrudes, a nova capital da cerâmica brasileira. Tese de Doutorado. Escola Politécnica. Departamento de Engenharia de Produção da Universidade de São Paulo.

MAGALHÃES et al. (2007). Incentivando a disseminação e o desenvolvimento de Núcleos SPINS (Software and Systems Process Improvement Network) pelo Brasil.

MALERBA, F. (1992). Learning by firms and incremental technical change. The Economic Journal, v.102, n.413, p. 845-859.

McDEMOTT, R. (2000). Why information technology insired but connot deliver knowledge management. In: Lesse. Knowledge and communities. Woburn: Butterworth-Heinemann.

MCT/SEPIN (2001). Qualidade e Produtividade no Setor de Software Brasileiro. Brasília.

MARCON, M.; MOINET, N. (2000). La stratégie-réseau. Paris: Éditions Zéro Heure. ARCONI, M.A. ; LAKATOS, E. M. (2005). Fundamentos da metodologia científica. $6^{a}$ ed. SP: Atlas, 203p.

MARKUSEN, A. (1995). Áreas de atração de investimentos em um espaço econômico cambiante: uma tipologia de distritos industriais. Revista Nova Economia. Belo Horizonte: UFMG, v.5, n.2, dez.

MARSHALL, A. (1996). Princípios de Economia. São Paulo: Nova Cultural.

MARTELETO, R. M.; SILVA, A. B.O. (2004). Redes e capital social: o enfoque da informação para o desenvolvimento local. Ciência da informação, Brasília, v. 33, n.3. p.41-49.

MATTAR, N. (1993). Pesquisa de Marketing. São Paulo: Atlas.

MCDONALD, BELUSSI, F. (2002). Industrial Districts a State of the Art Review in: Project West and East "Industrial Districts" Re-Location Processes: Identifying Policies in the Perspective of the European Union Enlargement. September, Socio Economic Research.

MENEZES, E. et al. (2005) Política industrial: panorama atual. FUNTELL: Projeto Sistema Brasileiro de Televisão Digital. Modelo de Implantação, OS:40539. CPqD, maio.

MEYER-STAMER, J. (2001). Estratégia de desenvolvimento local e regional: clusters, política de localização e competitividade sistêmica. ILDES, FRIEDRICH EBERT STIFTUNG, Policy Paper, n. 28, setembro de 2001. 
MILES, M. B.; HUBERMAN, A. M. (1994). Qualitative data analysis. Thousand Oaks, CA: Sage.

MINTZBERG, H.; QUINN, J. B. (2001). O processo da estratégia. $3^{\underline{a}}$ ed. Porto Alegre: Bookman.

MIT, SOFTEX, W-CLASS (2003) A indústria de software no Brasil 2002.

Fortalecendo a Economia do Conhecimento, Brasil, 2003.

MOTTA, F. G. (2006). Sistemas locais de produção e cadeias produtivas globais: estudo das diversas formas de inserção da indústria de móveis nos mercado e os impactos nas estruturas produtivas locais. Tese de Doutorado. Escola Politécnica da USP.

NADVI, K. \& SCHMITZ, H. (1999). Clustering and Industrialization: Introduction. World Development, vol.27, n.9, p. 1503-1514.

NAKANO, D.N. Fluxos de conhecimento em redes interorganizacionais: conceitos e fatores de influência, in AMATO NETO, J. (org.) Redes entre organizações: Domínio do conhecimento e da eficácia operacional, Ed. Atlas, SP, 2005.

NELSON, R.;WINTER, S. (1982). An Evolutionary Theory of Economic Change. Cambridge: The Belknap Press of Harvard University Press.

NELSON, R. R. (1991) .Why do firms differ, and how does it matter? Strategic Management Journal, v.12, p.61-74,

NICOLAU, J. A.; CAMPOS, Renato Ramos; CÁRIO, S. A. F. (2001) . Arranjos produtivos locais: o caso da indústria de software. In: Luís Fernando Tironi. (Org.). Industrialização descentralizada: sistemas industriais locais. Brasília: IPEA, v., p. 499-533.

NICOLAU, J. A.; CAMPOS, Renato Ramos ; CÁRIO, S. A. F. (2000). A indústria de software de Joinville: um estudo de caso de arranjo inovativo local. Relatório Final de Pesquisa. NEITEC. UFSC. Florianópolis.

NOGUEIRA, M.O (2006). Qualidade no setor de software brasileiro: uma avaliação das práticas das organizações. Tese de Doutorado. Universidade Federal do Rio de Janeiro, COOPE.

NOHRIA, N. (1992). Is a network perspective a useful way of studying organizations? In: NOHRIA, N. \& ECCLES, R. G. (ed.) Networks and organizations: structure, form, and action. Boston, Massachussets: Harvard Business School Press, p. 1-22.

NONAKA, I. et. Al. (2001). Knowledge emergence: social, technical, and evolutionary dimensions of knowledge creation. Oxford: University Press.

NONAKA, I.; TAKEUCHI, H. (1997). Criação de conhecimento na empresa. Rio de Janeiro: Campus,. 
NONAKA, I.; TOYAMA, R. (2002).A firm as a dialectical being: towards a dynamic theory of a firm. Industrial and Corporate Charge, v.11, p. 995-1009,

NONAKA, I.; TOYAMA, R.; KONNO, N. (2002). SECI, ba and leadership: a unified model of dynamic knowledge creation. In: Managing knowledge an essential reader. London, Sage Publications,.

NONAKA , I.; TAKEUCHI, H. (1995). The knowledge-creating Company. New York: Oxford University Press.

NONAKA, I.; TEECE, J. (2001). Managing industrial knowledge: creation, transfer and utilization, Sage Publication, London -Thousand Oaks -New Delhi

NORTH, D. (1990). Institutions, institutional change and economic performance. Cambridge: Cambridge University Press.

OCDE (2004) Digital Delivery of Business Services, Working Party on the Information Economy, Directorate for Science Technology and Industry.

OLIVEIRA, S. L. (1999). Trabalho de Metodologia Científica: projetos de pesquisas, TGI, TCC, Monografias, Dissertações e Teses. São Paulo: Editora Pioneira.

OLIVER, C. (1990). Determinants of the interorganizational relationships: integration and future directions. The Academy of Management Review, v.15, n.2, p.241-265, 1990.

PAULK, M.; CURTIS, C. B. CHRISSIS, M.;WEBER, C. V (1993). Capability maturity model. IEE Software. P.18-27. July.

PAULK, M.; WEBER, C. V.;CURTIS, B. et al. (1995). The Capability Maturity Model: guidelines for improving the software process. Addison Wesley Longman, Inc. Massachussets.

PAVITT, K. (1984). Sectoral patterns of technical change: towards a taxonomy and a theory. Research Policy, North-Holland, v.13, n.4.

PRAHALAD, C. K.; HAMEL, G. (1990). The core competence of the corporation, Harvard Business Review, v.68, p.79-91.

PERROW, C. (1992). Small-Firm Networks. In: Nohria, N. ; Eccles, R. Networks and organizatios: structure, form and action. Boston: Harvard Business School Press, 1992.

PESSÔA, M. S.; SPINOLA, M. M. (2001). CMM aplicado à melhoria dos processos de software. In: WEBER, K. C.; ROCHA, A R. C.; NASCIMENTO, C. J. Qualidade e produtividade em software. São Paulo: Makron Books.

PÊSSOA, M. S. (2003). Introdução ao CMMI: modelo integrado de maturidade de capacidade de processo. Lavras: UFLA/FAEPE. 
(2005). Introdução ao CMMI, Modelo Integrado de Maturidade de Capacidade de Processo. Lavras, MG: Gráfica Universitária. UFLA, 87p. PFLEEGER, S. L. (2001). Software Engineering - Theory and Practice. Shari Lawrence Pfleeger. ( $2^{\text {nd }}$ ed.) Prentice Hall.

PIORE, M. J.; SABEL, C. F. (1984). The second industrial divide: possibilities for prosperity. New York: Basic Books.

PINHEIRO, M. (1996). Gestão e desempenho das empresas de pequeno porte: uma abordagem conceitual e empírica. São Paulo. Dissertação (Mestrado). Faculdade de Economia e Administração, Universidade de São Paulo.

POLANYI, M. (1967). The Tacit Dimension.. New York: Anchor Day Books.

PONDÉ, J. L. (1993). Competitividade da indústria de software. Campinas. Nota técnica para o "Estudo da Competitividade da Indústria Brasileira".

PORTO, D.; CANO, N.;SILVA, A. L. G. (2000). Arranjo produtivo de telecomunicações de Campinas/SP. Relatório Final, Contrato BNDES/FINEP/FUJB. Arranjos e Sistemas Produtivos Locais e as Novas Políticas de Desenvolvimento Industrial e tecnológico, NT,8, IE- UFRJ.

PORTER, M. E. (1998). Clusters and the new economics of competition. Harvard Business Review. Boston, EUA, v. 76, n. 6, p. 77-90, november - December.

(1993). Vantagem competitiva das nações. Rio de Janeiro: Campus.

(1999) Competição: estratégias competitivas essenciais. Rio de Janeiro:

Campus.

PUTNAM, R. D. (2002). Comunidade e Democracia - a experiência da Itália moderna. Rio de Janeiro: Getúlio Vargas, $3^{\underline{a}}$ edição.

RABELOTTI, R. (1995). Is there an Industrial District model? Footwear Districts in Italy and Mexico Compared. World Development. Vol.23, n.1, p.29-41.

RAIS - Relação Anual de Informações Sociais.(2003). Ministério do Trabalho e Emprego. CD-rom.

RAPINI, M.;CASSIOLATO, J.E.;CAMPOS, R.;BRITTO, J. (2004). Mensuração e diferenciação de fluxos de conhecimento e informação em APLs brasileiros. Nota Técnica 07.Texto do Projeto Aprendizado, Capacitação e Cooperação em Arranjos Produtivos e Inovativos Locais de MPE's: implicações para políticas. Disponível em: http://www.ie.ufri.br/redesist Acesso em: 07/02/2006.

RAUEN, A.T. (2006). O sistema local de inovação da indústria de software de Joinville: os limites da diversificação de um meio inovador. Dissertação de Mestrado. UNICAMP. Instituto de Geociências. 
RIBAULT, M.; MARTINET, B.; LEBIDOIS, D. (1995). A gestão das tecnologias. Coleção gestão \& inovação. Publicações Dom Quixote. Lisboa.

RIBEIRO, A. R. (1998). Empresas brasileiras desenvolvedoras de software: uma avaliação das condições de qualidade e competitividade. Campinas, SP.

ROCHA, A.R.C; MALDONADO, J.C.; WEBER. K. C. (2001). Qualidade de software: teoria e prática. Prentice Hall, São Paulo.

ROSELINO, J. E. (2003). Relatório Setorial Preliminar do setor de sotware. FINEP Rede DPP.Disponível em:

http://www.finep.gov.br/portalDPP/relatorio setorial/impressão relatório.asp?lst seto r Acesso em:15/09/2004

(2006). A indústria de software: o "modelo brasileiro"em perspectiva comparada. Tese de Doutorado. Instituto de Economia. Universidade Estadual de Campinas.

ROSELINO, J. E. (2006b). Panorama da indústria brasileira de software: considerações sobre a política industrial. Disponível em:

http://www.ipea.gov.br/sites/000/2/livros/estrutnturadinamica/capitulo\%208 roselino. pdf. Data de acesso: 10/05/07.

(2007). Relatório Setorial Final. Setor Software. FINEP. Rede DPP.

Disponível em:

http://www.finep.gov.br/portalDPP/relatorio_setorial_find_relatorio_setorial_final_impr essao-asp?ist_setor $=17$

ROSELINO, J. E.; GOMES, R. (2000). Software e as cadeias produtivas internacionalizadas in Limites e possibilidades do Brasil nas configurações produtivas globalizadas. Araraquara, Campinas, 2000.

RUIZ, J. A. (2002) Metodologia científica: guia para eficiência nos estudos. São Paulo: Atlas.

SALATTI, R. (2005). Flexibilização do trabalho em empresas de desenvolvimento de sistemas. Dissertação de mestrado. Departamento de Política Científica e tecnologia. UNICAMP. Campinas.

SALOMON, D.V. (1999). Como Fazer uma Monografia. 9.ed.São Paulo: Martins Fonseca.

SALVIANO, C. F. (2006). Uma proposta orientada a perfis de capacidade de processo para evolução da melhoria de processo de software. Tese de Doutorado. Faculdade de Engenharia Elétrica e de Computação da Universidade Estadual de Campinas (FEE-UNICAMP).

SANTOS, L. C.; VARVAKIS, G. (1999). Redes de pequenas e médias empresas: organizações virtuais vs. Clusters. (CD ROOM) In: Anais ENANPAD, 23. 
SANTOS, G. A.G.; DINIZ, E. J.; BARBOSA, E. K. (2004). Aglomerações, arranjos produtivos locais e vantagens competitivas Vocacionais. Revista do BNDES. Rio de Janeiro, v. 11, n. 22, p. 151-179, dez.

SCHMITZ, H. (1995). Small shoesmakers and fordist giants: tales of a supercluster. World Development, vol.23, n.1, p. 9-28.

(1997). Eficiência coletiva: caminho de crescimento para a indústria de pequeno porte. In: Ensaios FEE. Porto Alegre 18 (2): 164-200.

(1999). Global competition and local cooperation: success and failure in the Sinos Valley, Brazil. World Development, v, 27, n.9, p. 1627-1650.

SCHUMPETER, J.(1984). Capitalismo, socialismo e democracia. Rio de Janeiro: Zahar.

SCOTT, A.(1998). The geographic foundations of industrial performance. In: A.. Chandler Jr., P. Hagstrom e O. Solvell (eds), The Dynamic Firm - The role of Technology, Organization and Regions. Oxford: Oxford University.

SEBRAE NACIONAL (1998). Informações Empresariais - classificação de empresas. http://www.sebrae.org.br/novo_site/portugues/inf_empresariais/inf_empresariais.htm

SEBRAE (2006) Diagnóstico da indústria de software de Belo Horizonte. Fundação João Pinheiro. Governo de Minas Gerais.

SILVA, G. S. (2006). Geração e difusão do conhecimento em SLP's. Tese de Doutorado. Escola Politécnica da Universidade de São Paulo. São Paulo.

SILVA, L. S. (1989). Qual foi a contribuição da Oktoberfest no desenvolvimento: econômico, sócio cultural e turístico de Blumenau. Blumenau: Universidade Regional de Blumenau.

SIMIONI, M. (2001). Processo de aprendizagem produtor-usuário nas empresas de software no município de Joinville - Santa Catarina. Dissertação de Mestrado. Departamento de Economia. UFSC. Florianópolis.

SIMÕES, J. (2005). Regulamentação da lei de informática em fase final: governo diz que vai simplificar o acesso e incentivar mais P\&D do exterior, Inovação UNICAMP, http://www.inovacao.unicamp.br/report/news-leideinformatica.shtml.

SOFTEX (2004). Mercado de Software - Notícias. Disponível em: www.softex.org.br (2005). Estrutura do Modelo MPS.BR. Disponível em: www.softex.org.br

SOMMERVILLE, I. (1996). Software Process Models. ACM Computing Surveys. Vol. 28. N.1, p.169 - 180. The Association for Computing Machinery (ACM) New York.

SOMMERVILLE, I. (2003). Engenharia de Software. Addison Wesley, 6 edição. 
SOUSA, S. V. A. (2004). Contrapontos e similaridades entre o desenvolvimento da indústria de software no Brasil e no mundo. Revista de Administração da UNIME União Metropolitana de Educação e Cultura, vol.2, n.1, jan/jul.

SOUZA, M. C.A.F. et al. (1998). Inserção Competitiva das empresas de pequeno porte. Brasília, MCT.

SOUSA, M.C.A.F.; GARCIA, R. (1998). O arranjo produtivo de indústrias de alta tecnologia da região de Campinas. Estado de São Paulo-Brasil. Nota Técnica no.27/99. Instituto de Economia da universidade Federal do Rio de Janeiro, Mangaratiba, dez.

SOUSA, N. A. (2005). Arranjos produtivos locais: o caso de chapas e laminados de Ponta Grossa. Dissertação de Mestrado. Universidade Federal do Paraná.

STEFANUTO, G. N. (2002). A indústria de software no Brasil - 2002: fortalecendo a economia do conhecimento. In: Capítulo Brasil do Projeto: Slicing the KnowledgeBased Economy (KBE) in India, China and Brasil: a tale of three software industries. Institute of Technology - MIT; Brasil Coordenação geral Sociedade Softex.

Campinas.

STEFANUTO, G. N. (2004). O programa Softex e a indústria de software no Brasil. Tese de Doutorado. Instituto de Geociências. UNICAMP. Campinas.

STEFANUTO, G. N.;CARVALHO, R. Q. (2005) Perfil das empresas exportadoras de software. DPCT/IG Unicamp e Observatório Digital Softex.

STORPER, M. (1994). Territorialização numa economia global: possibilidades de desenvolvimento tecnológico, comercial e regional em economias subdesenvolvidas. In: LAVINAS, L. (Org.) Integração, Região e Regionalismo. Rio de Janeiro: Bertrand Brasil S\&A..

SOFTEX, Sociedade para a Promoção da Excelência do Software Brasileiro (2005). MPS.BR - Melhoria de Processo de Software Brasileiro - Guia Geral (versão 1.0). Disponível em http://www.softex.br. Acesso em 11 de setembro de 2007.

(1996). Innovation as collective action: convention, products and technologies. Industrial Corporate Changes, v.5 n.3 pg 761-789

(1997). The regional world. Territorial Development in a Global Economy. Londres: The Guilford Press.

STUART, T. E. (1998). Network positions and propensities to collaborate: na investigation of strategic alliance formation in a high-technology industry. Administrative Science Quaterly, v. 43, n.3, p.668-698, 1998.

SUZIGAN, W et al. (2003). Sistemas locais de produção: mapeamento, tipologia e sugestões de políticas. Anais do XXXI Encontro Nacional de Economia. Porto Seguro, Ba, 9-12 de dezembro de 2003. 
SUZIGAN, W.; FURTADO, J.; GARCIA, R.; SAMPAIO, S. E.K. (2004). Inovação e conhecimento: indicadores regionalizados e aplicação a São Paulo. Anais do XXXII Encontro Nacional de Economia - ANPEC. João Pessoa, PB, 6-10 de dedezembro de 2004.

SUZIGAN, W ; GARCIA, R.; FURTADO, J.;(2003). Governança de sistemas produtivos locais de micro, pequenas e médias empresas. In: LASTRES, H.M.M.; CASSIOLATO, J. E.;MACIEL, M. L. (Org.). Pequena Empresa: cooperação e desenvolvimento local. Rio de Janeiro: Relume-Dumará:UFRJ, Instituto de Economia, 2003. Cap. 4, p. 67-83.

SUZIGAN et al. (2005). Localização, inovação e aglomeração: o papel das instituições de apoio às empresas no estado de SP. São Paulo em Perspectiva, v.19. n.2, p.86-100.

(2001). Sistemas produtivos locais no estado de SP: o caso da indústria de calçados de Franca. In: Tironi, L. F. (coord.) Industrialização descentralizada: sistemas industriais locais. Brasília, IPEA.

TAKAHASHI, T. (2000). Sociedade da informação no Brasil: livro verde. Brasília: Ministério da Ciência e Tecnologia.

TAKEDA, J. (2001). Modelagem de redes de cooperação: abordagem metodológica de sistemas complexos e aplicação no modelo de gerenciamento de projetos cooperativos no Instituto Tecnológico do Paraná. Dissertação de Mestrado. Centro Federal de Educação Tecnológica do Paraná. Curitiba.

TEECE, J. (1998). Capturing Value from Knowledge Assets. California Management Review, vol.40, n.3, spring, p. 55-79.

TEECE, D.; PISANO, G. (1994). The dynamic capabilities of firms: an introduction. Industrial and Corporate Change, v.1,n.3.

TERRA, J. C. C. (2000). Gestão do conhecimento: o grande desafio empresarial. São Paulo: Negócio, 2000.

2003. Disponível em:

Comunidade de Prática: conceitos, resultados e métodos de gestão. $<$ http://www.terraforum.com.br/lib/pages/viewdoc.php?from=map\&l intDocCod=98 $>$. Acessado em 09/02/2008.

THIOLLENT, M. (1986). Metodologia da Pesquisa-ação. São Paulo: Cortez, 3aㅡ ed.

WASSERMAN, S.; FAUST, K. (1994). Social Networks Analisys: Methods and Applications. Cidade: Cambridge University Press, 1994.

WEBER, K. C.; ARAÚJO, E. (2007) Avaliação do Modelo MPS em Empresas em 2005 e 2006. Disponível em: http://www.softex.br. Data de acesso: 26/10/2007. 
WEBER, K. C. et al. (2006). Melhoria de Processo do Software Brasileiro (MPS.BR): um Programa Mobilizador. Disponível em: http://www.softex.br. Data de acesso: 26/10/2007.

WENGER, E. (1998) Communities of practice: learning, meaning, and identity. USA, Cambridge University Press.

(1999). Communities of practice. Stewarding Knowledge. November 6.

WILLIANSON, O.(1985). Markets and hierarchies: analysis and antitrust implications. New York: Free Press.

VARGAS, M. A. (2002) Proximidade territorial, aprendizado e inovação: um estudo sobre a dimensão local dos processos de capacitação inovativa em arranjos e sistemas produtivos no Brasil. Tese de Doutorado. Universidade Federal do Rio de Janeiro. Instituto de Economia.

VELOSO, F.; BOTELHO, A .J.J;TSCHANG, T.;AMSDEN, A .(2003). Slicing the Knowledge-based Economy in Brazil, China and India: A Tale of 3 Software Industries. Report. Massachussetts Institute of Technology (MIT), September.

VIESTI, G. (2000). Come nascono I distretti industrialli. Laterza, Bari.

VON HAYEK, F.;(1945). The Use of Knowledge in Society. The American Economic Review, vo. 35, issue 4, September, p. 519-530.

VOSS, C. et al. (2002). Case research in Operations Management. International Journal of Operations \& Production Management, vol. 22, n.2, p.195-219

YIN, R. (1994). Case study research: design and methods. $2^{a}$ ed. London: Sage Publications, vol5.

Bookman.

(2001). Estudo de caso: planejamento e métodos. 2. Ed. Porto Alegre:

ZUKOVSKI, J. C. (1994). Indústria Brasileira de Software: Evolução Histórica e Análise dos Efeitos da Lei 7646/87, com Enfoque para o Mercado de Software para Microcomputadores, Dissertação de Mestrado. Instituto de Economia. Unicamp. Campinas. 


\section{APÊNDICE A - ROTEIRO DE ENTREVISTA ÀS INSTITUIÇÕES DE APOIO ÀS EMPRESAS DO SETOR DE SOFTWARE}

\section{Escola Politécnica da USP \\ Departamento de Engenharia de Produção}

1-Caracterização da Instituição de Apoio

\begin{tabular}{|l|l|}
\hline Nome & \\
\hline Endereço & \\
\hline Fone & \\
\hline Fax & \\
\hline E-mail & \\
\hline Home page & \\
\hline N. de Funcionários & \\
\hline N. de associados/clientes & \\
\hline Pessoa Entrevistada & \\
\hline Cargo & \\
\hline Data da Entrevista & \\
\hline
\end{tabular}

2- Breve histórico da instituição (Fundação, objetivo inicial, enfoque atual).

3- Como a instituição se mantém (natureza e origem dos recursos)? 
4- Descreva as principais ações voltadas às PME's do setor de software. Dentre elas, os principais esforços para a disseminação de conhecimentos e capacitação das empresas em melhoria de processos de software e qualidade:

5-Quais benefícios e/ou vantagens as PME's podem ter em participar das atividades da instituição?

6 -Como a instituição identifica as demandas e preocupações das PME's relacionadas à melhoria de processos de software e qualidade e quais são as principais por ordem de importância?

7- Como é o perfil das empresas que se interessam nas atividades voltadas à melhoria de processos e capacitação em qualidade da instituição? Em sua maioria, pertencem ao arranjo produtivo local?

8- Considerando as dificuldades das PME's com relação à escassez de recursos, como a instituição apóia, promove ou oportuniza condições para facilitar o acessos destas empresas às ações desenvolvidas pela instituição?

9- Como as empresas decidem pela metodologia mais adequada de controle de seus processos e qualidade de software?

10- Existem regras, requisitos para a participação e permanência em grupos cooperados de PME's de software para implementação e avaliação de Modelos de Negócio para Melhoria de Processo de Software ? Como essas empresas são 
selecionadas e avaliadas? Como os grupos são formados e/ou constituídos ? (Somente IOGES)

11- Existem sanções no caso de desistências das empresas ao longo dos trabalhos do grupo? Como são aplicadas? (Somente para IOGES)

12- Como a Instituição avalia e atua sobre o controle dos resultados obtidos pelas empresas?

13- Com relação às atividades de melhoria de processos de software e qualidade, indique por ordem de importância, os fatores decisivos na utilização destes serviços, por parte das empresas:

( ) preço acessível do serviço

( ) qualidade / garantia dos serviços

( ) única instituição de apoio local que presta determinados serviços

( ) propaganda / marketing

( ) confiabilidade na instituição / tradicional

( ) por ser uma instituição pública

( ) Outro. Qual?

14-Como as metodologias de gestão de software são assimiladas pelas empresas? Como é o processo de socialização do conhecimento? 
15- Qual a fonte de prospecção de tendências, inovações e necessidades das empresas para o desenvolvimento das ações da instituição de modo geral ?

\begin{tabular}{|l|l|l|}
\hline FONTE & SIM & NÃO \\
\hline a) Fornecedores & & \\
\hline b) Feiras e Exposições & & \\
\hline c) Produtores locais & & \\
\hline c) Produtores de outras localidades & & \\
\hline d) Clientes da região & & \\
\hline e) Publicações setoriais e especializadas & & \\
\hline f) Outras instituições da região & & \\
\hline g) Consultores especializados da região & & \\
\hline h) Consultores especializados de outras localidades & & \\
\hline i) Bibliotecas e serviços de informação & & \\
\hline j) Congressos e seminários nacionais & & \\
\hline k) Congressos e seminários internacionais & & \\
\hline l) SEl & & \\
\hline Outra & & \\
\hline & & \\
\hline
\end{tabular}

16-Como a instituição avalia a adequação e o atendimento às necessidades das empresas com relação às ações desenvolvidas pela instituição? Com que frequência? 
17-A instituição tem por hábito oportunizar a discussão de estratégias, problemas, novas idéias, boas práticas com e entre empresas, ou com outras instituições locais?

a) Com empresas:

( ) Nunca Por quê:

( ) Ocasionalmente

( ) Frequentemente

Como?

b) Entre empresas:

( ) Nunca Por quê:

( ) Ocasionalmente

( ) Frequentemente

Como:

b) Com outras instituições:

( ) Nunca Por quê:

( ) Ocasionalmente

( ) Frequentemente

Como:

18- $\mathrm{Na}$ sua opinião, quais são as fontes de informação mais utilizadas pelas empresas na aquisição de conhecimentos relacionados à boas práticas de qualidade e melhoria de processos de software?

19- Como a instituição divulga suas ações junto às empresas do pólo? 
20- Na sua opinião, quais as principais vantagens competitivas das empresas locais e quais os fatores mais críticos (oportunidades subaproveitadas)?

21- Quais são as maiores dificuldades para a existência de cooperação entre as PME's locais e as instituições de apoio e suporte?

22- Na sua opinião, como as PME's podem construir formas de colaboração/cooperação a fim de se tornarem mais inovadoras e sustentarem conhecimento?

23- Como boas práticas, podem ser melhor disseminadas entre as empresas?

24- Quais são as dificuldades desta instituição para um apoio mais efetivo ao setor?

25- Quais as perspectivas futuras desta instituição para o desenvolvimento do setor?

26- Quais são os projetos atuais e cooperações já desenvolvidas com as PME's locais? (Pode-se mencionar também projetos com empresas não locais). 


\section{APÊNDICE B - LEVANTAMENTO SOBRE APRENDIZAGEM E COOPERAÇÃO NAS EMPRESAS DE SOFTWARE}

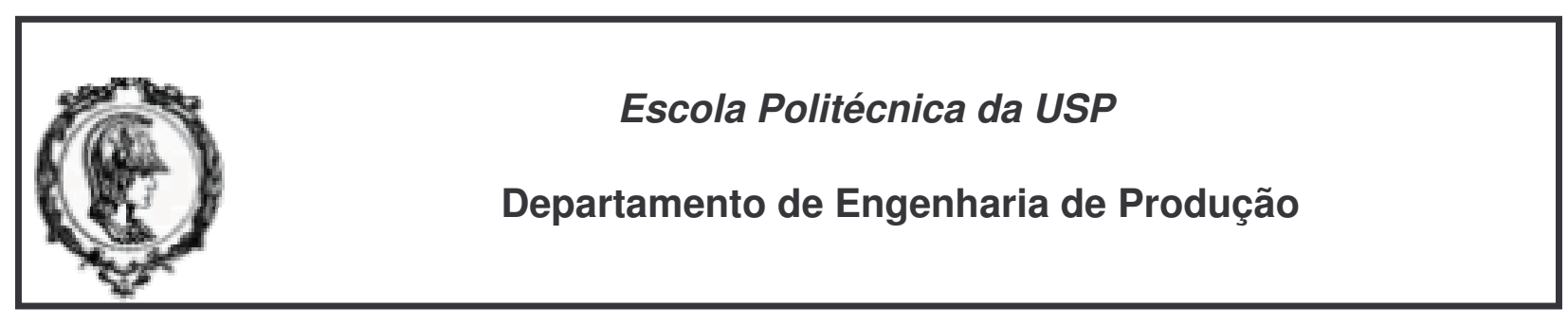

Prezado Senhor (a)

Esta pesquisa pertence ao grupo Redes de Cooperação e Gestão do Conhecimento do Departamento de Engenharia de Produção da Universidade de São Paulo que tem como objetivo investigar as alternativas de elevar o desempenho das empresas e seu poder de competitividade através dos arranjos interorganizacionais e das redes de cooperação produtiva, bem como identificar as oportunidades e as barreiras relativas ao aprendizado das empresas e a difusão do conhecimento.

Dentro desta proposta, temos muito interesse em conhecer melhor a indústria de software, suas necessidades e potencialidades, sobretudo as pequenas e médias empresas (PME's) que possuem um importante papel neste contexto. $O$ foco principal desta pesquisa está em conhecer como essas empresas podem aprender e gerar conhecimento através de processos de aprendizagem interativa em qualidade e melhoria de processos de software, uma necessidade bastante presente para as empresas.

Para isso, gostaríamos muito de poder contar com a sua colaboração em responder esta pesquisa. Sabemos que a quantidade de trabalho nas empresas é grande e o tempo curto. Porém, sua participação para nós pesquisadores, é muito valiosa, sem a mesma, perderemos informações de grande relevância.

Desde já, coloco-me à disposição para apresentar os resultados da pesquisa, o que poderá ser feito a partir de março de 2008 
Agradeço muito a atenção dispensada!

Cordiais Saudações

Ana Paula dos Reis Almeida

Doutoranda da Engenharia de Produção da USP

e-mail: anapaulareis@hotmail.com / ana.reis@poli.usp.br 
Razão Social:

Nome Fantasia:

Endereço:

Bairro:

Cidade: UF: $\quad$ CEP:

Telefones:

Home Page: E-mail:

Data de Fundação (mm/aaaa):

Nome do Entrevistado:

Cargo/função:

Formação:

Tempo de Empresa:

Número de Sócios:

Origem do(s) sócio(s):

( ) outras empresas ( ) centros de pesquisa ou universidade ( ) outras empresas de software

Escolaridade do (s) sócio (s):

Tamanho da Empresa:

( ) Micro (de 1 a 20 funcionários)

( ) Pequena (de 21 a 100 funcionários)

( ) Média (de 101 a 500 funcionários)

Número de funcionários hoje:

Origem do capital controlador da empresa:
(...) Nacional
( ) Estrangeiro
( ) Nacional e Estrangeiro 
Qual o faturamento anual bruto da empresa?

( ) Menos de $\mathrm{R} \$ 100.000,00$

( ) Entre $R \$ 100.001,00$ e $R \$ 250.000,00$

( ) Entre $R \$ 250.001,00$ e $R \$ 500.000,00$

( ) Entre $R \$ 500.001,00$ e $R \$ 1.000 .000,00$

( ) Entre $R \$ 1.000 .001,00$ e $R \$ 6.000 .000,00$

( ) Entre $R \$ 6.000 .001,00$ e $R \$ 12.000 .000,00$

( ) Entre $R \$ 12.000 .001,00$ e $R \$ 60.000 .000,00$

( ) Mais de $R \$ 60.000 .000,00$

2- Caracterização Produtiva, Comercialização e Concorrência

Destino da Produção: （ ）Local ( ) Estadual ( ) Nacional (..) Exportação

Se a empresa exporta, indique:

\begin{tabular}{|l|l|c|}
\hline Principais Produtos & Países de Destino & $\begin{array}{c}\text { Canais de } \\
\text { Comercialização }\end{array}$ \\
\hline A. & & \\
\hline B. & & \\
\hline C. & & \\
\hline
\end{tabular}

Caso a empresa exporte, qual a forma de entrada no mercado externo?

Qual atividade de software a empresa realiza? (Permitido múltipla escolha)

( ) Produz software pacote

( ) Produz software pacote com adaptações a clientes (customizado)

( ) Produz software embarcado

( ) Produz software sob encomenda

( ) Realiza consultoria para implantação de sistemas

( ) Presta serviços de manutenção e assistência técnica em software

( ) Comércio de equipamentos

( ) Comércio de software produzido por terceiros

( ) Outros (especificar): 
Qual(is) o(s) domínio(s) de software (s) desenvolvido(s) pela empresa?
( ) Administração privada
( ) Administração pública
( ) Agropecuária/agribusiness
( ) Bancário
( ) Comércio
( ) Educação
( ) Engenharia, arquitetura, const. civil
( ) Entretenimento
( ) Financeiro
( ) Indústria
( ) Meio Ambiente
( ) Qualidade e Produtividade
( ) Saúde
( ) Serviços
( ) Telecomunicações
( ) Transportes
( ) Turismo
( ) Outros Especifique:

Qual(is) o(s) tipo(s) de aplicação de software desenvolvidos pela empresa?

( ) Administração de recursos humanos

( ) Administração escolar

( ) Automação bancária

( ) Automação de escritórios

( ) Automação predial

( ) Computação gráfica

( ) Contabilidade

( ) Educação à distância software

( ) Gestão de conteúdo

- CRM

( ) Geoprocessamento

( ) Gerenciador de redes

( ) Gestão de documentos

( ) Gestão integrada - ERP

( ) Página WEB texto

( ) Processador de imagens

( ) Serviços de mensagens

( ) Utilitários Especifique:

( ) Outros Especifique:
( ) Administração de serviços

( ) Administração jurídica

( ) Automação comercial

( ) Automação industrial

( ) Comércio eletrônico

( ) Comunicação de dados

( ) E-business

( ) Ferramenta/ambiente de desenv. de

( ) Gestão do relacionamento com o cliente

( ) Gerenciador de banco de dados

( ) Gestão da qualidade

( ) Gestão do conhecimento

( ) Jogos

( ) Planilha eletrônica e Processador de

( ) Segurança e Proteção de Dados

( ) Simulação e modelagem 
A empresa é subcontratada para realizar alguma atividade? Quais e em qual (is) cidades se localizam os contratantes?

Se respondeu sim na questão anterior, qual a caracterização da subcontratação?

\begin{tabular}{|l|l|l|}
\hline Tipo de contrato & ( ) Informal & ( ) Escrito \\
\hline Prazo do contrato & $\begin{array}{l}\text { ( ) Por tempo } \\
\text { determinado }\end{array}$ & ( ) Por operação \\
\hline $\begin{array}{l}\text { Exclusividade } \\
\text { contrato }\end{array}$ & $\begin{array}{l}\text { ( ) Atende apenas a } \\
\text { firma }\end{array}$ & ( ) Atende outras firmas \\
\hline
\end{tabular}

Quem são os principais compradores de bens e serviços desenvolvidos pela empresa?

Quem são os principais concorrentes da empresa?

\begin{tabular}{|l|l|l|l|}
\hline Nomes & Local Nocalização \\
& & & \\
& & & \\
\hline & & & \\
\hline & & & \\
\hline
\end{tabular}

Quem são os principais clientes da empresa?

\begin{tabular}{|l|l|l|l|}
\hline Nomes & \multicolumn{3}{|c|}{$\begin{array}{c}\text { Localização } \\
\text { Nacional Exterior }\end{array}$} \\
\hline & & & \\
\hline & & & \\
\hline & & & \\
\hline
\end{tabular}

\section{3- Perfil e Desenvolvimento dos Recursos Humanos}

Escolaridade formal do pessoal ocupado com vínculo permanente: 


\begin{tabular}{|l|l|l|l|l|}
\hline & $\begin{array}{c}\text { Administrativo } \\
\text { (Número) }\end{array}$ & $\begin{array}{c}\text { Produção } \\
\text { (Número) }\end{array}$ & $\begin{array}{c}\text { Pesquisa } \\
\text { (Número) }\end{array}$ & $\begin{array}{c}\text { Controle/Gestão } \\
\text { Qualidade } \\
\text { (Número) }\end{array}$ \\
\hline $\begin{array}{l}\text { Até o Ensino } \\
\text { Fundamental }\end{array}$ & & & & \\
\hline $\begin{array}{l}\text { Ensino Médio } \\
\text { Completo }\end{array}$ & & & & \\
\hline $\begin{array}{l}\text { Técnico Completo } \\
\text { (nível Ensino Médio, } \\
\text { mas do tipo técnico ou } \\
\text { profissionalizante) }\end{array}$ & & & & \\
\hline Superior Completo & & & & \\
\hline Pós-graduação & & & & \\
\hline
\end{tabular}

Quais os requisitos de qualificação importantes para a contratação de pessoas para a gestão da qualidade e melhoria de processos de software (formação; cursos; experiência, etc)?

Como a empresa busca melhorar a qualificação/capacitação das pessoas em qualidade e processos de software?

Como a empresa avalia a contribuição oferecida pela estrutura educacional local (universidades, escolas técnicas, instituições de apoio, etc) para o desenvolvimento dos recursos humanos em aspectos relacionados à qualidade e melhoria de processos de software? Explique:

Indique e avalie a instituição ou agente realizador da qualificação e/ou capacitação da mão de obra da empresa:

A empresa possui algum convênio com escolas ou institutos para educação e qualificação técnica dos funcionários? Se sim, no que consiste?

\section{4- Aprendizagem, Cooperação, Inovação}


Qual a motivação e/ou interesse pelo qual a empresa tem buscado melhorar seus processos de software?

Qual metodologia de melhoria de processos a empresa utiliza? Qual o critério utilizado para a escolha da mesma?

A empresa participa e/ou participou de algum modelo cooperado de negócio para obter serviços melhoria de processos de software? Qual programa? Quais as principais razões pelas quais a empresa decidiu participar de um modelo cooperado?

Foram necessários conhecimentos ou qualificações anteriores para poder participar do projeto? Quais?

As empresas compartilham informações entre si? De que forma? Qual o conteúdo das informações compartilhadas entre as empresas?

Qual a periodicidade dos encontros compartilhados?

Comente sobre as vantagens em participar de um modelo cooperado de negócio? Quais as lições aprendidas e os resultados obtidos no projeto cooperado?

Detalhe as dificuldades enfrentadas e suas conseqüências com relação a implementação/avaliação cooperada?

Qual a importância das parcerias e interações? Desempenham grande influência nos processos de aprendizado e inovação da empresa?

Quanto ao grau de cooperação da sua empresa com as demais do setor, responda:

\begin{tabular}{|l|l|l|l|l|}
\cline { 2 - 5 } \multicolumn{1}{c|}{} & Nulo & Pouco & Médio & Constante \\
\hline 1. Ações conjuntas de Treinamento e & & & & \\
Capacitação & & & & \\
\hline 2. Desenvolvimento Tecnológico & & & & \\
\hline
\end{tabular}




\begin{tabular}{|l|l|l|l|l|}
\hline 3. Vendas em conjunto & & & & \\
\hline 4. Exportação em conjunto & & & & \\
\hline 5. Publicidade & & & & \\
\hline 6. Transporte & & & & \\
\hline $\begin{array}{l}\text { 7. Participação em feiras e missões } \\
\text { empresariais }\end{array}$ & & & & \\
\hline $\begin{array}{l}\text { 8. Troca de informações informais } \\
\text { 9. Grupos de discussões técnicas e de } \\
\text { boas práticas: }\end{array}$ & & & & \\
\hline 10. Outro......Especifique: & & & & \\
\hline
\end{tabular}

Preencha a tabela abaixo, onde são avaliadas as importâncias das ações coletivas nos diversos aspectos: (Assinale com $X$ o grau de importância da parceria, conforme a legenda)

\section{Legenda:}

0- Não contribui

1- Traz algum benefício para a empresa

2- Proporciona benefícios importantes para a competitividade da empresa

3- Muito importante para desenvolver a competitividade da empresa e beneficia 0 desenvolvimento do pólo

\begin{tabular}{|l|l|l|l|l|l|l|}
\hline Ações Coletivas & \multicolumn{2}{|c|}{ Grau de importância } & \multicolumn{2}{c|}{ Participação } \\
\hline & 0 & 1 & 2 & 3 & SIM & NÃo \\
\hline $\begin{array}{l}\text { 1. Treinamento e Capacitação de } \\
\text { Recursos Humanos }\end{array}$ & & & & & & \\
\hline $\begin{array}{l}\text { 2. Desenvolvimento Tecnológico } \\
\text { 3. Vendas em conjunto }\end{array}$ & & & & & & \\
\hline 4. Exportação em conjunto & & & & & & \\
\hline $\begin{array}{l}\text { 5. Publicidade } \\
\text { 6. Transporte }\end{array}$ & & & & & & \\
\hline $\begin{array}{l}\text { 7. Participação em feiras e missões } \\
\text { empresariais }\end{array}$ & & & & & & \\
\hline 8. Grupos de discussões técnicas e de & & & & & & \\
\hline
\end{tabular}




\begin{tabular}{|l|l|l|l|l|l|l|}
\hline boas práticas & & & & & & \\
\hline 9. Obtenção de Financiamento & & & & & & \\
\hline 10. Outra Especifique: & & & & & & \\
\hline
\end{tabular}

Qual a principal dificuldade para melhorar a cooperação entre a sua empresa e as demais do mesmo setor da região?

( ) Desconfiança entre as empresas

( ) Falta de agente articulador que fomente a cooperação

( ) Disputa pelos mesmos mercados

( ) Não reconhecimento da cooperação como forma de aumento da competitividade

( ) Outra Especifique:

Quais principais resultados a empresa tem obtido através de ações conjuntas?

A empresa mantém alguma parceria (formal ou informal) com concorrentes do pólo?

(...) Não

( ) Sim Descreva:

Quais outros tipos de ações conjuntas poderiam trazer melhorias aos processos de software da empresa?

A empresa discute dificuldades técnicas e estratégias de melhoria de processos com outros empresários do pólo de software?

( ) Nunca. Por que?

( ) Ocasionalmente. Explique :

( ) Frequentemente. Explique:

E de outras localidades?

) Nunca. Por que?

) Ocasionalmente. Explique:

) Frequentemente. Explique:

A empresa mantém ou manteve alguma parceria (formal ou informal) para o desenvolvimento de produto ou processo com seus clientes? Caso positivo, no que consiste? Quais os resultados até o momento? 
Qual(is) associações de classe e entidades coletivas a sua empresa faz parte?

Quais os benefícios de ser associado a eles?

Marque com X como sua empresa avalia a importância da contribuição local de associações, entidades coletivas, organizações de apoio e suporte no tocante às seguintes atividades:

\begin{tabular}{|l|l|l|l|l|}
\cline { 2 - 5 } \multicolumn{2}{l|}{} & \multicolumn{3}{c|}{ IMPORTÂNCIA } \\
\hline TIPO DE CONTRIBUIÇÃO & ALTA & MÉDIA & BAIXA & NULA \\
\hline $\begin{array}{l}\text { 1.Auxílio na definição de objetivos } \\
\text { comuns para o APL }\end{array}$ & & & & \\
\hline $\begin{array}{l}\text { 2. Estímulo na percepção de visões de } \\
\text { futuro para ação estratégica }\end{array}$ & & & & \\
\hline $\begin{array}{l}\text { 3. Disponibilização de informações sobre } \\
\text { o setor, assistência técnica, consultoria }\end{array}$ & & & & \\
\hline $\begin{array}{l}\text { 4. Identificação de fontes e formas de } \\
\text { financiamento }\end{array}$ & & & & \\
\hline $\begin{array}{l}\text { 5. Promoção de ações cooperativas } \\
\text { 6. Apresentação de reivindicações } \\
\text { comuns }\end{array}$ & & & & \\
\hline $\begin{array}{l}\text { 7. Criação de fóruns e ambientes para } \\
\text { discussão }\end{array}$ & & & & \\
\hline $\begin{array}{l}\text { 8. Promoção de ações dirigidas à } \\
\text { capacitação tecnológica de empresas }\end{array}$ & & & & \\
\hline $\begin{array}{l}\text { 9. Estímulo ao desenvolvimento do } \\
\text { sistema de ensino e pesquisa local }\end{array}$ & & & & \\
\hline $\begin{array}{l}\text { 10. Organização de eventos técnicos e } \\
\text { comerciais }\end{array}$ & & & & \\
\hline $\begin{array}{l}\text { 11. Abertura de canais de } \\
\text { comercialização (mercado interno) }\end{array}$ & & & \\
\hline \begin{tabular}{l} 
12. Abertura de canais de \\
\hline
\end{tabular} & & & \\
\hline
\end{tabular}




\begin{tabular}{|l|l|l|l|l|}
\hline comercialização (mercado externo) & & & & \\
\hline $\begin{array}{l}\text { 13. Prospecção sobre tendência de } \\
\text { mercados e produtos }\end{array}$ & & & & \\
\hline 14. Outro Descreva: & & & & \\
\hline
\end{tabular}

Quais são as principais fontes que possibilitam à empresa aprendizado convertido em atualização, melhoria ou a introdução de um novo processo /produto ou serviço de software?

\begin{tabular}{|c|c|c|c|}
\hline \multirow[b]{2}{*}{ Fontes Internas } & \multicolumn{3}{|c|}{ Grau de Utilização } \\
\hline & $\begin{array}{l}\text { Muito } \\
\text { freqüente } \\
\text { /frequente }\end{array}$ & Raramente & Não utiliza \\
\hline \multicolumn{4}{|l|}{ P\&D da própria empresa } \\
\hline \multicolumn{4}{|l|}{ Área de Produção } \\
\hline \multicolumn{4}{|l|}{ Área de vendas e marketing } \\
\hline \multicolumn{4}{|l|}{ Serviços de atendimento ao cliente } \\
\hline \multicolumn{4}{|l|}{$\begin{array}{l}\text { Análise crítica dos sucessos e fracassos } \\
\text { de operações e projetos internos }\end{array}$} \\
\hline \multicolumn{4}{|l|}{$\begin{array}{l}\text { Funcionários são incumbidos de reunir } \\
\text { informações fora da empresa }\end{array}$} \\
\hline \multicolumn{4}{|l|}{ Fontes Externas } \\
\hline \multicolumn{4}{|l|}{$\begin{array}{l}\text { Intercâmbio com outras empresas no } \\
\text { pólo (concorrentes, clientes, outros) }\end{array}$} \\
\hline \multicolumn{4}{|l|}{$\begin{array}{l}\text { Intercâmbio com outras empresas fora } \\
\text { do pólo }\end{array}$} \\
\hline \multicolumn{4}{|l|}{ Clientes } \\
\hline \multicolumn{4}{|l|}{ Imitação de produtos de empresas locais } \\
\hline \multicolumn{4}{|l|}{$\begin{array}{l}\text { Imitação de produtos de empresas } \\
\text { brasileiras }\end{array}$} \\
\hline $\begin{array}{l}\text { Imitação de produtos de empresas } \\
\text { estrangeiras }\end{array}$ & & & \\
\hline
\end{tabular}




\begin{tabular}{|l|l|l|l|}
\hline Universidades e centros de pesquisa & & & \\
\hline $\begin{array}{l}\text { Aquisição de licenças, patentes, know- } \\
\text { how }\end{array}$ & & & \\
\hline Catálogos e publicações especializadas & & & \\
\hline $\begin{array}{l}\text { Participação em grupos de discussões } \\
\text { técnicas e gerenciais }\end{array}$ & & & \\
\hline $\begin{array}{l}\text { Visitas à feiras, conferências e } \\
\text { exposições }\end{array}$ & & & \\
\hline $\begin{array}{l}\text { Informações da internet e outros meios } \\
\text { eletrônicos rede }\end{array}$ & & & \\
\hline $\begin{array}{l}\text { Fóruns e participação em rociais informais } \\
\text { baseados na internet ou computador }\end{array}$ & & & \\
\hline Empresas de consultoria & & \\
\hline $\begin{array}{l}\text { Encontros coscificar: } \\
\text { (Restaurantes, clubes, etc) }\end{array}$ & & & \\
\hline Associações empresariais locais & & \\
\hline Outras Especifical & & \\
\hline
\end{tabular}

Na visão da empresa, como as associações e instituições locais de apoio poderiam contribuir mais efetivamente para fomentar o aprendizado coletivo voltado à melhoria de processos de software?

A empresa possui (ou já possuiu) algum contrato ou parceria para desenvolvimento de projetos com universidades, incubadoras ou centros de pesquisa?

( ) Não

( ) Sim Qual:

Mencione os benefícios:

A empresa mantém alguma parceria formal ou informal para melhoria de processos/produtos de software com seus clientes? Qual a contribuição e resultados deste tipo de parceria? 
A empresa pretende realizar investimentos na área de qualidade e/ou melhoria de processos nos próximos 5 anos? Quais serão os objetivos dos investimentos? Qual fonte de financiamento?

\section{4- Vantagens Locais e Concorrência}

Quais as principais vantagens e o seu grau de importância que estão associadas a localização da empresa na região?

\begin{tabular}{|c|c|c|c|}
\hline Vantagens & $\begin{array}{l}\text { Muito } \\
\text { Importante }\end{array}$ & $\begin{array}{l}\text { Pouco } \\
\text { Importante }\end{array}$ & $\begin{array}{l}\text { Sem } \\
\text { importância }\end{array}$ \\
\hline \multicolumn{4}{|l|}{ 1. Infra-estrutura disponível } \\
\hline \multicolumn{4}{|l|}{$\begin{array}{l}\text { 2. Disponibilidade de mão de obra } \\
\text { qualificada }\end{array}$} \\
\hline \multicolumn{4}{|l|}{ 3. Custo da mão-de-obra } \\
\hline \multicolumn{4}{|l|}{$\begin{array}{l}\text { 4. Existência de programas de apoio e } \\
\text { promoção }\end{array}$} \\
\hline \multicolumn{4}{|l|}{$\begin{array}{l}\text { 5. Proximidade com universidades, } \\
\text { centros de pesquisa e apoio }\end{array}$} \\
\hline \multicolumn{4}{|l|}{$\begin{array}{l}\text { 6. Possibilidade de subcontratação de } \\
\text { atividades }\end{array}$} \\
\hline \multicolumn{4}{|l|}{ 7. Proximidade do mercado consumidor } \\
\hline \multicolumn{4}{|l|}{$\begin{array}{l}\text { 8. Existência de um pólo de software já } \\
\text { consolidado }\end{array}$} \\
\hline \multicolumn{4}{|l|}{ 9. Cultura Local } \\
\hline $\begin{array}{l}\text { 10.Outros.Qual? } \ldots \ldots \ldots \ldots \ldots \ldots \ldots \ldots \ldots \ldots \ldots \ldots \ldots \ldots \ldots \ldots \ldots \ldots \ldots \ldots \\
\ldots \ldots \ldots \ldots\end{array}$ & & & \\
\hline \multicolumn{4}{|c|}{ Faça um breve comentário sobre as vantagens locais assinaladas: } \\
\hline
\end{tabular}


Vantagens associadas à mão de obra local:

\begin{tabular}{|l|l|l|l|}
\hline Vantagens & $\begin{array}{l}\text { Muito } \\
\text { Importante }\end{array}$ & $\begin{array}{l}\text { Pouco } \\
\text { Importante }\end{array}$ & $\begin{array}{l}\text { Sem } \\
\text { importância }\end{array}$ \\
\hline $\begin{array}{l}\text { Fundamental e Médio } \\
\text { Escolaridade formal de Ensino }\end{array}$ & & & \\
\hline 2. Escolaridade de Nível Técnico & & & \\
\hline 3. Escolaridade de Nível Superior & & & \\
\hline 4. Disciplina & & & \\
\hline 5. Iniciativa para a resolução de problemas & & \\
\hline 6. Capacidade de aprendizado & & \\
\hline $\begin{array}{l}\text { Outros } \\
\text { Qual?............................................. }\end{array}$ & & \\
\hline Comente sobre as vantagens de mão de obra local: & & \\
\end{tabular}

Para a empresa, a proximidade geográfica com outras empresas do mesmo setor, facilita a transmissão de novos conhecimentos ?
( ) Sim
De que forma?:
( ) Não

\section{6- Políticas Públicas}

A empresa participa ou já participou de algum programa específico para o setor, promovido por diferentes esferas governamentais?
( ) $\operatorname{Sim}$ Qual(is):
( ) Não Motivo:

Caso tenha participado, mencione os benefícios:

Quais políticas públicas poderiam contribuir para o aumento da eficiência competitiva da empresa? 
Se por razões próprias do seu setor ou tipo de atividade, este questionário tenha deixado de captar aspectos que você considera relevante para a empresa, por favor, utilize este espaço, caso queira fazer algum comentário.

Muito obrigada pelo seu tempo e contribuição! 